
Front Cover - Golden tickseed (Coreopsis tinctoria), also known as Calliopsis or Plains coreopsis, is a native species in the sunflower family. It has potential for use in cultivated gardens and often appears in naturalized prairie, in meadow plantings, and along roadsides. An annual forb that usually germinates in late summer or fall, it overwinters as a rosette (round, low-growing group of leaves). In spring, stems begin branching and can grow to a height of 4 feet. The opposite leaves are deeply divided, with the upper leaf segments being very narrow. Flowering heads are numerous, 1-2 inches in diameter, and are yellow with a red-brown center. The species thrives in most of the United States and grows best in full sun on well-drained soil. Natural stands generally are found in bottomland areas with ample moisture. This year's cover photograph was made in SRS's B-Area by Ginger Humphries of Savannah River Nuclear Solutions' Regulatory Integration \& Environmental Services Department. The cover was designed by Eleanor Justice of the company's Records and Document Control Information Section - Information Management and Program Support Group.

For more information about this report, or to obtain additional copies, contact

R.L. Fanning

Environmental Monitoring Services

Savannah River Nuclear Solutions

Building 735-B

Aiken, SC 29808

Telephone: 803-952-8247

E-mail address: $\underline{\text { ross.fanning@srs.gov }}$

This document was prepared in conjunction with work accomplished under Contract No. DE-AC0908SR22470 with the U.S. Department of Energy. This work was conducted under an agreement with, and funded by, the U.S. Government. Neither the U.S. Government nor its employees, nor any of its contractors or subcontractors or their employees, makes any expressed or implied (1) warranty or assumes any legal liability for the accuracy or completeness-or for the use or results of such use-of any information, product, or process disclosed; or (2) representation that such use or results of such use would not infringe on privately owned rights; or (3) endorsement or recommendation of any specifically identified commercial product, process, or service. Any views and opinions of authors expressed in this document do not necessarily state or reflect those of the U.S. Government, or of its contractors or subcontractors. 


\section{Can We Make This Report More Useful to You?}

We want to make the Savannah River Site Environmental Report more useful to its readers. Please take a few minutes to let us know if the report meets your needs. Then fold and tape this page so the postage-paid notation and the mailing address are visible, and place it in the mail.

1. How do you use the Savannah River Site Environmental Report?

$\square$ to learn general information about the Savannah River Site

to learn about doses received for the current year

to learn about site compliance information

to gather effluent data

$\square$ to gather environmental surveillance data

other

2. What part(s) of this report do you use?

$\square$ main report

$\square$ data tables

3. Does the Savannah River Site Environmental Report contain

enough detail?

too much detail? For example,

too little detail? For example,

4. Is this report

too technical?

about right technically?

not technical enough?

5. If you could change this report to make it more readable and useful to you, what would you change?

6. What is your affiliation?

\begin{tabular}{|l|l|}
$\square$ & $\begin{array}{l}\text { DOE Headquarters } \\
\text { other DOE facility }\end{array}$ \\
$\square$ regulator & $\square$ universitylacademy \\
$\square$ other government officelagency & $\square$ media \\
\hline $\begin{array}{l}\text { environmental group } \\
\text { elected official }\end{array}$ & $\square$ industry \\
\hline other group \\
\hline other individual
\end{tabular}

7. To help us identify our audience, please indicate your educational background.

$\square$ graduate degree in scientific field

$\square$ graduate degree in nonscientific field

undergraduate degree in scientific field

undergraduate degree in nonscientific field

experience with science outside college setting

little or no scientific background

If you are interested in attending a workshop to critique the 2008 report, please provide your name, address, and telephone number.

For more information, please call R.L. Fanning, Manager - Environmental Monitoring Services, at 803-952-8247, or send an e-mail message to ross.fanning@srs.gov. 
POSTAGE WILL BE PAID BY ADDRESSEE

Attn: R.L. Fanning

Savannah River Nuclear Solutions

Building 735-B, Savannah River Site

Aiken, SC 29808-0001 


\section{Savannah River Site}

\section{Environmental Report for 2008}

Editor

Albert R. Mamatey
Technical Consultant

Timothy Jannik

Prepared by:

Savannah River Nuclear Solutions, LLC

Savannah River Site

Aiken, SC 29808

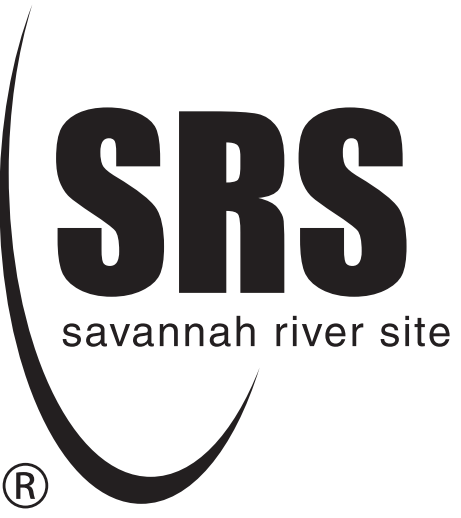





\section{Acknowledgements}

- The editor acknowledges with deep appreciation the efforts of the following individuals, who (in addition to the chapter authors, contributors, and compilers) conducted reviews for-and/or provided valuable resources, information, or technical data to - the Savannah River Site Environmental Report for 2008:

$\begin{array}{llll}\text { Le Anne Barkley } & \text { Paul Johns } & \text { Ken McLeod } & \text { Jeff Ross } \\ \text { Maureen Bernard } & \text { Rick Kelley } & \text { Jessie Melton } & \text { Ben Terry } \\ \text { Dean Campbell } & \text { Larry Koffman } & \text { Linda Nass } & \text { Jeff Thibault } \\ \text { Tiajuana Cochnauer } & \text { Walt Kubilius } & \text { Ross Natoli } & \text { Rob Turner } \\ \text { Brian Culligan } & \text { David Lee } & \text { Eric Nelson } & \text { Robin Utsey } \\ \text { Joe Dixon } & \text { Linda Lee } & \text { Lisa Oliver } & \text { Julie Wilson } \\ \text { Angela Emmons } & \text { Mary Beth Lloyd } & \text { Mike Phillips } & \text { David Yannitell } \\ \text { Don Faison } & \text { Donna K. Martin } & \text { Fran Poda } & \\ \text { Chuck Hunter } & \text { Sherrod Maxwell } & \text { Scott Ray } & \end{array}$

Clemson University Environmental Engineering/Earth Sciences Department Technical Reviewers:

Dr. Timothy A. DeVol - Professor

Dr. Robert A. Fjeld - Dempsey Professor of Waste Management

Dr. Fred J. Moltz, III - Research Professor/Distinguished Scientist Emeritus

Dr. Thomas J. Overcamp - Professor

- Listed below are those who provided expert publications support:
Kaye Atkins
Eleanor Justice
Lisa McCullough
Joan Toole

Duane Hoepker

- A special thanks to Gail Whitney for coordinating the DOE-SR review and approval process, which requires dedication and support from both DOE-SR and SRNS:

$\begin{array}{llll}\begin{array}{l}\text { Mary Baranek } \\ \text { (DOE-SR) }\end{array} & \begin{array}{l}\text { James Guisti } \\ \text { (DOE-SR) }\end{array} & \begin{array}{l}\text { Lee Gulledge } \\ \text { (SRNS) }\end{array} & \begin{array}{l}\text { Kevin Schmidt } \\ \text { (SRNS) }\end{array} \\ \text { Jim Bolen } & \text { Sherry Southern } & \text { Travis Moyer } & \text { Reggie Waltz } \\ \text { (DOE-SR) } & \text { (DOE-SR) } & \text { (SRNS) } & \text { (SRNS) } \\ \text { Amy Caver } & & \text { Chris Rodrigues } & \\ \text { (DOE-SR) } & & \text { (SRNS) } & \end{array}$

- Thanks to Chuck Harvel, Donnie Tucker, and Ray Wilcauskas for providing computer hardware and software support.

- Marvin Stewart is acknowledged with appreciation for providing Internet expertise and computer software support. 
- Gratitude is expressed to the following for management, administrative, field, and other support:

Brenda Alejo

Perry Allen

Rob Backer

Phil Baker

Jackie Banks

Lydia Bates

Sammie Baughman

Julie Bean

Mary Berry

Connie Black

Nancy Brown

Mike Burroughs

Will Callicott

Kim Cauthen

Joy Chapman

Sharon Chapman

Becky Chavous

Ken Cheeks

Vanessa Cofer
Gene Cooke

Roslyn Cooke

Sharon Crawford

Janet Curtis

Karl Damon

Libby Danielowich

Daryl Doman

Dale Duke

Ross Fanning

Richard Farr

Mary Flora

Lyman Fogle

Rodney Gantt

Lisa Gillespie

Brenda Goff

Mike Griffith

Calvin Hamilton

Tim Hartley

Jim Heffner
Jack Herrington

Minnie Hightower

Mike Hughes

David Hughey

Jeannette Hyatt

Rosa Jackson

Kevin Kostelnik

Brantley Kuglar

Bill Lewis

Cheryl Lewis

Bill Macky

Owen Mason

Janet McClearen

Tony Melton

Grace Miller

Ken Mishoe

Ann Odom

David Palmer

Karen Palmer
Wayne Pippen

Christine Posey

Thomasina Robinson

Jackie Rourk

Dennis Ryan

Eloy Saldivar

Debra Shea

Allan Sikes

Mark Spires

Jim Stafford

David Stevens

Dan Stewart

Becky Sturdivant

John Vaughn

Robin Wainwright

Kelly Way

Mtesa Wright

Tommy Young

Shealy Environmental

- We acknowledge our late friend and colleague, Pete Fledderman, who passed away October 5, 2008, for devoting nearly 20 years of his life to the annual SRS Environmental Report, for sharing with all of us his remarkable expertise in the environmental arena, and for his unwavering support of our efforts to produce a quality document for the site. 


\section{To Our Readers}
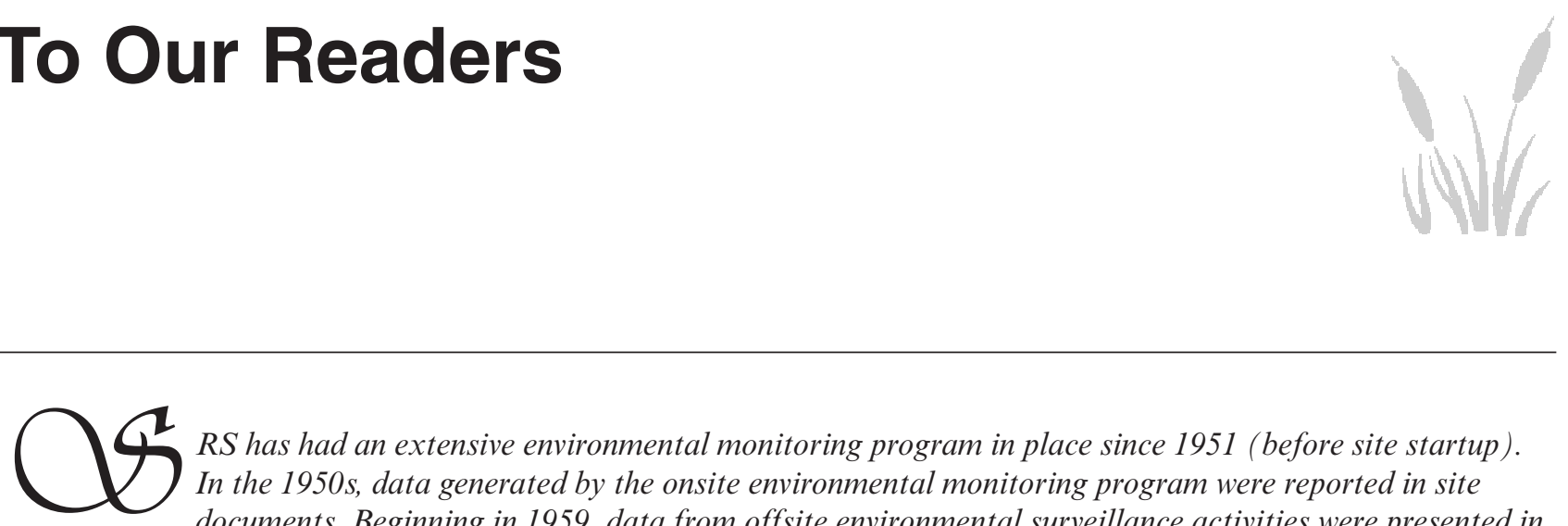

$R S$ has had an extensive environmental monitoring program in place since 1951 (before site startup).

In the 1950s, data generated by the onsite environmental monitoring program were reported in site documents. Beginning in 1959, data from offsite environmental surveillance activities were presented in reports issued for public dissemination. SRS reported onsite and offsite environmental monitoring activities separately until 1985, when data from both programs were merged into one public document.

The Savannah River Site Environmental Report for 2008 (SRNS-STI-2009-00190) is an overview of effluent monitoring and environmental surveillance activities conducted on and in the vicinity of SRS from January 1 through December 31, 2008-including the site's performance against applicable standards and requirements. Details are provided on major programs such as self-assessments, the Environmental Management System (EMS), and permit compliance. Information for the 2008 report was compiled and prepared by the Environmental Protection Section (EPS) of Washington Savannah River Company (WSRC) from January 1 until August 1, when the Regulatory Integration \& Environmental Services Department assumed these responsibilities as part of Savannah River Nuclear Solutions (SRNS), the site's new M\&O contractor. The "SRS Environmental Monitoring Plan" (WSRC-3Q1-2-1002) and the "SRS Environmental Monitoring Program" (WSRC-3Q1-2-1100) provide complete program descriptions and document the rationale and design criteria for the monitoring program, the frequency of monitoring and analysis, the specific analytical and sampling procedures, and the quality assurance requirements.

Complete data tables are included on the $\mathrm{CD}$ inside the back cover of this report. The CD also features (1) an electronic version of the report; (2) an appendix of site, environmental sampling location, dose, and groundwater maps; and (3) annual (2008) reports from a number of other SRS organizations. The data tables generally are presented as unformatted Excel spreadsheets; they are not intended to be printed. However, if printing is desired, the user can modify the "Page Setup" parameters in Excel as needed. If printing of the "SRS Maps" on the CD is desired, it is recommended (to ensure clarity) that figures 1-24 be printed $8.5 \times 11$ inches; figures $25-33,36 \times 32$ inches; and figure 34, 17x11 inches.

The following information should aid the reader in interpreting data in this report:

- Variations in environmental report data reflect year-to-year changes in the routine monitoring program, as well as occasional difficulties in sample collection or analysis. Examples of such difficulties include adverse environmental conditions (such as flooding or drought), sampling or analytical equipment malfunctions, sample handling and transportation issues, compromise of the samples in the preparation laboratories or counting room.

- Table heading abbreviations may include the following: (1) "N" is number of observations; (2) "SampleCon" is sample concentration; (3) "SampleStd" is standard deviation; and (4) "Sig" is significance.

- Analytical results and their corresponding uncertainty terms generally are reported with up to three significant figures. This is a function of the computer software used and may imply greater accuracy in the reported results than the analyses would allow. 
- Units of measure and their abbreviations are defined in the glossary (beginning on page G-1) and in charts at the back of the report. The reported uncertainty of a single measurement reflects only the counting error-not other components of random and systematic error in the measurement process - so some results may imply a greater confidence than the determination would suggest.

- An uncertainty quoted with a mean value represents the standard deviation of the mean value. This number is calculated from the uncertainties of the individual results. For an unweighted mean value, the uncertainty is the sum of the variances for the individual values divided by the number of individual results squared. For a weighted mean value, the uncertainty is the sum of the weighted variances for the individual values divided by the square of the sum of the weights.

- All values represent the weighted average of all acceptable analyses of a sample for a particular analyte. Samples may have undergone multiple analyses for quality assurance purposes or to determine if radionuclides are present. For certain radionuclides, quantifiable concentrations may be below the minimum detectable activity of the analysis, in which case the actual concentration value is presented to satisfy DOE reporting guidelines.

- The generic term "dose," as used in the report, refers to the committed effective dose equivalent (50-year committed dose) from internal deposition of radionuclides and to the effective dose equivalent attributable to beta/gamma radiation from sources external to the body.

\section{Report Available on Web}

Readers can find the SRS Environmental Report on the World Wide Web at the following address: http://www.srs.gov/general/pubs/ERsum/index.html. 


\section{Contents}

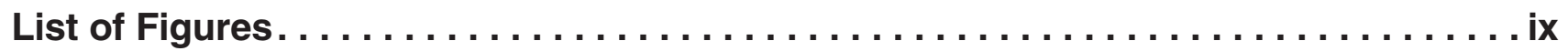

List of Tables. . . . . . . . . . . . . . . . . . . .

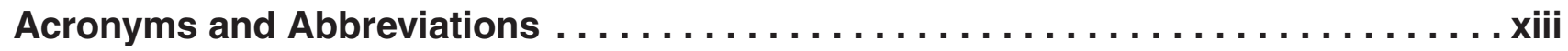

Sampling Location Information. . . . . . . . . . . . . . . . . . . . .

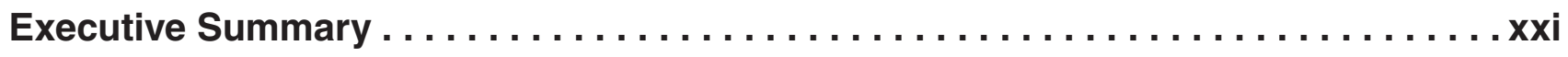

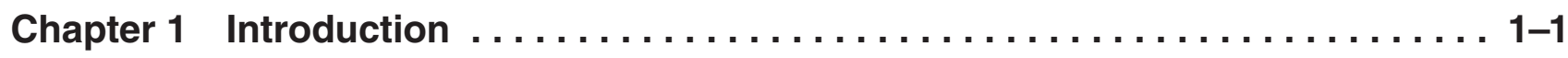

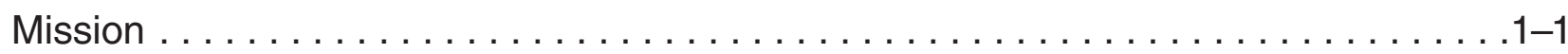

Site Location, Demographics and Environment $\ldots \ldots \ldots \ldots \ldots \ldots \ldots \ldots \ldots \ldots \ldots \ldots \ldots$

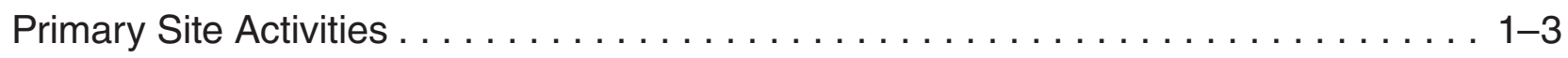

Chapter 2 Environmental Management System .................

Environmental Management System Policy . . . . . . . . . . . . . . . 2-2

Chapter 3 Environmental Compliance...................... 3-1

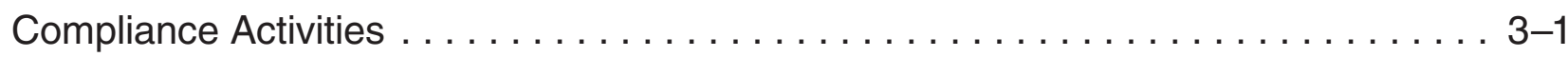

Environmental Release Response and Reporting $\ldots \ldots \ldots \ldots \ldots \ldots \ldots \ldots$ 3-16

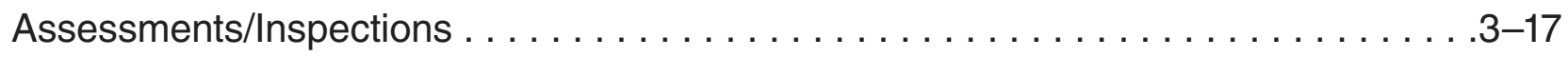

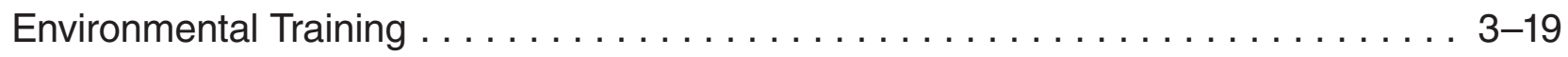

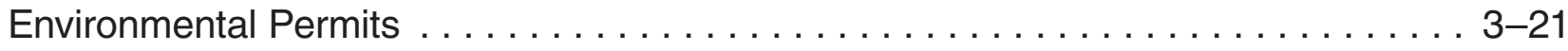

Chapter 4 Effluent Monitoring. ......................

Radiological Monitoring. . . . . . . . . . . . . .

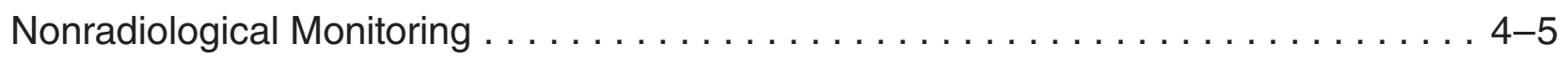

Chapter 5 Environmental Surveillance. .................... 5-1

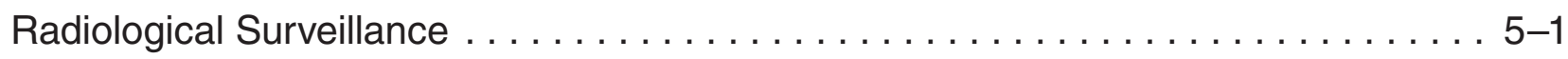

Nonradiological Surveillance. . . . . . . . . . . . . . . . . . . . .

Environmental Report for 2008 (SRNS-STI-2009-00190) vii 
Chapter 6 Potential Radiation Doses.......................

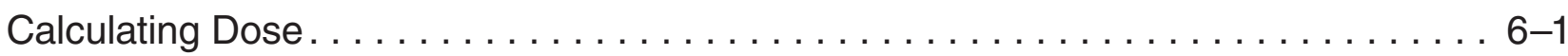

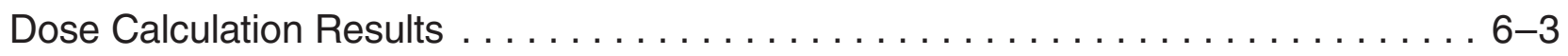

Chapter 7 Groundwater..........................

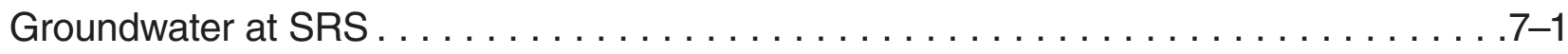

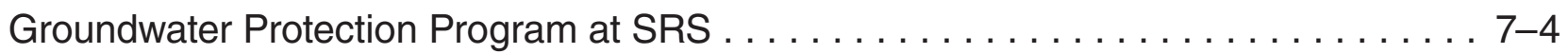

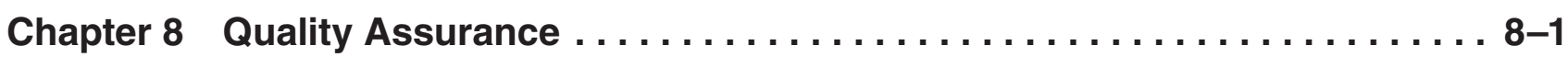

SRS and Environmental QA Programs Integration $\ldots \ldots \ldots \ldots \ldots \ldots \ldots$ 8-1

QA for EM Program Samples . . . . . . . . . . . . . . .

QA for EML Sample Analyses. . . . . . . . . . . . . . . . .

QA for EM Sample Analyses. . . . . . . . . . . . . . . .

Appendix A Applicable Guidelines, Standards, and Regulations.......... A-1

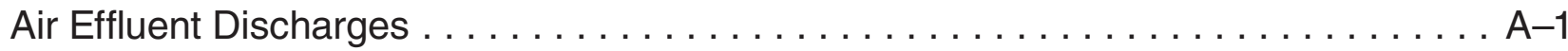

(Process) Liquid Effluent Discharges $\ldots \ldots \ldots \ldots \ldots \ldots \ldots \ldots \ldots \ldots \ldots \ldots \ldots \ldots \ldots$

Site Streams . . . . . . . . . . . . . .

Savannah River. .......................... A-4

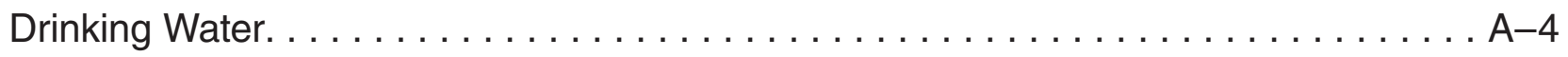

Groundwater .........................

Potential Doses. . . . . . . . . . . . . . . . . . . . . . A

Environmental Management . . . . . . . . . . . . . . . . . . A 8

Quality Assurance/Quality Control . . . . . . . . . . . . . . . . A -8

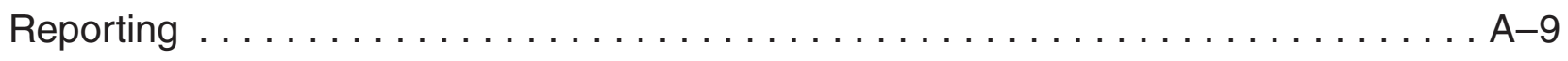

Appendix B Radionuclide and Chemical Nomenclature $\ldots \ldots \ldots \ldots \ldots \ldots$ B-1

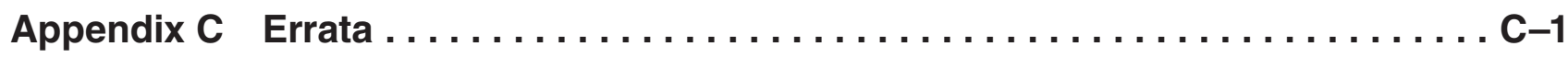

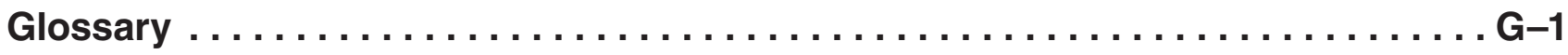

References $\ldots \ldots \ldots \ldots \ldots \ldots \ldots \ldots \ldots \ldots \ldots \ldots \ldots \ldots \ldots \ldots \ldots \ldots, \mathbf{R}-\mathbf{1}$ 


\section{List of Figures}

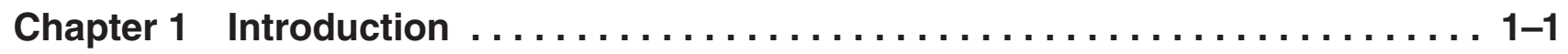

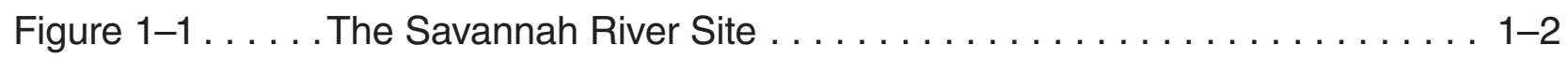

Chapter 4 Effluent Monitoring. $\ldots \ldots \ldots \ldots \ldots \ldots \ldots \ldots \ldots \ldots \ldots \ldots \ldots \ldots$ 4-1

Figure 4-1 . . . . . Ten-Year History of SRS Annual Atmospheric Tritium Release . . . 4-2

Figure 4-2. . . . . Ten-Year History of Direct Releases of Tritium to SRS Streams . . 4-4

Chapter 5 Environmental Surveillance. .................. 5-1

Figure $5-1 \ldots$. . Tritium from SRS Seepage Basins and SWDF to Site Streams,

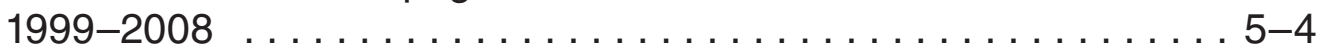

Figure $5-2 \ldots \ldots$ SRS Tritium Transport Summary, $1960-2008 \ldots \ldots \ldots \ldots \ldots$. . . . . .

Chapter 6 Potential Radiation Doses . . . . . . . . . . . . . . . . . 6 6

Figure 6-1 . . . . . Ten-Year History of SRS Maximum Potential All-Pathway Doses. . 6-8

Figure 6-2. . . . . Ten-Year History of SRS Creek-Mouth Fisherman's Doses . . . . . 6-11

Chapter 7 Groundwater..................

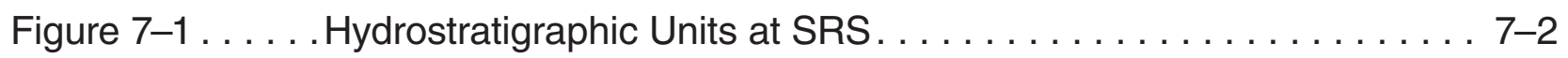

Figure $7-2 \ldots \ldots$ Groundwater at SRS $\ldots \ldots \ldots \ldots \ldots \ldots \ldots \ldots \ldots \ldots \ldots \ldots \ldots \ldots$

Appendix A Applicable Guidelines, Standards, and Regulations.......... A-1

Figure A-1 . . . SRS EM Program QA Document Hierarchy . . . . . . . . . A A-10 



\section{List of Tables}

Chapter 3 Environmental Compliance...................... 3-1

Table $3-1 \ldots$. Laws/Regulations Applicable to SRS . . . . . . . . . . . . 3-2

Table 3-2 . . . . . SRS Reporting Requirements under "Federal Compliance with

Right-to-Know Laws and Pollution Prevention Requirements"

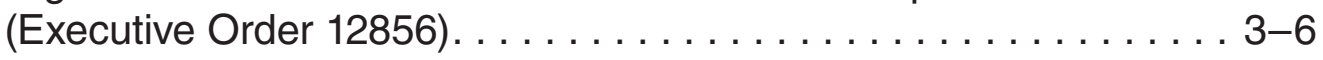

Table 3-3 . . . . Summary of SRS-Related NEPA Reviews in $2008 \ldots \ldots \ldots \ldots$. . . . .

Table 3-4 . . . . . SRS Construction and Operating Permits, 2004-2008 . . . . . . 3-20

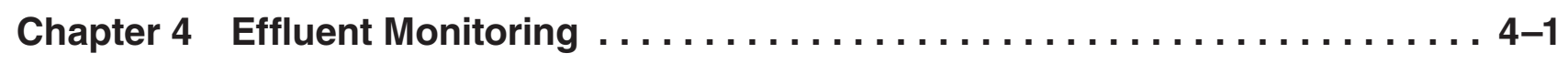

Table 4-1 . . . . SRS Estimated SCDHEC Standard 2 Pollutant Air Emissions,

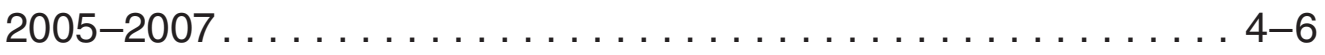

Table $4-2 \ldots \ldots$ SRS Power Plant Boiler Capacities $\ldots \ldots \ldots \ldots \ldots \ldots \ldots$ 4 4 .7

Table 4-3 . . . . 2008 Boiler Stack Test Results. . . . . . . . . . . . . . . . . . 4-7

Table 4-4 . . . . 2008 Exceptions to SCDHEC-Issued NPDES Permit Liquid Discharge Limits at SRS . . . . . . . . . . . . . 4-9

Chapter 6 Potential Radiation Doses....................... 6-1

Table 6-1 . . . . 2008 Radioactive Liquid Release Source Term and 12-Month Average Downriver Radionuclide Concentrations Compared to EPA's Drinking Water Maximum Contaminant Levels (MCLs) . . . . 6-4

Table 6-2 . . . . Potential Dose to the Maximally Exposed Individual from SRS Liquid Releases in $2008 \ldots \ldots \ldots \ldots \ldots \ldots \ldots \ldots \ldots \ldots \ldots$

Table 6-3 . . . . . Potential Dose to the Maximally Exposed Individual from SRS

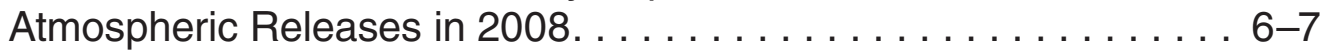

Table 6-4 . . . . 2008 Maximum Potential All-Pathway and Sportsman Doses Compared to the DOE All-Pathway Dose Standard . . . . . . . . . 6-9

Table 6-5 . . . . Potential Lifetime Risks from the Consumption of Savannah River

Fish Compared to Dose Standards . . . . . . . . . . . . . . 6-12 
Chapter 7 Groundwater. $.7-1$

Table 7-1 . .... Summary of Maximum Well Monitoring Results for Major Areas Within SRS, 2007-2008. . . . . . . . . . . . . . 7-9

Chapter 8 Quality Assurance $\ldots \ldots \ldots \ldots \ldots \ldots \ldots \ldots \ldots \ldots \ldots \ldots$ 8-1

Table 8-1 . . . . EML Performance on Mixed-Analyte Performance Evaluation Program (MAPEP) . . . . . . . . . . . . .

Table 8-2 . . . . . Subcontract-Laboratory Percent Acceptable Performance for Environmental Resource Associates (ERA) Water Pollution Studies . . . . . . . . . . . . . . . . . . . . . 8-5

Table 8-3 . . . . . Subcontract-Laboratory Performance on Mixed-Analyte Performance Evaluation Program (MAPEP) . . . . . . . . . 8-6

Table 8-4 . . . . . Subcontract-Laboratory Performance MAPEP Letters of Concern. . 8-7 Appendix A Applicable Guidelines, Standards, and Regulations......... A-1 Table A $-1 \ldots$. Criteria Air Pollutant Standards . . . . . . . . . . . . . A-2 Table A-2 . . . . A Airborne Emission Limits for SRS Coal-Fired Boilers. . . . . . . . . A-3 Table A-3 . . . . . Airborne Emission Limits for SRS Fuel Oil-Fired Package Boilers . . A-3 Table A-4 . . . . . Airborne Emission Limits for SRS 784-7A Biomass Boiler. . . . . . . A-4 Table A-5 . . . . . Airborne Emission Limits for SRS 784-7A Oil-Fired Package Boiler. . . . . . . . . . . . . . . . . . A-4

Table A-6 . . . . South Carolina Water Quality Standards for Freshwaters . . . . . . A-5 


\section{Acronyms and Abbreviations}

Note: Sampling location abbreviations can be found on page xix.

A

ACP - Area Completion Projects

ACM - Asbestos containing material

ALARA - As low as reasonably achievable

ANSI - American National Standards Institute

ANS - Academy of Natural Sciences

AOP - Annual Operational Plan

B

BAT - Best Available Technology

BCG - Biota concentration guide

BE - Biological Evaluation

BGN - Burial Ground North

bgs - Below ground surface

BJWSA - Beaufort-Jasper Water and Sewer Authority

BMP - Best Management Practice

BTU - British Thermal Unit

CAA - Clean Air Act

CAAA - Clean Air Act Amendments of 1990

CAB - Citizens Advisory Board

CAS - Chemical abstract numbers

CAT - Consolidated Annual Training

CD - Compact disk
C\&D - Construction and Demolition

CDC - Centers for Disease Control and Prevention

CEI - Compliance Evaluation Inspection

CERCLA - Comprehensive Environmental Response, Compensation, and Liability Act (Superfund)

CFC - Chlorofluorocarbon

CFR - Code of Federal Regulations

Ci - Curie

CME - Comprehensive Monitoring Evaluation

CMIR - Corrective Measures Implementation Report

CMP - Chemicals, metals, and pesticides

CSRA - Central Savannah River Area

CWA - Clean Water Act

D\&D - Deactivation and decommissioning DCG - Derived concentration guide

DOE - U.S. Department of Energy

DOECAP - Department of Energy Consolidated Audit Program

DOE/EML - U.S. Department of Energy/Environmental Measurements Laboratory

DOE-HQ - U.S. Department of Energy-Headquarters 
DOE-SR - U.S. Department of Energy-Savannah River Operations Office

DMWE - Data Management and Waste Engineering

DMR - Discharge Monitoring Report

DWS - Drinking water standards

EA - Environmental assessment

EEC - Environment evaluation checklist

EIS - Environmental impact statement

EM - Environmental Monitoring

EMCAP - Environmental Management Consolidated Audit Program

EML - Environmental Monitoring Lab

EMS - Environmental Management System

EO - Executive Order

EPA - U.S. Environmental Protection Agency

EPCRA - Emergency Planning and Community Rightto-Know Act

EPS - Environmental Protection Section

ERA - Environmental Resource Associates

ESD - Explanation of Significant Difference

ESA - Endangered Species Act

ESEC - Environmental Science Educator's Cooperative

ESS - Environmental Services Section

FDA - Food and Drug Administration

FEB - Facility Evaluation Board

FEMP - Federal Energy Management Program

FFA - Federal Facility Agreement
FFCA - Federal Facility Compliance Agreement

FFCAct - Federal Facility Compliance Act

FIFRA - Federal Insecticide, Fungicide, and Rodenticide Act

FIMS - Flow injection mercury system

FONSI - Finding of no significant impact

FTF - F-Area Tank Farm

GS-MS - Inductively coupled plasma atomic emission spectrometry

GDNR - Georgia Department of Natural Resources

GET - General employee training

GNEP - Global Nuclear Energy Partnership

GSMP - Groundwater Surveillance Monitoring Program

GSA - General Separations Area

GTCC - Greater Than Class C

Gy - Gray

HBFC - Hydrobromofluorocarbon

HCFC - Hydrochlorofluorocarbon

HTF - H-Area Tank Farm

IA - Interim Action

IAPCR - Interim Action Post Closure Report

ICP-AES - Inductively coupled plasma atomic emission spectrometry

ICP-MS - Inductively coupled plasma mass spectrometry

ICRP - International Commission on Radiological Protection 
I\&SD - Infrastructure and Services Department
ISMS - Integrated Safety Management System
ISO - International Organization for Standardization

$\gamma \mathbf{k g}-$ Kilogram

LDR - Land disposal restrictions

LLW - Low-level radioactive waste

M\&O - Management and Operating

MACT - Maximum achievable control technology

MAPEP - Mixed Analyte Performance Evaluation Program

$\mathbf{m C i}$ - Millicurie

MCL - Maximum contaminant level

MDC - Minimum detectable concentration

MFFF - Mixed Oxide Fuel Fabrication Facility

Mg/L - Milligrams per liter

mL - Milliliter

MOA - Memoranda of agreement

MOX - Mixed oxide

mrem - Millirem

mSv - Millisievert

NBN - No building number

NDAA - National Defense Authorization Act

NEPA - National Environmental Policy Act

NESHAP - National Emission Standards for Hazardous Air Pollutants
NHPA - National Historic Preservation Act

NOV - Notice of violation

NPDES - National Pollutant Discharge Elimination System

NRC - Nuclear Regulatory Commission

NRMP - Natural Resources Management Plan

NWP - Nationwide permit

O

ODS - Ozone-depleting substance

OFI - Opportunity for improvement

D P2 - Pollution prevention program

PA - Performance assessment

PAR - Pesticide Activity Report

PCB - Polychlorinated biphenyl

PCR - Post-construction report

pCi/L - Picocuries per liter

PEIS - Programmatic environmental impact statement

PM - Particulate matter

$\mathbf{p H}$ - Measure of the hydrogen ion concentration in an aqueous solution (acidic solutions, $\mathrm{pH}$ from $0-6$; basic solutions, $\mathrm{pH}>7$; and neutral solutions, $\mathrm{pH}=7$ )

POC - Points of contact

ppb - Parts per billion

ppm - Parts per million

PUREX - Plutonium Uranium Extraction Process

(AA - Quality assurance
QC - Quality control 
R

RACR - Remedial Action Completion Reports

RCRA - Resource Conservation and Recovery Act

RFI/RI - RCRA facility investigation/remedial investigation

RI\&ES - Regulatory Integration and Environmental Services

RHA - Rivers and Harbors Act

RM - River mile

RMP - Risk management plan

ROD - Record of decision

SA - Supplement analysis

SARA - Superfund Amendments and

Reauthorization Act

Savannah I\&D - Savannah Industrial and Domestic Water Supply Plant

SCDHEC - South Carolina Department of Health and Environmental Control

SDD - Site Deactivation and Decommissioning

SDWA - Safe Drinking Water Act

SE - Removal Site Evaluation

SEIS - Supplemental environmental impact statement

SES - Shealy Environmental Services, Inc.

SCE\&G - South Carolina Electric and Gas

SIRIM - Site Item Reportability and Issues Management

SLA - Service level agreement

SMU - Statement of mutual understanding

SRARP - Savannah River Archaeological Research Program

SREL - Savannah River Ecology Laboratory
S/RID - Standards/Requirements Identification Document

SRNL - Savannah River National Laboratory

SRNS - Savannah River Nuclear Solutions, LLC

SRS - Savannah River Site

STAR - Site Tracking, Analysis, and Reporting

STP - Site Treatment Plan

SWDF - Solid Waste Disposal Facility

TCLP - Toxicity characteristic leaching procedure

TEAM - Transformational Energy Action Management

TEM - Transmission electron microscopy

TES - Threatened and endangered species

TLD - Thermoluminescent dosimeter

TDS - Total dissolved solids

TRI - Toxic Release Inventory

TRU - Transuranic waste

TSCA - Toxic Substances Control Act

TSS - Total suspended solids

USFS-SR - U.S. Department of Agriculture Forest Service-Savannah River

$\boldsymbol{\mu g} / \mathbf{L}-$ Micrograms per liter

$\boldsymbol{\mu g} / \mathbf{m}^{3}-$ Micrograms per cubic meter

$\boldsymbol{\mu S} / \mathbf{c m}$ - Microsieverts per centimeter

USGS - U.S. Geological Survey

UST - Underground storage tank

UTM - Universal Transverse Mercator 
$\sqrt{7}$ VEGP - Vogtle Electric Generating Plant VOC - Volatile organic compound

WIPP - Waste Isolation Pilot Plant

W/Min - Waste minimization

WMAP - Waste Management Area Project

WP - Water pollution

WQC - Water quality certification

WS - Water supply

WSI-SRS - Wackenhut Services Incorporated-Savannah River Site

WSMS - Washington Safety Management Solutions

WSRC - Washington Savannah River Company 



\section{Sampling Location Information}

Note: This section contains sampling location abbreviations used in the text andlor on the sampling location maps. It also contains a list of sampling locations known by more than one name (see next page).

\begin{tabular}{|c|c|}
\hline Location Abbreviation & Location Name/Other Applicable Information \\
\hline $4 \mathrm{M}$ & Four Mile \\
\hline $4 \mathrm{MB}$ & Fourmile Branch (Four Mile Creek) \\
\hline $4 \mathrm{MC}$ & Four Mile Creek \\
\hline BDC & Beaver Dam Creek \\
\hline$B G$ & Burial Ground \\
\hline EAV & E-Area Vaults \\
\hline FM & Four Mile \\
\hline FMB & Fourmile Branch (Four Mile Creek) \\
\hline FMC & Four Mile Creek (Fourmile Branch) \\
\hline GAP & Georgia Power Company \\
\hline HP & HP (sampling location designation only; not an actual abbreviation) \\
\hline HWY & Highway \\
\hline KP & Kennedy Pond \\
\hline L3R & Lower Three Runs \\
\hline NRC & Nuclear Regulatory Commission \\
\hline NSB L\&D & New Savannah Bluff Lock \& Dam \\
\hline PAR & "P and R" Pond \\
\hline PB & Pen Branch \\
\hline PMR & Patterson Mill Road \\
\hline $\mathrm{RM}$ & River Mile \\
\hline SC & Steel Creek \\
\hline SWDF & Solid Waste Disposal Facility \\
\hline TB & Tims Branch \\
\hline TC & Tinker Creek \\
\hline TNX & Multipurpose Pilot Plant Campus \\
\hline U3R & Upper Three Runs \\
\hline VEGP & Vogtle Electric Generating Plant (Plant Vogtle) \\
\hline
\end{tabular}




\section{Sampling Locations Known by More Than One Name}

Augusta Lock and Dam; New Savannah Bluff Lock and Dam

Beaver Dam Creek; 400-D

Four Mile Creek-2B; Four Mile Creek at Road C

Four Mile Creek-3A; Four Mile Creek at Road C

Lower Three Runs-2; Lower Three Runs at Patterson Mill Road

Lower Three Runs-3; Lower Three Runs at Highway 125

Pen Branch-3; Pen Branch at Road A-13-2

R-Area downstream of $R-1 ; 100-R$

River Mile 118.8; U.S. Highway 301 Bridge Area; Highway 301; US 301

River Mile 129.1; Lower Three Runs Mouth

River Mile 141.5; Steel Creek Boat Ramp

River Mile 150.4; Vogtle Discharge

River Mile 152.1; Beaver Dam Creek Mouth

River Mile 157.2; Upper Three Runs Mouth

River Mile 160.0; Dernier Landing

Steel Creek at Road A; Steel Creek-4; Steel Creek-4 at Road A; Steel Creek at Highway 125

Tims Branch at Road C; Tims Branch-5

Tinker Creek at Kennedy Pond; Tinker Creek-1

Upper Three Runs-4; Upper Three Runs-4 at Road A; Upper Three Runs at Road A; Upper Three Runs at Road 125

Upper Three Runs-1A; Upper Three Runs-1A at Road 8-1

Upper Three Runs-3; Upper Three Runs at Road C 


\section{Executive Summary}

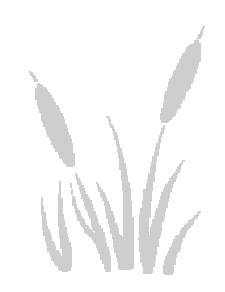

$\tau$

he Savannah River Site Environmental Report for 2008 (SRNS-STI-2009-00190) is prepared for the

U.S. Department of Energy (DOE) according to requirements of DOE Order 231.1 A, "Environment, Safety and Health Reporting," and DOE Order 5400.5, "Radiation Protection of the Public and Environment."

The annual SRS Environmental Report has been produced for more than 50 years. Several hundred copies are distributed each year to government officials, universities, public libraries, environmental and civic groups, news media, and interested individuals. The report's purpose is to

- present summary environmental data that characterize site environmental management performance

- confirm compliance with environmental standards and requirements

- highlight significant programs and efforts

\section{Minimal Impact}

SRS posted another exemplary environmental compliance record in 2008, as its operations continued to result in minimal impact to the offsite public and the surrounding environment. The site's radioactive and chemical discharges to air and water were well below regulatory standards for environmental and public health protection; its air and water quality met applicable requirements; and the potential radiation dose from its discharges was less than the national dose standards.

The largest radiation dose that an offsite, hypothetical, maximally exposed individual could have received from SRS operations during 2008 was estimated to be 0.12 millirem (mrem). (An mrem is a standard unit of measure for radiation exposure.) The 2008 SRS dose is just 0.12 percent of the DOE all-pathway dose standard of 100 mrem per year, and far less than the natural average dose of about 300 mrem per year (according to Report No. 160 of the National Council of Radiation Protection and Measurements) to people in the United States. The 2008 all-pathway dose was more than the 2007 dose of $0.10 \mathrm{mrem}$ - primarily because of the drought-influenced record low Savannah River flow rate during 2008, which resulted in less dilution.

\section{Extensive Monitoring; Documented Compliance}

Environmental monitoring is conducted extensively within a 2,000-square-mile network extending 25 miles from SRS, with some monitoring performed as far as 100 miles from the site. The area includes neighboring cities, towns, and counties in Georgia and South Carolina. Thousands of samples of air, rainwater, surface water, drinking water, groundwater, food products, wildlife, soil, sediment, and vegetation are collected by SRS and state authorities and analyzed for the presence of radioactive and nonradioactive contaminants.

Compliance with environmental regulations and with DOE orders related to environmental protection provides assurance that onsite processes do not impact the public or the environment adversely. Such compliance is documented in this report. 
SRS had a National Pollutant Discharge Elimination System (NPDES) compliance rate of 99.89 percent in 2008 , with only five of the 4,529 sample analyses performed exceeding permit limits. The NPDES program protects streams, reservoirs, and other wetlands by limiting the release of nonradiological pollution into surface waters. Discharge limits are set for each facility to ensure that SRS operations do not negatively impact aquatic life or degrade water quality.

\section{Three Notices of Violation}

Issued by the U.S. Environmental Protection Agency or the South Carolina Department of Health and
Environmental Control, Notices of Violation (NOVs) are the procedures that allege potential violations of an organization's permits or environmental laws or regulations. SRS received three allegations of violation in 2008 (two involving sanitary wastewater releases and one involving air emissions). The sanitary wastewater release allegations did not result in an administrative hearing to determine if a violation occurred. In 2008, the parties continued to negotiate a settlement of the air emissions release dispute, which is expected to be resolved by consent in early 2009. More detailed information on these NOVs appears in chapter 3 ("Environmental Compliance") of this report. 


\section{Introduction}

Timothy Jannik

Savannah River National Laboratory

Al Mamatey

Regulatory Integration \& Environmental Services

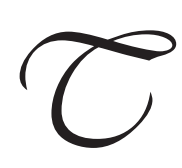

he Savannah River Site (SRS), one of the facilities in the U.S. Department of Energy (DOE)

complex, was constructed during the early 1950s to produce materials (primarily plutonium-239 and

tritium) used in nuclear weapons. The site covers approximately 310 square miles in South Carolina

and borders the Savannah River.

\section{Mission}

SRS's mission is to fulfill its responsibilities safely and securely in the stewardship of the nation's nuclear weapons stockpile, nuclear materials, and the environment. These stewardship areas reflect current and future missions to

- meet the needs of the U.S. nuclear weapons stockpile

- store, treat, and dispose of excess nuclear materials safely and securely

- treat and dispose of legacy radioactive liquid waste from the Cold War

- clean up radioactive and chemical environmental contamination from previous site operations

SRS continued in 2008 to improve environmental quality, clean up its legacy waste sites, manage any waste produced from current operations, and plan future operations. This included working with the South Carolina Department of Health and Environmental Control (SCDHEC), the Environmental Protection Agency (EPA), and the Nuclear Regulatory Commission to find mutually acceptable solutions for waste disposition. As part of its ongoing mission, the site will continue to address the highest risk waste management issues by working to safely dispose of liquid waste and surplus nuclear materials at offsite locations, and by safely stabilizing any waste tank residue.

\section{Site Location, Demographics, and Environment}

SRS covers 198,344 acres in Aiken, Allendale, and Barnwell counties of South Carolina. The site is approximately 12 miles south of Aiken, South Carolina, and 15 miles southeast of Augusta, Georgia (figure 1-1).

The average population density in the counties surrounding SRS is about 91 people per square mile, with the largest concentration in the Augusta metropolitan area. Based on 2000 U.S. Census Bureau data, the population within a 50 -mile radius of the center of SRS is approximately 712,780 .

\section{Water Resources}

SRS is bounded on its southwestern border by the Savannah River for about 35 river miles and is approximately 160 river miles from the Atlantic Ocean.

The Savannah River is used as a drinking water supply source for some residents upstream of SRS. The nearest downriver municipal drinking water source (Beaufort-Jasper Water and Sewer Authority's Purrysburg Water Treatment Plant) is located approximately 90 river miles from the site. The river also is used for commercial and sport fishing, boating, and other recreational activities. There are no known large-scale uses of the river for irrigation by farming operations downriver of the site. The groundwater flow system at SRS consists of four major aquifers. Groundwater generally migrates 


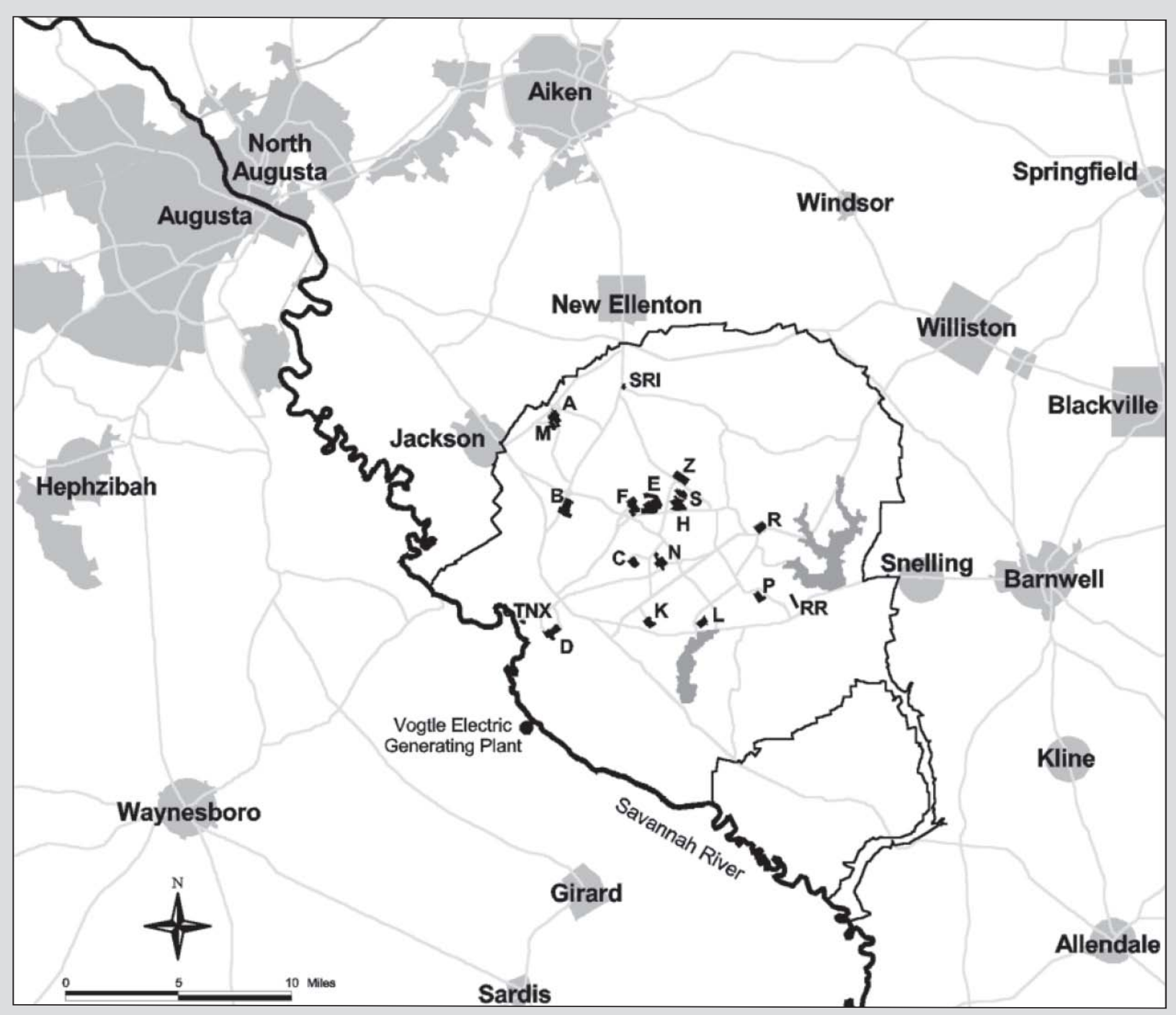

Figure 1-1 The Savannah River Site

SRNL Map

SRS is located in South Carolina, about 12 miles south of Aiken, South Carolina, and about 15 miles southeast of Augusta, Georgia. The Savannah River flows along a portion of the site's southwestern border. The capital letters within the SRS borders identify operations areas referenced throughout this report.

downward as well as laterally in recharge areaseventually either discharging into the Savannah River and its tributaries or migrating into the deeper regional flow system. SRS groundwater is used both for processes and for drinking water.

\section{Geology}

SRS is located on the southeastern Atlantic Coastal Plain, which is part of the larger Atlantic Plain that extends south from New Jersey to Florida. The center of SRS is approximately 25 miles southeast of the geological Fall Line that separates the Coastal Plain from the Piedmont.

\section{Land and Forest Resources}

About 90 percent of SRS land area consists of natural forests and managed pine plantations, which are planted, maintained, and harvested by the U.S. Department of Agriculture Forest Service-Savannah River. The site contains portions of three forest types: Oak-Hickory-Pine, Southern Mixed, and Southern Floodplain. More than 370 Carolina bays 
exist on SRS. These unique wetlands provide important habitat and refuge for many plants and animals.

\section{Animal and Plant Life}

The majority of SRS is undeveloped; only about 10 percent of the total land area is developed or used for industrial facilities. The remainder is maintained in healthy, diverse ecosystems. About 260 species of birds, 60 species of reptiles, 40 species of amphibians, 80 species of freshwater fish, and 50 species of mammals have been identified at SRS.

\section{Primary Site Activities}

\section{Liquid Waste Operations}

SRS continued to manage its Liquid Waste Operations facilities in support of the integrated high-activity waste removal program in 2008. This included continued operation of the Defense Waste Processing Facility, the Saltstone Production Facility, the F-Area and H-Area tank farms - with their three associated evaporators - and the startup and successful operation of the Actinide Removal Process/ Modular Caustic Side Solvent Extraction Unit salt processing facilities. A detailed description of the site's 2008 Liquid Waste Operations activities can be found on the $\mathrm{CD}$ accompanying this report.

\section{Separations}

In the past, the SRS separations facilities processed targets and fuel from SRS reactors to produce materials for nuclear weapons and isotopes for medical and NASA applications. Since the end of the Cold War in 1991, the mission of the facilities has shifted to stabilization of nuclear materials from onsite and offsite sources for safe storage or disposition. An important part of this mission is the conversion of weapons-usable highly enriched uranium to low-enriched uranium for use in the manufacture of commercial reactor fuel, a key component of the nation's nuclear nonproliferation program.

\section{Spent Nuclear Fuel Storage}

SRS's spent nuclear fuel facilities store fuel elements from a variety of foreign and domestic reactors. The mission of the spent nuclear fuel program is to cost-effectively eliminate the hazards associated with legacy spent nuclear fuel—from research reactors around the world - by receiving, stabilizing, and dispositioning the fuels in a safe and environmentally sound manner.

\section{Tritium Processing}

SRS tritium facilities extract tritium from absorber rods received from the Tennessee Valley Authority, and recycle tritium from nuclear weapons reservoirs that have been returned from service. This allows the United States to use its tritium supplies effectively and efficiently.

\section{Waste Management}

\section{SRS manages}

- the large volumes of radiological and nonradiological waste created by previous operations of the nuclear reactors and their support facilities

- newly generated waste created by ongoing site operations

Although the primary focus is on safely managing the radioactive liquid waste, the site also must handle, store, treat, dispose of, and minimize solid waste resulting from past, ongoing, and future operations. Solid waste includes hazardous, lowlevel, mixed, sanitary, and transuranic wastes. More information about radioactive liquid and solid wastes is included on the CD housed inside the back cover of this report.

\section{Area Completion Projects}

SRS's Soil and Groundwater Closure Projects and Site Deactivation and Decommissioning organizations merged in 2008 to create Area Completion Projects (ACP). ACP personnel are responsible for the remediation of SRS inactive waste sites and contaminated groundwater to reduce risk and to protect human health and the environment. At the end of 2008,360 of the 515 known waste units were complete, 142 were in the assessment phase, and 13 were in the remediation phase.

The remediation is regulated under the Comprehensive Environmental Response, Compensation, and Liability Act (CERCLA) and the Resource Conservation and Recovery Act (RCRA). This is accomplished through the SRS Federal Facility Agreement (FFA) [FFA, 1993], a tri-party agreement between 
EPA, SCDHEC, and DOE. The FFA provides guidelines that

- govern the remedial process that DOE-SR follows to ensure the investigation and remediation of waste units that pose an unacceptable risk.

- ensure that SRS satisfies RCRA and CERCLA requirements

- include cleanup schedules for SRS waste units

During 2008, ACP contributed to a number of initiatives that support SRS cleanup, including (1) final closure of the highest-risk waste unit in the environmental remediation program - the General Separations Area Consolidation Unit - which consisted of seven waste subunits, including the 76-acre Old Radioactive Waste Burial Ground; (2) successful removal of more than 45,900 pounds of Dense Nonaqueous Phase Liquid through Dynamic Underground Stripping (bringing the total removed by this process to approximately 427,000 pounds), which began operations at M-Area in August 2005; (3) the in-situ end state agreement between SCDHEC, EPA, and DOE for both the R and P reactor areas; and (4) the removal of more than 4,000 depleted uranium oxide drums from R-Area, which allowed the final assessment and closure of the R-Area Operable Unit to get under way.

More information about ACP's 2008 operations is included on the $\mathrm{CD}$ accompanying this report.

\section{Effluent Monitoring and Environmental Surveilance}

SRS sampling locations, sample media, sampling frequency, and types of analysis are selected based on environmental regulations, exposure pathways, public concerns, and measurement capabilities. The selections also reflect the site's commitment to (1) safety; (2) protecting human health; (3) reducing the risks associated with past, present, and future operations; (4) improving cost effectiveness, and (5) meeting regulatory requirements.

\section{Releases}

Releases to the environment of radioactive and nonradioactive materials come from legacy contamination as well as from ongoing site operations.
For instance, shallow contaminated groundwatera legacy - flows slowly toward onsite streams and swamps and into the Savannah River. In ongoing site operations, releases occur during the processing of nuclear materials.

Meeting certain regulations, such as the Safe Drinking Water Act and the Clean Air Act, requires that releases of radioactive materials from site facilities be limited to very small fractions of the amount handled. The site follows an optimization philosophy that emissions will be kept as low as reasonably achievable.

\section{Pathways}

The routes that contaminants can follow to enter the environment and then reach people are known as exposure pathways. A person potentially can be exposed when he or she breathes the air, consumes locally produced foods and milk, drinks water from the Savannah River, eats fish caught from the river, or uses the river for recreational activities such as boating, swimming, etc.

One way to determine if contaminants from the site have reached the environment is through environmental monitoring. The site gathers thousands of air, water, soil, sediment, food, vegetation, and animal samples each year. The samples are analyzed for potential contaminants released from site operations, and the potential radiation exposure to the public is assessed. Samples are taken at the points where materials are released from (1) the facilities (effluent monitoring) and (2) the environment itself (environmental surveillance). SCDHEC and the Georgia Department of Natural Resources also have programs in place to monitor the environment in and around SRS.

\section{Research and Development}

The Savannah River National Laboratory (SRNL) the site's applied research and development laboratory-creates, tests, and implements solutions to SRS's technological challenges. Other environmental research is conducted at SRS by the following organizations:

- Savannah River Ecology Laboratory (SREL) More information can be obtained by contacting SREL at $803-725-2472$ or by viewing the laboratory's website at http://www.uga.edu/srel. Also, 
SREL's technical progress report for 2008 is included on the $\mathrm{CD}$ accompanying this document.

- U.S. Department of Agriculture Forest ServiceSavannah River (USFS-SR) - More information can be obtained by contacting USFS-SR at $803-725-0006$ or $803-725-0237$ or by viewing the USFS-SR website at http://www.srs.gov/ general/srfs/srfs.htm. Also, USFS-SR's 2008 report is included on the $\mathrm{CD}$ accompanying this document.

- Savannah River Archaeological Research Program (SRARP) - More information can be obtained by contacting SRARP at 803-7253623 , or by viewing the SRARP website at http:// www.srarp.org 



\title{
Environmental Management System
}

\author{
Michael E. Roper \\ Regulatory Integration \& Environmental Services
}
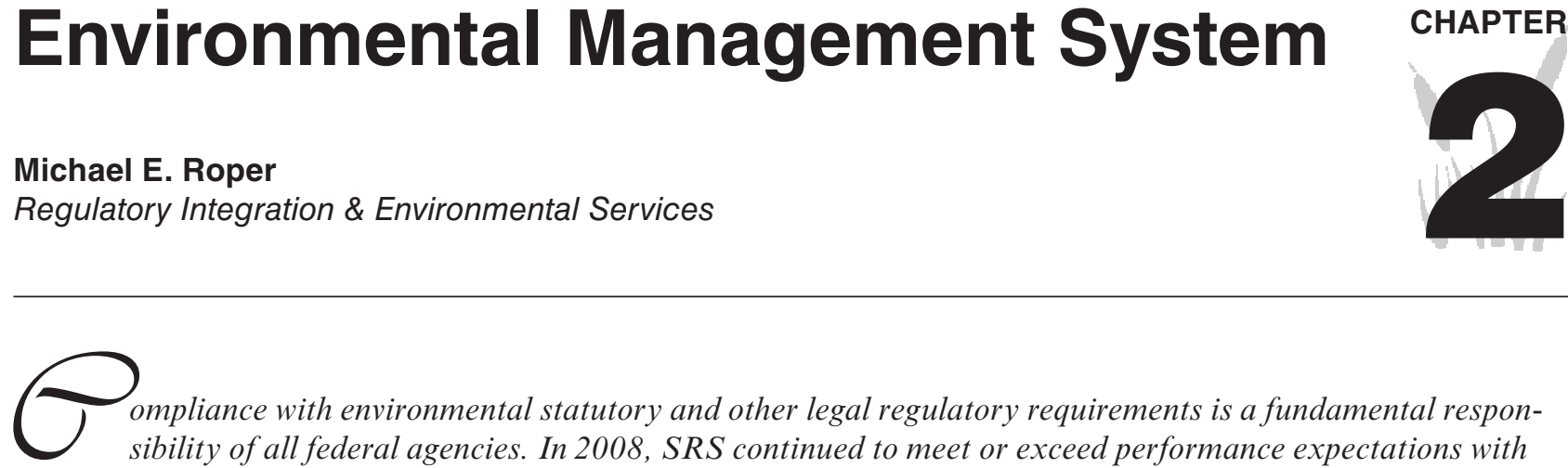

ompliance with environmental statutory and other legal regulatory requirements is a fundamental responsibility of all federal agencies. In 2008, SRS continued to meet or exceed performance expectations with respect to the management of environmental protection media (air, water, waste programs, etc.).

The Management and Operating (M\&O) contract for SRS transferred on August 1, 2008, from Washington Savannah River Company (WSRC) to Savannah River Nuclear Solutions, LLC (SRNS), and with it transitioned the responsibility for oversight of the site's Environmental Management System (EMS). This chapter focuses on the integration of numerous environmental requirements mandated by existing statutes, regulations, and policies implemented through the EMS. All contractor requirements mandated by U.S. Department of Energy (DOE) Order 450.1A, "Environmental Protection Program," are appropriately considered in the site's Integrated Safety Management System (ISMS) structure.

A management system is a tool established by an organization to manage its operations and activities in the pursuit of its policies and goals. In the case of the EMS, it is not a stand-alone environmental program or a data management program. When properly implemented, this management system enables SRS to clearly identify and establish environmental goals, develop and implement plans to meet the goals, determine measurable progress toward the goals, and take steps to ensure continuous improvement.

Executive Order (EO) 13423, "Strengthening Federal Environmental, Energy, and Transportation Management," was signed by President Bush January 24, 2007. This order directs each federal agency to use an EMS as the management framework to implement, manage, measure, and continually improve upon sustainable environmental, energy, and transportation practices. EO 13423 mandates that the EMS shall include corresponding federal agencyspecific objectives and targets to meet goals in the areas listed below.

- Energy Efficiency and Reduction of Greenhouse Gas Emissions

- Use of Renewable Energy

- Water Conservation

- Fleet Management

- Construction and Renovation of High-Performance Buildings

- Electronics Stewardship and Purchasing

- Reduction in the Use of Toxic and Hazardous Chemicals and Materials

- Acquisition of Environmentally Preferable Goods

- Pollution and Waste Prevention and Recycling

For DOE, the promulgation of EO 13423 resulted in the revision of DOE Order 450.1A, which was released June 4, 2008, as DOE Order 450.1A, "Environmental Protection Program," The new revision mandated a formal "declaration of conformance" to the EMS requirements not later than June 30, 2009. SRNS has initiated activities - including the establishment of supporting environmental, energy, and transportation management objectives and targetsto enable this "declaration," and is on track to meet the June 30 deadline. The development of corresponding EMS performance metrics is in progress. 
The following is the text of the EMS Policy in effect through 2008:

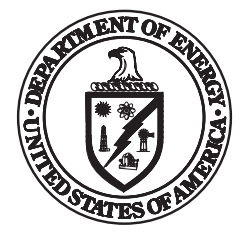

\section{Savannah River Site Environmental Management System Policy September 2008}

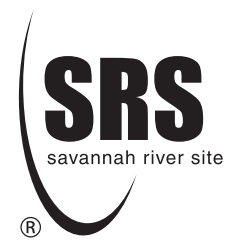

\section{OBJECTIVE}

To implement sound stewardship practices that are protective of the air, water, land, and other natural and cultural resources impacted by Savannah River Site (SRS) operations. All activities on SRS shall be conducted in compliance with applicable laws and regulations providing for the protection of public health and the environment, to reduce the use of procedures and processes that produce hazardous wastes, and to seek ways to continuously improve the performance of activities protective of the environment. The objective of this policy is to establish a consistent site-wide approach to environmental protection through the implementation of an Environmental Management System (EMS) as part of the overall Integrated Safety Management System (ISMS). The EMS provides for the systematic planning, integrated execution, and evaluation of Site activities for (1) public health and environmental protection, (2) pollution prevention (P2), (3) compliance with applicable environmental protection requirements and (4) continuous improvement of the EMS.

\section{DIRECTIVE}

Recognizing that many aspects of operations carried out at SRS may impact the environment, the SRS policy is that all employees, contractors, subcontractors, and other entities performing work at SRS shall abide by the directives in this document. This document serves as the primary documentation for the environmental goals and objectives of SRS and shall be available to the public. It shall be centrally maintained and updated as necessary to reflect the changing needs, mission, vision, and goals of SRS. The Department of Energy-Savannah River Operations Office (DOE-SR), Savannah River Nuclear Solutions (SRNS), Washington Savannah River Company (WSRC), Wackenhut Services Incorporated-Savannah River Site (WSI-SRS), Savannah River Ecology Laboratory (SREL), National Nuclear Security Administration-Savannah River Site Office (NNSASRSO), National Nuclear Security Administration-Office of Site Engineering/Construction Management (NNSA-OSECM), the United States Forest Service-Savannah River (USFS-SR), Parsons, and Shaw AREVA MOX Services endorse the principles stated in this policy.

The Environmental Management System pursues and measures continuous improvement in performance by establishing and maintaining documented environmental objectives and targets that correspond to SRS's mission, vision, and core values. The environmental objectives and targets shall be established for relevant functions including DOE-SR, NNSA-SRSO, NNSA-OSECM, and all contractors, subcontractors, and other entities performing work at SRS for all activities having actual or potentially significant environmental impacts.

DOE-SR, NNSA-SRSO, and NNSA-OSECM, and all contractors, subcontractors, and other entities performing work at SRS shall:

1. Manage the SRS environment, natural resources, products, waste, and contaminated materials so as to eliminate or mitigate any threat to human health or the environment at the earliest opportunity and implement process improvements, as appropriate, to ensure continuous improvements, as appropriate, to ensure continuous improvement of performance in environmental management. 
2. Develop policies, procedures, and training as needed to identify activities with significant environmental impacts; to manage, control, and mitigate the impacts of these activities; and to assess performance and implement corrective actions where needed.

3. Implement a pollution prevention program to reduce waste generation, releases of pollutants, future waste management and pollution control costs, and to promote energy efficiency.

4. Conduct operations in compliance with all applicable federal, state, and local laws, regulations, statutes, executive orders, directives, and standards.

5. Work cooperatively and openly with appropriate local, state, federal agencies, public stakeholders, and site employees to prevent pollution, achieve environmental compliance, conduct cleanup and restoration activities, enhance environmental quality, and ensure the protection of workers and the public.

6. Design, develop, operate, maintain, decommission, and deactivate facilities and perform operations in a manner that shall be resource efficient and will protect and improve the quality of the environment for future generations and continue to maintain SRS as a unique national environmental asset.

7. Recognize that the responsibility for quality communications rests with each individual employee and that it shall be the responsibility of all employees to identify and communicate ideas for improving environmental protection activities and programs at the site.

8. Ensure the early identification of, and appropriate response to, potential adverse environmental impacts associated with DOE operations, including as appropriate, preoperational characterization and assessment; and effluent and surveillance monitoring.

9. Promote the long-term stewardship of SRS's natural and cultural resources throughout its operational, closure, and post-closure life cycle.

Adherence to and programmatic implementation of this policy shall be the responsibility of the DOE-SR, NNSA-SRSO, and NNSA-OSECM managers in coordination with the contractors, subcontractors, and other entities performing work at SRS.

Original policy document signed by the following:

Jeffrey M. Allison, Manager

Savannah River Operations Office

Charles L. Munns, President and CEO

Savannah River Nuclear Solutions, LLC

R. Kevin Hall, Acting Manager NNSA Savannah River Site Office

Stephen F. Piccolo, President

Washington Savannah River Company, LLC

Kenneth A. Chacey, Director

NNSA Office of Site Engineering/

Construction Management
Dr. Carl W. Bergmann, Director

Savannah River Ecology Laboratory

David Stinson, President

Shaw AREVA MOX Services

Mark R. Breor, Vice President \& Project Manager Parsons

Randy Garver, Senior Vice President and

General Manager,

Wackenhut Services Incorporated - SRS

Keith Lawrence, Forest Manager

USDA Forest Service - Savannah River 


\section{SRS EMS Implementation}

The International Organization for Standardization (ISO) 14001 Standard, Environmental Management System, defines the structure for implementing EMS and improving environmental performance. The process-based structure of the ISO 14001 Standard is based on the "Plan-Do-Check-Act" improvement cycle. The standard requires an organization to develop an environmental policy, create plans to implement the policy, implement the plans, check progress and take corrective actions, and review the system annually to ensure its adequacy and effectiveness. The SRS EMS no longer is subject to an independent third-party audit to maintain ISO 14001 certification; however, it does undergo an annual internal assessment, with DOE-SR oversight, that evaluates conformity to the 17 elements of the (ISO) 14001 Standard. Additionally, under the provisions of the new DOE Order 450.1A, there is a requirement that in the initial year of implementation (i.e., 2009) and every third year thereafter, an independent external audit is required to ensure continued conformance to the 17 elements of the ISO 14001 Standard, as well as to specific requirements contained within the order. The sections that follow describe the 17 elements that demonstrate SRS implementation of the ISO 14001 Standard.

\section{Environmental Policy}

The SRS EMS Policy is a statement of the site's intention to implement sound stewardship practices that are protective of the air, water, land, and other natural cultural resources impacted by SRS operations. The objective of this policy is to establish a consistent sitewide approach to environmental protection through the implementation of an EMS as part of the overall ISMS. The SRS EMS provides for the systematic planning, integrated execution, and evaluation of site activities for (1) public health and environmental protection, (2) pollution prevention (P2), (3) compliance with applicable environmental protection requirements, and (4) continuous improvement of the EMS.

\section{Environmental Aspects and Impacts}

Determining environmental aspects (elements of activities, products, processes, and services that could have a significant impact on the environment) is critical to the EMS process. It equates to analyzing hazards via the ISMS review protocol. Identifying the SRS environmental aspects is not the end of the process. Work activities, whether routine or unusual, must consider whether these aspects are a potential part of the work activity. This leads to the development and implementation of controls necessary to mitigate the potential that the action will adversely affect the environment. SRS has determined that the following aspects of its operations have the potential to affect the environment:

- Air pollutants

- Alternative fuel use and petroleum conservation

- Asbestos emissions

- Biological hazards

- Building performance and sustainable design

- Chemical use and storage

- Contaminated site disturbance

- Cultural/historical resource disturbance

- Deactivation and demolition

- Discharge of wastewater systems or groundwater

- Drinking water contamination

- Ecological research

- Electronics management

- Energy efficiency and greenhouse gases

- Environmental remediation development, demonstration, and deployment

- Hazardous or mixed waste generation and management

- Hazardous or radiological material or waste packaging and transportation

- Industrial waste generation and management

- Interaction with wildlife and habitat

- Managing surplus property and materials

- PCB contamination 
- Pollution prevention

- Procurement of environmentally preferable goods

- Radioactive material use and storage

- Radioactive waste generation and management

- Radionuclides

- Renewable energy

- Solid waste (hazardous, nonhazardous, sanitary, nonradiological)

- Storage of hazardous, mixed, or radioactive materials or wastes in tanks

- Surface water or stormwater contamination

- Transportation (fleet) management

- Use, reuse, and recycling of resources

- Underground and aboveground storage tank management

- Water use (conservation)

- Nanomaterials

\section{Legal and Other Requirements}

Regulatory and DOE requirements for environmental programs are included in the site's Standards/Requirements Identification Document(S/RID), Functional Area (FA) 20 - Environmental Protection. The purpose of FA 20 is to address environmental, safety, and health requirements related to environmental protection activities undertaken by the $\mathrm{M} \& \mathrm{O}$ contractor on behalf of DOE at SRS. Sources include DOE Order 5400.5 ("Radiation Protection of the Public and Environment"), DOE Order 450.1, DOE Order 451.1B ("National Environmental Policy Act Compliance Program"), applicable Codes of Federal Regulations, and State of South Carolina pertinent directives. The environmental protection S/RID functional area includes activities required to protect the environment and the health of the public and workers. This S/RID addresses the technical and programmatic requirements from applicable standards, laws, and regulations.

\section{Objectives, Targets, and Programs}

The EMS pursues and measures continual improvement in performance by establishing and maintaining documented environmental objectives and targets that counterbalance SRS activities having actual or potentially significant environmental impacts. Objectives and targets are established to 1) achieve full compliance with applicable environmental requirements, 2) devote resources to specific pollution prevention initiatives, and 3) ensure responsible stewardship of natural and historical resources at SRS. The SRS goals and objectives are described in the following document references:

Pollution Prevention (P2) Program - The SRS P2 program is addressed by and documented in the site's Environmental Compliance Manual (3Q), Procedure 6.11 ("Pollution Prevention Program"), with specific annual reduction goals agreed upon by the $\mathrm{M} \& \mathrm{O}$ contractor and DOE-SR.

Natural Resources Management Plan (NRMP) The USFS-SR uses the NRMP to provide strategic guidance for SRS natural resource programs, and furthers the mission of SRS by helping to ensure responsible stewardship of the environmental resources at SRS.

WSI-SRS Annual Operational Plan (AOP) - The AOP identifies each task to be performed by WSISRS with respect to major operations or programs defined by DOE-SR. Because of security requirments, the WSI-AOP is not available publicly; however, information about it can be obtained by contacting the manager of WSI's Contracts and Resources Management Department at 803-952-7565.

\section{Resources, Roles, and Responsibilities}

All SRS employees have specific roles and responsibilities in key areas, including environmental protection. Environmental and waste management technical support personnel assist site line organizations with developing and meeting their environmental responsibilities.

\section{Competence, Training, and Awareness}

The purpose of SRS environmental training programs is to ensure that personnel whose actions could have environmental consequences are properly trained and made aware of their responsibilities to 
protect the environment, workers, and the public. EMS requirements have been provided to employees whose responsibilities include environmental protection and regulatory compliance. EMS awareness training is included within the General Employee Training Program for visitors and subcontractors. Additionally, all site employees are required to complete Consolidated Annual Training each year that contains EMS information.

\section{Communication}

SRS continues to improve internal and external communications on environmental issues. Many policies and procedures guide communications at SRS, ranging from the general site policy to forms and techniques addressed in facility-specific procedures. Additionally, SRS solicits input from interested parties such as community members, activists, elected officials, and regulators. The SRS Citizen's Advisory Board provides advice and recommendations to DOE on environmental compliance, remediation, waste management, facilities decommissioning, and related issues. Ex-officio members from DOE, the U.S. Environmental Protection Agency Region IV, the South Carolina Department of Health and Environmental Control, and the Georgia Department of Natural Resources participate in board activities. At the core of the communication and community involvement programs are the SRS EMS Policy and the SRS Federal Facility Agreement Community Involvement Plan.

\section{Documentation}

The following sources document ways that various SRS organizations describe or manage their environmental management systems:

- "SRS Environmental Management System Manual," G-TM-G-0001

- SRM 300.1.1B, Chapter 1, Section 1.2, "DOESR Functions, Responsibilities, and Authorities Procedure"

- SREL Environmental Management Program Description

- "WSI-SR Environmental Management System Implementation Plan," WSI 1-05

- "SRS Environmental Management System Policy"

\section{Operational Control}

The operational control element of the EMS is intended to ensure that operational controls are in place to carry out the environmental policy-related activities of regulatory compliance, pollution prevention, and continuous improvement by SRS management. The Assisted Hazards Analysis process and Environmental Evaluation Checklists (EECs) are vital components of this program.

\section{Emergency Preparedness and Response}

SRS emergency plans and programs include occurrences categorized as environmental emergencies.

Documents that guide the emergency preparedness process are referenced below.

- 1-01 (“Management Policies"), 4.12, "Emergency Preparedness"

- SCD-7, "Savannah River Site Emergency Plan" (includes drills and exercises)

- 9B, "Site Item Reportability and Issue Management (SIRIM)"

- Central Services Works Engineering Spill Response Team procedures

- USFS-SR Emergency Response and Evacuation Plan and Emergency Spill Procedure

- WSI-SRS Procedure 1-6816, "Emergency Management Plan"

- SREL Safety Manual, chapter 2, "Medical and Emergency Procedures"

- "SREL Occurrence Reporting Procedures" (EHS-94-0001)

- Memoranda of agreement (MOAs) and service level agreements (SLAs)

- Resource Conservation and Recovery Act Part B Permit, Volume I, General Information, Section G, Contingency Plan.

\section{Monitoring and Measurement}

Monitoring and measurement means that the key characteristics of SRS operations are monitored regularly. This 
includes effluent monitoring (radiological and nonradiological), compliance monitoring, performance monitoring, and equipment/facility monitoring (e.g., calibration of instruments). References include the following:

- 3Q1-2, (Plans and Procedures), Vol. 1, Section 1000, Procedure 1002, "SRS Environmental Monitoring Plan"

- 3Q1-2 (Plans and Procedures), Vol. 1, Section 1000, Procedure 1100, "SRS Environmental Monitoring Program"

- WSRC-ESH-EMS-94-0129, "SRS EM Corrective Action Plan"

- "Environmental Geochemistry Group Operating Handbook," July 1996

- USFS-SR Post-Burn Evaluations

- USFS-SR Biological Evaluations

- SCD-4, "Assessment Performance Objectives and Criteria"

- 3Q, "Environmental Compliance Manual"

- 1Q (Quality Assurance), 12-1, "Control of Measuring and Test Equipment"

- 1Q, 12-2, "Control of Installed Process Instrumentation"

- Annual SRS Environmental Report

- USFS-SR Accomplishment Reports

- Individual Agency and Divisional Performance Indicators

- 1Q, 15-1, "Control of Nonconforming Items"

- 1-01, 5.35, "Corrective Action Program"

- WSI-SRS Consolidated Assessment Schedule

\section{Evaluation of Compliance}

Specific environmental legislation and regulations are evaluated and assessed on a program- or facilityspecific basis. SRS has established a process for periodically evaluating its compliance with relevant environmental regulations. This process is primarily captured in three site documents: (1) the Standards/ Requirements Identification Document (S/RID); (2) the Source and Compliance Document (SCD-4); and (3) the Assessment Manual (12Q). The procedure often is integrated into an organization's environmental, safety, and health inspection process, which is performed in a prioritized fashion by a team of experts, including one on environmental regulatory issues. Periodically — and at least semiannually —environmental support organizations conduct regulatory assessments in particular topical areas to verify the compliance status of multiple organizations throughout SRS. Finally, external regulatory agencies and/or technical experts may conduct independent audits of compliance.

\section{Nonconformance; Corrective and Preventive Actions}

Nonconformance and corrective and preventive actions include EMS nonconformance as a part of the site's quality assurance (QA) program. The application of QA procedures, therefore, supports the total EMS. For example, use of the nonconformance report form applies to environment-related equipment, instruments, facilities, and procedures. Also, instances of "nonconformance" identified by assessments and evaluations are recorded and dispositioned according to established procedures, utilizing the following resources:

- Quality Assurance Management Plan

- SRM 226.1.1C, Integrated Performance Assurance Manual, Section 8, "Corrective Action Processing and Closure Verification"

- 1-01, 5.35, "Corrective Action Program"

- 12Q (Assessment Manual), FEB-1, "Facility Evaluation Board"

- 1Q, "Quality Assurance Manual”

- WSI-SRS Procedure 1-3700, "Improvement/ Corrective Action Management Program"

- USFS-SR Handbook, 6309.11, "Contract Administration"

- "Evaluation and Cleanup of SREL Research Sites" (A-98-0002) 


\section{Control of Records and Documents}

The identification, maintenance, and disposition of environmental records are required by the SRS EMS. The site's records management program incorporates environmental records for these purposes. Specific documentation for programmatic environmental activities is addressed in department-level procedures. For example, Regulatory Integration and Environmental Services (RI\&ES) maintains records of correspondence with regulatory agencies. Environmental training records are maintained by the line organization requiring and conducting the training. EECs completed by facilities for specific activities are forwarded to and maintained by RI\&ES, according to the following documents:

- DOE Order 1324.5A, "Records Management Program"

- 1Q, 17.0, "Quality Assurance Records"

- 1B (Management Requirements and Procedures), 3.11, "WSRC Document and Correspondence Numbering System"

- 1B, 3.31, "Records Management"

- 1B, 3.32, "Document Control"

- WSRC IM-93-0060, "Sitewide Records Inventory and Disposition Schedule (RIDS)", Section IV:

"Environmental"

- $\quad$ SRIP 200, Chapter 241.1, "Records Management Program"

- WSI-SRS Procedure 1-1507, "Records Management Requirements"

- U.S. Forest Service Handbook, 6209.11, "Records Management"

- ESH 94-0033, "SREL Environmental Management Plan"

\section{Internal Audits}

SRS audits are incorporated into the DOE and M\&O assessment programs to verify that the site's EMS is functioning as intended. SRS utilizes a Facility Evaluation Board (FEB) to conduct independent performance-based assessments of site programs to satisfy contractual and regulatory obligations.

The independent assessment program periodically performs performance-based assessments of facilities/projects, support departments, and SRS programs. Other activities for which environment, safety, health, radiological controls, or quality assurance oversight is required also are assessed.

The M\&O's Office of Contractor Assurance prepares the annual FEB schedule for the M\&O President. Determination of facility assessment scheduling considers, but is not limited to, the following criteria:

- Hazard level, including (1) Radiological categories 1, 2, or 3 and (2) Industrial (inherent facility safety and health hazards)

- Facility risk, as defined by the facility's authorization basis documentation

- Operational status (shutdown, standby, operating, startup test mode, or closure)

- Number and frequency of reportable occurrences during the previous 12 months, including type, root-cause factors, and status of action items

- Type of last assessment

- Time since last assessment

- Grade from last FEB evaluation

- Regulatory-driven assessment frequencies

- Requests for evaluation by site management

\section{Management Review}

The SRS EMS Policy requires periodic evaluations of the effectiveness of the EMS. Guidelines are intended to keep the management review focused on continuous improvement. Oversight of SRS's annual EMS review is the responsibility of DOE-SR's Environmental Quality Management Division.

For Further Information Should additional information be required relative to this chapter, contact Michael Roper at michael.roper@srs.gov. 


\section{Environmental Compliance}

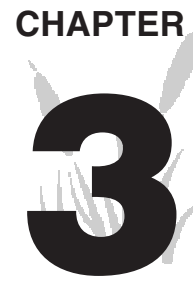

Michael E. Roper

Regulatory Integration \& Environmental Services

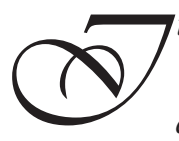

t is the policy of the U.S. Department of Energy (DOE) that all activities at the Savannah River Site

(SRS) will be carried out in full compliance with applicable federal, state, and local environmental laws

and regulations, and with DOE orders, notices, directives, policies, and guidance. Compliance with

environmental regulations and with DOE orders related to environmental protection is a critical part of the operations at SRS.

The purpose of this chapter is to report on the status of SRS compliance with these various statutes and programmatic documents. Some key regulations with which SRS must comply, and the compliance status of each, are listed in table 3-1.

This chapter also provides information on Notices of Violation (NOVs) issued by the U.S. Environmental Protection Agency (EPA) or the South Carolina Department of Health and Environmental Control (SCDHEC). NOVs are the procedures that allege potential violations of an organization's permits or environmental laws or regulations. SRS received three allegations of violation in 2008 (two involving sanitary wastewater releases and one involving air emissions). The sanitary wastewater release allegations did not result in an administrative hearing to determine if a violation occurred. The parties continued to negotiate a settlement of the air emissions release dispute in 2008, and were expected to resolve it by consent in 2009. See the "Clean Water Act" and "Clean Air Act" sections of this chapter for additional details.

\section{Compliance Activities}

\section{Resource Conservation and Recovery Act}

The Resource Conservation and Recovery Act (RCRA) was passed in 1976 to address solid and hazardous waste management. The law covers such wastes as spent solvents, batteries, and many other discarded substances potentially harmful to human health and the environment. Amendments to RCRA regulate nonhazardous solid waste, underground storage tanks (USTs) and solid waste management units (units that historically contained or managed solid waste).

Hazardous waste generators, including SRS, must follow specific requirements for handling these wastes.

\section{Underground Storage Tanks}

The 19 USTs at SRS that contain petroleum products, as defined by the Comprehensive Environmental Response, Compensation, and Liability Act (CERCLA), are regulated under Subtitle I of RCRA. These tanks require a compliance certificate annually from SCDHEC to continue operations. SCDHEC conducts an annual compliance inspection and records audit prior to issuing the compliance certificate. SCDHEC's 2008 inspection and audit found all 19 tanks to be in compliance, marking six straight years without a violation.

\section{Land Disposal Restrictions}

The 1984 RCRA amendments established Land Disposal Restrictions (LDRs) to minimize the threat of hazardous constituents migrating to groundwater sources. The same restrictions apply to mixed (hazardous and radioactive) waste.

\section{Federal Facility Compliance Act}

The Federal Facility Compliance Act (FFCAct) was signed into law in October 1992 as an amendment to 
Table 3-1

Laws/Regulations Applicable to SRS

Legislation

What It Requires

In Compliance

RCRA

Resource Conservation and

Recovery Act (1976)

FFCAct

Federal Facility Compliance Act (1992)

\section{CERCLA; SARA}

Comprehensive Environmental

Response, Compensation, and

Liability Act (1980); Superfund

Amendments and Reauthorization

Act (1986)

\section{EPCRA}

Emergency Planning and

Community Right-to-Know Act (1986)

\section{NEPA}

National Environmental Policy Act (1969)

\section{SDWA}

Safe Drinking Water Act (1974)

\section{CWA $^{a}$}

Clean Water Act (1977)

\section{RHA}

Rivers and Harbors Act of 1899 ,

Section 10

\section{FIFRA}

Federal Insecticide, Fungicide, and Rodenticide Act (1947)

\section{CAA (NESHAP)}

Clean Air Act (1970), (National

Emission Standards for

Hazardous Air Pollutants)

TSCA

Toxic Substances Control Act (1976)

\section{ESA}

Endangered Species Act (1973)

\section{NHPA}

National Historic Preservation Act (1966)
The management of hazardous and nonhazardous solid wastes and of underground storage tanks containing hazardous substances and petroleum products

The development by DOE of schedules for mixed waste treatment to meet LDR requirements

The establishment of liability compensation, cleanup, and emergency response for hazardous substances released to the environment

The reporting of hazardous substances used on site (and their releases) to EPA, state, and local planning units

The evaluation of the potential environmental impacts of proposed federal activities and alternatives

The protection of public drinking water

The regulation of liquid discharges at outfalls (e.g., drains or pipes) that carry effluents to streams (NPDES, Section 402); regulation of dredge and fill of U.S. waters (Section 404) and associated water quality for those activities (WQC, Section 401).

The regulation of construction over and obstruction of navigable waters of the U.S.

The regulation of restricted-use pesticides through a state-administered certification program

The establishment of air quality standards for criteria pollutants, such as sulfur dioxide and particulate matter, and hazardous air emissions, such as radionuclides and benzene

The regulation of $\mathrm{PCBs}$, radon, asbestos, and lead used in sensitive populations, as well as evaluation and notification to EPA of new chemicals and significant new uses of existing chemicals

The protection of critically imperiled species from extinction

The preservation of historical and archaeological sites
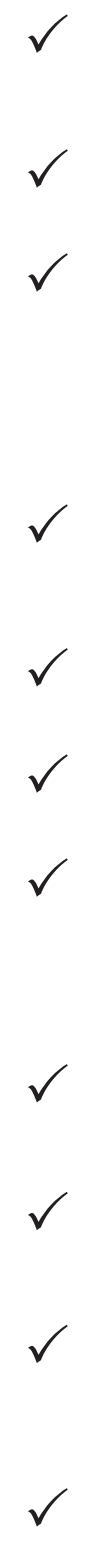

${ }^{\text {a }}$ A total of three NOVs received by SRS under the CWA and the CAA in 2008 reflected momentary exceedances of standards; however, the programs under these laws generally remained in compliance. 
the Solid Waste Disposal Act to add provisions concerning the application of certain requirements and sanctions to federal facilities. A Site Treatment Plan (STP) (WSRC-TR-94-0608) consent order (95-22HW, as amended) was obtained and implemented in 1995, as required by the FFCAct. A Statement of Mutual Understanding (SMU) for Cleanup Credits was executed by SCDHEC in October 2003, allowing SRS to earn credits for certain accelerated cleanup actions. Credits then can be applied to the STP commitment schedules. SRS submitted to SCDHEC an annual update to the approved STP in November 2008 (SRNS-TR-2008-00101, Rev 0) that identified changes in mixed waste treatment and inventory. Changes in the 2008 STP update include

- updating the commitment summary for the new fiscal year

- updating the status of several waste streams

- updating the treatment technology for SR-W045 PUREX Organic Waste

- revising the salt processing facility information

- revising the current cumulative inventory

Also documented in the 2008 update is SRS's completion of 928 transuranic (TRU) waste shipments (as of September 1) to the Waste Isolation Pilot Plant (WIPP) facility in New Mexico.

STP updates will continue to be produced annually unless provisions of the consent order are modified.

\section{Liquid Radioactive Waste Tank Closure}

The primary regulatory goal of SRS's waste tank closure program at the F-Area and H-Area liquid radioactive waste tank farms is to close the tank systems in a way that protects public health and the environment in accordance with SCDHEC's Regulation 61-82, "Proper Closeout of Wastewater Treatment Facilities." Under this program, the first two high-level waste tanks (i.e., 17F and 20F) were closed in 1997.

During 2008, Tanks 18F and 19F remained isolated, requiring only administrative safety basis controls, and a new enhanced mechanical cleaning technology was deployed to continue waste removal efforts.

\section{Waste Minimization/Pollution Prevention (WMin/P2) Program}

2008 Program Results and Highlights The SRS WMin/P2 Program continued to achieve significant results in 2008. All required site waste generators demonstrated active participation in the program through documented pollution avoidance and/or direct mission support activities for site recycling. Site employee P2 awareness was increased through online articles and general employee and job-specific training.

The WMin/P2 Program met all DOE and regulatory agency reporting requirements. Program accomplishments during 2008 included the following:

- $\quad$ SRS documented $27 \mathrm{P} 2$ projects, resulting in an annualized avoidance of $1,108 \mathrm{~m}^{3}$ of hazardous and radioactive waste, which exceeded the site's 2008 P2 Program waste avoidance performance goal of $671 \mathrm{~m}^{3}$ by more than 65 percent. Annual cost avoidance resulting from the 27 documented $\mathrm{P} 2$ projects is $\$ 8.6$ million.

- DOE-HQ announced that SRS won two National DOE P2 Awards. Winning nominations were: SRS Greening Electronics and $H$-Canyon Pollution Prevention Initiatives. These awards were forwarded to next-tier competitions, with SRS Greening Electronics winning a P2 STAR Honorable Mention Award. SRS prepared input for an "EMCast" highlighting the SRS Greening Electronics program for DOE-HQ EM to share with other sites.

- $\quad$ SRS was selected to receive the Department of Energy Transformational Energy Action Management (TEAM) Effectiveness Awardpresented by the Federal Energy Management Program (FEMP), Office of Energy Efficiency and Renewable Energy - to honor outstanding achievements to implement the Secretary of Energy's TEAM initiatives.

SRS participates in EPA voluntary $\mathrm{P} 2$ programs by maintaining its EPA Waste Wise and EPA National Partnership for Environmental Priorities memberships. SRS continued its participation in the Federal Electronic Reuse and Recycle Campaign, and reported 358,852 pounds of electronics recycled and reused for the contest period. 
SRS recycled 37 percent (863 metric tons) of the routine sanitary waste stream using the North Augusta Material Recovery Facility and Three Rivers Regional Landfill services. This exceeded the 35 -percent SRS sanitary waste recycling goal established for 2008.

Pollution prevention support was provided to DOEHQ program offices in 2008. Working through DOE-EM, support was provided to the DOE-EH and DOE-NNSA P2 programs. The EM P2 Program sponsored one employee to attend the Federal Environmental Executive P2 Workshop, which also included a separate DOE-HQ P2 Planning Workshop.

The SRS pollution prevention team also supported P2 awareness in 2008 on site and in the local community, as follows:

- Onsite awareness was increased through online articles and general employee and job-specific training.

- Handout items were provided during the SRS Safety Conference Family Night event to promote pollution prevention.

- The P2 Program provided financial support and voluntary hours for the North Augusta Kids Earth Day, which hosted 30-plus separate exhibits to educate and share with the more than 2,000 attendees.

- The P2 Program provided financial support and voluntary hours for the Environmental Science Educator's Cooperative (ESEC), including sponsorship of a graded session at the 2008 ECOMEET - a hands-on environmental competition for middle school students. This year's event was held at the Watson Brown Foundation Center, Thomson, Georgia, with 22 teams from Georgia and South Carolina participating. In addition, the P2 Program supported two ESEC Electronics Recycle Days, and the Environmental Teacher of the Year Award, both in Augusta, Georgia.

\section{Comprehensive Environmental Response, Compensation, and Liability Act}

SRS was placed on the National Priority List in December 1989, under the legislative authority of CERCLA, as amended by the Superfund Amend- ments and Reauthorization Act of 1986 (SARA). In accordance with Section 120 of CERCLA, DOE, EPA Region 4, and SCDHEC entered into the SRS Federal Facility Agreement (FFA), which became effective August 16, 1993, and which directs the comprehensive environmental remediation of the site.

SRS has 515 waste units in the Soil and Groundwater Closure Projects program, including RCRA/ CERCLA units, Site Evaluation Areas, and facilities covered under the SRS RCRA permit. At the beginning of FY08, 371 units were complete or in the remediation phase (338 complete and 33 in the remediation phase). At the end of FY08, 373 units were complete or in the remediation phase $(360 \mathrm{com}-$ plete and 13 in remediation). A summary of the FFA Milestones follows.

RCRA Facility Investigation/Remedial Investigation (RFI/RI) Field Starts were initiated for the following units in FY08:

- Gunsite 012 Rubble Pile, Rubble Pile across from Gunsite 012, and Early Construction and Operational Disposal Site (ECODS) G-3, (no building number, NBN)

- $\quad$ Gunsite 218 Rubble Pile (631-23G)

- Upper Three Runs Integrator Operable Unit (Including Tims Branch and Steed Pond) Second Phase II

Remedial Action was initiated at the following units in FY08:

- L-Area Southern Groundwater

- A-Area Burning/Rubble Pits (731-A, -1A), A-Area Rubble Pit (731-2A)

- Miscellaneous Chemical Basin/Metals Burning Pit (731-4A, -5A), A-Area Ash Pile (788-2A)

Remedial Actions were completed and Post-Construction Reports (PCRs) or Post-Construction Reports /Corrective Measures Implementation Report/Remedial Action Completion Reports (PCR/ CMIR/RACRs) were submitted for the following units in FY08:

- Chemicals, Metals, and Pesticides (CMP) Pits (080-17G, $-17.1 \mathrm{G},-18 \mathrm{G},-18.1 \mathrm{G},-18.2 \mathrm{G},-18.3 \mathrm{G}$, $-19 \mathrm{G})$ 
- M-Area Settling Basin Inactive Process Sewers to Manhole 1, 081-M (including Southern Portions of 313-M Inactive Clay Process Sewer Lines to Tims Branch, NBN and Southern Portions of 320-M Inactive Clay Process Sewer Lines from the Building Slab to the Former Security Fence, NBN)

- General Separations Area Consolidation Unit

- R-Area Reactor Seepage Basins (904-57G, $-58 \mathrm{G},-59 \mathrm{G},-60 \mathrm{G},-103 \mathrm{G},-104 \mathrm{G})$ and $108-4 \mathrm{R}$ Overflow Basin

No Interim Action Post-Construction Reports (IAPCRs) were submitted in FY08.

Removal Action Reports were issued for the following units in FY08:

- Contaminated Surficial Soil in the 741-A

Salvage Yard at the M-Area Operable Unit

- Production Area of the M-Area Operable Unit

Records of Decision (RODs) were submitted for the following units in FY08:

- C-Area Burning/Rubble Pit, 131-C and Old C-Area Burning/Rubble Pit, NBN

- P-Area Operable Unit Early Action

- M-Area Operable Unit

A ROD was approved and issued for the following unit in FY08:

- C-Area Burning/Rubble Pit, 131-C, and Old C-Area Burning/Rubble Pit, NBN

The Performance Assesment for F Tank Farm was submitted August 31, 2008, as required by Appendix $\mathrm{L}$ of the FFA.

No Explanations of Significant Difference (ESDs) were submitted, and no ESDs were issued in FY08.

Section X ("Site Evaluations") of the FFA requires SRS to submit Removal Site Evaluation (SE) reports to EPA and SCDHEC for those areas with potential or known releases of hazardous substances not identified before the effective date of the agreement.

SRS submitted three Removal SE Reports in FY08, as follows:

- Contaminated Surficial Soil in the 741-A Salvage Yard at the M-Area Operable Unit

- Miscellaneous Rubble Pile \#2

- Production Area of the M-Area Operable Unit

Section $\mathrm{X}$ of the FFA also requires SRS to submit Remedial SE Reports to the EPA and SCDHEC for those areas listed in Appendix G.I of the Agreement.

SRS did not submit any Remedial SE recommendations or revised SE reports.

A listing of all 515 waste units at SRS can be found in appendices C ("RCRA/CERCLA Units List") and $\mathrm{G}$ ("Site Evaluation List") of the FFA.

\section{Emergency Planning and Community Right-to-Know Act}

The Emergency Planning and Community Rightto-Know Act (EPCRA) of 1986 requires facilities to notify state and local emergency planning entities about their hazardous chemical inventories and to report releases of hazardous chemicals. The Pollution Prevention Act of 1990 expanded the EPCRAmandated Toxic Chemical Release Inventory report to include source reduction and recycling activities.

\section{Executive Order 12856}

Executive Order 12856, "Federal Compliance with Right-to-Know Laws and Pollution Prevention Requirements," requires that all federal facilities comply with right-to-know laws and pollution prevention requirements. SRS complies with the applicable reporting requirements for EPCRA, as indicated in table 3-2, and the site incorporates the toxic chemicals on the Toxic Release Inventory Report into its pollution prevention efforts.

\section{Chemical Inventory Report (Tier II)}

Under Section 312 of EPCRA, SRS completes an annual Tier II Chemical Inventory Report for all hazardous chemicals present at the site in excess of specified quantities during the calendar year. Hazardous chemical storage information is submitted to state and local authorities by March 1 for the previous calendar year. 


\section{Toxic Release Inventory (TRI) Report (Form R)}

Under Section 313 ("Toxic Chemical Release Reporting") of EPCRA, SRS must file an annual Toxic Release Inventory (TRI) report by July 1 for the previous year. SRS calculates chemical releases to the environment for each regulated chemical that exceeds its established threshold value and (in addition to other inventory data sets) reports the release values to EPA on Form $\mathrm{R}$ of the report. Threshold values are those quantities of regulated chemicals (as defined by EPCRA Section 313) above which additional reporting is required using the TRI Report - Form R.

Form R for 2007 was submitted to EPA July 1, 2008. SRS reported the following chemicals that exceeded their thresholds: barium, chlorine, chromium, copper, fluorine, formic acid, hydrochloric acid, lead, manganese, mercury, nickel, nitrate, nitric acid, sodium nitrite, sulfuric acid, and zinc. (NOTE: The term "exceeded" in an EPCRA context does not indicate a violation. Per EPA regulations, SARA chemical limits are established, and reporting requirements are based on these threshold values.) Specific details, including release amounts and detailed information about toxic release inventory reporting, can be viewed on the EPA website at www.epa.gov/tri/tridata.

During preparation of the 2007 SRS TRI Report Form R, it was discovered that SRS's nitrate release number was substantially higher than those documented in prior years' reports. Additional data review disclosed that the 2007 reported nitrate releases from an onsite wastewater treatment plant outfall were approximately three times greater than the amount reported in 2006. Further investigation determined that the last time analytical data were used to calculate the release of nitrate to the outfall was in 2000; the source of the data was the National Pollutant Discharge Elimination System (NPDES) 2C application. Subsequently, it was determined that a data transcription error from that wastewater treatment plant calculation sheet occurred during preparation of the 2000 TRI Report Form. The nitrate/nitrite value as nitrogen (a substantially smaller number) was transcribed, rather than the nitrate value.

In subsequent years, the new release numbers for nitrate for the sanitary wastewater facilities were calculated by using a ratio method involving flow; higher flows resulted in more nitrate being released,
Table 3-2

SRS Reporting Requirements under

"Federal Compliance with Right-to-Know

Laws and Pollution Prevention

Requirements" (Executive Order 12856)

\begin{tabular}{|lll|}
\hline $\begin{array}{l}\text { EPCRA } \\
\text { Citation }\end{array}$ & $\begin{array}{l}\text { Activity } \\
\text { Regulated }\end{array}$ & $\begin{array}{l}\text { Reported } \\
\text { in 2008 }\end{array}$ \\
$302-303$ & $\begin{array}{l}\text { Planning } \\
\text { Notification }\end{array}$ & NA $^{\mathrm{a}}$ \\
& $\begin{array}{l}\text { Extremely } \\
\text { Hazardous } \\
\text { Substances }\end{array}$ & \\
& $\begin{array}{l}\text { Release Notification } \\
\text { 311-312 }\end{array}$ & \\
& $\begin{array}{l}\text { Material Safety } \\
\text { Data Sheet / } \\
\text { Chemical Inventory }\end{array}$ & \\
& Yes \\
& Toxic Release \\
& Inventory Reporting & \\
\hline a Did not exceed reporting threshold & \\
\hline
\end{tabular}

and lower flows resulted in less nitrate being released. Because the 2000 nitrate number was incorrect, use of the "flow ratio" method propagated the reporting error for nitrate through reporting year 2006. Corrective actions were developed in 2008, including a voluntary self-disclosure to EPA, an extent-of-condition analysis to ensure that similar issues had not occurred in the reporting of other release data, and revisions to TRI submissions for reporting years 2000-2006. EPA is reviewing all documentation submitted.

\section{National Environmental Policy Act}

The National Environmental Policy Act (NEPA) is the federal government's basic charter for assuring the protection and wise use of the "human environment" by federal agencies. NEPA's procedures require that federal agencies identify and consider the potential environmental consequences of their proposed actions early in the planning process so they can make informed, environmentally sound decisions regarding project design and implementation. The NEPA process at SRS is initiated by completing 
an Environmental Evaluation Checklist (EEC). The EEC is used to characterize the proposed action, identify any potential environmental concerns, and determine which level of NEPA review (if any) will be required \{i.e., categorical exclusion determination (CX), environmental assessment (EA), or environmental impact statement (EIS)\}. A total of 414 SRSrelated NEPA reviews were conducted in 2008 (see table 3-3). The following is a listing of major NEPA reviews conducted during 2008, some of which will complete in 2009:

- Surplus Plutonium Disposition Supplemental EIS (DOE/EIS-0283-S2) - In this Supplemental EIS (SEIS), DOE will evaluate the potential impacts of implementing selected surplus plutonium disposition alternatives at SRS. Disposition alternatives being considered include (a) processing in H-Canyon, (b) using the Mixed Oxide (MOX) Fuel Fabrication Facility, and (c) using a can-in-canister immobilization (glass or ceramic) process. Work on the draft EIS was suspended late in 2008 to accommodate feasibility studies of additional alternatives. The schedule for this SEIS is uncertain.

- Programmatic EIS for Disposition of Scrap Metals (DOE/EIS-0327) - In this Programmatic EIS (PEIS), DOE will evaluate alternatives for the disposition of scrap metals that may have been in radiological areas. The disposition alternatives include (a) continuation of the suspension on unrestricted release of metals for recycling, (b) unrestricted release of scrap metals for recycling, and (c) disposal. The draft document has not been issued and the schedule for completing this PEIS is uncertain.

- EIS for the Disposal of Greater-Than-Class-C Low-Level Radioactive Waste (GTCC LLW) (DOE/EIS-0375) - In this EIS, DOE will evaluate the impacts of disposing GTCC LLW in a geologic repository, in intermediate-depth boreholes, or in enhanced near-surface disposal facilities. Candidate DOE sites being considered for these disposal facilities include SRS, Idaho National Laboratory, Los Alamos National Laboratory, WIPP, Nevada Test Site, Oak Ridge, Hanford, and Yucca Mountain. DOE also will consider generic commercial disposal of GTCC LLW at arid and humid locations. Disposal alternatives being considered for SRS include an intermediate depth borehole facility and an enhanced near-surface facility. Publica- tion of the draft and final EISs is expected in May 2009 and June 2010, respectively.

- Complex Transformation Supplemental Programmatic EIS (DOE/EIS-0236-S4) - In this supplemental PEIS, DOE evaluated the environmental impacts associated with the National Nuclear Security Administration's proposed modernization of the nuclear weapons complex. The preferred alternative is to consolidate all tritium R\&D activities at SRS. The final PEIS and two RODs were issued October 24 and December 19, respectively. DOE decided to consolidate tritium R\&D activities at SRS.

- Programmatic EIS for the Global Nuclear Energy Partnership (GNEP) Technology Demonstration Program (DOE/EIS-0396) - The GNEP program would encourage expansion of domestic and international nuclear energy produc-

Table 3-3

Summary of SRS-Related NEPA Reviews in 2008

Type of NEPA Review Number

Categorical Exclusion Determinations 153

"All No" EEC Determinations ${ }^{a} \quad 235$

Actions Tiered to Previous

NEPA Reviews

16

Environmental Impact Statements ${ }^{b}$

Supplement Analysis ${ }^{c}$

5

Interim Action

Revised FONSI

Environmental Assessments ${ }^{d}$

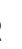

Total SRS-Related NEPA Reviews

\footnotetext{
a Proposed actions that require no further NEPA review

b DOE/EIS-0283-S2 (in progress); DOE/ EIS-0375 (in progress); DOE/EIS-0236-S4 (complete); DOE/EIS-0396 (in progress); DOE/ EIS-0327 (in progress)

${ }^{c}$ Discontinued SA for SRS Salt Processing Alternatives FSEIS not included in the count

d DOE/EA-1605 (complete); DOE/EA-1606 (in progress)
} 
tion while reducing nuclear proliferation risks. The Draft PEIS was published October 17. The public comment period, which was extended for 90 days, will close March 16, 2009. DOE anticipates that this PEIS will be cancelled in 2009.

- Supplement Analysis (SA): SRS Spent Nuclear Fuel Management FEIS (DOE/EIS-0279) - In this SA, DOE is reviewing the continued use of $\mathrm{H}$-Canyon to process spent nuclear fuel receipts and other highly enriched uranium material through 2019. As of late 2008, there were no projected approval dates for the SA or amended ROD.

- Interim Action (IA) Determination: Surplus Plutonium Disposition Supplemental EIS (DOE/ EIS-0283-S2) - In this IA, DOE reviewed the proposed processing of a limited amount of plutonium surveillance material in H-Canyon for vitrification at the Defense Waste Processing Facility prior to completion of the SPD SEIS. DOE's review found that the proposed action was an allowable interim action because DOE had evaluated the impacts in the Interim Management Nuclear Materials EIS. The IA was completed in December.

- Supplement Analysis: SRS Salt Processing Alternatives Final SEIS (DOE/EIS-0082-S2) - In this SA, DOE was to review the-construction of a Saltstone Feed Facility to provide lag storage for low-level liquid waste so that Tank 50 could be placed back into HLW service. This SA was discontinued due to lack of project funding.

- Environmental Assessment for the Biomass Cogeneration and Heating Facilities at SRS (DOE/ EA-1605) - In this EA, DOE evaluated the potential impacts of constructing and operating a biomass-fueled cogeneration facility at SRS. This plant would replace the existing coal-fired D-Area powerhouse. The proposed action also included replacing the K-Area steam plant with two smaller biomass-fueled boilers in K-Area and L-Area. Clean biomass and bioderived fuels will be the fuel source for all the new boilers. The final EA and Finding of No Significant Impact (FONSI) were published in August.

- Environmental Assessment for the Proposed Use of SRS Lands for Military Training (DOE)
$E A-1606)$ - In this EA, DOE will evaluate the potential impacts associated with the proposed use of SRS lands for military training by the Department of Defense (e.g., U.S. Army). Publication of the draft EA is expected in 2010.

- Revised FONSI: EA for the Natural Fluctuation of Water Level in Par Pond and Reduced Water flow in Steel Creek below L-Lake at the SRS (DOE/EA-1070) - This revised FONSI reduces the required flow from L-Lake into Steel Creek and from PAR Pond into Lower Three Runs to 4.5 cubic feet per second (cfs) and $5 \mathrm{cfs}$, respectively. DOE had not approved the document by the end of 2008.

\section{Safe Drinking Water Act}

The federal Safe Drinking Water Act (SDWA) was enacted in 1974 to protect public drinking water supplies. SRS domestic water is supplied by groundwater sources. The A-Area, D-Area, and K-Area systems are actively regulated by SCDHEC, while the remaining smaller water systems receive a reduced level of regulatory oversight.

Samples are collected and analyzed periodically by SRS and SCDHEC to ensure that all site domestic water systems meet SCDHEC and EPA bacteriological and chemical drinking water quality standards. All samples collected in 2008 met these standards.

Although the B-Area Bottled Water Facility is not listed by SCDHEC as a public water system, the SC D HEC Division of Food Protection continued to conduct periodic inspections of this facility until it was closed formally in September. Results from routine bacteriological analyses performed in 2008 met SCDHEC and Food and Drug Administration (FDA) water quality standards.

\section{Clean Water Act}

\section{National Pollutant Discharge Elimination System}

The Clean Water Act (CWA) of 1972 created the NPDES program, which is administered by SCDHEC under EPA authority. The program is designed to protect surface waters by limiting releases of nonradiological effluents into streams, reservoirs, and wetlands. 
SRS had four NPDES permits in 2008:

- Two permits for industrial wastewater discharges (SC0047431, which covered the D-Area Powerhouse, and SC0000175, which covered the remainder of the site)

- Two general permits for stormwater discharges (SCR000000 for industrial and SCR100000 for construction)

The site also had one no-discharge permit for land applications (ND0072125).

More information about the NPDES permits can be found in chapter 4, "Effluent Monitoring."

The results of monitoring for compliance with the industrial wastewater discharge permit at SRS were reported to SCDHEC in the site's monthly discharge monitoring reports, as required by the permit.

In 2008, SRS received from SCDHEC a final rating of "satisfactory" - the highest rating given - for the annual 2-week NPDES 3560 Compliance Sampling Inspection of the site's NPDES-permitted outfalls.

The outfalls covered by the industrial stormwater permit (SCR000000) were reevaluated again in 2007. This resulted in the development of a new sampling plan implemented in 2008. No new issues were identified in 2008. Results of stormwater outfall sampling appear in an effluent monitoring data table on the $\mathrm{CD}$ accompanying this report.

Under the Code of Federal Regulations (CFR) Oil Pollution Prevention regulation (40 CFR 112), SRS must report petroleum product discharges of 1,000 gallons or more into or upon the navigable waters of the United States, or petroleum product discharges in harmful quantities that result in oil sheens. No such incidents occurred at the site during 2008.

SRS has an agreement with SCDHEC to report petroleum product discharges of 25 gallons or more to the environment. No such incidents occurred in 2008.

\section{Notices of Violation (CWA)}

The site reported five NPDES permit condition exceptions in 2008. Such required reporting does not mean a violation of a law, regulation, or permit. Of the five reported events, two resulted in allegations of violations.

On June 4, regarding the K-12 Outfall, SCDHEC notified SRS of an allegation of violation concerning total suspended solids (TSS) at this outfall. SRS notified SCDHEC that extensive maintenance records indicated the plant was properly maintained, and that investigations had failed to determine a reason for any problems involving TSS. Based on the information provided to SCDHEC, the agency decided not to refer for enforcement.

On September 25, SRS received an allegation of violation from SCDHEC based upon a July 16, 2008, exception at the G-10 Outfall, without referring the allegation for an administrative hearing to determine if a violation occurred. SRS sent SCDHEC a response indicating that the wastewater treatment unit was maintained and operated properly, that the samples were taken properly, and that 10 years of data indicated this exception was well beyond any other experienced at the plant. Even with this exception, the compliance ratio at this plant was still 99.60 percent. Based on this review, the high fecal coliform sample result appeared to be an anomaly, and SRS requested that SCDHEC not make a final agency determination that the regulated effluent discharge violated SC Code Section 48-1-110(d). On October 17, SCDHEC informed SRS that it will "absolutely not" take any enforcement action based on this exception.

\section{Dredge and Fill; Rivers and Harbors}

The CWA, Section 404, "Dredge and Fill Permitting," as amended, and the Rivers and Harbors Act (RHA) of 1899, Sections 9 and 10, "Construction Over and Obstruction of Navigable Waters of the United States," protect U.S. waters from dredging/ filling and construction activities by the permitting of such projects. Dredge-and-fill operations in U.S. waters are defined, permitted, and controlled through implementation of federal regulations in 33 CFR and 40 CFR.

In 2008, SRS had four open permits under the Nationwide Permits (NWPs) program (general permits under Section 404), as follows:

- Dam construction on an unnamed tributary to Fourmile Branch for the Mixed Waste Management Facility Groundwater Interim Measures project was completed in 2000 under NWP 38, 
"Hazardous Waste Cleanup." However, mitigation for the impact to wetlands was still pending in 2008 and must be addressed before the permit can be considered closed. The M\&O contractor has requested approval from DOE to use wetland mitigation bank credits to satisfy the mitigation issue and close the permit.

- Minor dredging of a sandbar at the mouth of the 681-3G Pumphouse canal was conducted and covered under NWP 19, "Minor Dredging." The work was completed in February.

- Installation of characterization wells in the wetlands near Joyce Branch and Mill Creek was covered under NWP 5, "Scientific Measurement Devices." The wells will be used to investigate the groundwater in wetlands adjacent to Joyce Branch and Mill Creek near R-Area. The project is scheduled for completion in 2009.

- A minor discharge of material for research purposes was authorized in May 2008 under NWP 18, "Minor Discharges. The material was placed in Steel Creek below the S.C. Highway 125 bridge and used by Savannah River National Laboratory (SRNL) as part of a remediation research project evaluating active caps in streams to remediate contaminants. An active cap is one that actively binds or sequesters contaminantsas opposed to a passive cap, which simply covers contaminants. The cap in this research project consisted of combinations of apatite, sand, organoclay, and a sugar-based polymer.

\section{Water Quality Certification}

Section 401, "Water Quality Certification," of the CWA is administered by SCDHEC to ensure the maintenance of water quality during dredge-and-fill projects. No water quality certifications (WQCs) were active at SRS during 2008.

\section{Construction in Navigable Waters}

SCDHEC Regulation 19-450, "Permit for Construction in Navigable Waters," protects South Carolina's navigable waters. The only state navigable waters at SRS are Upper Three Runs Creek (through the entire site) and Lower Three Runs Creek (upstream to the base of the PAR Pond Dam).

No navigable-waters permits were active at SRS during 2008.

\section{Federal Insecticide, Fungicide, and Rodenticide Act}

The Federal Insecticide, Fungicide, and Rodenticide Act controls the application of restricted-use pesticides at SRS through a state-administered certification program. The site complies with these requirements through Procedure 8.1, "Federal Insecticide, Fungicide, and Rodenticide Act Compliance for Use of Pesticides," of the Environmental Compliance Manual (3Q).

The SRS pesticide procedure provides guidelines for pesticide use and requires that applicators of restricted-use pesticides be state certified. Extensive revisions of the procedure have been incorporated in recent years to improve the efficiency of the site pesticide-application approval process. The most significant changes involved (1) dropping the requirement for a formal pesticide program plan for the application of unrestricted pesticides and (2) renewing emphasis on the importance of completing a Pesticide Activity Report (PAR) within 14 days (formerly 15) of any site pesticide application. Additional changes in the procedure-some involving expansion of the site's restricted-use pesticide list to include three pesticides formerly on the unrestricted list, but most editorial in nature - also have been completed.

The Environmental Protection Section completed a self-assessment in 2008 that emphasized the need for increased awareness of site spill prevention and control protocol-particularly with respect to pesticide applications. Site pesticide application personnel subsequently were notified of the importance of following the guidance established in applicable Environmental Compliance Manual procedures when they are preparing and applying pesticides at SRS.

\section{Clean Air Act}

\section{Regulation and Delegation}

The Clean Air Act (CAA) and the Clean Air Act Amendments (CAAA) of 1990 provide the basis for protecting and maintaining air quality. Though EPA still maintains overall authority for the control of air pollution, regulatory authority for all types of emission sources has been delegated to SCDHEC. Therefore, SCDHEC must ensure that its air pollution regulations are at least as stringent as the federal requirements. This is accomplished through 
SCDHEC Regulation 61-62, "Air Pollution Control Regulations and Standards." The various CAAA Titles covered by these SCDHEC regulations are discussed below.

\section{Title V Operating Permit Program}

Under the CAA, and as defined in federal regulations, SRS is classified as a "major source" and, as such, falls under the CAAA Part 70 Operating Permit Program. On February 19, 2003, SCDHEC's Bureau of Air Quality issued SRS its Part 70 Air Quality Permit (TV-0080-0041), with an effective date of April 1, 2003, and an expiration date of March 31, 2008. SRS submitted a permit application renewal September 18, 2007, as required by SC R61-62.70. The site expected to receive the new Part 70 Air Permit in 2008; however, due to prioritization issues with SCDHEC, renewal of the permit has been delayed until early 2010 - and the initial permit was extended. Until SCDHEC issues the permit renewal, SRS will continue to operate in accordance with requirements of the extended permit.

The Part 70 Air Quality Permit regulates both radioactive and nonradioactive toxic and criteria pollutant emissions from approximately 22 nonexempt emission units, with each emission unit having specific emission limits, operating conditions, and monitoring and reporting requirements. The permit also contains a listing, known as the InsignificantActivities List, identifying approximately 500 SRS sources that are exempt based on insignificant emission levels, or on equipment size or type. Two air construction permit applications were submitted to SCDHEC in 2006 in conjunction with SRS plans to simultaneously (1) install and operate a biomass boiler and an oil-fired boiler to provide steam to A-Area and (2) discontinue operation of the two aging A-Area coal-fired boilers. SRS received the permits in April 2007, and construction began on the biomass and oil-fired boilers in October 2007. Construction on the boilers was completed in 2008, and they began operating August 5 (oil-fired) and 6 (biomass). The two A-Area coal-fired boilers were shut down March 19 and September 13, 2008.

The renewed Title V permit for the D-Area Powerhouse (TV-0300-0036) was issued to SRS May 15, 2007, with an effective date of July 1, 2007, and an expiration date of June 30, 2012. In 2007, DOE-SR proposed replacement of the existing D-Area Powerhouse boilers with two new biomass cogeneration boilers more closely aligned with current and future steam demands. This proposed action would allow for decommissioning of the existing D-Area Powerhouse prior to its current Title $\mathrm{V}$ permit expiring June 30, 2012.

SCDHEC issued no revisions to the SRS Part 70 Air Quality Permit (TV-0080-0041) in 2008. One revision was issued by SCDHEC in 2008 to the 484-D Powerhouse Part 70 Air Quality Permit (TV-0300 0036) to incorporate an administrative change.

The Mixed Oxide Fuel Fabrication Facility (MFFF) - a part of the SRS Nuclear Nonproliferation Program - was issued an air construction permit (0080-0139CA) August 22, 2006. Construction of the MFFF began August 1, 2007, and continued throughout 2008.

Compliance with the SRS Part 70 Air Quality Permit conditions was last evaluated by SCDHEC in August 2008, as part of an Air Compliance Inspection. For results of the evaluation, refer to the "Assessments/ Inspections" section of this chapter, beginning on page 3-17.

\section{Notices of Violation (CAA)}

SCDHEC issued a Notice of Alleged Violation (NOAV) to SRS June 12 concerning a particulate matter (PM) exceedance related to the biennial stack test of the site's A-Area Boiler \#2 conducted February 20, 2008. During a presentation to SCDHEC, SRS provided credible evidence that (1) the boiler was operating within limits required by the permit, (2) the issuance of the NOAV by SCDHEC was not legally supportable, and (3) the only exceedance occurred during testing. SCDHEC agreed there was credible evidence that the boiler test was conducted at an operating level much higher than normal operating conditions, and agreed to include in any order language that SRS did not admit a violation. The parties continued to negotiate settlement of the dispute in 2008, and were expected to resolve it by consent in 2009.

\section{National Emission Standards for Hazardous Air Pollutants}

The National Emission Standards for Hazardous Air Pollutants (NESHAP) is a CAA-implementing regulation that sets air quality standards for air emissions containing hazardous air pollutants, such as radionuclides, benzene, and asbestos. 
NESHAP Radionuclide Program The current list of 187 hazardous air pollutants includes all radionuclides as a single item. Regulation of these pollutants has been delegated to SCDHEC; however, EPA Region 4 continues to regulate some aspects of NESHAP radionuclides.

NESHAP Radionuclide Program Subpart H of 40 CFR 61 was issued December 15, 1989, after which an evaluation of all air emission sources was performed to determine compliance status. DOE-SR and EPA Region 4 signed a Federal Facility Compliance Agreement (FFCA) October 31, 1991, providing a schedule to bring SRS's emissions monitoring into compliance with regulatory requirements. The FFCA was officially closed - and the site declared compliant_-by EPA Region 4 May 10, 1995. Subpart $\mathrm{H}$ was revised by EPA September 9, 2002, with an effective date of January 1, 2003. This revision added inspection requirements for existing SRS sources and allowed the use of ANSI N13.1-1999 for establishing monitoring requirements. SRS is performing all required inspections, has monitoring systems compliant with the regulation, and remains in compliance with Subpart H of 40 CFR 61.

During 2008, the maximally exposed individual effective dose equivalent, calculated using the NESHAP-required CAP88 computer code, was estimated to be $0.04 \mathrm{mrem}(0.004 \mathrm{mSv})$, which is 0.4 percent of the 10 mrem per year $(0.10 \mathrm{mSv}$ per year) EPA standard (chapter 6, "Potential Radiation Doses").

Compliance with 40 CFR 61, Subpart H, was last evaluated by SCDHEC in June 2008 as part of a radiological NESHAP inspection. For results of the evaluation, refer to the "Assessments/Inspections" section of this chapter, beginning on page 3-17.

NESHAP Nonradionuclide Program SRS uses many chemicals identified as toxic or hazardous air pollutants, but most of them are not regulated under the CAA or under federal NESHAP regulations. Except for asbestos, SRS facilities and operations do not fall into any of the "categories" listed in the original subparts. Under Title III of the federal CAAA of 1990, EPA in December 1993 issued a final list of hazardous air pollutant-emitting source categories potentially subject to maximum achievable control technology (MACT) standards.

On September 13, 2004, EPA finalized a MACT rule that applied to the coal-fired steam boilers at the
784-A and 484-D powerhouse facilities. The rule, "National Emission Standards for Hazardous Air Pollutants for Industrial, Commercial, and Institutional Boilers and Process Heaters" (Boiler MACT), had a compliance date of September 13, 2007, and required facilities to meet more stringent emissions limits dealing with PM, mercury, and hydrogen chloride emissions. During 2006, 484-D Powerhouse Facility personnel prepared to conduct the necessary testing during the 2007-2008 timeframe to demonstrate compliance with the new emission limits without the significant expenditure of capital funds. In June 2006, a MACT extension request was submitted to SCDHEC's Bureau of Air Quality requesting a one-year extension from the September 2007 compliance date so SRS could replace the aging A-Area boilers with a smaller wood-fired boiler and an oil-fired boiler capable of meeting the lower MACT emission limits. That compliance extension request was approved by SCDHEC September 5, 2006. Then, on July 30, 2007, the U.S. Court of Appeals for the District of Columbia vacated the Boiler MACT, thereby leaving it up to each state to enforce the rule. The State of South Carolina-one of the few states that elected to proceed with implementation of the rule-decided to give all facilities in the state a one-year extension until September 12,2008 , to comply. In May 2008, SCDHEC provided an additional 24 months - until September 13, 2010 - for the facilities to comply.

NESHAP Asbestos Abatement Program SRS began its asbestos abatement program in 1988 and continues to manage asbestos-containing material (ACM) by "best management practices." Site compliance in asbestos abatement, as well as demolitions, falls under South Carolina and federal regulations, including South Carolina Regulation 61-86.1 ("Standards of Performance for Asbestos Projects") and 40 CFR 61, Subpart M ("National Emission Standards for Hazardous Air Pollutants - Asbestos").

SCDHEC finalized extensive revisions to 61-86.1 during 2008. The change that most affected SRS was a measure requiring a follow-up analysis using transmission electron microscopy (TEM) of at least one of three bulk samples should all three samples test negative for the presence of asbestos when using customary polarized light microscopy. RI\&ES personnel secured a laboratory to perform the TEM analyses, thus enabling the site to comply with the new requirement. Site Procedure 4.14 ("Asbestos Management Program") of the 3Q Manual will be 
revised in 2009 to reflect the TEM requirement.

During 2008, SRS personnel removed and disposed of an estimated 121 square feet and 1,231 linear feet of friable (regulated) asbestos-containing material. SRS personnel also removed an estimated 5,399 square feet, 8,530 linear feet, and 486 cubic feet of nonfriable (unregulated) asbestos-containing material.

Radiologically contaminated asbestos waste was disposed of at the SRS E-Area low-level vaults, engineered trenches, and slit trenches, which are authorized by SCDHEC as asbestos waste disposal sites. Nonradiological asbestos waste was disposed of at the Three Rivers Solid Waste Authority Landfill and the construction and demolition debris (C\&D) Landfill (632-G), both of which also are SCDHECapproved asbestos waste landfills.

\section{Accidental Release Prevention Program}

Under Title III of the CAAA, EPA established a program for the prevention of accidental releases of large quantities of hazardous chemicals. As outlined in Section 112(r), any facility that maintains specific hazardous or extremely hazardous chemicals in quantities above specified threshold values must develop a risk management program (RMP). The RMP establishes methods that will be used for the containment and mitigation of large chemical spills. No such accidental releases occurred at SRS during 2008.

SRS maintains hazardous and extremely hazardous chemical inventories below the threshold value. This cost-effective approach minimizes the regulatory burden of 112(r) but does not eliminate any liability associated with the general duty clause, as stated in 112(r)(1). No reportable 112(r)-related hazardous or extremely hazardous chemical releases occurred at SRS in 2008.

EPA issued a revision to its RMP final rule in 2004, changing reporting requirements in its chemical accident prevention regulations. Chemical facilities subject to these regulations now are required to submit significant-chemical-accident information and emergency contact information. These changes seek to improve and assist federal, state, and local risk management programs in implementing the new homeland security measures. As indicated earlier, SRS maintains hazardous and nonhazardous chemical inventories below threshold values such that there are no associated EPA RMP reporting requirements.

\section{Ozone-Depleting Substances}

Title VI of the CAAA of 1990 addresses stratospheric ozone protection. This law requires that EPA establish regulations to phase out the production and consumption of ozone-depleting substances (ODSs).

Several sections of Title VI of the CAAA of 1990, along with recently established EPA regulations found in 40 CFR 82, apply to the site. The ODSs are regulated in three general categories, as follows:

- Class I substances - chlorofluorocarbons (CFCs), Halons, carbon tetrachloride, methyl chloroform, methyl bromide, and hydrobromofluorocarbons (HBFCs)

- Class II substances - hydrochlorofluorocarbons (HCFCs)

\section{- $\quad$ Substitute substances}

The "Savannah River Site Refrigerant Management Plan," completed and issued in September 1994, provides guidance to assist SRS and DOE in the phaseout of CFC refrigerants and equipment. SRS has reduced CFC refrigerant usage in large ODS emission sources more than 99 percent compared to 1993 baseline data used in the September 1994 Plan.

The SRS CAAA of 1990 Title V operating air permit application includes ODS emission sources. All large (greater than or equal to 50-pound charge) heating, ventilation, and air conditioning/chiller systems for which there are recordkeeping requirements are included as fugitive emission sources.

SRS is phasing out its use of Halon as part of a goal to eliminate the use of Class I ODSs by 2010 "to the extent economically practicable." A Halon 1301 management plan (F-ESR-G-00120, November 16, 2005) and schedule have been developed by Fire Protection Services to help meet DOE's goal. The plan includes an SRS Halon 1301 fire suppression system inventory that identifies systems in operation, systems abandoned in place, and systems that have been dismantled and taken to the DOE complex's Halon repository, located at SRS.

Halon 1301 total inventory on site increased slightly 
from 71,130 pounds in 2007 to 71,167 pounds in 2008 . The site had an inventory of 51,760 pounds of stored Halon 1301 at the end of 2008. In addition, 19,407 pounds were contained in the 85 operating systems at the end of 2008 - the same as at the end of 2007 (down from 111 systems in 2002).

\section{Air Emissions Inventory}

SCDHEC Regulation 61-62.1, Section III ("Emissions Inventory"), requires compilation of an air emissions inventory to locate all sources of air pollution and to define and characterize the various types and amounts of pollutants. To demonstrate compliance, SRS personnel in 1993 conducted the initial comprehensive air emissions inventory, which identified approximately 5,300 radiological and nonradiological air emission sources. Source operating data and calculated emissions from 1990 were used initially to establish the SRS baseline emissions and to provide data for air dispersion modeling. In 2006, a rerun of the air dispersion modeling accompanied the site's Title $\mathrm{V}$ permit renewal application. This modeling was required to demonstrate sitewide compliance with Regulation 61-62.5, Standards No. 2 ("Ambient Air Quality Standards") and No. 8 ("Toxic Air Pollutants").

Regulation 61-62.1, Section III, which was revised in August 2005, requires that air emissions inventory data be updated and recorded annually but reported to SCDHEC on a specific reporting frequency - either an annual cycle for "Type A" sources or a 3-year cycle for "Type B" and "Nonattainment Area" sources-based on "minimum reporting thresholds." The threshold values depend on the actual tons per year of specific criteria pollutants.

SRS, under Title V Permit TV-0080-0041, is classified as a Type B source, required to report only every third year, thus reducing the cost burden associated with annual emissions inventories for sources with moderate emission rates. However, the acquired D-Area Powerhouse (co-located at SRS), under Title V Permit TV-0080-0044, is a Type A source that must report actual emissions annually. Both facilities (i.e., "SRS" and "D-Area Powerhouse") are required to compile and report CY 2008 emissions to SCDHEC by March 31, 2009. CY 2007 emissions were submitted to SCDHEC March 31, 2008, only for the D-Area Powerhouse, as required.

During 2008, the site collected CY07 operating data for permitted and other significant sources in accordance with SRS procedures and guidelines. Because data collection for all SRS sources begins in January for the preceding year and requires up to 6 months to complete, the 2008 site environmental report contains emissions data for CY 2007. These data were used to generate the site's Title V Permit renewal application. Compilation of 2008 data will be completed in 2009 and documented in the $S R S$ Environmental Report for 2009.

\section{Toxic Substances Control Act}

The Toxic Substances Control Act (TSCA) gives EPA comprehensive authority to identify and control chemical substances manufactured, imported, processed, used, or distributed in commerce in the United States. Reporting and record keeping are mandated for new chemicals and for any chemical that may present a substantial risk of injury to human health or the environment.

Polychlorinated biphenyls (PCBs) have been used in various SRS processes. The use, storage, and disposal of these organic chemicals are specifically regulated under 40 CFR 761, which is administered by EPA. SRS has a well-structured PCB program that complies with this TSCA regulation, with DOE orders, and with site policies.

The site's 2007 PCB document log was completed in full compliance with 40 CFR 761, and the 2007 annual report of onsite $\mathrm{PCB}$ disposal activities was submitted to EPA Region 4 in July 2008. The disposal of nonradioactive $\mathrm{PCBs}$ routinely generated at SRS is conducted at EPA-approved facilities within the regulatory period. For some forms of radioactive PCB wastes, disposal capacity is not yet available, and the wastes must remain in long-term storage. Such wastes are held in TSCA-compliant storage facilities in accordance with 40 CFR 761.

\section{Endangered Species Act}

The Endangered Species Act of 1973, as amended, provides for the designation and protection of wildlife, fish, and plants in danger of becoming extinct. The act also protects and conserves the critical habitats on which such species depend.

Several threatened and endangered species exist at SRS, including the wood stork, the red-cockaded woodpecker, the shortnose sturgeon, the pondberry, and the smooth purple coneflower. Although the bald eagle is no longer on the endangered species list, 
it is still protected under the Bald and Golden Eagle Protection Act. Programs are in place to enhance the habitat and survival of such species.

In 2008, as part of the Natural Resource Management Plan, the USDA Forest Service-Savannah River (USFS-SR) developed a threatened and endangered species biological evaluation (TES BE) for the red-cockaded woodpecker and the smooth purple coneflower. The TES BE is being reviewed by DOE as part of the management plan. Also, two biological evaluations were conducted during the year for forestry-related activities. The timberrelated BEs are being evaluated by the U.S. Fish and Wildlife Service to determine if there are any adverse or beneficial impacts as a result of timber prescriptions (i.e., intervention actions taken in the present to achieve a desired future condition for the forest).

\section{National Historic Preservation Act}

The National Historic Preservation Act (NHPA) of 1966, Section 106, governs archaeological and historical resources. SRS ensures that it is in compliance with the NHPA through several processes. The Cold War Programmatic Agreement and the SRS Cold War Built Environment Cultural Resource Management Plan are in place and being implemented. The site's artifact selection team - which includes DOE, Savannah River Nuclear Solutions, LLC, (SRNS), and the University of South Carolina's Savannah River Archaeological Research Program (SRARP) - meets monthly and is responsible for overseeing the selection, collection, and curation of Cold War-era artifacts from buildings prior to decommissioning and demolition activities.

SRS also helps ensure that it remains in compliance with NHPA through its Site Use Program. All locations being considered for activities such as construction are evaluated by SRARP personnel to ensure that archaeological or historic sites are not impacted. Reviews of timber compartment prescriptions include surveying for archaeological resources and documenting areas of importance with regard to historic and prehistoric significance.

SRARP personnel reviewed 26 site-use permit application packages during FY 2008, of which 16 proposed land modifications resulted in the need to survey 245 acres (15.2 percent) of the total survey coverage for FY08. The remaining site-use packages were found to have no activities of significant impact in terms of the NHPA. SRARP personnel also surveyed 1,372 acres ( 84.8 percent) of the total survey area coverage in 2008 in support of onsite forestry activities.

Thirty-two surveys were conducted totaling 1,617 acres and consisting of 16 Site Use Application Surveys and 16 Timber Compartment Prescription Surveys. During these surveys a total of 2,875 shovel test pits were dug of which 165 had positive results. These investigations identified 25 new archaeological sites - and resulted in revisits to seven previously recorded sites for cultural resources management within the 1617 acres.

In compliance with NHPA, artifacts recovered through daily compliance activities and the analysis of artifacts recovered during Phase III investigations of site 38AK155 (located within the MOX facility footprint) must be curated. A total of 2,901 artifacts were curated during FY 2008 by SRARP.

\section{Floodplains and Wetlands}

Under 10 CFR, Part 1022 ("Compliance with Floodplains and Wetlands Environmental Review Requirements"), DOE establishes policies and procedures for implementing its responsibilities in terms of compliance with Executive Orders 11988 ("Floodplain Management") and 11990 ("Protection of Wetlands"). Part 1022 includes DOE policies regarding the consideration of floodplains/wetlands factors in planning and decision making. It also includes DOE procedures for identifying proposed actions involving floodplains/wetlands, providing early public reviews of such proposed actions, preparing floodplains/wetlands assessments, and issuing statements of findings for actions in floodplains. A floodplain/ wetland assessment was performed for the Biomass Cogeneration and Heating Facility in 2008. The generating facility would have an NPDES discharge into Upper Three Runs Creek. The creek and the adjacent wetlands and floodplain would be affected by the project and would require a U.S. Army Corps of Engineers permit and SCDHEC 401 WQC and Navigable Waters Permit.

\section{Executive Order 11988}

Executive Order 11988 ("Floodplain Management") was established to avoid long- and short-term impacts associated with the occupancy and modification of floodplains. The evaluation of impacts to SRS floodplains is ensured through the NEPA Evaluation Checklist and the site-use system. Site-use ap- 
plications are reviewed for potential impacts by the $\mathrm{M} \& \mathrm{O}$ contractor, DOE-SR, the USFS-SR, and the Savannah River Ecology Laboratory (SREL), as well as by professionals from other organizations.

\section{Executive Order 11990}

Executive Order 11990 ("Protection of Wetlands") was established to mitigate adverse impacts to wetlands caused by the destruction and modification of wetlands, and to avoid new construction in wetlands wherever possible. Avoidance of impact to SRS wetlands is ensured through the site-use process, various departmental procedures and checklists, and project reviews by the SRS Wetlands Task Group. Many groups and individuals - including scientists from SRNL, SREL, and RI\&ES - review site-use applications to ensure that proposed projects do not impact wetlands.

\section{Environmental Release Response and Reporting}

\section{Response to Unplanned Releases}

RI\&ES personnel respond to unplanned environmental releases, both radiological and nonradiological, upon request by area operations personnel. No unplanned environmental releases occurred at SRS in 2008 that required the sampling and analytical services of RI\&ES.

\section{Occurrences Reported to Regulatory Agencies}

Federally permitted releases comply with legally enforceable licenses, permits, regulations, or orders. If a nonpermitted release to the environment of a reportable quantity or more of a hazardous substance (including radionuclides) occurs, CERCLA requires notification of the National Response Center. Reportable quantities - not to be confused with threshold values, as defined by EPCRA Section 313 - are those quantities of a hazardous substance greater than or equal to values specified in table 302.4 ("Designation of Hazardous Substances") of 40CFR, Part 302 ("Designation, Reportable Quantities, and Notification").
Also, the CWA requires that the National Response Center be notified if an oil spill causes a "sheen" on navigable waters, such as rivers, lakes, or streams. Oil spill reporting has been reinforced with liability provisions in the CERCLA National Contingency Plan. SRS has had no CERCLA-reportable releases since 1999.

No notifications required by CERCLA or SCDHEC Memoranda of Understanding had to be made by SRS during 2008. The site recorded and cleaned up the following spills that did not require reporting under CERCLA or to SCDHEC: 14 chemical, two radioactive wastewater, five sewage, and 88 petroleum products.

EPCRA (40 CFR 355.40) requires that reportable releases of extremely hazardous substances or CERCLA hazardous substances be reported to any local emergency planning committees and state emergency response commissions likely to be affected by the release. No EPCRA-reportable releases occurred at SRS in 2008.

\section{Site Item Reportability and Issues Management Program}

The Site Item Reportability and Issues Management (SIRIM) program, mandated by DOE Order 232.1A ("Occurrence Reporting and Processing of Operations Information"), is designed to ". . . establish a system for reporting of operations information related to DOE-owned or -operated facilities and processing of that information to provide for appropriate corrective action ...." It is the intent of the order that DOE be "... kept fully and currently informed of all events which could (1) affect the health and safety of the public; (2) seriously impact the intended purpose of DOE facilities; (3) have a noticeable adverse effect on the environment; or (4) endanger the health and safety of workers."

Of the 149 SIRIM-reportable events in 2008, three were categorized as environmental, involving allegations of violations at the $\mathrm{G}-10$ Outfall, the $\mathrm{K}-12$ Outfall, and the A-Area power plant. See the Clean Water Act section of this chapter on page 3-8 for a discussion of the $\mathrm{G}-10$ and $\mathrm{K}-12$ Outfalls, and the Clean Air Act section on page 3-10 regarding the A-2 Boiler at the A-Area power plant. SCDHEC did 
not seek an administrative hearing on any of these matters to determine if a violation occurred.

\section{Assessments/Inspections}

The SRS environmental program is overseen by a number of organizations, both outside and within the DOE complex. In 2008, the site's environmental appraisal program consisted of self and independent assessments. The program ensures the recognition of noteworthy practices, the identification of performance deficiencies, and the initiation and tracking of associated corrective actions until they are satisfactorily completed. The primary objectives of the assessment program are to ensure compliance with regulatory requirements and to foster continuous improvement. The program - an integral part of the site's ISMS - supports the SRS Environmental Management System (EMS), which continues to meet the standards of International Organization for Standardization Standard 14001. (ISO 14000 is a family of voluntary environmental management standards and guidelines.) The Site Tracking, Analysis, and Reporting (STAR) is a database used for scheduling self-assessments as well as documenting results and any issues or concerns identified, tracking corrective actions to closure, and trending accumulated data for process improvement.

The M\&O contractor conducted several environmental program-level assessments in 2008. The titles of the self-assessment titles, the media (in parentheses), and brief summaries of the results are as follows:

- ESS Assessment of NEPA Process Integration into the SRS Environmental Management System (EMS) (National Environmental Policy Act) This Environmental Services Section (ESS) selfassessment was conducted -January 31 through April 23. Its purpose was to determine the extent of NEPA process integration into the SRS EMS. The assessment identified four opportunities for improvement (OFIs) and one finding. The OFIs included the following: (1) consistently track and monitor NEPA of commitments; (2) develop centralized, continuously updated comprehensive environmental database; (3) identify resources required to implement NEPA's "adaptive man- agement" approach; and (4) consistently implement use of the formal site selection process for major new missions. The finding related to the lack of EMS support for using NEPA's "adaptive management" approach (i.e., predict, mitigate, implement, monitor, and adapt). Corrective actions for the observations and finding were identified, initiated, and completed.

- IWT/NPDES Permit Condition Cross-Walk (Surface Water Quality) - This self-assessment was conducted March 15 through May 14. Its purpose was to conduct an industrial wastewater treatment (IWT)/NPDES Permit Condition Cross-Walk. It identified the following items and/ or areas requiring improvement: Documentation involving the facility's industrial wastewater permitting file appears incomplete. A corrective action for the item was identified and documented in STAR and tracked to completion.

- Polychlorinated Biphenyls Management and Control (Toxic and Chemical Materials) - This self-assessment was conducted May 19-29. Its scope included a review of PCB activities within selected site organizations. The specific organizations selected for personnel interviews and/or other reviews were: (1) Waste Management Area Project (WMAP); (2) the ESS group supporting F-Area Operations; (3) the Site Deactivation and Decommissioning (SDD) organization; and (4) SRNL. The assessor gathered information for this assessment via document review, personnel interviews, PCB waste storage facilities inspections, and PCB container inspections. Four OFIs to the site-level program were noted, including PCB Management Manual and "Waste Identification Form" revisions. Identified issues were documented in STAR and tracked to completion.

- ESS Annual Environmental Audit Review 2008 "Pre-CEI" (Waste Management) - This selfassessment was conducted February 5 through April 2. Its scope included the ESS performance of its annual environmental audit review of the site's solid and hazardous waste management, commonly known as the "Pre-CME" or "Pre-CEI". ESS attempted to review the site as SCDHEC and EPA inspectors would look at it. 
This review gives site personnel a feel for how the Compliance Evaluation Inspection (CEI), which evaluates compliance with solid and hazardous waste management regulations, will be conducted by the regulators. The following concerns requiring improvement were identified: issues with documentation in inspection records, contingency plans, and training. Additional areas of concern within hazardous waste management include open containers, unlabeled containers, and secondary containment. Actions taken associated with the pre-CEI were identified, tracked, and completed in STAR.

- Nonhazardous Solid Waste (Waste Management) - This self-assessment was conducted July 16-22. Its scope was to determine if prohibited materials, as defined by 3Q ECM 6.2, Rev. 13, are being placed into waste containers transported to the North Augusta Material Recovery Facility. The focus was on five of the 16 listed prohibited materials, which were labeled as radioactive, hazardous waste, fluorescent lamps, lead-acid batteries, and classified material (equipment or documents that contain or reveal classified information, as defined by Executive Order 12958, "Classified National Security Information"). Three SRS areas were assessed-SRNL, SREL, and B-Area Laboratory. Also reviewed was the North Augusta Material Recovery Facility. The assessors gathered information for this self-assessment by reviewing documents, interviewing cognizant personnel, and inspecting both solid waste collection containers (dumpsters) and the North Augusta Material Recovery Facility. All personnel interviewed were knowledgeable of the requirements and procedures regarding prohibited materials and solid waste management. No findings were identified.

- Environmental Management Functions SelfAssessment (Environmental Management Functions) - This self-assessment was conducted September 8-18. Its purpose was to ensure that SRNS and subcontractor organizations apply EMS principles and requirements in conducting activities associated with environmental protection. This self-assessment looked at formalized controls based on DOE directives, environmental permits, and applicable federal, state, and local regulations. No findings were identified; however, three observations were recorded as OFIs, which included resource needs and responsibility assignments. Corrective actions for the observations were identified and documented in STAR and tracked to completion.

- Groundwater Monitoring-Well Network (Groundwater) - This self-assessment was conducted during the period of October 10-30. Its scope included evaluation of the sitewide groundwater monitoring well network that is in place so that the effects of operations on groundwater quality can be determined and documented. The selfassessment involved a review of procedures and permits, and of well installation, maintenance, and abandonment records. The data engineer responsible for loading well data into the site's database was interviewed, as was the well maintenance coordinator. No OFIs or findings resulted from this assessment.

- Environmental Surveillance - Groundwater Monitoring Program (Groundwater) - This self-assessment was conducted October 20-30. Its scope included evaluation of the program that monitors SRS groundwater. The self-assessment also included a review of procedures, DOE orders, the SRS Groundwater Protection Program, and the Environmental Restoration Data Management System (ERDMS) Data Management Plan. A groundwater monitoring program is being implemented. It is made up of multiple site-specific monitoring programs specifically tailored to the requirements of individual regulated units. These individual programs operate under a common set of procedures and feed data into a common database (the ERDMS). The SRS Groundwater Protection Program describes the integration of the individual programs into a sitewide system. No findings resulted from this self-assessment, but two OFIs were identified. Corrective actions for the OFIs were identified as revisions of the SRS Groundwater Protection Plan. This corrective action has been initiated.

- Air Emissions Inventory - Completed in July, this effort focused on the adequacy and effectiveness of policies, procedures, and programs, including the Air Information Reporting System (AIRS) database for completing the Air Emissions Inventory. Inquiries covered compliance with the governing procedure, timeliness and accuracy of AIRS updates, verification of select emission factors, and control measures for access/updates to the AIRS database. No findings were noted; however, activities were initiated to identify and evaluate commercially available off-the-shelf 
software products to improve data maintenance and upkeep, ensure more accurate emission estimates, reduce omissions and complacency, and increase the level of data ownership/ responsibility.

SCDHEC and EPA personnel conducted external inspections and audits of the SRS environmental program for regulatory compliance. Agency representatives performed several comprehensive compliance inspections and audits in 2008, as follows:

- $\quad$ RCRA Compliance Evaluation Inspection - The RCRA compliance evaluation inspection was conducted by SCDHEC June 2-6. A July 22 SCDHEC letter noted, "The facility appeared to be in compliance with all applicable requirements. You are to be commended for your excellent hazardous waste management program."

- Annual Underground Storage Tank InspectionSCDHEC inspected the site's USTs August 20. All were found to be in compliance with applicable regulations for the sixth straight year.

- 632-G C\&D Landfill, 288-F Ash Landfill, and 488-4D Ash Landfill Inspections - SCDHEC conducted quarterly inspections of the $632-\mathrm{G}$ C\&D, the 288-F Ash, and the 488-4D Ash landfills; the facilities were found to be satisfactory, with no observed deficiencies.

- Z-Area Saltstone Solid Waste Landfill Inspections - The Saltstone Disposal Facility inspections continued to be completed on a weekly basis. Moisture areas were observed on the walls of the facility's Vault 4, and were reported to SCDHEC in accordance with the facility's contingency plan. (NOTE: "Moisture areas" are areas on the external walls of the facility's cells that appear damp due to a combination of saltstone shrinkage from curing, bleed, and process water accumulation at the inner cell walls, and hydrostatic pressure that causes the water to weep through preexisting construction cracks. Such moisture areas are not areas of free-flowing liquid.)

- Interim Sanitary Landfill - SCDHEC personnel conducted an annual post-closure inspection September 9, and the landfill was found to be satisfactory, with no observed deficiencies.

- Groundwater Comprehensive Monitoring Evalu- ation - SCDHEC conducted an unannounced RCRA inspection of SRS's groundwater program March 19-24. No deficiencies or permit violations were cited.

- $\quad$ Site Radionuclide NESHAP Compliance Audit - SCDHEC's Bureau of Air Quality conducted an air compliance audit June 17. The audit's purpose was to verify that the site's NESHAP Radionuclide Program is in compliance with 40 CFR 61 Subpart H requirements, and with the monitoring, reporting, and recordkeeping requirements contained in the Part 70 Air Quality Permit. One issue, based on a selfreported condition, was identified that related to the late submittal of the relative accuracy testing of the continuous-flow measurement system at F-Canyon. The testing was completed on time, but the report was not submitted to SCDHEC within the 30 days required by the permit. SRS has received a letter from SCDHEC indicating that further evaluation of the late submission is ongoing. No enforcement action was taken in 2008 .

- Quarterly Inspections of SRS Bottled Water Facility - SCDHEC's Division of Food Protection conducted quarterly inspections of the SRS Bottled Water Facility until the plant was closed formally in September. Prior to the closure, results from routine bacteriological analyses and annual complete chemical analyses met SCDHEC and FDA water quality standards.

- $\quad$ Site and D-Area Air Compliance Audit-SCD HEC's Bureau of Air Quality conducted an air compliance audit August 18-20. The audit's purpose was to verify that SRS and the D-Area Powerhouse were in compliance with applicable regulations, including monitoring, reporting, and recordkeeping requirements contained in both Part 70 Air Quality Permits.

- Annual NPDES Wastewater Program Inspection-SCDHEC inspected the site's wastewater facilities (e.g., outfalls) in March. All were found to be in compliance with applicable regulations.

\section{Environmental Training}

The SRS environmental training program identifies training needs and appropriate training settings to teach job-specific skills that protect the employee and the environment, in addition to satisfying regula- 
Table 3-4

SRS Construction and Operating Permits, 2004-2008

\begin{tabular}{|c|c|c|c|c|c|}
\hline \multirow[t]{2}{*}{ Type of Permit } & \multicolumn{5}{|c|}{ Number of Permits } \\
\hline & 2004 & 2005 & 2006 & 2007 & 2008 \\
\hline Air & 3 & 1 & $3^{a}$ & $5^{\mathrm{a}}$ & 5 \\
\hline U.S. Army Corps of Engineers Nationwide Permit & 3 & 4 & 5 & 5 & 4 \\
\hline Domestic Water & 203 & 207 & 207 & 207 & 170 \\
\hline Industrial Wastewater & 56 & 63 & 70 & 70 & 70 \\
\hline NPDES Discharge & 1 & 1 & 2 & 2 & 2 \\
\hline NPDES No Discharge & 1 & 1 & 1 & 1 & 1 \\
\hline NPDES Stormwater & 2 & 2 & 2 & 2 & 2 \\
\hline NPDES Construction Stormwater Grading Permit & $\mathrm{N} / \mathrm{A}$ & 13 & 9 & 10 & 11 \\
\hline RCRA Hazardous Waste & 1 & 1 & 1 & 1 & 1 \\
\hline RCRA Solid Waste ${ }^{b}$ & 4 & 4 & 3 & 4 & 4 \\
\hline RCRA Underground Storage Tank & 7 & 7 & 7 & 7 & 7 \\
\hline Sanitary Wastewater & 104 & 106 & 106 & 106 & 98 \\
\hline SCDHEC 401 & 0 & 0 & 0 & 1 & 0 \\
\hline SCDHEC Navigable Waters & 0 & 0 & 0 & 1 & 0 \\
\hline Underground Injection Control & 18 & 21 & 14 & 14 & 15 \\
\hline Totals & 403 & 431 & 430 & 436 & 390 \\
\hline
\end{tabular}

tory training requirements. This process ensures that personnel whose actions could have environmental consequences are properly trained and made aware of their responsibilities to protect the environment, workers, and the public. General environmental awareness training is provided to all employees of SRS via initial General Employee Training (GET) which subsequently is reinforced annually through Consolidated Annual Training (CAT). Specialized training opportunities are developed by and offered through a centralized training organization that relies heavily upon the functional-area subject matter expertise within the environmental organization for the development of environmental and waste management curriculum. Regularly scheduled classes in this program cover such topics as Environmental Laws and Regulations, the Hazardous Waste Worker, Hazardous and Radiological Waste Characterization, and the Environmental Compliance Authority course. A selftaught Environmental Laws and Regulations courseavailable for technical personnel-is updated annually by environmental subject matter experts. More than 60 environmental program-related training courses are listed in the site training database, and individual organizations schedule and perform other facilityspecific, environment-related training to ensure that 
operations and maintenance personnel, as well as environmental professionals, have the knowledge and skills to perform work safely and in a manner that protects the environment in and around SRS.

\section{Environmental Permits}

SRS had 390 construction and operating permits in 2008 that specified operating levels for each permit- ted source. Table 3-4 summarizes the permits held by the site during the past 5 years. These numbers reflect only permits obtained by the $\mathrm{M} \& \mathrm{O}$ contractor for itself and for other SRS contractors that requested assistance in obtaining permits. The numbers include some permits that were voided or closed during the calendar year (2008).

Editor's note: The "Environmental Compliance" chapter is unique in that its number of contributing authors is far greater than the number for any other chapter in this report. Space/layout constraints prevent us from listing all of them and their organizations on the chapter's first page, so we list them here instead. Their contributions, along with those of the report's other authors, continue to play a critical role in helping us produce a quality document-and are very much appreciated.

\section{Savannah River Nuclear Solutions}

Brent Blunt, RI\&ES

Paul Carroll, RI\&ES

Vivian Cato, RI\&ES

Bill Debruhl, S\&S FP

Keith Dyer, RI\&ES

Tim Faugl, RI\&ES

Don Frazier, RI\&ES

John Harley, WME

Mike Hughes, RI\&ES
Ginger Humphries, RI\&ES

Jim Koch, RI\&ES

Linn Liles, RI\&ES

Jeff Lintern, RI\&ES

Bob Lorenz, RI\&E

Nancy Lowry, RI\&ES

Bill Maloney, RI\&ES

Al Mamatey, RI\&ES

Lynn Martin, RI\&ES
Shelia McFalls, RI\&ES

Tim McCormick, RI\&ES

Hal Morris, RI\&ES

Vern Osteen, RI\&ES

Bill Payne, RI\&ES

Barry Shedrow, RI\&ES

Cary Stevens, RI\&ES

Dan Wells, RI\&ES

Michele Wilson, RI\&ES

\section{Washington Savannah River Company}

Ron Campbell, EC\&WM

Keith Liner, WD 

Effluent Monitoring

Paul Carroll, Donald Padgett, and Monte Steedley

Regulatory Integration \& Environmental Services

Timothy Jannik

Savannah River National Laboratory

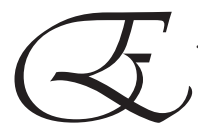

ffluent monitoring at the Savannah River Site (SRS) is conducted to demonstrate compliance with applicable standards and regulations. Site effluent monitoring activities are divided into radiological and nonradiological programs. A complete description of sampling and analytical procedures used for effluent monitoring by the Environmental Monitoring Services group of the site's Regulatory Integration \& Environmental Services organization can be found in sections 1101-1111 of the Savannah River Site Environmental Monitoring Program, WSRC-3Q1-2, Volume 1, Revision 4, [SRS EM Program, 2002]. A summary of data results is presented in this chapter; more complete data can be found in tables on the CD included with this report.

\section{Radiological Monitoring}

Radiological effluent monitoring results are a major component in determining compliance with applicable dose standards. SRS management philosophy ensures that potential exposures to members of the public and to onsite workers are kept as far below regulatory standards as is reasonably achievable. This philosophy is known as the "as low as reasonably achievable" (ALARA) concept.

SRS airborne and liquid effluents that potentially contain radionuclides are monitored at their points of discharge by a combination of direct measurement and/or sample extraction and analysis. Each operating facility maintains ownership of, and is responsible for, its radiological effluents.

Unspecified alpha and beta radiation releases (the measured gross activity minus the identified individual radionuclides) in airborne and liquid releases are large contributors - on a percentage basis - to offsite doses, especially for the airborne pathway from diffuse and fugitive releases (see definitions below).

The unspecified alpha and beta releases are listed separately in the effluent release tables. They conservatively include naturally occurring radionuclides such as uranium, thorium, and potassium-40, as well as small amounts of unidentified manmade radionuclides. For dose calculations, the unspecified alpha releases were assigned the plutonium-239 dose factor, and the unspecified beta releases were assigned the strontium-90 dose factor (chapter 6, "Potential Radiation Doses").

\section{Airborne Emissions}

Process area stacks that release, or have the potential to release, radioactive materials are monitored continuously by applicable online monitoring and/or sampling systems [SRS EM Program, 2002].

Depending on the processes involved, discharge stacks also may be monitored with "real-time" instrumentation to determine instantaneous and cumulative atmospheric releases to the environment. Tritium is one of the radionuclides monitored with continuous real-time instrumentation.

The following effluent sampling and monitoring changes were made during 2008:

- Sampling was changed from weekly to twice a year at the $299-\mathrm{H}$ building stack (also referred to as the $299-\mathrm{H}$ decon facility stack), based on the potential impact category.

- Baseline sampling was conducted at the 241278H Caustic Extraction Facility and set at a quarterly frequency for the new facility, based on the potential impact category.

- Sampling was discontinued at the 105-C Stack Decon Exhaust because no equipment was decontaminated at the facility during 2008. 


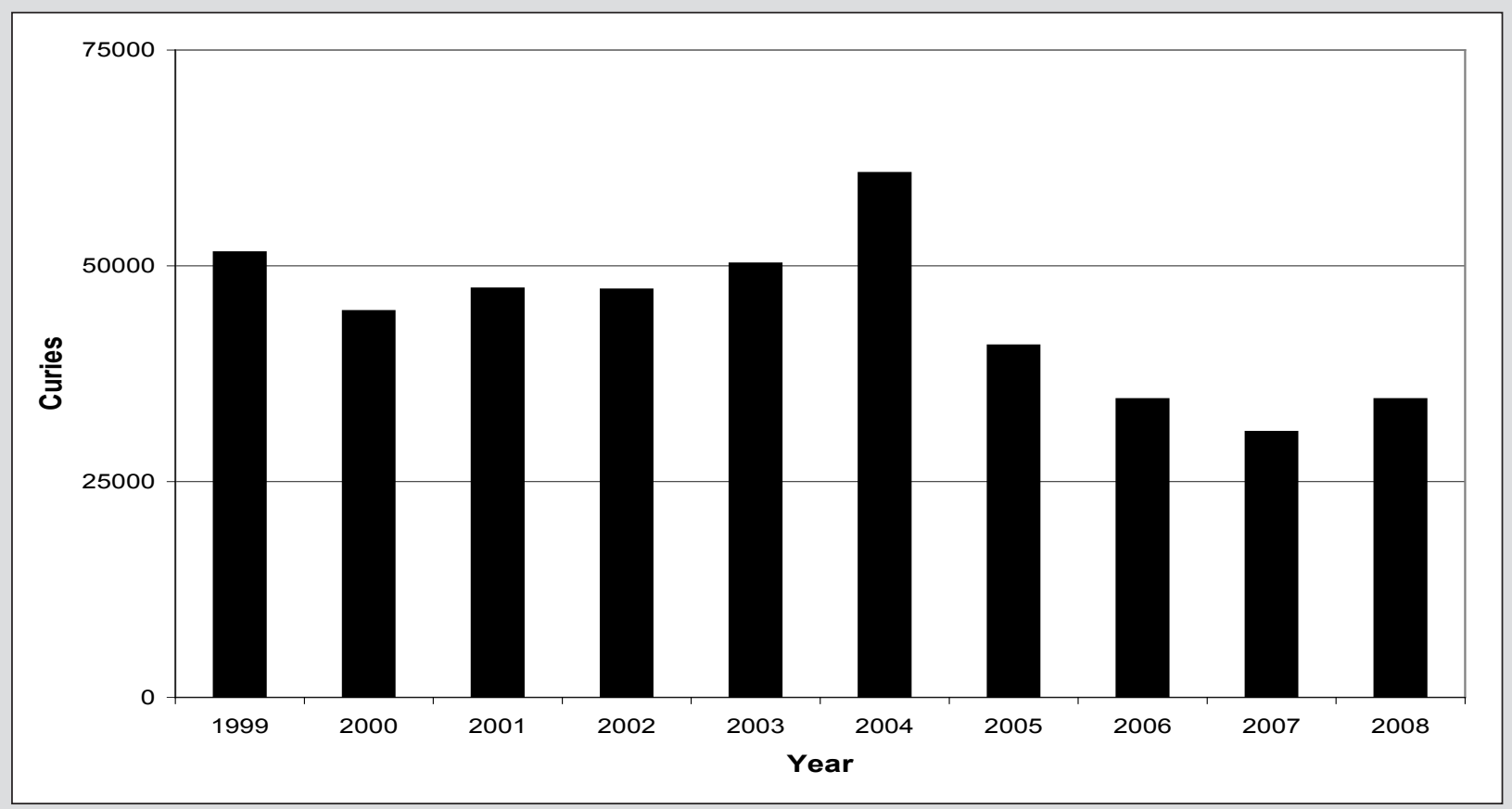

Figure 4-1 Ten-Year History of SRS Annual Atmospheric Tritium Release

\section{Diffuse and Fugitive Sources}

Estimates of radionuclide releases from unmonitored diffuse and fugitive sources are calculated on an annual basis and are included in the SRS radioactive release totals. A diffuse source is defined as an area source, such as a pond or disposal area. A fugitive source is defined as an undesignated localized source, such as an open tank or naturally ventilated building.

Diffuse and fugitive releases are calculated using the U.S. Environmental Protection Agency's (EPA's) recommended methods [EPA, 2002]. Because these methods employ conservative assumptions, they generally lead to overestimates of actual emissions. Though these releases are not monitored at their source, onsite and offsite environmental monitoring stations are in place to quantify unexpectedly large diffuse and fugitive releases (chapter 5, "Environmental Surveillance").

\section{Monitoring Results Summary}

The total amount of radioactive material released to the environment is quantified by using (1) data obtained from continuously monitored airborne effluent release points and (2) estimates of diffuse and fugitive sources.

Tritium Tritium in elemental and oxide forms accounted for more than 99 percent of the total radioactivity released to the atmosphere from SRS operations. During 2008, about 34,600 Ci of tritium were released from SRS, compared to about 30,800 $\mathrm{Ci}$ in 2007. Most of the releases came from the site's tritium facilities.

During the past 10 years, because of changes in the site's missions and the beginning of operations at the Replacement Tritium Facility, the amount of tritium released from SRS has fluctuated but has remained less than 75,000 Ci per year (figure 4-1).

\section{Comparison of Average Concentrations in Air-} borne Emissions to DOE Derived Concentration Guides Average concentrations of radionuclides in airborne emissions are calculated by dividing the amount of each radionuclide released annually from each stack by the respective yearly stack-flow volumes. These average concentrations then can be compared to the DOE derived concentration guides (DCGs) in DOE Order 5400.5, "Radiation Protection of the Public and the Environment," as a screening method to determine if existing effluent treatment systems are proper and effective. The 2008 
atmospheric effluent annual-average concentrations, their comparisons against the DOE DCGs, and the quantities of radionuclides released are provided, by discharge point, on the $\mathrm{CD}$ accompanying this report.

DCGs are used as reference concentrations for conducting environmental protection programs at all DOE sites. DCGs are applicable at the point of discharge (prior to dilution or dispersion) under conditions of continuous exposure.

Most of the SRS radiological stacks/facilities release small quantities of radionuclides at concentrations below the DOE DCGs. However, tritium (in the oxide form) from the reactor (K-Area main stack, L-Area main stack, and L-Area disassembly basin) and tritium facilities was emitted in 2008 at concentration levels above the DCGs. The offsite dose from all atmospheric releases, however, remained well below the DOE and EPA annual atmospheric pathway dose standard of $10 \mathrm{mrem}(0.1 \mathrm{mSv})$, as discussed in chapter 6 .

\section{Liquid Discharges}

Each process area liquid effluent discharge point that releases, or has potential to release, radioactive materials is sampled routinely and analyzed for radioactivity [SRS EM Program, 2002].

Depending on the processes involved, liquid effluents also may be monitored with real-time instrumentation to ensure that releases are managed within established limits. Because the instruments have limited detection sensitivity, online monitoring systems are not used to quantify SRS liquid radioactive releases at their current low levels. Instead, samples are collected for more sensitive laboratory analysis.

\section{Monitoring Results Summary}

Data from continuously monitored liquid effluent discharge points are used in conjunction with site seepage basin and Solid Waste Disposal Facility (SWDF) migration release estimates to quantify the total radioactive material released to the Savannah River from SRS operations. SRS liquid radioactive releases for 2008 are shown by source on the CD accompanying this report. These data are a major component in the determination of offsite dose consequences from SRS operations.
Direct Discharges of Liquid Effluent Direct discharges of liquid effluents are quantified at the point of release to the receiving stream, prior to dilution by the stream. The release totals are based on measured concentrations and flow rates.

Tritium accounts for nearly all the radioactivity discharged in SRS liquid effluents. The total amount of tritium released directly from process areasi.e., reactor, separations, Effluent Treatment Facility (ETF) - to site streams during 2008 was 320Ci. Direct releases of tritium to site streams for the years 1999-2008 are shown in figure 4-2.

Operations at D-Area and TNX were discontinued in 2000 and 2001, respectively. A-Area releases represent only a small percentage of the total direct releases of tritium to site streams. The reactor area releases include the overflows from PAR Pond and L Lake.

Migration/transport of radionuclides from site seepage basins and SWDF are discussed in chapter 5 .

Comparison of Average Concentrations in Liquid
Releases to DOE Derived Concentration Guides addition to dose standards, DOE Order 5400.5 imposes other control considerations on liquid releases. These considerations are applicable to direct discharges but not to seepage basin and SWDF migration discharges. The DOE order lists DCG values for most radionuclides.

DCGs are applicable at the point of discharge from the effluent conduit to the environment (prior to dilution or dispersion). According to DOE Order 5400.5 , exceedance of the DCGs at any discharge point may require an investigation of "best available technology" (BAT) waste treatment for the liquid effluents. Tritium in liquid effluents is specifically excluded from BAT requirements; however, it is not excluded from other ALARA considerations. DOE DCG compliance is demonstrated when the sum of the fractional DCG values for all radionuclides detectable in the effluent is less than 1.00 , based on consecutive 12-month-average concentrations. The 2008 liquid effluent annual-average concentrations, their comparisons against the DOE DCGs, and the quantities of radionuclides released are providedby discharge point - on the $\mathrm{CD}$ accompanying this report.

The data show that ETF Outfall U3R-2A at the Road C discharge point exceeded the DCG guide 


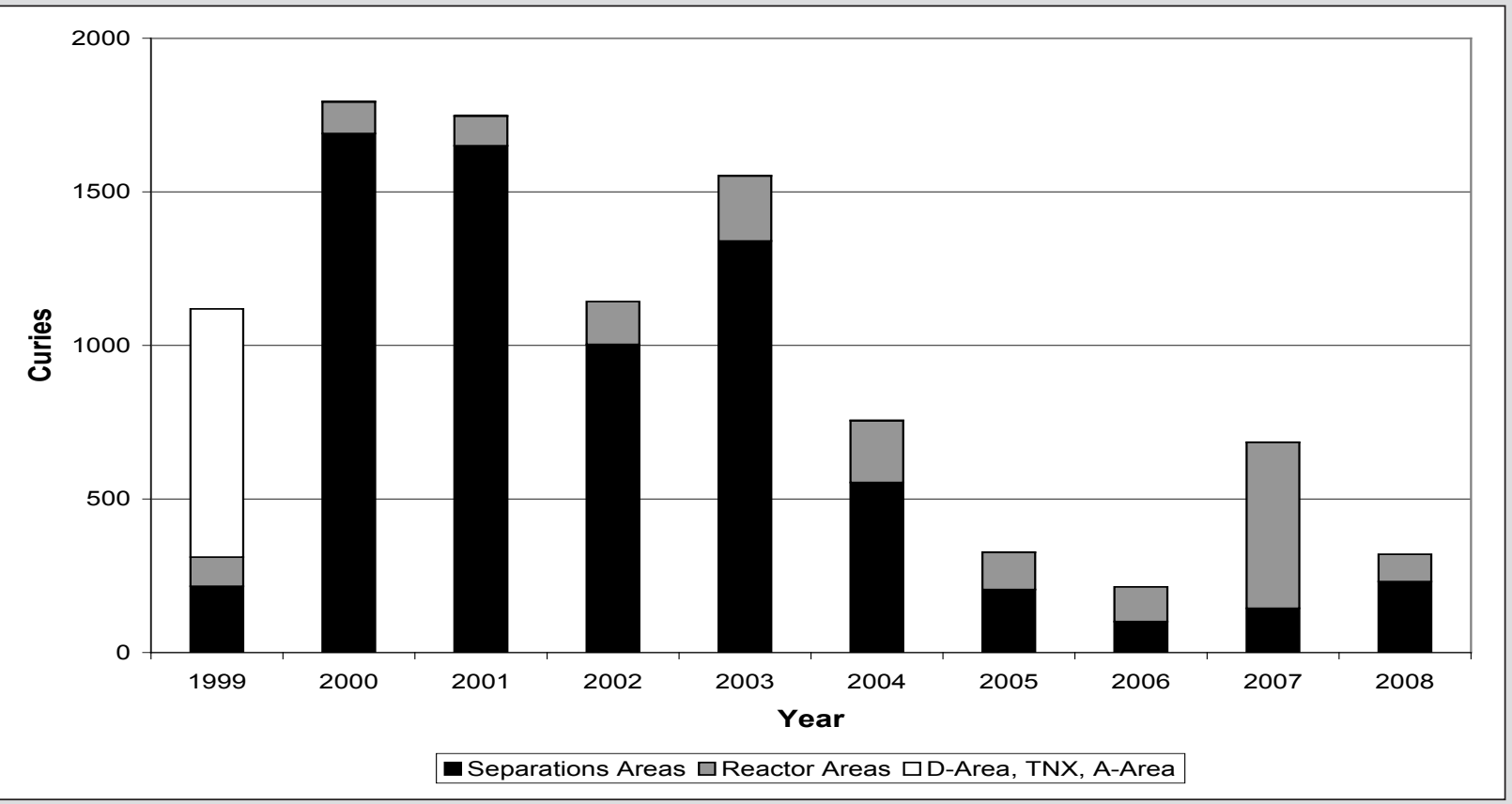

Figure 4-2 Ten-Year History of Direct Releases of Tritium to SRS Streams

for 12-month-average tritium concentrations again during 2008. However, as noted previously, DOE Order 5400.5 specifically exempts tritium from BAT waste treatment investigation requirements. This is because there is no practical technology available for removing tritium from dilute liquid waste streams.

In January 2008, H-Canyon released a small amount of alpha-contaminated water to the cooling water system in H-Area. The contaminated water was diverted and captured in the $281-8 \mathrm{H}$ retention basin, then transferred to the Effluent Treatment Project for treatment until the alpha level fell below the site's operational discharge limit of $3 \mathrm{dpm} / \mathrm{mL}$. At that point, the $281-8 \mathrm{H}$ water was released in batches to Fourmile Branch via the $\mathrm{H}-017$ outfall. However, because DCGs are very conservatively applied at the point of discharge, the 12-month average DCG for plutonium-238 was exceeded at $\mathrm{H}-017$ at the $3-\mathrm{dpm} /$ $\mathrm{mL}$ level. A BAT assessment was not deemed necessary for this exceedance because it was a known, episodic event that was handled using BAT (i.e., filtration through the Effluent Treatment Project). Although the DCG for plutonium-238 was exceeded at $\mathrm{H}-017$ as a result of this episodic release, the resulting potential increase in offsite dose was small and well below all applicable dose standards (see chapter 6, "Potential Radiation Doses").
No other liquid discharge points exceeded the DOE DCGs during 2008.

\section{Release of Material Containing}

\section{Residual Radioactivity}

DOE issued a moratorium in January 2000 prohibiting the release of volume-contaminated metals, and suspended the release of metals from DOE radiological areas in July 2000 for recycling purposes. No volume-contaminated metals or metals for recycling purposes were released from SRS in 2008.

DOE approved an SRS request in 2003 to use supplemental limits for releasing material from the site with no further DOE controls. These supplemental release limits are dose-based, and are such that if any member of the public received any exposure, it would be less than $1 \mathrm{mrem} / \mathrm{year}$. The supplemental limits include both surface and volume concentration criteria. The surface criteria are very similar to those used in previous years. The volume criteria allow the disposal of potentially volume-contaminated material in SRS's Three Rivers Landfill, an onsite sanitary facility. In 2008, no material was released from the site using the SRS Supplemental Release Limits volume concentration criteria. 
These measures ensure that radiological releases of material from SRS are consistent with the requirements of DOE Order 5400.5.

\section{Nonradiological Monitoring}

\section{Airborne Emissions}

The South Carolina Department of Health and Environmental Control (SCDHEC) regulates both radioactive and nonradioactive criteria and toxic air pollutant emissions from SRS sources. Each source of air emissions is permitted or exempted by SCDHEC on the SRS Part 70 Air Quality Permit (issued in 2003), with specific limitations and monitoring requirements identified. This section will cover only nonradioactive emissions.

The bases for the limitations and monitoring requirements specified in the Part 70 Air Quality Permit are outlined in various South Carolina and federal air pollution control regulations and standards. Many of the applicable standards are source dependent, i.e., applicable to certain types of industries, processes, or equipment. However, some standards govern all sources for criteria pollutants, toxic air pollutants, and ambient air quality. Air pollution control regulations and standards applicable to SRS sources are discussed briefly in appendix A, "Applicable Guidelines, Standards, and Regulations," of this report. The SCDHEC air standards for toxic air pollutants can be found at http://www.scdhec.gov/ environment/baq/docs/regs/.

\section{Description of Monitoring Program}

Major nonradiological emissions of concern from stacks at SRS facilities include sulfur dioxide, carbon monoxide, oxides of nitrogen, particulate matter smaller than (1) 10 micrometers and (2) 2.5 micrometers, volatile organic compounds (VOCs), and toxic air pollutants. With the issuance of the Part 70 Air Quality Permit, SRS has several continuous and periodic monitoring requirements; only the most significant are discussed below.

The primary method of source monitoring at SRS is the annual air emissions inventory. Actual emissions from SRS sources are determined during this inventory from standard calculations using source operating parameters, such as hours of operation, process throughput, and emission factors provided in the EPA "Compilation of Air Pollution Emission
Factors," AP-42. Many of the processes at SRS, however, are unique sources requiring nonstandard, complex calculations. The hourly and total actual annual emissions for each source then can be compared against their respective permit limitations.

At the SRS A-Area and D-Area Powerhouses, airborne emission specialists under contract to SRS perform stack compliance tests every two years. The tests include sampling of boiler exhaust gases to determine particulate matter, sulfur dioxide, and visible opacity emissions. The permit for the A-Area Powerhouse also requires a weekly sample and laboratory analysis of coal for sulfur content, and a daily visible-emissions inspection to verify compliance with opacity standards.

For the package steam generating boilers in K-Area, fuel oil-fired water heaters in B-Area, and dieselpowered equipment, compliance with sulfur dioxide standards is determined by analysis of the fuel oil purchased from the offsite vendor. Sulfur content of the fuel oil must be below 0.05 percent - and must be certified by the fuel supply vendor and reported to SCDHEC semiannually.

The monitoring of SRS diesel-powered equipment includes tracking fuel oil consumption monthly and calculating a 12-month rolling total for determining permit compliance with a site consumption limit.

SRS has several soil vapor extraction units and two air strippers that are sources of toxic air pollutants and VOCs. These units must be sampled monthly for VOC concentrations, and the total VOC emissions must be calculated for comparison against a 12 -month rolling limit. The VOC emissions then are reported to SCDHEC on a quarterly basis.

Several SRS sources have pollutant control devices-such as multiclone dust collectors, electrostatic precipitators, baghouse dust collectors, or condensers - whose parameters must be monitored continuously or whenever the system is operated. The operating parameters must be recorded and compared against specific operating ranges.

Compliance by all SRS permitted sources is evaluated during annual compliance inspections by the local SCDHEC district air manager. The inspections include a review of each permit condition; i.e., daily monitoring readings, equipment calibrations, control device inspections, etc. SCDHEC performed an air 
Table 4-1

SRS Estimated SCDHEC Standard 2 Pollutant Air Emissions, 2005-2007

Pollutant Name

Actual Emissions (Tons/Year)

Sulfur dioxide $\left(\mathrm{SO}_{\mathrm{x}}\right)$

Total particulate matter (PM)

Particulate matter $<10$ micrometers $\left(\mathrm{PM}_{10}\right)$

Particulate matter $<2.5$ micrometers $\left(\mathrm{PM}_{2.5}\right)$

Carbon monoxide (CO)

Ozone (volatile organic compounds)

Gaseous fluorides (as hydrogen fluoride) ${ }^{a}$

Nitrogen dioxide $\left(\mathrm{NO}_{x}\right)$

Lead (lead components)
$6.97 \mathrm{E}+03$
$9.28 \mathrm{E}+02$
$5.71 \mathrm{E}+02$
4.77E+02
1.03E+03
$5.48 \mathrm{E}+02$
1.43E-01
7.18E+03
1.74E-01

2006
2007

a The increase in gaseous flourides from 2005 to 2006 is attributed to updated and corrected D-Area Powerhouse (coal boilers) emission factors. In 2005 and previous years, gaseous fluoride emissions from the D-Area Powerhouse were not calculated. compliance inspection in August 2008 and found no instances of noncompliance.

\section{Monitoring Results Summary}

In 2008, operating data were compiled and emissions calculated for 2007 operations for all site air emission sources. Because this process, which begins in January, requires up to 6 months to complete, this report provides a comprehensive examination of total 2007 emissions, with only limited discussion of available 2008 monitoring results for specific sources.

The 2007 total SCDHEC Standard 2 emission estimates for all SRS permitted sources, as determined by the air emissions inventory conducted in 2008 , are provided in table 4-1. A review of the calculated emissions for each source for calendar year $2007 \mathrm{de}$ termined that SRS sources had operated in compliance with permitted emission rates. Some toxic air pollutants (e.g., benzene) regulated by SCDHEC also are, by nature, VOCs. As such, the total for VOCs in table 4-1 includes toxic air pollutant emissions.

Three power plants with nine overfeed stoker-fed coal-fired boilers are maintained by Savannah River Nuclear Solutions (SRNS) at SRS. The location, number of boilers, and capacity of each boiler for these plants are listed in table 4-2. A-Area Boiler No. 2 was stack-tested in February 2008. At that time, the boiler's sulfur dioxide and visible emissions were found to be in compliance with its permitted limit; however, the boiler's particulate matter emissions were found to be out of compliance with its permitted limit. The boiler was shut down permanently on March 19, 2008, and on September 13, 2008, A-Area Boiler No. 1 also was shut down permanently. Results from the A-Area Boiler No. 2 test are shown in table 4-3.

To replace the aging A-Area coal-fired boilers, SRS began construction of a biomass boiler and an oil-fired backup boiler in October 2007. Known 
Table 4-2

SRS Power Plant Boiler Capacities

\begin{tabular}{|c|c|c|}
\hline Location & $\begin{array}{l}\text { Number } \\
\text { of Boilers }\end{array}$ & $\begin{array}{l}\text { Capacity } \\
\text { (Btu/hr) }\end{array}$ \\
\hline A-Area & $2^{a}$ & 71.7E+06 \\
\hline A-Area & $2^{b}$ & $40.7 \mathrm{E}+06$ \\
\hline H-Area & $3^{c}$ & 71.1E+06 \\
\hline D-Area & 4 & $396.0 \mathrm{E}+06$ \\
\hline \multicolumn{3}{|c|}{ 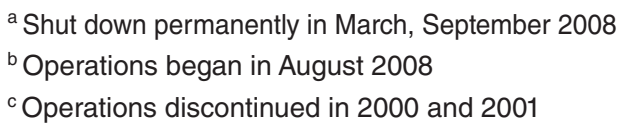 } \\
\hline
\end{tabular}

as the 784-7A Steam Facility, those two boilers are substantially smaller and burn cleaner than the two coal-fired boilers they replaced. The biomass boilers produce significantly less particulate matter, sulfur dioxide, and nitrogen dioxide emissions than the two coal-fired boilers. The biomass boiler and backup oil-fired boiler began operations in August 2008.

WSRC assumed operational responsibility for the D-Area Powerhouse (484-D) in February 2006 from South Carolina Electric and Gas (SCE\&G), which had operated the facility for DOE under a separate contract since 1995. The D-Area Powerhouse has four coal-fired boilers - each on a biennial stack test schedule required by the Part 70 Air Quality Permit. During 2008, only D-Area Powerhouse boilers D\#2 and D\#4 were scheduled to be tested. Boiler D\#4 could not be tested because of extended maintenance repairs; however the results for boiler $\mathrm{D} \# 2$ are shown in table 4-3. This boiler's particulate matter, sulfur dioxide, and visible emissions were found to be in compliance with its permitted limit.

The three H-Area Powerhouse boilers have not operated since 2000-2001.

SRS also has two package steam generating boilers in K-Area fired by No. 2 fuel oil. The percent of sulfur in the fuel oil must be vendor certified semiannually to ensure that the fuel meets permit specifications; the certification was documented twice during 2008.

The total diesel fuel consumption for portable air compressors, generators, emergency cooling water

Table 4-3

2008 Boiler Stack Test Results

\begin{tabular}{|c|c|c|c|}
\hline \multirow[b]{2}{*}{ Boiler } & \multirow[b]{2}{*}{ Pollutant } & \multicolumn{2}{|c|}{ Emission Rates } \\
\hline & & $\mathrm{lb} / 10^{6} \mathrm{Btu}$ & $\mathrm{lb} / \mathrm{hr}$ \\
\hline A-Area Boiler \#2 & $\begin{array}{l}\text { Particulates }^{a} \\
\text { Sulfur dioxide } \\
\text { Opacity }\end{array}$ & $\begin{array}{l}0.690 \\
1.318 \\
\text { Avg. } 12.5 \%\end{array}$ & $\begin{array}{l}31.45 \\
53.41\end{array}$ \\
\hline D-Area Boiler \#2 & $\begin{array}{l}\text { Particulates }^{\mathrm{a}} \\
\text { Sulfur dioxide }^{\mathrm{a}} \\
\text { Opacity }^{\mathrm{b}}\end{array}$ & $\begin{array}{l}0.088 \\
\mathrm{NC}^{\mathrm{d}} \\
\text { Avg. } 6.9 \%\end{array}$ & $\begin{array}{l}33.87 \\
N C^{d}\end{array}$ \\
\hline D-Area Boiler \#4 & $\begin{array}{l}\text { Particulates }^{\mathrm{a}} \\
\text { Sulfur dioxide }^{\mathrm{a}} \\
\text { Opacity }^{\mathrm{b}}\end{array}$ & & \\
\hline $\begin{array}{l}\text { a The compliance level is } 0.6 \mathrm{lb} \\
\text { b Opacity limit } 40 \% \\
{ }^{\mathrm{c}} \text { Not stack tested during } 2008 \\
{ }^{\mathrm{d}} \text { Not calculated }\end{array}$ & ticulates and $3.5 \mathrm{lb}$ & for sulfur dioxid & \\
\hline
\end{tabular}


pumps, and fire water pumps was found to be well below the SRS limit for the entire reporting period. As reported to SCDHEC during 2008, the calculated annual VOC emissions were well below the permit limit for each unit.

\section{Ambient Air Quality}

Under existing regulations, SRS is not required to conduct onsite monitoring for ambient air quality; however, the site is required to show compliance with various air quality standards. To accomplish this, air dispersion modeling is conducted as required as part of the Title $\mathrm{V}$ and construction permitting process. Additional information about ambient-air-quality regulations at the site can be found in appendix A of this report.

\section{Liquid Discharges}

\section{Description of Monitoring Program}

SRS monitors nonradioactive liquid discharges to surface waters through the National Pollutant Discharge Elimination System (NPDES), as mandated by the Clean Water Act. As required by EPA and SCDHEC, SRS has NPDES permits in place for discharges to the waters of the United States and South Carolina. These permits establish the specific sites to be monitored, parameters to be tested, and monitoring frequency - as well as analytical, reporting, and collection methods. Detailed requirements for each permitted discharge point can be found in the individual permits, which are available to the public through SCDHEC's Freedom of Information office at 803-898-3882.

In 2008, SRS discharged water into site streams and the Savannah River under three NPDES permits: two for industrial wastewater, SC0047431 (covers D-Area) and SC0000175 (covers remainder of site), and one for stormwater runoff-SCR000000 (industrial discharge). A fourth permit, SCR100000, does not require sampling unless requested by SCDHEC to address specific discharge issues at a given construction site; SCDHEC did not request such sampling in 2008.

SRS submitted a permit application in 2006 for each of nine individual stormwater outfalls for which the average of any four consecutive analyses exceeded the proposed EPA Multisector General Permit benchmarks. At the end of 2008, the site still had no response from SCDHEC regarding the individual permit applications.

Permit ND0072125 is a "no discharge" water pollution control land application permit that regulates sludge application and related sampling at onsite sanitary wastewater treatment facilities.

NPDES samples are collected in the field according to 40 CFR 136, the federal document that lists specific sample collection, preservation, and analytical methods acceptable for the type of pollutant to be analyzed. Chain-of-custody procedures are followed after collection and during transport to the analytical laboratory. The samples then are accepted by the laboratory and analyzed according to procedures listed in 40 CFR 136 for the parameters required by the permit.

\section{Monitoring Results Summary}

SRS reports industrial wastewater analytical results to SCDHEC through a monthly discharge monitoring report (EPA Form 3320-1). Results from only five of the 4,529 sample analyses (includes flow measurements and no-flow designations) performed during 2008 exceeded permit limits. This resulted in a 99.89-percent compliance rate for discharge monitoring results. Of the five exceptions, two warranted SCDHEC Notices of Violation, but no fines were assessed. Details related to the five exceptions appear in table 4-4. A complete presentation of the NPDES data, with the exceptions noted, can be found on the $\mathrm{CD}$ accompanying this report.

In 2008, 17 stormwater outfalls were scheduled for compliance sampling. All samples were obtained as scheduled, with the additional sampling of one outfall to determine the effectiveness of an installed best management practice (BMP). In addition to compliance sampling, special grab sampling was conducted at six outfalls to aid in evaluating compliance with the proposed general permit. It was reported in 2006 that 10 outfalls had exceeded EPA benchmarks and would require corrective actions. By the end of 2007, seven of these outfalls were in compliance. Installation of BMPs for the remaining three outfalls was completed in June 2008; evaluation of the effectiveness of these BMPs is ongoing. Complete stormwater data can be found on the CD accompanying this report. 
Table 4-4

2008 Exceptions to SCDHEC-Issued NPDES Permit Liquid Discharge Limits at SRS ${ }^{a}$

\begin{tabular}{|c|c|c|c|c|c|}
\hline Business Unit & Outfall & Date(s) & Parameter & $\begin{array}{l}\text { Possible } \\
\text { Cause(s) }\end{array}$ & $\begin{array}{l}\text { Corrective } \\
\text { Actions }\end{array}$ \\
\hline Site Infrastructure & $\mathrm{K}-12$ & March 11 & $\begin{array}{l}\text { Total Suspended } \\
\text { Solids (TSS) } \\
\text { (weekly avg) } \\
\text { Value: } 66 \text { mg/L } \\
\text { Limit: } 45 \text { mg/L }\end{array}$ & $\begin{array}{l}\text { Infiltration } \\
\text { of solids } \\
\text { from nearby } \\
\text { construction; } \\
\text { cement-like } \\
\text { material poured } \\
\text { in a collection } \\
\text { system; } \\
\text { inadequate } \\
\text { aeration }\end{array}$ & $\begin{array}{l}\text { Eliminated } \\
\text { infiltration, verified } \\
\text { contaminants not } \\
\text { present, replaced } \\
\text { air diffuser heads }\end{array}$ \\
\hline $\begin{array}{l}\text { Liquid Waste } \\
\text { Operations }\end{array}$ & $\mathrm{H}-16$ & May 12 & $\begin{array}{l}\text { TSS } \\
\text { (holding time) } \\
\text { Value: } 7.9 \text { days } \\
\text { Limit: } 7 \text { days }\end{array}$ & $\begin{array}{l}\text { Laboratory } \\
\text { exceeded } \\
\text { holding time } \\
\text { because } \\
\text { sample not } \\
\text { logged in upon } \\
\text { receipt at } \\
\text { laboratory }\end{array}$ & $\begin{array}{l}\text { Isolated incident, } \\
\text { but laboratory } \\
\text { took steps to } \\
\text { prevent repeat }\end{array}$ \\
\hline Site Infrastructure & $\mathrm{G}-10$ & July 16 & $\begin{array}{l}\text { Fecal Coliform } \\
\text { (daily max) } \\
\text { Value: } 746 \mathrm{col} / 100 \mathrm{~mL} \\
\text { Limit: } 400 \mathrm{col} / 100 \mathrm{~mL}\end{array}$ & $\begin{array}{l}\text { Cause not } \\
\text { identified } \\
\text { after thorough } \\
\text { investigation; } \\
\text { appears to be } \\
\text { anomaly }\end{array}$ & $\begin{array}{l}\text { Pursue onsite } \\
\text { certification for } \\
\text { fecal coliform } \\
\text { analyses to } \\
\text { reduce potential } \\
\text { for contamination } \\
\text { or growth during } \\
\text { sample transport } \\
\text { to offsite } \\
\text { laboratory }\end{array}$ \\
\hline $\begin{array}{l}\text { Materials } \\
\text { Disposition }\end{array}$ & $\mathrm{H}-12$ & August 7 & $\begin{array}{l}\begin{array}{l}\text { Copper } \\
\text { (daily max) }\end{array} \\
\text { Value: } 39.9 \text { mg/L } \\
\text { Limit: } 35 \text { mg/L }\end{array}$ & $\begin{array}{l}\text { Solids in the } \\
\text { sample }\end{array}$ & $\begin{array}{l}\text { Unable to } \\
\text { determine } \\
\text { specific cause; } \\
\text { comprehensive } \\
\text { sampling plan } \\
\text { implemented }\end{array}$ \\
\hline $\begin{array}{l}\text { Defense } \\
\text { Programs }\end{array}$ & $\mathrm{H}-02$ & November 11 & $\begin{array}{l}\begin{array}{l}\text { Copper } \\
\text { (monthly avg) }\end{array} \\
\text { Value: } 0.0073 \mathrm{mg} / \mathrm{L} \\
\text { Limit: } 0.007 \mathrm{mg} / \mathrm{L}\end{array}$ & $\begin{array}{l}\text { Until November } \\
1 \text {, copper limit } \\
\text { was monitor } \\
\text { and report } \\
\text { (no limit); on } \\
\text { November } 1 \text {, } \\
\text { limit of } 0.007 \\
\text { mg/l imposed } \\
\text { by SCDHEC }\end{array}$ & $\begin{array}{l}\text { Permit } \\
\text { modification } \\
\text { issued by } \\
\text { SCDHEC; } \\
\text { effective } \\
\text { November } 30 \text {, } \\
\text { monthly average } \\
\text { limit raised to } \\
0.032 \mathrm{mg} / \mathrm{l}\end{array}$ \\
\hline
\end{tabular}



Environmental Surveillance

Donald Padgett, Monte Steedley, Pete Fledderman, and Teresa Eddy

Regulatory Integration \& Environmental Services

Timothy Jannik

Savannah River National Laboratory

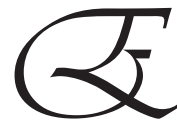

nvironmental surveillance at the Savannah River Site (SRS) is designed to survey and quantify any

effects that routine and nonroutine operations could have on the site and on the surrounding area and population. Site surveillance activities are divided into radiological and nonradiological programs.

As part of SRS's radiological surveillance program, routine surveillance of all radiation exposure pathways is performed on all environmental media (air, rain, ambient gamma radiation, surface water, soil, sediment, vegetation, drinking water, food products, and wildlife) that could lead to a measurable annual dose above background at and beyond the site boundary.

Nonradioactive environmental surveillance at SRS involves the sampling and analysis of surface water, drinking water, sediment, groundwater, and fish. Results from the analyses of surface water, drinking water, sediment, and fish are discussed in this chapter. A description of the groundwater monitoring program analysis results can be found in chapter 7, "Groundwater."

The Regulatory Integration \& Environmental Services Department's Environmental Monitoring (EM) section performs surveillance activities for SRS. The Savannah River also is monitored by other groups, including the South Carolina Department of Health and Environmental Control (SCDHEC), the Georgia Department of Natural Resources, Georgia Power Company's Vogtle Electric Generating Plant (operating in Georgia), and the City of Savannah, Georgia.

A complete description of the EM surveillance program, including sample collection and analytical procedures, can be found in section 1105 of the Savannah River Site Environmental Monitoring Program, WSRC-3Q1-2, Volume 1, Revision 4 (SRS EM Program, 2002). Brief summaries of analytical results are presented in this chapter; complete data sets can be found in tables on the $\mathrm{CD}$ accompanying this report.

\section{Radiological Surveillance}

\section{Air \\ Description of Surveillance Program}

EM maintains a network of 15 sampling stations in and around SRS to monitor the concentration of tritium and radioactive particulate matter in the air.

\section{Surveillance Results Summary}

Except for tritium, monitored radionuclides were not routinely detectable at the site perimeter. Both onsite and offsite radioactivity concentrations were similar to levels observed in previous years (see expanded discussion in paragraphs that follow).

Average gross alpha and gross beta results were slightly lower in 2008 than in 2007, and are consistent with historical results in demonstrating longterm variability.

No 2008 samples contained the detectable manmade gamma-emitting radionuclide cesium-137. Historically, only a small number of air samples have contained detectable cesium-137 activity.

During 2008, detectable levels of uranium-234 were observed in three air samples; however no detectable levels of uranium-238 were observed in any of 
the 2008 samples. These results are similar to those observed in 2007. Uranium is naturally occurring in soil, and therefore expected to be present in low concentrations on some particulate filters. Aside from uranium, alpha-emitting radionuclide activity was observed in two samples from two locations-site perimeter and 25-mile. The site perimeter location revealed corresponding increases in plutonium-238, plutonium-239, and americium-241 for the same sampling date, which is consistent with the true presence of plutonium. Generally, these concentrations were consistent with historical results. For the remaining locations, all alpha-emitting isotopes were below detection levels. All 2008 strontium-89,90 results were below the minimum detectable concentration (MDC), whereas, two of the 2007 sample results were above the MDC. The dose consequences are explained in more detail in chapter 6 ("Potential Radiation Doses").

Tritium-in-air results for 2008 were similar to-but generally higher than - those observed in 2007. However, the results are consistent with the longterm variability of historical results. The Burial Ground North (BGN) tritium-in-air results were slightly lower than those observed in 2007. As in previous years, the BGN location showed average and maximum concentrations significantly higher than those observed at other locations. BGN results are expected to be both higher and more variable because of the location's proximity to both the tritium facilities and the phytoremediation project near the center of the site, and are influenced by operations at these facilities. Tritium was detected at every sampling location, although not every sample from a particular location had detectable tritium. As expected, tritium concentrations generally decreased with increasing distance from the tritium facilities.

\section{Rainwater}

\section{Description of Surveillance Program}

SRS maintains a network of 15 rainwater sampling sites as part of the air surveillance program. These stations are used to measure deposition of radioactive materials.

\section{Surveillance Results Summary}

No detectable manmade gamma-emitting radionuclides were observed in rainwater samples in 2008.
Gross alpha and gross beta results from 2008 were consistent with those of 2007. In 2008, the average gross alpha results generally were slightly lower (four of seven locations showed a decrease) than those of 2007, while average gross beta results were slightly higher (four of seven locations showed an increase). Annual average gross alpha and gross beta concentrations, as well as individual sample results, are consistent with historical results, which demonstrate long-term variability.

Detectable levels of uranium-234 and uranium-238 were present in most samples. Uranium is naturally occurring in soil, and therefore expected to be present at low concentrations in some deposition samples. Elevated uranium-238 results again were observed at the D-Area and BGN locations. Increased airborne particulate matter (dust) is present at these locations as a result of one or both of the following: (1) D\&D activities in the immediate vicinity, resulting in the movement of large amounts of soil, and (2) increased vehicle traffic on nearby dirt roads or fields. It is believed that this phenomenon is responsible for the observed increase. All locations showed detectable americium-241 (overall, 18 percent of the samples), with an average concentration of $1.60 \mathrm{E}-01 \mathrm{pCi} / \mathrm{L}$ - well below the drinking water standard. All other actinides, as well as strontium-89,90, either were below detection levels or were present in only a small number of samples in 2008 .

As in previous years, tritium-in-rain values were highest near the center of the site-except for one value at the Augusta Lock and Dam that is considered an outlier. The tritium-in-rain result for August 2008 at the Augusta Lock and Dam is believed to be an outlier due to a lab error because (1) it is much higher than historical levels, (2) it is the only result for this location above the minimum detectable concentration for the entire year, (3) it is higher than locations located closer to the center of the site, and (4) the cycles immediately before and after the result in question were consistent with long-term levels. All samples from the center of the site contained detectable tritium. This is consistent with the H-Area effluent release points that routinely release tritium. Beyond the center of the site, tritium was detected in only seven samples representing six locations on the site perimeter. As with tritium in air, concentrations generally decreased as distance from the effluent release point increased. 


\section{Gamma Radiation}

\section{Description of Surveillance Program}

Ambient dose rates from gamma radiation exposures in and around SRS are monitored by a system of thermoluminescent dosimeters (TLDs).

\section{Surveillance Results Summary}

Ambient dose rates at all TLD monitoring locations show some variation based on normal site-to-site and year-to-year differences in the components of natural ambient gamma radiation exposure levels. In 2008, ambient dose rates varied between 67 and 115 mrem per year.

In general, the 2008 ambient gamma radiation monitoring results indicated gamma radiation dose rates slightly higher than those observed at the same locations in 2007. However, due to equipment malfunction, only partial results were available for the fourth quarter of 2008. In addition, results for the control samples from the third quarter were inadequate because of no exposure prior to field use; therefore, all sample results for this quarter were omitted. The averages were based only on the correct data results that were available. The average annual dose rate was $87 \mathrm{mrem}$ in 2008, compared to $76 \mathrm{mrem}$ in 2007; all locations showed higher average annual dose rates in 2008. However, these results generally are consistent with previously published historical results, and indicate that no significant difference in average annual dose rates is observed between monitoring networks - except in the case of population centers. Ambient dose rates in population centers are slightly elevated compared to the other monitoring networks - as expected - because of factors such as buildings and roadways, which emit small amounts of radiation.

\section{Stormwater Basins}

\section{Description of Surveillance Program}

Stormwater accumulating in site stormwater basins is monitored because of potential contamination. In 2008, monitoring was conducted at six E-Area basins, as well as at the Z-Area Basin and F-Area Pond 400.

\section{Surveillance Results Summary}

There are no active discharges to site stormwater basins. The primary contributor is rainwater runoff. Rain events did not supply enough water to the E-06 basin for sampling purposes in 2008. The highest stormwater basin mean tritium concentration was measured in the E-05 basin, and was consistent with historical results - although slightly higher than the highest stormwater basin concentration in 2007. Fission products were observed in the basins, with no iodine-129 in any basin and with cesium137 appearing only in the Z-A Basin. Uranium-234, uranium-238, and plutonium-238 were the primary actinides detected in the basins. Gross alpha and gross beta were detected at all basins in concentrations generally consistent with those of previous years.

\section{Streams}

\section{Description of Surveillance Program}

Continuous surveillance monitoring of SRS streams is utilized downstream of several process areas to detect and quantify levels of radioactivity in effluents transported to the Savannah River. The five primary streams are Upper Three Runs, Fourmile Branch, Pen Branch, Steel Creek, and Lower Three Runs. The frequency and types of analyses performed on each sample are based on potential quantity and types of radionuclides likely to be present at the sampling location.

\section{Surveillance Results Summary}

Detectable concentrations of tritium, the predominant radionuclide detected above background levels in SRS streams, were observed at least once at all stream locations in 2008. Tritium releases to site streams increased slightly during 2008 over 2007primarily in direct releases to Upper Three Runs and in migration to Fourmile Branch. However, concentrations remain consistent with long-term tritium levels.

No detectable concentrations of cobalt-60 were observed in any of the five major SRS streams. Cesium137 was detected in these streams, but none was detected at the final discharge measurement points 


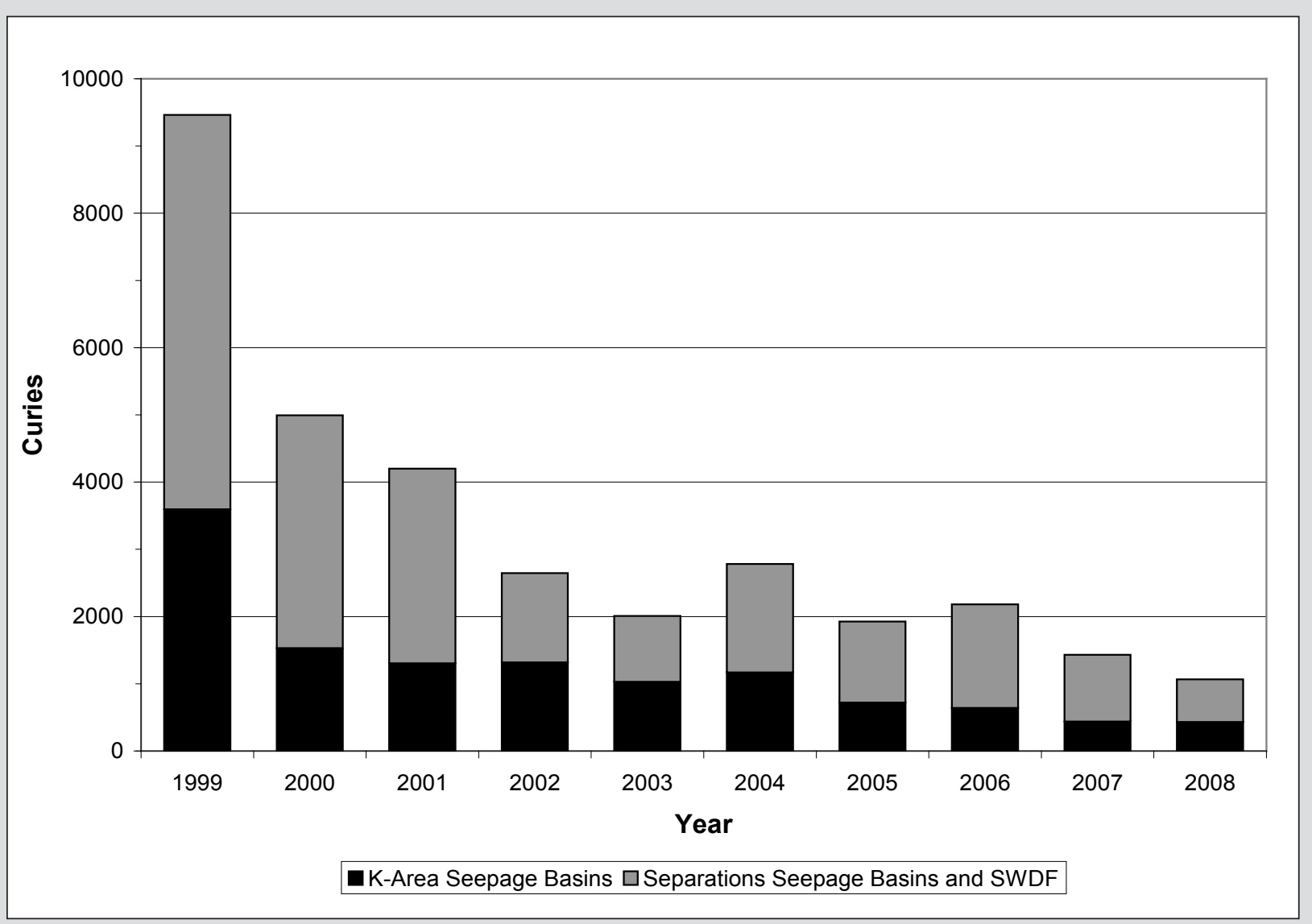

Figure 5-1 Tritium from SRS Seepage Basins and SWDF to Site Streams, 1999-2008

of the streams. As expected, gross alpha and gross beta were detected in all streams but concentrations were consistent with levels of recent years. Otherradionuclides were observed at locations throughout the site, but were consistent with the source of the material, and exhibited variations similar to those of previous years. No significant trends were observed in 2008 when compared to recent years.

\section{Seepage Basin and Solid Waste Disposal Facility Radionuclide Migration}

To incorporate the migration of radioactivity to site streams into total radioactive release quantities, EM personnel continued to monitor and quantify the migration of radioactivity from site seepage basins and the Solid Waste Disposal Facility (SWDF) in 2008 as part of its stream surveillance program. Tritium, strontium-89,90, technetium-99, iodine-129 and cesium-137 were detected in migration releases.
Figure $5-1$ is a graphical representation of releases of tritium via migration to site streams for the years 1999-2008. As can be seen in the figure, migration releases of tritium generally have declined the past 10 years, with year-to-year variability caused mainly by the amount of annual rainfall. During 2008, the total quantity of tritium migrating from site seepage basins and SWDF was 1,215 Ci.

Radioactivity previously deposited in the F-Area and H-Area seepage basins and SWDF continues to migrate through the groundwater and to outcrop into Fourmile Branch and Upper Three Runs. Because of their proximity, migration from the SWDF cannot be distinguished from migration from a part of H-Area Basin 4. Measured migration of tritium into Fourmile Branch in 2008 occurred as follows:

- from F-Area seepage basins, $71 \mathrm{Ci}-\mathrm{a} 54-$ 
percent decrease from the 2007 total of $154 \mathrm{Ci}$

- from SDWF and a part of H-Area seepage basin 4, $493 \mathrm{Ci}-\mathrm{a}$ 48-percent increase from the 2007 total of $333 \mathrm{Ci}$

- from H-Area seepage basins 1, 2, 3, and most of 4, $131 \mathrm{Ci}-\mathrm{a} 39$-percent increase from the 2007 total of $94 \mathrm{Ci}$

The measured migration from the north side of SWDF and the General Separations Area (GSA) into Upper Three Runs in 2008 was 20 Ci, a 63-percent decrease from the 2007 total of $54 \mathrm{Ci}$. (The GSA is in the central part of SRS and contains all waste disposal facilities, chemical separations facilities, and associated high-level waste storage facilities, along with numerous other sources of radioactive material.)

The total amount of strontium-89,90 entering Fourmile Branch from the GSA seepage basins and SWDF during 2008 was estimated to be $25.4 \mathrm{mCi}$. Migration releases of strontium-89,90 vary from year to year but have remained below $100 \mathrm{mCi}$ the past 7 years.

In 2008, $9.7 \mathrm{mCi}$ of technetium-99, $19.9 \mathrm{mCi}$ of iodine-129, and $153 \mathrm{mCi}$ of cesium-137 were estimated to have migrated into Fourmile Branch.

K-Area Drain Field and Seepage Basin Liquid purges from the K-Area disassembly basin were released to the K-Area seepage basin in 1959 and 1960. From 1960 until 1992, purges from the K-Area disassembly basin were discharged to a percolation field below the K-Area retention basin. Tritium migration from the seepage basin and the percolation field is measured annually in Pen Branch. The 2008 migration total of $500 \mathrm{Ci}$ represents a slight increase from the $431 \mathrm{Ci}$ recorded in 2007.

C-Area, L-Area, and P-Area Seepage Basins Liquid purges from the C-Area, L-Area, and P-Area disassembly basins were released periodically to their respective seepage basins from the 1950s until 1970. Migration releases from these basins are accounted for in the stream transport totals (see "Tritium Transport in Streams" section of this chapter).

\section{Transport of Actinides in Streams}

Transport (flux) in site streams of the actinides uranium, plutonium, americium, and curium no longer is quantified because of the actinides' historically low levels. However, the streams are sampled and analyzed annually for the presence of these actinides. The resulting concentrations are compared to those of previous years to identify any trends. Values for 2008 were consistent with historical data.

\section{Savannah River}

\section{Description of Surveillance Program}

Continuous surveillance is performed along the Savannah River at locations above and below SRS, including a location at which liquid discharges from Georgia Power Company's Vogtle Electric Generating Plant (VEGP) enter the river.

\section{Surveillance Results Summary}

Based on curies released, tritium is the predominant radionuclide detected above background levels in the Savannah River. The combined SRS and VEGP tritium releases (weekly composites) at River Mile (RM) 118.8 increased in 2008, but levels were well below the drinking water standard. Except for cesium-137 recorded at one location during a one-week period, no gamma emitters were detected. Detectable gross alpha and gross beta activity was observed at all river sampling locations, and was consistent with long-term gross alpha and gross beta levels in the river.

In addition to the weekly composite samples referred to above, SRS collects annual grab samples to provide a more comprehensive suite of radionuclides. Uranium-234 and uranium-238 were quantified in all these grab samples in 2008. Annual sampling also detected the manmade radionuclides americium-241 and technetium-99. Americium-241 has been detected previously in the river, but technetium-99 has not.

\section{Tritium Transport in Streams}

Tritium is introduced into SRS streams and the Savannah River from former production areas on site. Because of the mobility of tritium in water and the quantities of the radionuclide released during the years of SRS operations, a tritium balance has been performed annually since 1960 . The balance is evaluated among the following alternative methods of calculation: 


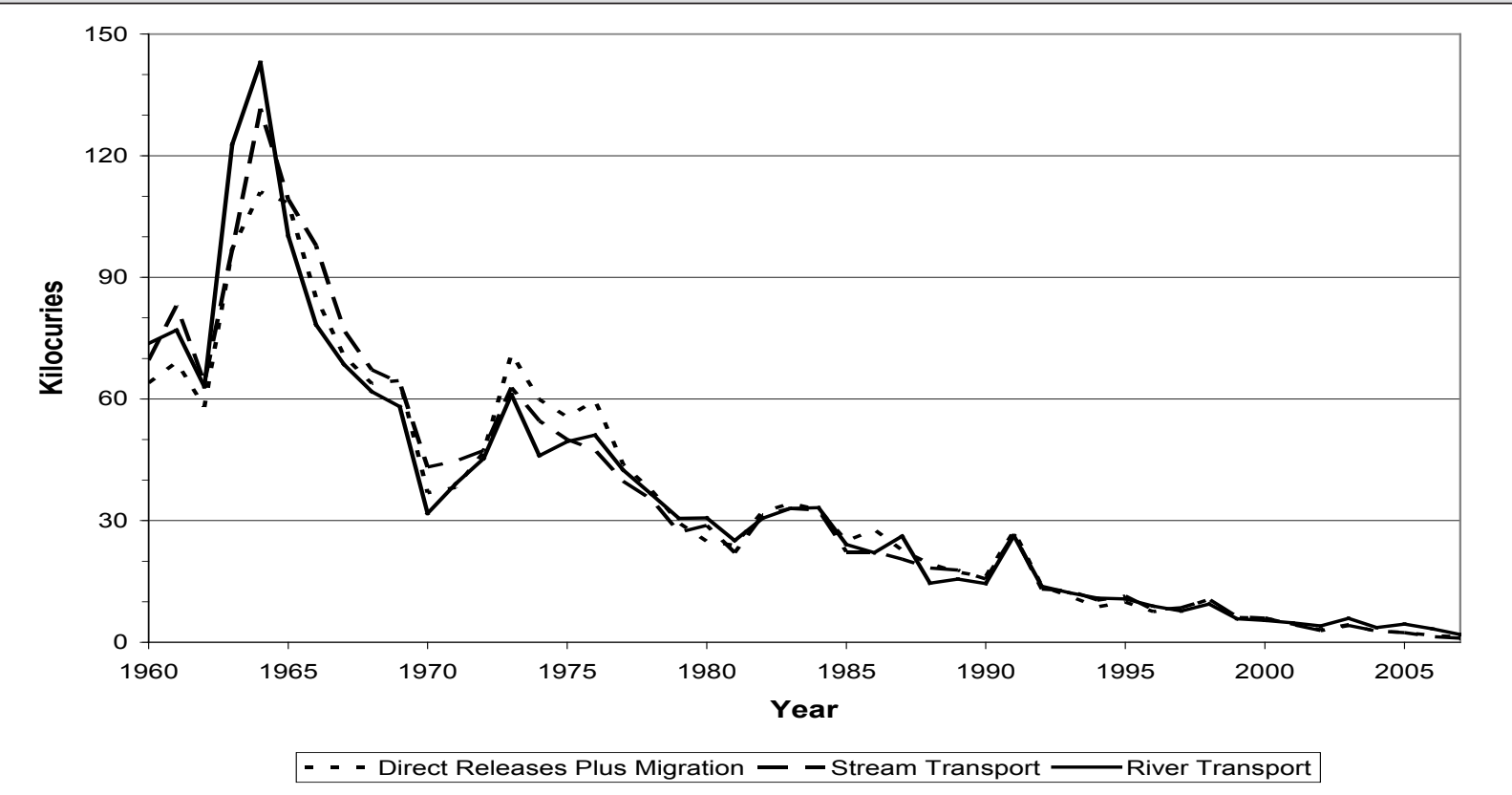

Figure 5-2 SRS Tritium Transport Summary, 1960-2008

SRS has maintained a tritium balance of direct releases plus migration, stream transport, and river transport since 1960 in an effort to account for and trend tritium releases in liquid effluents from the site. The general trend over time is attributable to (1) variations in tritium production at the site (production discontinued in the late 1980s); (2) the implementation of effluent controls, such as seepage basins, beginning in the early 1960s; and (3) the continuing depletion and decay of the site's tritium inventory.

- $\quad$ tritium releases from effluent release points and calculated seepage basin and SWDF migration (direct releases)

- tritium transport in SRS streams and the last sampling point before entry into the Savannah River (stream transport)

- tritium transport in the Savannah River downriver of SRS after subtraction of any measured contribution above the site (river transport)

Combined tritium releases in 2008 (direct discharges and migration from seepage basins and SWDF) totaled 1,535 Ci, compared to 1,317 Ci in 2007.

The total tritium transported to the Savannah River from SRS streams increased from $1,025 \mathrm{Ci}$ in 2007 to 1,185 Ci in 2008.

The total tritium released to the Savannah River in 2008 was 2,659 Ci, compared with the previous year's 1,938 Ci. Both VEGP and SRS contributed to these release values. SRS's calculated releases of tritium to the river in 2008 totaled $1,364 \mathrm{Ci}$.
SRS tritium transport data for 1960-2008 are depicted in figure 5-2, which shows the history of direct releases, stream transport, and river transport, as determined by EM.

EM personnel continued to assess the tritium flux in the Lower Three Runs system in 2008. A more extensive tritium flux assessment initially was conducted in 2004-and described in the SRS Environmental Report for 2004. As it has during the past several years, a small but measurable amount of tritium from earlier EnergySolutions LLC (formerly ChemNuclear Systems) low-level radioactive waste disposal facility operations entered the stream system in 2008. The facility is privately owned and located adjacent to SRS. The amount of tritium entering the system is expected to continue a gradual decline over time. EnergySolutions LLC began a program of capping the tritium sources in 1991, thereby reducing the amount of tritium entering the groundwater. The tritium currently in groundwater will continue to decay and dilute as it moves from the source toward Lower Three Runs. EM and EnergySolutions will maintain a monitoring program for Lower Three Runs to evaluate this tritium migration. 


\section{Domestic Water}

\section{Description of Surveillance Program}

EM collected domestic water samples in 2008 from locations at SRS and at water treatment facilities that use Savannah River water. Potable water was analyzed at offsite treatment facilities to ensure that SRS operations did not adversely affect the water supply and to provide voluntary assurance that drinking water did not exceed EPA drinking water standards for radionuclides.

Onsite domestic water sampling consisted of quarterly grab samples at large treatment plants in A-Area, D-Area, and K-Area and annual grab samples at wells and small systems. Composite samples were collected monthly off site from

- the Beaufort-Jasper Water and Sewer Authority's Chelsea and Purrysburg Water Treatment Plants

- the City of Savannah Industrial and Domestic Water Supply Plant

- the North Augusta (South Carolina) Water Treatment Plant

\section{Surveillance Results Summary}

All domestic water samples collected by EM in 2008 were screened for gross alpha and gross beta concentrations to determine if activity levels warrant further analysis. No domestic water exceeded EPA's 15-pCi/L alpha activity limit or 50-pCi/L beta activity limit. Also, no onsite or offsite domestic water samples exceeded the 20,000-pCi/L EPA tritium limit or the 8-pCi/L strontium-89,90 MDC.

No cobalt-60, cesium-137, uranium-235, plutonium-239, or curium-244 was detected in any domestic water samples in 2008. On site, americium-241 was detected at four locations, uranium-234 at five locations, uranium-235 at one location, and uranium -238 at six locations.

\section{Terrestrial Food Products}

\section{Description of Surveillance Program}

The terrestrial food products surveillance program consists of radiological analyses of food product samples typically found in the Central Savannah
River Area (CSRA). These foods include milk, meat (beef), fruit, and green vegetables (collards). Data from the food product surveillance program are not used to show direct compliance with any dose standard; however, the data can be used as required to validate dose models and determine environmental trends.

Samples of food-including meat (beef), fruit (melons or peaches), and a green vegetable (collards) - are collected from one location within each of four SRS quadrants and from a control location within an extended (to 25 miles beyond the perimeter) southeast quadrant. All food samples are collected annually except milk, which is collected quarterly from seven dairies within a 25 -mile radius of the site. Four of the seven dairies were open during only two quarters in 2008. The food product surveillance program was expanded in 2005 to include secondary crops on a rotating schedule. Pecans and peanuts were sampled in 2008 as part of this program.

Food samples typically are analyzed for the presence of gamma-emitting radionuclides, tritium, strontium-89,90, uranium-234, uranium-235, uranium238, plutonium-238, plutonium-239, americium-241, curium-244, gross alpha, and gross beta.

\section{Surveillance Results Summary}

The only gamma-emitting radionuclide detected in food products in 2008 was cesium-137, which was found in collards at two locations and pecans and peanuts at one location. Strontium-89,90 was detected in collards at all locations and in beef at one location. Uranium-234 was detected in three collard and three beef samples, while uranium-238 was detected in four beef samples and two collard samples. Plutonium-238 was detected in four beef samples. Americium-241 was detected in one collard, one peanut, and two pecan samples. Gross beta was detected in all food products and gross alpha was detected in one collard sample. The 2008 results appeared to be randomly distributed among the monitoring locations, and no underlying spatial distribution was observed.

Tritium in food products is attributed primarily to releases from SRS; however, tritium was detected only in beef (northeast quadrant, 1.14E-01 pCi/g) and in milk (Girard, 6.00E $+02 \mathrm{pCi} / \mathrm{L}$ ). These results are similar to those of previous years. 


\section{Aquatic Food Products}

\section{Description of Surveillance Program}

The aquatic food product surveillance program includes fish (freshwater and saltwater) and shellfish. To determine the potential dose and risk to the public from consumption, both types are sampled.

Nine surveillance points for the collection of freshwater fish are located on the Savannah River-from above SRS at Augusta, Georgia, to the coast at Savannah, Georgia. Composite samples-comprised of three to five fish of a given species - are prepared for each species from each location. Analyses for technetium-99; iodine-129; and the actinide series (uranium-234, uranium-235, and uranium-238, plutonium-238 and plutonium-239, americium-241, and curium-244) were added to all samples in 2006.

\section{Surveillance Results Summary}

Cesium-137 and iodine-129 were the only manmade gamma-emitting radionuclides found in Savannah River edible fish composites during 2008. Strontium-89,90, uranium-234, uranium-238, plutonium-238, and tritium were detected at most of the river locations for freshwater fish. Concentrations were similar to those of previous years. Neptunium-237 was found slightly above the MDC in one composite sample of catfish from Beaver Dam Creek Mouth and one composite from the Highway 301 Bridge vicinity.

Tritium, uranium-234, uranium-235, uranium-238, plutonium-238 and strontium-89,90 were detected in saltwater fish; americium-241, uranium-234, uranium-235, uranium-238, and strontium 89,90 were detected in shellfish. Concentrations were similar to those of previous years.

\section{Deer and Hogs}

\section{Description of Surveillance Program}

Annual hunts, open to members of the general public, are conducted at SRS to control the site's deer and feral hog populations and to reduce animalvehicle accidents. Before any animal is released to a hunter, EM personnel use portable sodium iodide detectors to perform field analyses for cesium-137. Media samples (muscle and/or bone) are collected periodically for laboratory analysis based on a set frequency, on cesium-137 levels, and/or on exposure limit considerations. SRS established an administrative dose limit of $30 \mathrm{mrem}$ per year for the consumption of game animals in 2006. This limit, which ensures that no single pathway contributes more than 30 percent to the all-pathway dose limit of 100 mrem, is consistent with DOE guidance. The doses from deer and hog consumption are quantified and reported in chapter 6 .

\section{Surveillance Results Summary}

A total of 432 deer and 110 feral hogs were taken during the 2008 site hunts. As observed during previous hunts, cesium-137 was the only manmade gamma-emitting radionuclide detected during laboratory analysis. Generally, the cesium- 137 concentrations measured by the field and lab methods were comparable. Field measurements from all animals ranged from $1 \mathrm{pCi} / \mathrm{g}$ to $12.65 \mathrm{pCi} / \mathrm{g}$, while lab measurements ranged from $1 \mathrm{pCi} / \mathrm{g}$ to $8.53 \mathrm{pCi} / \mathrm{g}$. The average field cesium-137 concentration was $2.40 \mathrm{pCi} / \mathrm{g}$ in deer (with a maximum of $12.65 \mathrm{pCi} / \mathrm{g}$ ) and $2.91 \mathrm{pCi} / \mathrm{g}$ in hogs (with a maximum of $8.53 \mathrm{pCi} / \mathrm{g}$ ). This range of concentrations is normal for the site's deer and hog populations.

The muscle and bone samples from a subset of the animals returned to the lab for cesium-137 analysis also are analyzed for strontium-89,90. Typically, muscle and bone samples are collected for analysis from the same animals checked for cesium-137, and the samples are analyzed for strontium-89,90. Strontium was detected in muscle tissue in 2008, with highs of $4.35 \mathrm{pCi} / \mathrm{g}$ in deer and $0.016 \mathrm{pCi} / \mathrm{g}$ in hogs. Lab measurements of strontium-89,90 in bone ranged from a high of $16.70 \mathrm{pCi} / \mathrm{g}$ to below detection in deer and from a high of $5.97 \mathrm{pCi} / \mathrm{g}$ to below detection in hogs. These results are similar to those of previous years.

\section{Turkeys/Beavers}

\section{Description of Surveillance Programs}

Prior to 2003, wild turkeys were trapped on site by the South Carolina Department of Natural Resources and used to repopulate game areas in South Carolina and other states. Since that time, the program has remained inactive because of reduced needs. 
During April 2008, a special hunt for the mobility impaired was held that resulted in the harvest of 17 turkeys. The average cesium-137 concentration measured in the field was $1.30 \mathrm{pCi} / \mathrm{g}$.

The U.S. Department of Agriculture Forest ServiceSavannah River harvests beavers in selected areas within the SRS perimeter to reduce the population and thereby minimize dam-building activities that can result in flood damage to timber stands, to primary and secondary roads, and to railroad beds. This activity resumed during 2006. Although population control activities continued in 2008 , no beavers were removed from their habitat for disposal.

\section{Soil}

\section{Description of Surveillance Program}

The SRS soil monitoring program provides

- data for long-term trending of radioactivity deposited from the atmosphere (both wet and dry deposition)

- information on the concentrations of radioactive materials in the environment

The concentrations of radionuclides in soil vary greatly among locations because of differences in rainfall patterns and in the mechanics of retention and transport in different types of soils. Two locations (West Jackson and Windsor Road) were added to the program in 2007. Because of this program's design, a direct comparison of data from year to year is not appropriate. However, the data may be evaluated over a period of years to determine long-term trends.

\section{Surveillance Results Summary}

In 2008, radionuclides were detected in soil samples from all 23 locations, as follows:

- cesium-137 at 17 locations (three onsite, all 12 perimeter, and two offsite)

- uranium-234 at all locations

- uranium-235 at all locations
- uranium-238 at all locations

- plutonium-238 at nine locations (four onsite, three perimeter, and two offsite)

- $\quad$ plutonium-239 at 13 locations (three onsite, eight perimeter, and two offsite)

- americium-241 at nine locations (three onsite, three perimeter, and three offsite)

- curium-244 at three locations (two onsite and one perimeter)

The concentrations at these locations are consistent with historical results. Uranium is naturally occurring in soil and therefore expected to be present in soil samples.

\section{Settleable Solids}

\section{Description of Surveillance Program}

Settleable-solids monitoring in effluent water is required to determine-in conjunction with routine sediment monitoring - whether a long-term buildup of radioactive materials occurs in stream systems.

DOE limits on radioactivity levels in settleable solids are $5 \mathrm{pCi} / \mathrm{g}$ above background for alpha-emitting radionuclides and $50 \mathrm{pCi} / \mathrm{g}$ above background for beta/ gamma-emitting radionuclides.

Low total suspended solids (TSS) levels result in a small amount of settleable solids, so an accurate measurement of radioactivity levels in settleable solids is impossible. Based on this, an interpretation of the radioactivity-levels-in-settleable-solids requirement was provided to SRS by DOE in 1995. The interpretation indicated that TSS levels below 40 parts per million ( $\mathrm{ppm}$ ) were considered to be in de-facto compliance with the DOE limits.

To determine compliance with these limits, EM uses TSS results - gathered as part of the routine National Pollutant Discharge Elimination System (NPDES) monitoring program - from outfalls co-located at or near radiological effluent points. If an outfall shows that TSS levels regularly are greater than $30 \mathrm{ppm}$, a radioactivity-levels-in-settleable-solids program and an increase in sediment monitoring will be implemented. 


\section{Surveillance Results Summary}

In 2008, only two NPDES TSS samples exceeded 30 ppm. Both samples were collected in March from sanitary waste facility outfall $\mathrm{K}-12$, with results of 80 and $51 \mathrm{ppm}$. These results were attributed to a plant upset resulting from a combination of factors, including infiltration of solids from nearby construction activities, a possible cement-like material being poured into the collection system, and inadequate aeration basin dissolved oxygen and mixing due in part to a faulty air diffuser head. Despite the two exceptions, the 2008 NPDES TSS results indicate that overall, SRS remains in compliance with the DOE radioactivity-levels-in-settleable-solids requirement.

\section{Sediment}

\section{Description of Surveillance Program}

Sediment sample analysis measures the movement, deposition, and accumulation of long-lived radionuclides in stream beds and in the Savannah River bed. Significant year-to-year differences may be evident because of the continuous deposition and remobilization occurring in the stream and river beds-or because of slight variation in sampling locationsbut the data obtained can be used to observe longterm environmental trends.

Sediment samples were collected at eight Savannah River and 13 site stream locations in 2008.

\section{Surveillance Results Summary}

Cesium-137 was the only manmade gamma-emitting radionuclide observed in river and stream sediments in 2008. The highest cesium-137 concentration in streams, 3.41E $+01 \mathrm{pCi} / \mathrm{g}$, was detected in sediment from R-Canal; the lowest levels were below detection at four locations. The highest level found on the river, $1.40 \mathrm{E}+00 \mathrm{pCi} / \mathrm{g}$, was at River Mile 150.2; the lowest levels were below detection at three locations. Generally, cesium-137 concentrations were higher in stream sediments than in river sediments. This is to be expected because the streams receive radionuclide-containing liquid effluents from the site. Most radionuclides settle out and deposit on the stream beds or at the streams' entrances to swamp areas along the river.

Strontium-89,90 was above the MDC in sediment at four stream locations in 2008. The maximum detected value was 2.06E-01 pCi/g at the Four Mile Creek at Road A-7A location.

Plutonium-238 was detected in sediment during 2008 at eight stream locations and five river locations. The results ranged from a maximum of $8.32 \mathrm{E}-02 \mathrm{pCi} / \mathrm{g}$ at FM-2A at Road 4 to below detection at several locations. Plutonium-239 was detected in sediment at 10 stream and three river locations. The maximum value was $2.55 \mathrm{E}-02 \mathrm{pCi} / \mathrm{g}$ - at FM-A7A. Uranium234 , uranium-235, and uranium-238 were detected at most locations.

The distribution and concentration of radionuclides in river sediment during 2008 were similar to those of previous years.

Concentrations of all isotopes generally were higher in streams than in the river. As indicated in the earlier discussion of cesium-137, this is to be expected. Differences observed when these data are compared to those of previous years probably are attributable to the effects of resuspension and depostion, which occur constantly in sediment media.

\section{Grassy Vegetation}

\section{Description of Surveillance Program}

The radiological program for grassy vegetation is designed to collect and analyze samples from onsite and offsite locations to determine radionuclide concentrations. Vegetation samples are obtained to complement the soil and sediment samples in order to determine the environmental accumulation of radionuclides and to help validate the dose models used by SRS. Bermuda grass is preferred because of its importance as a pasture grass for dairy herds.

Vegetation samples are obtained from

- locations containing soil radionuclide concentrations that are expected to be higher than normal background levels

- locations receiving water that may have been contaminated

- all air sampling locations 


\section{Surveillance Results Summary}

Radionuclides in the grassy vegetation samples collected in 2008 were detected as follows:

- tritium at four locations (one onsite. three perimeter)

- cesium-137 at four locations (perimeter)

- $\quad$ strontium-89,90 at eight locations (one onsite, six perimeter, 100-mile-radius)

- uranium-234 at one location (100-mile-radius)

- uranium-238 at one location (100-mile-radius)

- $\quad$ plutonium-239 at one location (perimeter)

- americium-241 at three locations (perimeter)

- gross beta at all 17 locations

- gross alpha at four locations (three perimeter, one 25-mile-radius)

Overall results show a slight decline in radionuclide concentrations during the past several years.

\section{Savannah River Swamp Surveys}

\section{Description of Surveillance Program}

The Creek Plantation, a privately owned land area located along the Savannah River, borders part of the southern boundary of SRS. In the 1960s, an area of the Savannah River Swamp on Creek Plantation-specifically, the area between Steel Creek Landing and Little Hell Landing - was contaminated by SRS operations. During high river levels, water from Steel Creek flowed along the lowlands comprising the swamp, resulting in the deposition of radioactive material. SRS studies estimated that a total of approximately $25 \mathrm{Ci}$ of cesium- 137 and $1 \mathrm{Ci}$ of cobalt- 60 were deposited in the swamp.

Comprehensive and cursory surveys of the swamp have been conducted periodically since 1974 . These surveys measure radioactivity levels to determine changes in the amount and/or distribution of radioactivity in the swamp. A series of 10 sampling trails - ranging from 240 to 3,200 feet in length- was established through the swamp. Fifty-four monitoring locations were designated on the trails to allow for continued monitoring at a consistent set of locations. [Fledderman, 2007]

The 2008 survey was designated as a cursory survey, requiring limited media sampling and analysis. Cursory surveys provide assurance that conditions observed during the more detailed comprehensive surveys have not changed significantly. A comprehensive survey requiring extensive media sampling and analyses was conducted in 2007.

\section{Surveillance Results Summary}

As anticipated, based on source term information and historical survey results, cesium-137 was the primary manmade radionuclide detected in the 2008 survey. Cesium-137 was detected in all soil samples while cobalt-60 was detected in one soil sample. Cesium-137 concentrations varied from a low of $0.20 \mathrm{pCi} / \mathrm{g}$ to a high of $47.50 \mathrm{pCi} / \mathrm{g}$. These levels are comparable with results of previous surveys. Examination of the 10 shallow core samples showed that in general, higher concentrations of cesium-137 were observed in the shallow depths. Increased activity was observed as far away as trail 10 , while higher concentrations were present on trails 1 and 4 .

Cesium-137 was detected in all 10 vegetation samples. Concentrations varied from a minimum of $0.29 \mathrm{pCi} / \mathrm{g}$ to a maximum of $7.30 \mathrm{pCi} / \mathrm{g}$. These levels are comparable with results of previous surveys. Higher concentrations generally were observed on trails 4, 5, and 8. No relationship was observed between soil and vegetation samples; however, the samples were collected at different times of the year. There was no detectable strontium- 90 or cobalt- 60 in the vegetation samples.

\section{Nonradiological Surveillance}

\section{Air}

SRS does not conduct onsite surveillance for nonradiological ambient air quality. However, to ensure compliance with SCDHEC air quality regulations and standards, SRNL most recently conducted air dispersion modeling for all site sources of criteria pollutants and toxic air pollutants in 2001. This modeling indicated that all SRS sources were in compliance with air quality regulations and stan- 
dards. Since that time, additional modeling conducted for new sources of criteria pollutants and toxic air pollutants has demonstrated continued compliance by the site with current applicable regulations and standards. The states of South Carolina and Georgia continue to monitor ambient air quality near the site as part of a network associated with the federal Clean Air Act.

\section{Surface Water}

SRS streams and the Savannah River are classified by SCDHEC as "Freshwaters," which are defined as surface water suitable for

- primary and secondary contact recreation and as a drinking water source after conventional treatment in accordance with SCDHEC requirements

- fishing and survival and propagation of a balanced indigenous aquatic community of fauna and flora

- industrial and agricultural uses

Appendix A ("Applicable Guidelines, Standards, and Regulations") of this report provides some of the specific guidelines used in water quality surveillance, but because some of these guidelines are not quantifiable, they are not tracked at SRS.

\section{Surveillance Results Summary}

Most water quality parameters and metals were detected in at least one sample at every location. Four samples (two from an onsite stream and two from the Savannah River) had detectable pesticides/herbicides in 2008. These results continue to indicate that SRS discharges are not significantly affecting the water quality of onsite streams or the river.

\section{Drinking Water}

Most of the drinking water at SRS is supplied by three systems that have treatment plants in A-Area, D-Area, and K-Area. The site also has 14 small drinking water facilities, each of which serves populations of fewer than 25 persons.

\section{Surveillance Results Summary}

All samples collected from SRS drinking water systems during 2008 were in compliance with SCDHEC and EPA water quality standards. Additional information is provided in the Safe Drinking Water Act section of chapter 3, "Environmental Compliance."

\section{Sediment}

The nonradiological sediment surveillance program provides a method to determine the deposition, movement, and accumulation of nonradiological contaminants in stream systems. Sample preparation prior to analysis was changed in 2007 from an extraction (toxicity characteristic leaching procedure, or TCLP) to a total sample digestion.

\section{Surveillance Results Summary}

In 2008, as in the previous 5 years, no pesticides or herbicides were found to be above the quantitation limits in sediment samples. Metals analyses results for 2008 also were comparable to those of the previous 5 years.

\section{Fish}

EM personnel analyze the flesh of fish caught from the Savannah and Edisto Rivers to determine concentrations of mercury in the fish. In 2008, the addition of metals (arsenic, cadmium, manganese, and antimony) to the analytical suite was completed. The fish analyzed represent the most common edible species of fish in the CSRA (freshwater) and at the mouth of the Savannah River (saltwater).

\section{Surveillance Results Summary}

In 2008, mercury analyses were performed on 336 fish from the Savannah River and 15 from the Edisto River at West Bank Landing. Concentrations of mercury generally were slightly lower than those observed in 2007. The highest concentrations were found in the Savannah River - in bass at the Highway 301 Bridge Area (1.205 $\mu \mathrm{g} / \mathrm{g})$, in catfish at Stokes Bluff $(0.871 \mu \mathrm{g} / \mathrm{g})$, and in bream at the Highway 301 Bridge Area $(0.853 \mu \mathrm{g} / \mathrm{g})$. The highest 
concentrations found at West Bank Landing were $1.037 \mu \mathrm{g} / \mathrm{g}$ in bass, $0.940 \mu \mathrm{g} / \mathrm{g}$ in bream, and 0.536 $\mu \mathrm{g} / \mathrm{g}$ in catfish.

Arsenic was detected in sixteen samples, with the highest concentration in spottail bass $(1.46 \mu \mathrm{g} / \mathrm{g})$ at RM-08 of the Savannah River. Cadmium was below detection in all samples. Manganese was detected at all locations, with the highest concentration in bream $(5.13 \mu \mathrm{g} / \mathrm{g})$ at the mouth of Lower Three Runs. Antimony was detected in 63 samples, with the highest concentration in bream $(1.09 \mu \mathrm{g} / \mathrm{g})$ at the mouth of Steel Creek.

\section{River Water Quality Surveys}

\section{Description of Surveys}

Academy of Natural Sciences (ANS) personnel conducted biological and water quality surveys of the Savannah River from 1951 through 2003, when EM assumed this responsibility. The surveys were designed to assess potential effects of SRS contaminants and warm-water discharges on the general health of the river and its tributaries. This is accom- plished by looking for

- patterns of biological disturbance geographically associated with the site

- patterns of change over seasons or years that indicate improving or deteriorating conditions

EM conducted macroinvertebrate sampling during the spring and fall of 2008, and diatom sampling was conducted monthly. The diatom slides were sent to ANS for archiving. No adverse biological impacts have been identified in the Savannah River diatom communities.

Macroinvertebrates collected from river traps during 2007 were similar in species diversity to those documented in surveys during the 1990s. An overall decrease in total populations was observed that likely is associated with low flow in the river and incipient drought conditions. No evidence of adverse biological impacts was found in the observed macroinvertebrate communities. Collections from 2008 will be sorted and archived during 2009. 



\title{
Potential Radiation Doses
}

\author{
G. Timothy Jannik, Eduardo B. Farfan, Trevor Q. Foley, and Patricia L. Lee \\ Savannah River National Laboratory
}
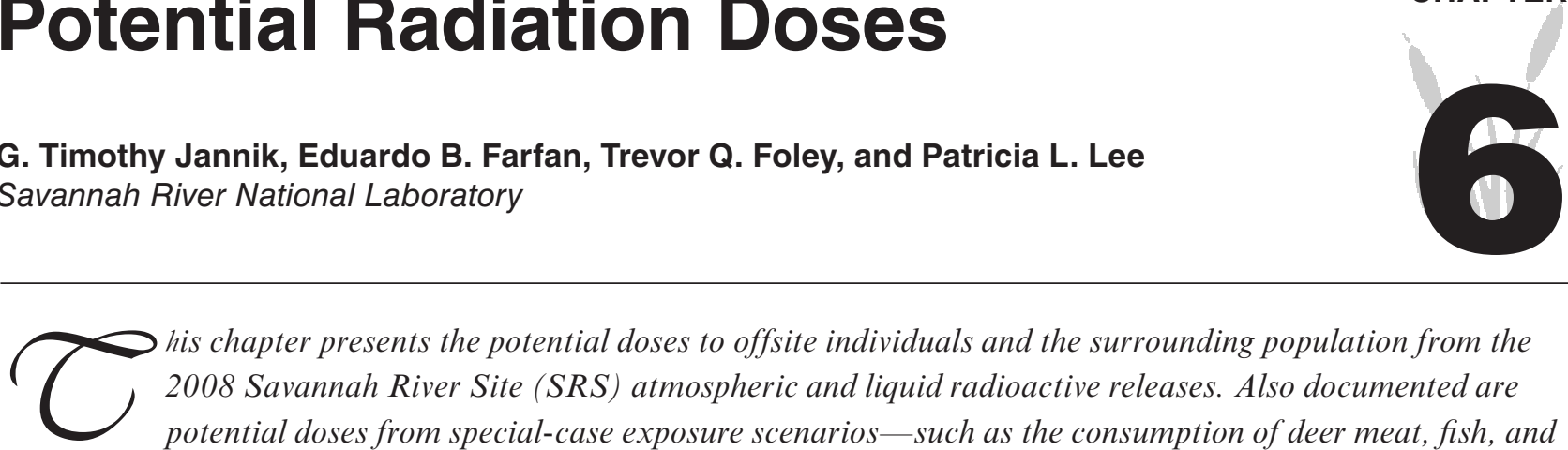

his chapter presents the potential doses to offsite individuals and the surrounding population from the

2008 Savannah River Site (SRS) atmospheric and liquid radioactive releases. Also documented are potential doses from special-case exposure scenarios - such as the consumption of deer meat, fish, and goat milk. Unless otherwise noted, the generic term "dose" used in this report includes both the committed effective dose equivalent (50-year committed dose) from internal deposition of radionuclides and the effective dose equivalent attributable to sources external to the body. Use of the effective dose equivalent allows doses from different types of radiation and to different parts of the body to be expressed on the same basis.

Descriptions of the SRS effluent monitoring and environmental surveillance programs discussed in this chapter can be found in chapter 4, "Effluent Monitoring," and chapter 5, "Environmental Surveillance." A complete description of how potential doses are calculated can be found in section 1108 of the Savannah River Site Environmental Monitoring Program, WSRC-3Q1-2, Volume 1, Revision 4 [SRS EM Program, 2002].

All dose calculation results are presented in data tables on the $\mathrm{CD}$ accompanying this report.

\section{Calculating Dose}

Potential offsite doses from SRS effluent releases of radioactive materials (atmospheric and liquid) are calculated for the following scenarios:

- hypothetical maximally exposed individual living at the SRS boundary

- $\quad$ population living within an $80-\mathrm{km}$ (50-mile) radius of SRS

\section{Dose to the Hypothetical Maximally Exposed Individual}

When calculating radiation doses to the public, SRS uses the concept of the hypothetical maximally exposed individual; however, because of the conservative lifestyle assumptions used in the dose models, no such person is known to exist. The parameters used for the dose calculations are as follows:

For airborne releases - Someone who lives at the SRS boundary 365 days per year and consumes milk, meat, and vegetables produced at that location

For liquid releases - Someone who lives downriver of SRS (near River Mile 118.8) 365 days per year, drinks 2 liters of untreated water per day from the Savannah River, consumes $19 \mathrm{~kg}$ (42 pounds) per year of Savannah River fish, and spends the majority of time on or near the river

To demonstrate compliance with the DOE Order 5400.5 all-pathway dose standard of 100 mrem per year, SRS conservatively combines the airborne pathway and liquid pathway dose estimates, even though the two doses are calculated for hypothetical individuals residing at different geographic locations 
Because the U.S. Department of Energy (DOE) has adopted dose factors only for adults [DOE, 1988], SRS calculates maximally exposed individual and collective doses as if the entire $80-\mathrm{km}$ population consists of adults. For the radioisotopes that contribute the most to SRS's estimated maximum individual doses (i.e., tritium and cesium-137), the dose to infants could be approximately two to three times more than to adults. The dose to older children becomes progressively closer to the adult dose.

SRS also uses adult consumption rates for food and drinking water and adult usage parameters to estimate intakes of radionuclides. These intake values and parameters were developed specifically for SRS based on a regional survey [Hamby, 1991].

For dose calculations, the unspecified alpha releases were conservatively treated as plutonium-239, and the unspecified beta releases were treated as strontium-90. These radionuclides have the highest dose factors of the alpha- and beta-emitters, respectively, that are commonly measured in SRS waste streams.

\section{Dose Calculation Methods}

To calculate annual offsite doses, SRS uses transport and dose models developed for the commercial nuclear industry [NRC, 1977]. The models are described in SRS EM Program, 2002.

\section{Meteorological Database}

To show compliance with DOE environmental orders, potential offsite doses from releases of radioactivity to the atmosphere were calculated with quality-assured meteorological data for A-Area, K-Area (for combined releases from C-Area, K-Area, and L-Area), and H-Area (for combined releases from all other areas). The meteorological databases were for the years 2002-2006, reflecting the most recent 5-year compilation period.

To show compliance with U.S. Environmental Protection Agency (EPA) regulations, only the H-Area database was used in the calculations because the EPA-required dosimetry code (CAP88, Mainframe version 1.0, henceforth referred to simply as CAP88) is limited to a single release location.

\section{Population Database and Distribution}

Collective (population) doses from atmospheric releases are calculated for the population within an $80-\mathrm{km}$ radius of SRS. Within this radius, the total population is 713,500 , based on 2000 census data.

Some of the collective doses resulting from SRS liquid releases are calculated for the populations served by the City of Savannah Industrial and Domestic Water Supply Plant (Savannah I\&D), near Port Wentworth, Georgia, and by the Beaufort-Jasper Water and Sewer Authority's (BJWSA) Chelsea and Purrysburg Water Treatment Plants, near Beaufort, South Carolina. According to the treatment plant operators, the population served by the Savannah I\&D facility during 2008 was 26,300 persons, while the population served by the BJWSA Chelsea facility was 77,000 persons and by the BJWSA Purrysburg facility, 58,000 persons.

\section{River Flow Rate Data}

Savannah River flow rates - recorded at a gauging station near River Mile 118.8 (U.S. Highway 301 bridge) - are based on the measured water elevation. However, these data are not used directly in dose calculations. Used instead are "effective" flow rates, which are based on (1) the measured annual release of tritium and (2) the annual average tritium concentrations measured at River Mile 118.8 and at the three downriver water treatment plants. The use of effective river flow rates in the dose calculations generally is more conservative than the use of measured flow rates because it accounts for less dilution.

For 2008, the River Mile 118.8 calculated (effective) flow rate of 4,340 cubic feet per second (cfs) was used in the dose calculations. This flow rate was nearly 20 percent less than the 2007 effective flow rate of 5,390 cfs. For comparison, the 2008 measured annual average flow rate was $4,830 \mathrm{cfs}$. This was the lowest measured annual average river flow rate since the startup of SRS operations in 1954. The low flow is attributed to water conservation measures taken by the U.S. Army Corps of Engineers at the upriver dams in response to the continuing drought conditions in the Savannah River basin area.

The 2008 effective flow rates were $5,150 \mathrm{cfs}$ for the 
Savannah I\&D facility, 5,890 cfs for the BJWSA Chelsea facility, and 5,180 cfs for the BJWSA Purrysburg facility.

\section{Dose Calculation Results}

\section{Liquid Pathway}

\section{Liquid Release Source Terms}

The 2008 radioactive liquid release quantities used as the source term in SRS dose calculations are discussed in chapter 4 and shown by radionuclide in table 6-1. Tritium accounts for more than 99 percent of the total amount of radioactivity released from the site to the Savannah River. In 2008, a total of 1,530 curies of tritium were released from SRS to the river. In the recent past, the total amount of tritium used in SRS dose calculations was based on the measured tritium concentration at River Mile 118.8. However, the total from this location includes the tritium releases from Georgia Power Company's Vogtle Electric Generating Plant (VEGP). Since 2006, maximally-exposed-individual doses have been calculated and documented in this report using SRS-only releases.

Data from continuously monitored liquid effluent discharge points are used in conjunction with site seepage basin and Solid Waste Disposal Facility migration release measurements to quantify the total tritium released from SRS. A separate dose calculation is performed (for information only) that includes the total amount of tritium (SRS plus VEGP) measured at River Mile 118.8, which in 2008 was 2,660 curies.

\section{Radionuclide Concentrations in Savannah River Water, Drinking Water, and Fish}

The concentrations of tritium in Savannah River water and cesium-137 in Savannah River fish are measured at several locations along the river for use in dose determinations and model comparisons. The amounts of all other radionuclides released from SRS are so small that they usually cannot be detected in the Savannah River using conventional analytical techniques. Therefore, their concentrations in the river are calculated using the LADTAP XL code, based on the annual release amounts and on the applicable effective flow rate.
Radionuclide Concentrations in River Water and Treated Drinking Water The measured concentrations of tritium in the Savannah River near River Mile 118.8 and at the Savannah I\&D and BJWSA water treatment facilities are shown in table $6-1$, as are the calculated concentrations for the other released radionuclides. These downriver tritium concentrations include the tritium releases from SRS and the neighboring VEGP.

In 2008, the 12-month average tritium concentration measured in Savannah River water near River Mile $118.8(0.686 \mathrm{pCi} / \mathrm{mL})$ was 70 percent more than the 2007 concentration of $0.403 \mathrm{pCi} / \mathrm{mL}$. This increase was because of the record low flow rate in the Savannah River during 2008, and because the combined total amount of tritium released from SRS and VEGP increased from 1,940 curies in 2007 to 2,660 curies in 2008 . The 2008 concentrations at the BJSWA Chelsea $(0.506 \mathrm{pCi} / \mathrm{mL})$ and Purrysburg $(0.575 \mathrm{pCi} / \mathrm{mL})$ facilities, and at the Savannah I\&D $(0.578 \mathrm{pCi} / \mathrm{mL})$ water treatment plant, were higher than in 2007 but remained below the EPA drinking water maximum contaminant level (MCL) of $20 \mathrm{pCi} /$ $\mathrm{mL}$.

The drinking water MCL for each radionuclide released from SRS during 2008 is provided in table $6-1$. The table indicates that all individual radionuclide concentrations at the three downriver community drinking water systems, as well as at River Mile 118.8, were below the MCLs.

Because more than one radionuclide is released from SRS, the sum of the fractions of the reported concentration of each radionuclide to its corresponding MCL must not exceed 1.0. The sums of the fractions were 0.0317 at the BJSWA Chelsea facility, 0.0360 at the BJSWA Purrysburg facility, and 0.0362 at the Savannah I\&D facility. These are below the 1.0 sumof-the-fractions requirement.

For 2008, the sum of the fractions at the River Mile 118.8 location was 0.0427 . This is provided only for comparison because River Mile 118.8 is not a community water system location.

Radionuclide Concentrations in River Fish At SRS, an important dose pathway for the maximally exposed individual is from the consumption of fish. 
Table 6-1

2008 Radioactive Liquid Release Source Term and 12-Month Average Downriver Radionuclide Concentrations Compared to EPA's Drinking Water Maximum Contaminant Levels (MCLs)

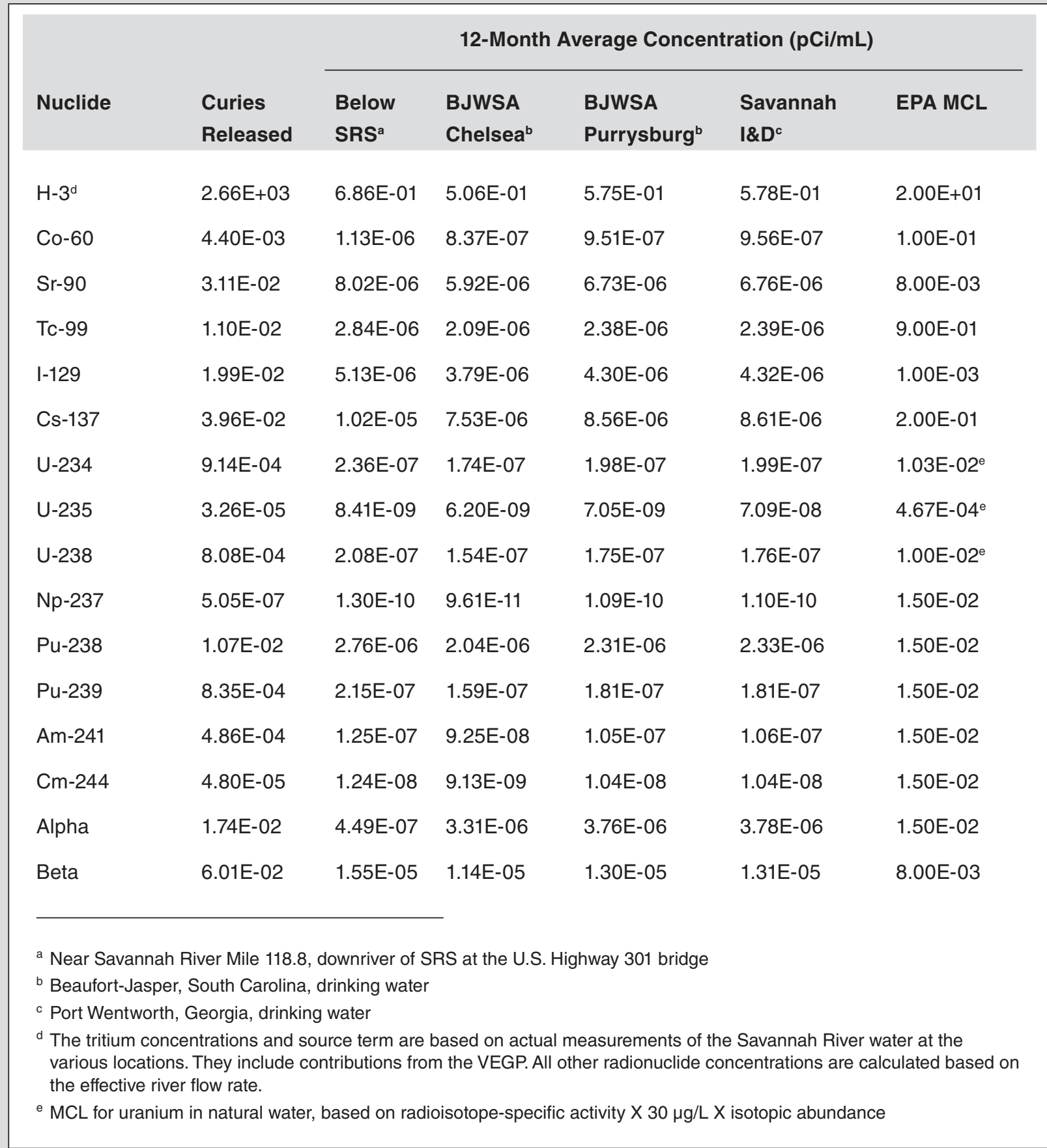

Fish exhibit a high degree of bioaccumulation for certain elements. For the element cesium (including radioactive isotopes of cesium), the bioaccumulation factor for Savannah River fish is approximately
3,000 . That is, the concentration of cesium found in fish flesh is about 3,000 times the concentration of cesium found in the water in which the fish live [Carlton et al., 1994]. 
Because of this high bioaccumulation factor, cesium137 is detected more easily in fish flesh than in river water. Therefore, the fish pathway dose from cesium137 normally is based directly on the radioanalysis of the fish collected near Savannah River Mile 118.8, which is the assumed location of the hypothetical maximally exposed individual. However, in 2008, the calculated concentration of cesium-137 in fish, which is based on measured effluent releases, was determined to be more than the actual measured concentration in fish. To be conservative, the higher calculated cesium-137 concentration in fish was used in the 2008 dose determinations.

\section{Dose to the Maximally Exposed Individual}

As shown in table 6-2, the highest potential dose to the maximally exposed individual from liquid releases in 2008 was estimated at $0.08 \mathrm{mrem}(0.0008 \mathrm{mSv})$. This dose is 0.08 percent of the DOE Order 5400.5 ("Radiation Protection of the Public and the Environment") 100-mrem all-pathway dose standard for annual exposure. The 2008 dose is about 60 percent more than the 2007 dose of 0.05 mrem $(0.0005 \mathrm{mSv})$. This increase is attributed primarily to (1) the record low annual average Savannah River flow rate during 2008 (which caused less dilution to occur), and (2) increased releases of plutonium-238 from H-Area, caused by an episodic operational release.

Approximately 38 percent of the 2008 dose to the maximally exposed individual resulted from the ingestion of cesium-137, mainly from the consumption of fish. About 24 percent of the dose resulted from the ingestion of tritium (mainly via drinking water), an additional 19 percent from the ingestion of unspecified alpha emitters, and 11 percent from the ingestion of plutonium-238. Every other radionuclide contributed less than 3 percent to the dose.

Using the 2008 total tritium source term (which includes SRS and VEGP releases measured at River Mile 118.8) of 2,660 curies, the maximally-exposedindividual dose was calculated to be $0.09 \mathrm{mrem}$ $(0.0009 \mathrm{mSv})$. This dose is 50 percent more than the equivalent 2007 dose of $0.06 \mathrm{mrem}(0.0006 \mathrm{mSv})$.

\section{Drinking Water Pathway Dose}

Persons downriver of SRS may receive a radiation dose by consuming drinking water that contains radioactivity as a result of liquid releases from the site. In 2008, tritium in downriver drinking water represented the majority of the dose (about 40 percent) received by persons at the three downriver water treatment plants. Unspecified alpha-emitters accounted for about 33 percent, and plutonium-238 releases accounted for about 17 percent.

Based on SRS-only releases, the maximum potential drinking water dose during 2008 was determined to be $0.04 \mathrm{mrem}(0.0004 \mathrm{mSv})$ - about 100 percent more

Table 6-2

Potential Dose to the Maximally Exposed Individual from SRS Liquid Releases in 2008

\begin{tabular}{|c|c|c|c|}
\hline & $\begin{array}{c}\text { Committed } \\
\text { Dose (mrem) }\end{array}$ & $\begin{array}{c}\text { Applicable } \\
\text { Standard (mrem) }\end{array}$ & $\begin{array}{c}\text { Percent } \\
\text { of Standard }\end{array}$ \\
\hline \multicolumn{4}{|l|}{ Maximally Exposed Individual } \\
\hline Near Site Boundary (all liquid pathways) & 0.08 & $100^{\mathrm{a}}$ & 0.08 \\
\hline At BJSWA Chelsea (public water supply only) & 0.03 & $4^{\mathrm{b}}$ & 0.80 \\
\hline At BJSWA Purrysburg (public water supply only) & 0.04 & $4^{\mathrm{b}}$ & 1.00 \\
\hline At Savannah I\&D (public water supply only) & 0.04 & $4^{\mathrm{b}}$ & 1.00 \\
\hline \multicolumn{4}{|c|}{ a All-pathway dose standard: 100 mrem per year (DOE Order 5400.5) } \\
\hline \multicolumn{4}{|c|}{${ }^{b}$ Drinking water pathway standard: 4 mrem per year (DOE Order 5400.5) } \\
\hline
\end{tabular}


than the 2007 dose of $0.02 \mathrm{mrem}(0.0002 \mathrm{mSv})$. This increase is attributed primarily to the low Savannah River flow rate and to increased releases of plutonium-238. As shown in table 6-2, the maximum dose of $0.04 \mathrm{mrem}$ is 1.0 percent of the DOE standard of 4 mrem per year for public water supplies.

Using the SRS-plus-VEGP total tritium source term of 2,660 curies, the maximum drinking water dose was calculated to be $0.05 \mathrm{mrem}(0.0005 \mathrm{mSv})$ in 2008 .

\section{Collective (Population) Dose}

The collective drinking water consumption dose is calculated for the discrete population groups served by the BJWSA and Savannah I\&D water treatment plants. The collective dose from other pathways is calculated for a diffuse population that makes use of the Savannah River; however, this population cannot be described as being in a specific geographical location.

In 2008, the collective dose from SRS liquid releases was estimated at 3.8 person-rem ( 0.038 person-Sv). This is about 80 percent more than the 2007 collective dose of 2.1 person-rem ( 0.021 person-Sv). Again, this increase is attributed mainly to the low Savannah River flow rate and to increased releases of plutonium-238.

Using the SRS-plus-VEGP total tritium source term of 2,660 curies, the collective dose was calculated to be 4.7 person-rem (0.047 person-Sv) in 2008 .

\section{Potential Dose from Agricultural Irrigation}

Based on surveys of county agricultural extension agencies, there are no known large-scale uses of Savannah River water downstream of SRS for agricultural irrigation purposes [Hamby, 1991]. However, the potential for irrigation does exist, so potential doses from this pathway are calculated for information purposes only but are not included in calculations of the official maximally-exposed-individual or collective doses.

As in previous years, collective doses from agricultural irrigation were calculated for 1,000 acres of land devoted to each of four major food typesvegetation, leafy vegetation, milk, and meat. It is assumed that all the food produced on the 1,000-acre parcels is consumed by the population $(713,500)$ within $80 \mathrm{~km}$ of SRS.
For 2008, a potential offsite dose of $0.1 \mathrm{mrem}(0.001$ $\mathrm{mSv}$ ) to the maximally exposed individual and a collective dose of 6.3 person-rem ( 0.063 person-Sv) were estimated for this exposure pathway.

\section{Air Pathway}

\section{Atmospheric Source Terms}

The 2008 radioactive atmospheric release quantities used as the source term in SRS dose calculations are discussed in chapter 4. Estimates of unmonitored diffuse and fugitive sources were included in the atmospheric source term, as required, for demonstrating compliance with National Emission Standards for Hazardous Air Pollutants (NESHAP) regulations.

\section{Atmospheric Concentrations}

Calculated radionuclide concentrations instead of measured concentrations are used for dose determinations. This is because most radionuclides released from SRS cannot be measured (using conventional analytical methods) in the air samples collected at the site perimeter and offsite locations. However, the concentrations of tritium oxide at the site perimeter locations usually can be measured - and are compared with calculated concentrations as a verification of the dose models.

\section{Dose to the Maximally Exposed Individual}

In 2008, the estimated dose from atmospheric releases to the maximally exposed individual (calculated with MAXDOSE-SR) was 0.04 mrem (0.0004 $\mathrm{mSv}$ ), which is 0.4 percent of the DOE Order 5400.5 air pathway standard of 10 mrem per year. Table 6-3 compares the maximally-exposed-individual dose with the DOE standard. The 2008 dose was the same as the dose for 2007.

Tritium oxide releases accounted for about 82 percent of the dose to the maximally exposed individual, and iodine-129 releases accounted for about 11 percent of the dose. No other individual radionuclide accounted for more than 2 percent of the maximally-exposed-individual dose.

The major pathways contributing to the maximallyexposed-individual dose from atmospheric releases were inhalation (43 percent), vegetation consumption 
Table 6-3

Potential Dose to the Maximally Exposed Individual from SRS Atmospheric Releases in 2008

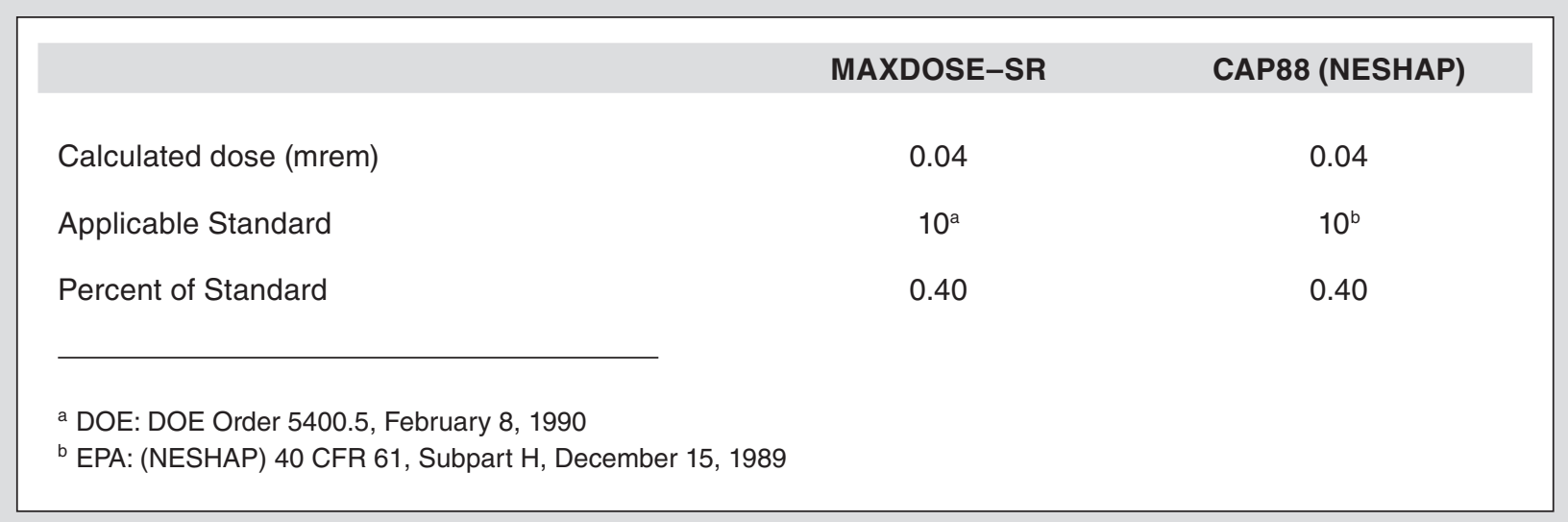

(39 percent), and meat and milk consumption (17 percent). For 2008, the north sector of the site was the location of the highest dose to the maximally exposed individual.

Additional calculations of the dose to the maximally exposed individual again were performed substituting goat milk for the customary cow milk pathway. The potential dose to the maximally exposed individual using the goat milk pathway instead of the cow milk pathway was estimated at 0.05 mrem (0.0005 mSv).

\section{Collective (Population) Dose}

In 2008, the airborne-pathway collective dose (calculated with POPDOSE-SR) was estimated at 1.8 person-rem $(0.018$ person-Sv)-less than 0.01 percent of the annual collective dose received from natural sources of radiation (about 214,000 personrem). Tritium oxide releases accounted for about 86 percent of the collective dose. The 2008 collective dose was the same as the 2007 dose.

\section{NESHAP Compliance}

To demonstrate compliance with NESHAP regulations [EPA, 2002], maximally-exposed-individual and collective doses were calculated using (1) the CAP88 computer code, (2) the 2008 airborne-release source term, and 3) site-specific input parameters [SRS EM Program, 2002]. The CAP88 code estimates a higher dose for tritium oxide than do the MAXDOSE-SR and POPDOSE-SR codes, which are used for demonstrating compliance with DOE environmental orders. Most of the differences occur in the tritium dose estimated from food consumption. The major cause of this difference is the CAP88 code's use of 100-percent equilibrium between tritium in air moisture and tritium in food moisture, whereas the MAXDOSE-SR and POPDOSE-SR codes use 50-percent equilibrium values, as recommended by the Nuclear Regulatory Commission [NRC, 1977]. A site-specific study indicated that the 50 -percent value is correct for the atmospheric conditions at SRS [Hamby and Bauer, 1994].

Because tritium oxide dominates the doses determined using the CAP88 code, other radionuclides (such as iodine-129) are less important - on a percentage-of-dose basis - for the CAP88 doses than for the MAXDOSE-SR and POPDOSE-SR doses.

For 2008, the maximally-exposed-individual dose was estimated at $0.04 \mathrm{mrem}(0.0004 \mathrm{mSv})$, which is 0.4 percent of the 10 -mrem-per-year EPA standard, as shown in table 6-3. Tritium oxide releases accounted for about 97 percent of this dose.

For NESHAP, the dose from diffuse and fugitive releases is required to be reported separately. For 2008, the maximally-exposed-individual dose from diffuse and fugitive releases was estimated to be 0.01 mrem $(0.0001 \mathrm{mSv})$, which accounts for slightly less than half the total maximally-exposed-individual dose.

The CAP88-determined collective dose was estimated at 4.6 person-rem (0.046 person-Sv). Tritium oxide releases accounted for about 98 percent of this dose. 


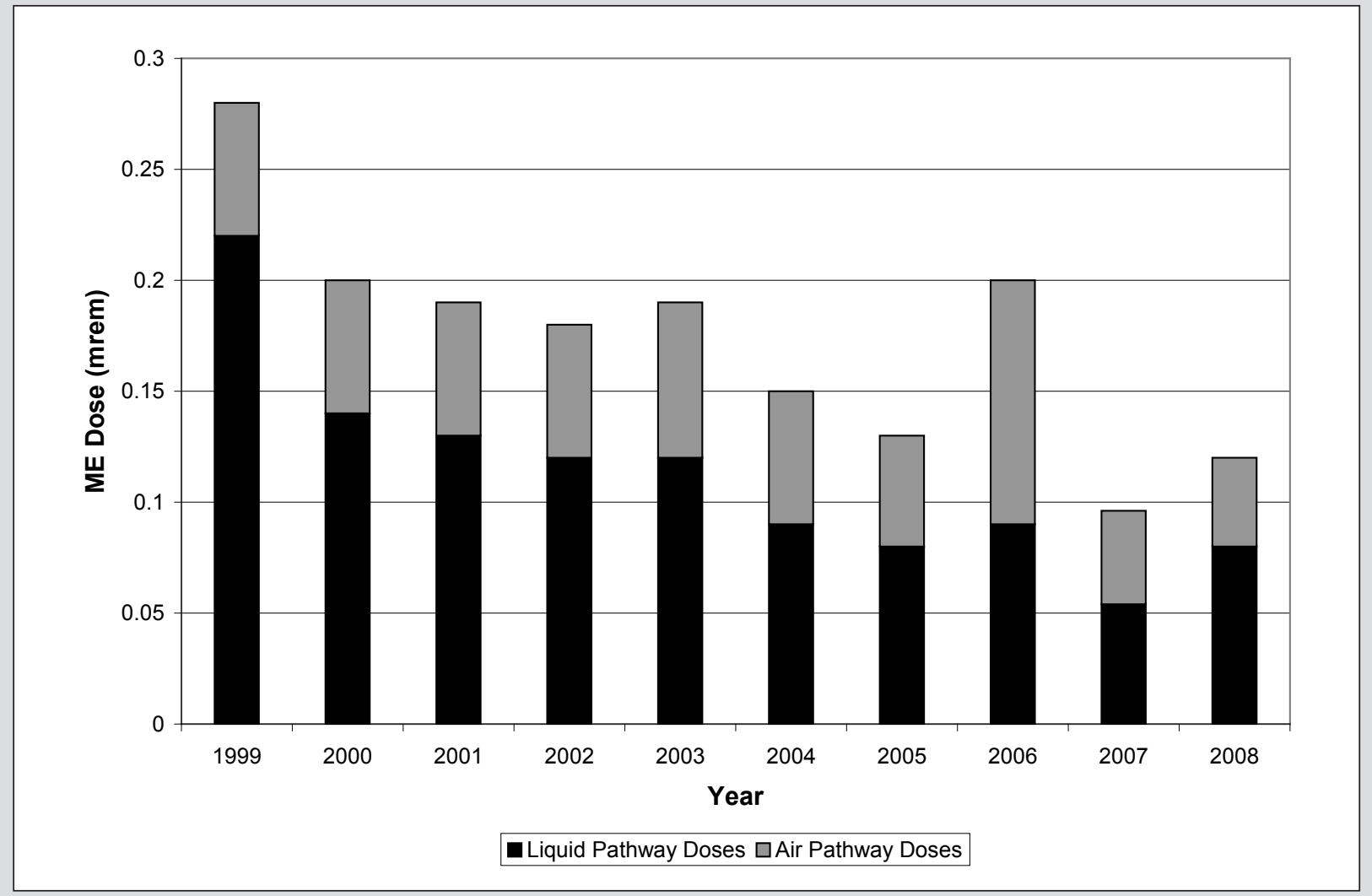

Figure 6-1 Ten-Year History of SRS Maximum Potential All-Pathway Doses

\section{All-Pathway Dose}

To demonstrate compliance with the DOE Order 5400.5 all-pathway dose standard of 100 mrem (1.0 $\mathrm{mSv}$ ) per year, SRS conservatively combines the maximally exposed individual airborne pathway and liquid pathway dose estimates, even though the two doses are calculated for hypothetical individuals residing at different geographic locations.

For 2008, the potential maximally exposed individual all-pathway dose was $0.12 \mathrm{mrem}(0.0012 \mathrm{mSv})$ $0.04 \mathrm{mrem}$ from air pathways plus 0.08 mrem from liquid pathways. The all-pathway dose is 0.12 percent of the 100-mrem-per-year DOE dose standard. The 2008 dose is 20 percent more than the 2007 allpathway dose of $0.10 \mathrm{mrem}(0.001 \mathrm{mSv})$. As previously discussed, this increase is attributed primarily to the record low Savannah River flow rate and to increased liquid releases of plutonium-238.

Figure 6-1 shows a 10-year history of SRS's all-pathway (airborne pathway plus liquid pathway) doses to the maximally exposed individual.

\section{Sportsman Dose}

DOE Order 5400.5 specifies radiation dose standards for individual members of the public. The dose standard of 100 mrem per year includes doses a person receives from routine DOE operations through all exposure pathways. Nontypical exposure pathways - not included in the standard calculations of the doses to the maximally exposed individual — are considered and quantified separately. This is because they apply to low-probability scenarios, such as consumption of fish caught exclusively from the mouths of SRS streams, or to unique scenarios, such as volunteer deer hunters.

In addition to deer, hog, and fish consumption, the following exposure pathways were considered for an offsite hunter and an offsite fisherman - both on Creek Plantation, a privately owned portion of the Savannah River Swamp, which was contaminated by SRS operations in the 1960s (chapter 5):

\section{- External exposure to contaminated soil}


- Incidental ingestion of contaminated soil

- Incidental inhalation of resuspended contaminated soil

\section{Onsite Hunter Dose}

Deer and Hog Consumption Pathway Annual hunts, open to members of the general public, are conducted at SRS to control the site's deer and feral hog populations and to reduce animal-vehicle ac- cidents. The estimated dose from the consumption of harvested deer or hog meat is determined for every onsite hunter. During 2008, the maximum dose that could have been received by an actual onsite hunter was estimated at $13 \mathrm{mrem}(0.13 \mathrm{mSv})$, or 13 percent of DOE's 100-mrem all-pathway dose standard (table 6-4). This dose was determined for an actual hunter who in fact harvested six animals (all deer) during the 2008 hunts. The hunter-dose calculation is based on the conservative assumption that this prolific hunter individually consumed the entire edible

Table 6-4

2008 Maximum Potential All-Pathway and Sportsman Doses Compared to the DOE All-Pathway Dose Standard

\section{Committed Applicable Percent \\ Dose (mrem) Standard (mrem) a ${ }^{\text {a }}$ Standard}

\section{Maximally-Exposed-Individual Dose}

All-Pathway

(Liquid Plus Airborne Pathway)

0.12

100

0.12

Sportsman Dose

Onsite Hunter

13.00

0.11

100

13.00

Creek-Mouth Fisherman ${ }^{b}$

Savannah River Swamp Hunter

Offsite Hog Consumption

Offsite Deer Consumption

5.70

Soil Exposure ${ }^{\mathrm{c}}$

2.90

Total Offsite Deer Hunter Dose

8.60

100

8.60

Savannah River Swamp Fisherman

Steel Creek Fish Consumption

0.09

Soil Exposure ${ }^{d}$

0.28

Total Offsite Fisherman Dose
0.37

100

0.37

a All-pathway dose standard: 100 mrem per year (DOE Order 5400.5)

b In 2008, the maximum dose to a hypothetical fisherman was caused by the consumption of catfish from the mouth of Upper Three Runs.

${ }^{c}$ Includes the dose from a combination of external exposure to-and incidental ingestion and inhalation of the worst-case Savannah River Swamp soil

${ }^{d}$ Includes the dose from a combination of external exposure to-and incidental ingestion and inhalation of Savannah River Swamp soil near the mouth of Steel Creek 
portion - approximately $164 \mathrm{~kg}$ (362 pounds) — of the animals he harvested from SRS.

\section{Offsite Hunter Dose}

Deer and Hog Consumption Pathway The deer and hog consumption pathway considered was for hypothetical offsite individuals whose entire intake of meat during the year was either deer or hog meat. It was assumed that these individuals harvested deer or hogs that had resided on SRS, but then moved off site.

Based on these low-probability assumptions and on the measured average concentration of cesium-137 in all deer $(2.40 \mathrm{pCi} / \mathrm{g})$ and hogs $(2.91 \mathrm{pCi} / \mathrm{g})$ harvested from SRS during 2008, the potential maximum doses from this pathway were estimated at $5.7 \mathrm{mrem}(0.057$ $\mathrm{mSv}$ ) for the offsite deer hunter and $7.7 \mathrm{mrem}(0.077$ $\mathrm{mSv}$ ) for the offsite hog hunter.

A background cesium- 137 concentration of $1 \mathrm{pCi} / \mathrm{g}$ is subtracted from the onsite average concentrations before calculating the doses. The background concentration is based on previous analyses of deer harvested at least $80 \mathrm{~km}$ from SRS (table 33, SRS Environmental Data for 1994, WSRC-TR-95-077).

\section{Savannah River Swamp Hunter Soil Exposure} Pathway The potential dose to a recreational hunter exposed to SRS legacy contamination in Savannah River Swamp soil on the privately owned Creek Plantation in 2008 was estimated using the RESRAD code [Yu et al., 2001]. It was assumed that this recreational sportsman hunted for 120 hours during the year ( 8 hours per day for 15 days) at the location of maximum radionuclide contamination.

Using the worst-case radionuclide concentrations from the most recent comprehensive survey-conducted in 2007- the potential dose to a hunter from a combination of (1) external exposure to the contaminated soil, (2) incidental ingestion of the soil, and (3) incidental inhalation of resuspended soil was estimated to be 2.9 mrem $(0.029 \mathrm{mSv})$.

As shown in table 6-4, the offsite deer consumption pathway and the Savannah River Swamp hunter soil exposure pathway were conservatively added together to obtain a total offsite hunter dose of 8.6 mrem $(0.086 \mathrm{mSv})$. This potential dose is 8.6 percent of the DOE 100-mrem all-pathway dose standard.

\section{Offsite Fisherman Dose}

Creek-Mouth Fish Consumption Pathway For 2008, radioanalyses were conducted of three species of fish (panfish, catfish, and bass) taken from the mouths of the five SRS streams, and the resulting estimated doses were calculated. SRS reports the maximum dose from this combination of fish and creek mouths. As shown in table 6-4, the maximum potential dose from this pathway was estimated at $0.11 \mathrm{mrem}(0.0011 \mathrm{mSv})$ - from the consumption of catfish collected at the mouth of Upper Three Runs. This hypothetical dose is based on the low-probability scenario that, during 2008, a fisherman consumed $19 \mathrm{~kg}$ of catfish caught exclusively from the mouth of Upper Three Runs. About 80 percent of this potential dose was from cesium-137.

\section{Savannah River Swamp Fisherman Soil Exposure} Pathway The potential dose to a recreational fisherman exposed to SRS legacy contamination in Savannah River Swamp soil on the privately owned Creek Plantation in 2007 was estimated using the RESRAD code [Yu et al., 2001]. It was assumed that this recreational sportsman fished on the South Carolina bank of the Savannah River near the mouth of Steel Creek for 250 hours during the year.

Using the radionuclide concentrations measured at this location, the potential dose to a fisherman from a combination of (1) external exposure to the contaminated soil, (2) incidental ingestion of the soil, and (3) incidental inhalation of resuspended soil was estimated to be $0.28 \mathrm{mrem}(0.0028 \mathrm{mSv})$.

As shown in table 6-4, the maximum Steel Creekmouth fish consumption dose (0.09 mrem) and the Savannah River Swamp fisherman soil exposure pathway were conservatively added together to obtain a total offsite creek-mouth fisherman dose of $0.37 \mathrm{mrem}(0.0037 \mathrm{mSv})$. This potential dose is 0.37 percent of the DOE 100 -mrem all-pathway dose standard.

\section{Potential Risk from Consumption of SRS Creek-Mouth Fish}

During 1991 and 1992, in response to a U.S. House of Representatives Appropriations Committee request for a plan to evaluate risk to the public from fish collected from the Savannah River, SRS developed-in conjunction with EPA, the Georgia 


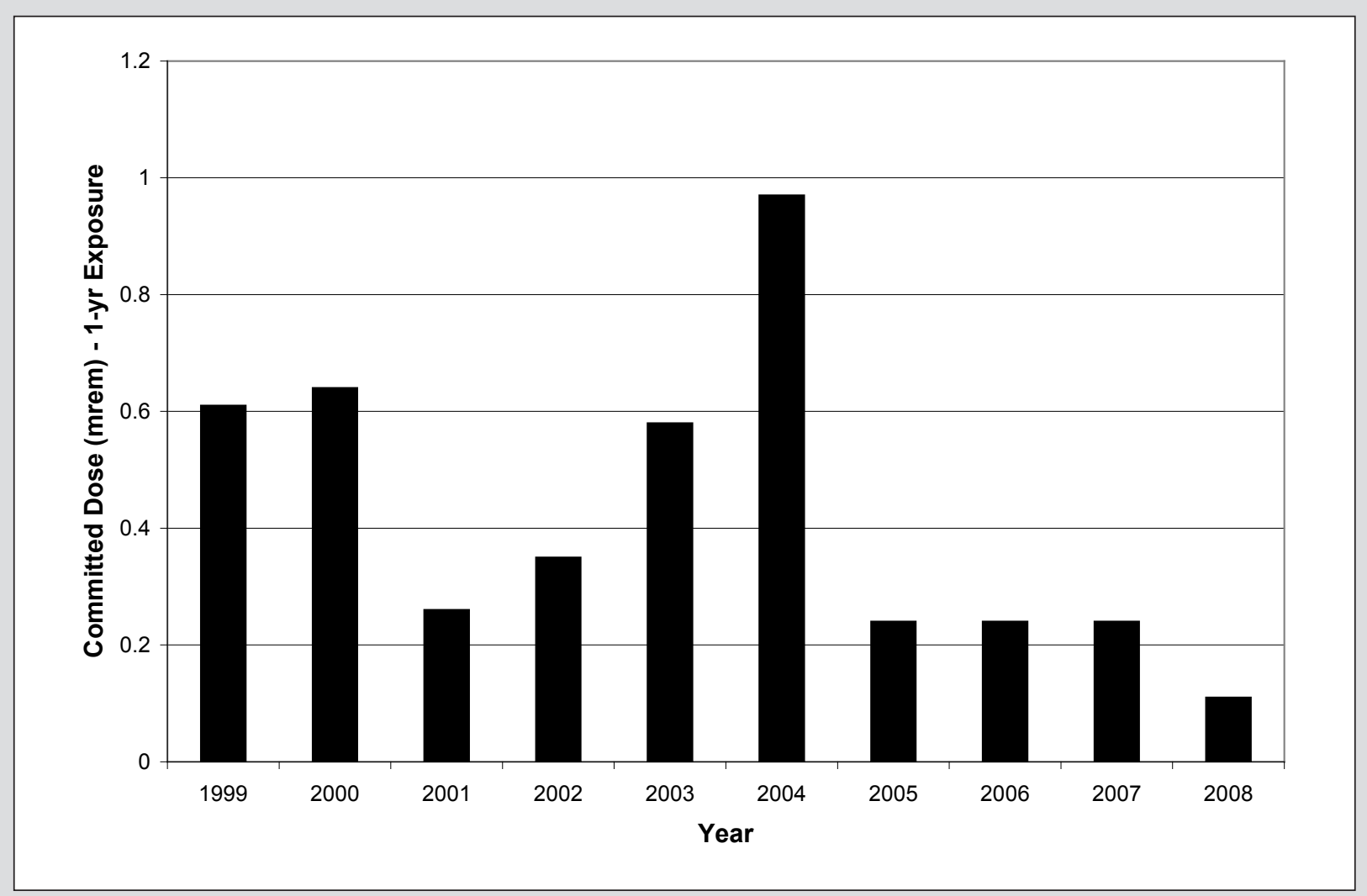

Figure 6-2 Ten-Year History of SRS Creek-Mouth Fisherman's Doses

Department of Natural Resources, and the South Carolina Department of Health and Environmental Control-the Westinghouse Savannah River Company/Environmental Monitoring Section Fish Monitoring Plan, which is summarized in SRS EM Program, 2002. Among the reporting requirements of this plan are (1) assessing radiological risk from the consumption of Savannah River fish and (2) presenting a summary of the results in the annual $S R S$ Environmental Report.

Risk Comparisons For 2008, the maximum potential radiation doses and lifetime risks from the consumption of SRS creek-mouth fish for 1-year, 30-year, and 50-year exposure durations are shown in table 6-5, and are compared to the radiation risks associated with the DOE Order 5400.5 all-pathway dose standard of $100 \mathrm{mrem}(1.0 \mathrm{mSv})$ per year. The potential risks were estimated using the cancer morbidity risk coefficients from Federal Guidance Report No. 13 [EPA, 1999].

For 2008, the maximum recreational fisherman dose was caused by the consumption of catfish collected at the mouth of Upper Three Runs. Figure 6-2 shows a 10 -year history of the annual potential radiation doses from consumption of Savannah River fish. No apparent trends can be discerned from these data. This is because of large variability in the cesium-137 concentrations measured in fish from the same location due to differences in

- the size of the fish collected each year

- their mobility and location within the stream mouth from which they are collected

- the time of year they are collected

- the amount of cesium-137 (and other radionuclides) available in the water and sediments at the SRS stream mouths - caused by annual changes in stream flow rates (turbulence) and water chemistry

As indicated in table 6-5, the 50-year maximum po- 
Table 6-5

Potential Lifetime Risks from the Consumption of Savannah River Fish Compared to Dose Standards

Committed Dose

(mrem)

\section{Savannah River Fish}

1-Year Exposure

5.50

Potential Risk ${ }^{\mathrm{a}}$

30-Year Exposure

50-Year Exposure

Dose Standard

100-Mrem/Year All Pathway

1-Year Exposure

100

30-Year Exposure

3,000

50-Year Exposure
5,000
8.2E-08

2.5E-06

4.1E-06

a It should be noted that all radiological risk factors are based on observed and documented health effects to actual people who have received high doses (more than 10,000 mrem) of radiation, such as the Japanese atomic bomb survivors. Radiological risks at low doses (less than 10,000 mrem) are theoretical and are estimated by extrapolating the observed health effects at high doses to the low-dose region by using a linear, no-threshold model. However, cancer and other health effects have not been observed consistently at low radiation doses because the health risks either do not exist or are so low that they are undetectable by current scientific methods.

tential lifetime risk from consumption of SRS creekmouth fish was 4.1E-06, which is below the 50-year risk (3.7E-03) associated with the 100-mrem-per-year dose standard.

If a potential lifetime risk is calculated to be less than 1.0E-06 (i.e., one additional case of cancer over what would be expected in a group of $1,000,000$ people), then the risk is considered minimal and the corresponding contaminant concentrations are considered negligible. If a calculated risk is more than 1.0E-04 (one additional case of cancer in a population of 10,000), then some form of corrective action or remediation usually is required. However, if a calculated risk falls between 1.0E-04 and 1.0E06 , which is the case with the maximum potential lifetime risks from the consumption of Savannah River fish, then the risk may be deemed acceptable if it is kept as low as reasonably achievable (ALARA), although actions to further reduce this risk can be considered. At SRS, the environmental ALARA program [SRS EM Program, 2002] is in place to ensure that the potential risk from site radioactive liquid effluents (and, therefore, from consumption of Savannah River fish) is kept ALARA.

\section{Radiation Dose to Aquatic and Terrestrial Biota}

DOE Order 5400.5 establishes an interim dose standard for protection of native aquatic animals. The absorbed dose limit to these organisms is $1.0 \mathrm{rad}$ per day (0.01 Gy per day) from exposure to radioactive material in liquid effluents released to natural waterways.

\section{DOE Biota Concentration Guides}

At SRS, the evaluations of biota doses for aquatic and terrestrial systems are performed using the RESRAD-Biota model (version 1.21), which is based 
on the DOE standard entitled A Graded Approach for Evaluating Radiation Doses to Aquatic and Terrestrial Biota [DOE, 2002].

The aquatic-systems evaluation includes exposures to primary (herbivores) and secondary (predators) aquatic animals, and the biota concentration guides (BCGs) are based on the 1.0-rad-per-day dose limit. Aquatic plants are not considered. The terrestrialsystems evaluation includes exposures to terrestrial plants and animals, and is based on a 10-rad-per-day dose limit for plants and a 0.1-rad-per-day dose limit for animals.

For the aquatic-systems evaluation, initial screenings were performed in 2008 using maximum radionuclide concentration data from the 10 SRS Environmental Monitoring Services (EMS) stream sampling locations from which co-located water and sediment samples are collected. An exception to this was made for sample location FM-2B (located on Four Mile Creek between F-Area and H-Area) because of its historically high cesium and tritium concentration levels. This location was included in the initial screening even though no co-located sediment sample is collected there. The combined water-plussediment BCG sum of the fractions was used for the aquatic systems evaluation. A sum of the fractions less than 1.0 indicates the sampling site has passed its initial pathway screening.

For the terrestrial-systems evaluation, initial screenings were performed using concentration data from the five EMS onsite radiological soil sampling locations. Only one soil sample per year is collected and analyzed for radioactivity from each location.

For 2008, all aquatic and terrestrial locations passed their initial pathway screenings. 

SRS operations have contaminated groundwater around certain waste disposal facilities. Extensive monitoring and remediation programs are tracking and cleaning up the contamination. Remediation includes (1) closing waste sites to reduce the migration of contaminants into groundwater and (2) actively treating contaminated water.

No offsite wells have been contaminated by the migration of SRS groundwater.

This chapter describes SRS's groundwater environment and the programs in place for investigating, monitoring, remediating, and using the groundwater.

\section{Groundwater at SRS}

SRS is underlain by sediment of the Atlantic Coastal Plain. The Atlantic Coastal Plain consists of a southeast-dipping wedge of unconsolidated sediment that extends from its contact with the Piedmont Province at the Fall Line to the edge of the continental shelf. The sediment ranges from Late Cretaceous to Miocene in age and comprises layers of sand, muddy sand, and clay with subordinate calcareous sediments. It rests on crystalline and sedimentary basement rock.

Water flows easily through the sandy layers (aquifers) but is retarded by less permeable clayey beds (confining units). Operations during the life of SRS have resulted in contamination migrating into groundwater at various site locations, predominantly in the central areas of the site. The ongoing movement of water into the ground, through the aquifer system, and then into streams and lakes - or even into deeper aquifers - continues to carry contamination along with it, resulting in spreading plumes.

The hydrostratigraphy of SRS has been subject to several classifications. The hydrostratigraphic classification established in Aadland et al., 1995, and in Smits et al., 1996, is used widely at SRS and is regarded as the current site standard. This system is consistent with the one used by the U.S. Geological Survey (USGS) in regional studies that include the area surrounding SRS [Clarke and West, 1998]. Figure 7-1 indicates the relative position of hydrostratigraphic units, and relates hydrostratigraphic units to corresponding lithologic units at SRS and to the geologic time scale. This chart was modified from Aadland et al., 1995, and Fallaw and Price, 1995.

The hydrostratigraphic units of primary interest beneath SRS are part of the Southeastern Coastal Plain Hydrogeologic Province. Within this sequence of aquifers and confining units are two principal subcategories, the overlying Floridan Aquifer System and the underlying Dublin-Midville Aquifer System. These systems are separated from one another by the Meyers Branch Confining System. In turn, each of the systems is subdivided into two aquifers, which are separated by a confining unit.

In the central to southern portion of SRS, the Floridan Aquifer System is divided into the overlying Upper Three Runs Aquifer and the underlying Gordon Aquifer, which are separated by the Gordon Confining Unit. North of Upper Three 


\section{7 - Groundwater}

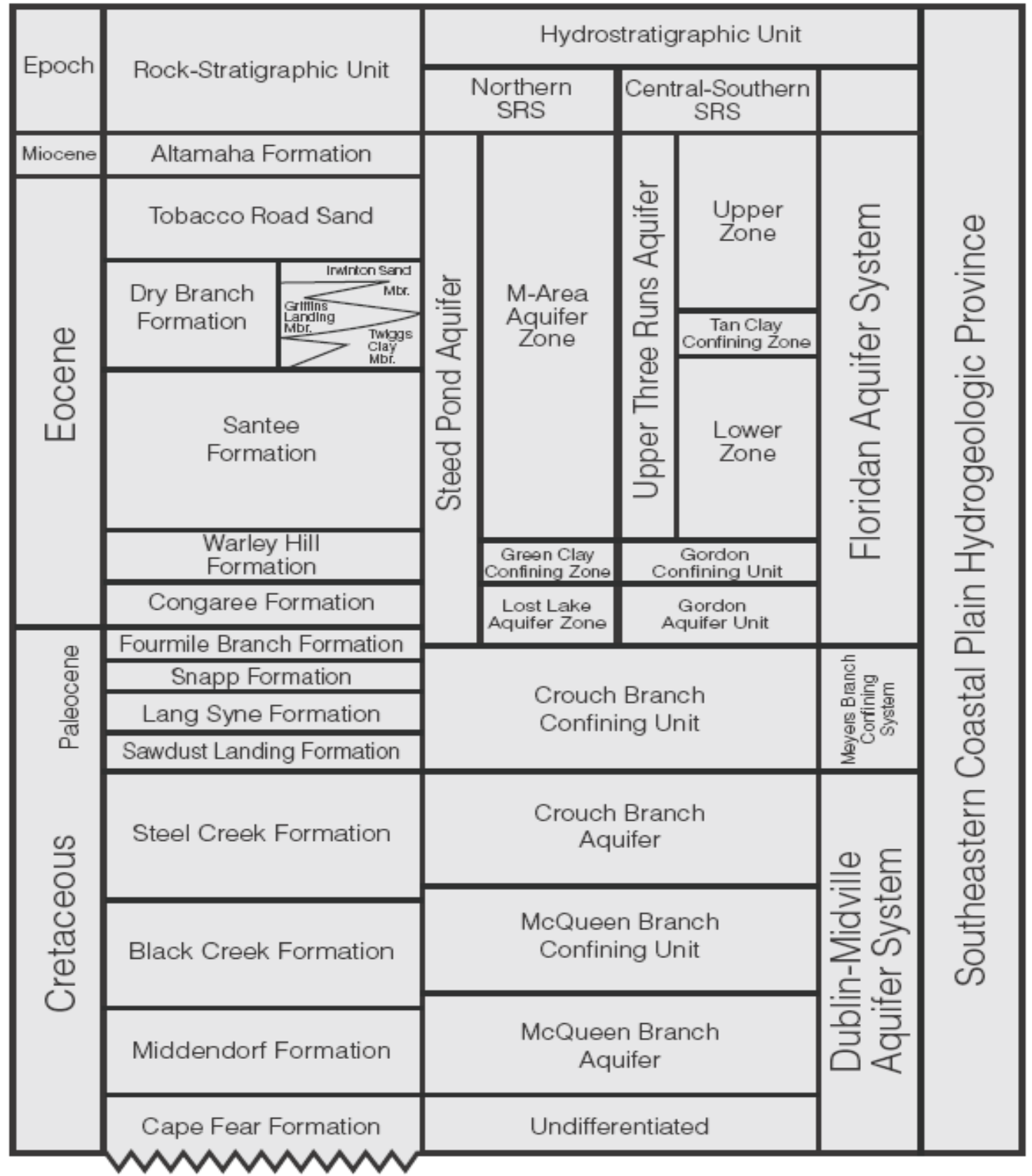

Paleozoic Crystalline

Basement Rock or Triassic

Piedmont Hydrogeologic Province

Newark Supergroup

Modified from Aadland et al., 1995, and Fallaw and Price, 1995

Figure 7-1 Hydrostratigraphic Units at SRS 
Runs Creek, these units are collectively referred to as the Steed Pond Aquifer, in which the Upper Three Runs Aquifer is called the M-Area Aquifer zone, the Gordon Aquifer is referred to as the Lost Lake Aquifer zone, and the aquitard that separates them is referred to as the Green Clay confining zone unit within which the water table usually occurs at SRS; hence, it is referred to informally as the "water table" aquifer. The water table surface can be as deep as 160 feet below ground surface (bgs), but intersects the ground surface in seeps along site streams. The top of the Gordon Aquifer typically is encountered at depths of 150-250 feet bgs. The Dublin-Midville Aquifer System is divided into the overlying Crouch Branch Aquifer and the underlying McQueen Branch Aquifer, which are separated by the McQueen Branch Confining Unit. The Crouch Branch Aquifer and McQueen Branch Aquifer are names that originated at SRS [Aadland et al., 1995]. These units are equivalent to the Dublin Aquifer and the Midville Aquifer, which are names originating with the USGS [Clarke and West, 1998]. The top of the Crouch Branch Aquifer typically is encountered at depths of 350-500 feet bgs. The top of the McQueen's Branch Aquifer typically is encountered at depths of 650-750 feet bgs.

Figure 7-2 is a three-dimensional block diagram of the hydrogeologic units at SRS and the generalized groundwater flow patterns within those units. These units are from shallowest to deepest: the Upper Three Runs/Steed Pond Aquifer (or water table aquifer), the Gordon/Lost Lake Aquifer, the Crouch Branch Aquifer, and the McQueen Branch Aquifer. Maps of the potentiometric surfaces of these units are presented in figures 18-21 of the "SRS Maps" ap-

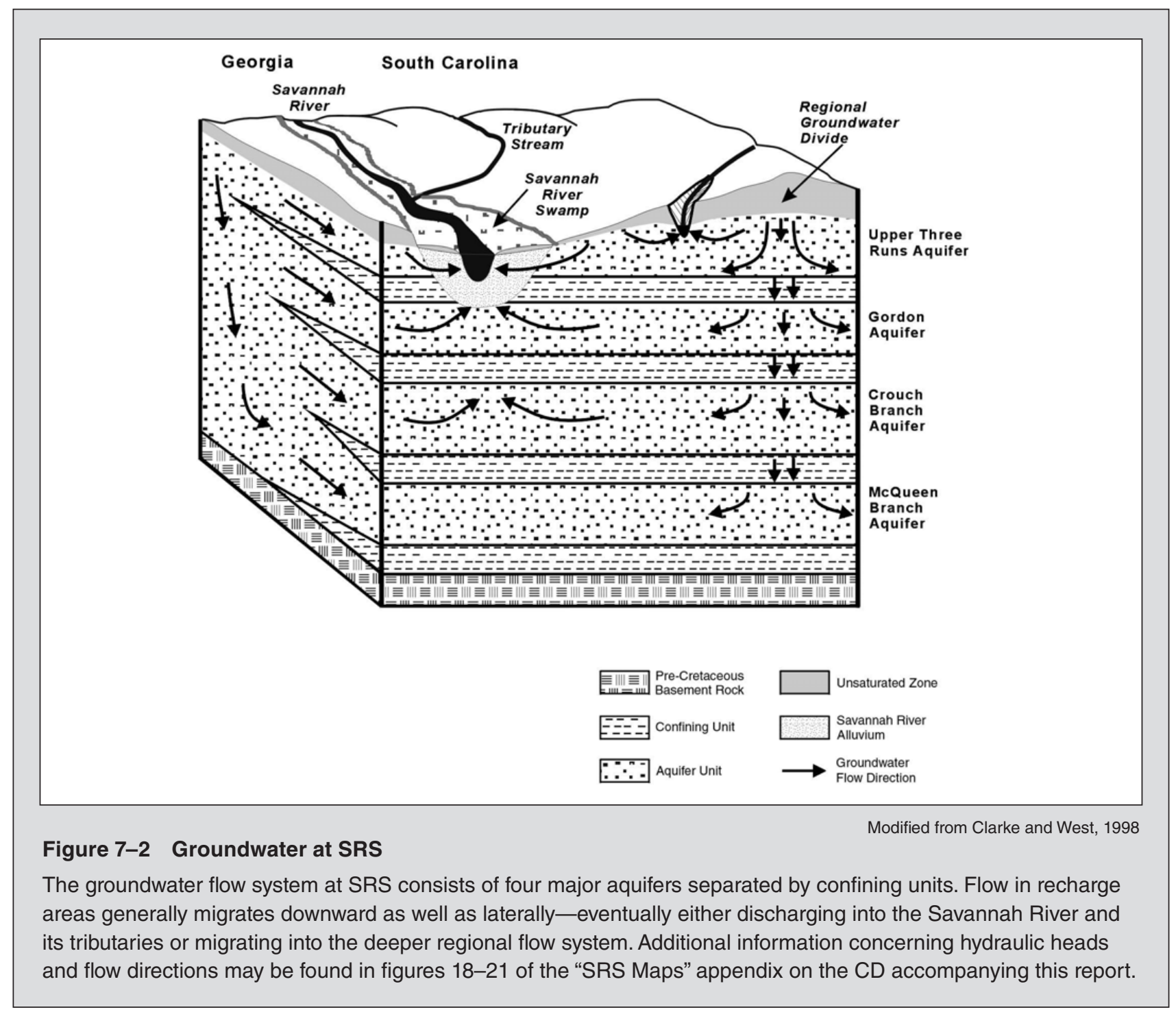


pendix on the $\mathrm{CD}$ accompanying this report.

Groundwater recharge is a result of the infiltration of precipitation at the land surface; the precipitation moves vertically downward through the unsaturated zone to the water table. Upon entering the saturated zone at the water table, water moves predominantly in a horizontal direction toward local discharge zones along the headwaters and midsections of streams, while some of the water moves into successively deeper aquifers. The water lost to successively deeper aquifers also migrates laterally within those units toward the more distant regional discharge zones. These typically are located along major streams, such as Upper Three Runs or Fourmile Branch, or along the Savannah River itself. Groundwater movement within these units is extremely slow when compared to surface water flow rates. Groundwater velocities also are quite different between aquitards and aquifers, ranging at SRS from several inches to several feet per year in aquitards and from tens to hundreds of feet per year in aquifers.

Monitoring wells are used extensively at SRS to assess the effects of site activities on groundwater quality. Most of the wells monitor the upper groundwater zone, although wells in lower zones are present at the sites with the larger groundwater contamination plumes. Groundwater in some areas contains one or more constituents at or above the levels of the drinking water standards of the U.S. Environmental Protection Agency (EPA). These areas can be seen in figure 17 of the "SRS Maps" appendix on the CD accompanying this report.

\section{Groundwater Protection Program at SRS}

The SRS groundwater program was audited by both the U.S. Department of Energy (DOE) and Washington (then Westinghouse) Savannah River Company (WSRC) in 2000 and 2001. Findings of these assessments have resulted in an ongoing evaluation of the site groundwater program's goals and priorities. It has been determined that a groundwater protection program designed to meet federal and state laws/regulations, DOE orders, and site policies/procedures should contain the following elements:

- investigating site groundwater

- using site groundwater
- protecting site groundwater

- remediating contaminated site groundwater

- monitoring site groundwater

SRS identified specific program goals in each of these areas to maintain its commitment to a groundwater program that protects human health and the environment. Groundwater monitoring is a key tool used in each of the first four elements, and monitoring results form the basis for evaluations that are reported to site stakeholders.

\section{Investigating SRS Groundwater}

An extensive program is in place at SRS to acquire new data and information on the groundwater system. This multifaceted program is conducted across departmental boundaries at the site because of the different charters and mandates of these organizations. Investigations include both the collection and analysis of data to understand groundwater conditions on regional and local scales at SRS. Research efforts at the site generally are conducted to obtain a better understanding of subsurface processes and mechanisms or to define new approaches to subsurface remediation.

Investigative efforts focus on the collection and analysis of data to characterize the groundwater flow system. Characterization efforts at SRS include the following activities:

- collection of geologic core material and performance of seismic profiles to better delineate subsurface structural features

- installation of wells to allow periodic collection of both water levels and groundwater samples at strategic locations

- development of water table and potentiometric maps to delineate the direction of groundwater movement in the subsurface

- performance of various types of tests to obtain in situ estimates of hydraulic parameters needed to estimate groundwater velocities

Analysis of data on the regional scale is needed to provide a broad understanding of groundwater movement patterns at SRS that can be used as a 
framework to better understand the migration of contaminants at the local scale near individual waste units.

Surface water flow characteristics also are defined at the SRS on the regional scale and are significant to risk analyses because perennial streams are the receptors of groundwater discharge - some of which contains contaminants from SRS waste units. Because the site boundary does not represent a groundwater boundary, regional studies are helpful in understanding the movement of groundwater both onto the site from the surrounding area and vice versa.

The collection and analysis of data describing subsurface hydrogeologic conditions at or near individual waste units are needed to design effective remediation systems. Characterization embraces both traditional and innovative technologies to accomplish this goal. The installation of monitoring wells and piezometers is a traditional investigative method to allow the collection of (1) water levels, which are used to define flow directions, and (2) groundwater samples, which are analyzed to monitor contaminant plume migration within the groundwater flow system. Geophysical data acquired during well installation are used to delineate the subsurface hydrostratigraphy. Examples of newer technologies include the use of

- direct-push technology, such as the cone penetrometer, to collect one-time groundwater samples at investigation sites and to help establish hydrostratigraphic contacts

- the "rotosonic" method for bore holes to collect cores and install wells

- borehole flow-meters to measure ambient flow and hydraulic conductivity distributions along wells.

Models have been used extensively as analytical tools at SRS for both regional and local investigations. Models have been utilized for a variety of reasons, but primarily to (1) define the regional groundwater movement patterns at SRS and the surrounding areas, (2) enhance the understanding of contaminant migration in the subsurface, and (3) support the design of remediation systems. At SRS, major groundwater modeling efforts have focused on A/M-Area, F-Area, H-Area, the Burial Ground Complex, and several of the reactor areas where the most extensive subsurface contamination is known to exist.

Research on groundwater issues is conducted at SRS to obtain a better understanding of subsurface mechanisms, such as (1) the interaction of contaminants with the porous media matrix and (2) the factors that impact the rate of migration of contaminants within the groundwater flow system. Research to address relevant issues often is conducted through cooperative studies with investigators at various public universities and private companies, while other efforts are conducted exclusively by SRS employees.

\section{Using SRS Groundwater}

SRS derives its own drinking and process water supply from groundwater. SRS domestic and process water systems are supplied from a network of approximately 40 wells in widely scattered locations across the site, of which eight supply the primary drinking water system for the site (figure 13 in the "SRS Maps" appendix on the CD accompanying this report). In 1983, SRS began reporting its water usage annually to the South Carolina Water Resources Commission - and later to the South Carolina Department of Health and Environmental Control (SCDHEC). Since that time, the amount of groundwater pumped on site has dropped by more than two thirds - from 10.8 million gallons per day during 1983-1986 to 2.7 million gallons per day in 2008. The majority of this decrease is attributable to the consolidation of site domestic water systems, which was completed in 1997. Thirteen separate systems, each with its own high-capacity supply wells, were consolidated into three systems located in A-Area, D-Area, and K-Area. This greatly reduced the amount of excess water being pumped to waste. Site facility shutdowns and reductions in population also were contributing factors.

Treated well water is supplied to the larger site facilities by the A-Area, D-Area, and K-Area domestic water systems. Each system has wells, a treatment plant, elevated storage tanks, and distribution piping. The wells range in capacity from 200 to 1,500 gallons per minute. The A-Area, D-Area, and K-Area systems supply an average of 1 million gallons per day of domestic water to customers in these areas. The domestic water systems supply site drinking fountains, lunchrooms, restrooms, and showering facilities with water meeting state and federal drinking water quality standards. SCDHEC 
periodically samples the large- and small-system wells for Safe Drinking Water Act contaminants. An unscheduled biannual SCDHEC sanitary survey also is performed.

The process water systems in A-Area, F-Area, H-Area, K-Area, L-Area, S-Area, and TNX-Area meet site demands for boiler feedwater, equipment cooling water, facility washdown water, and makeup water for cooling towers, fire storage tanks, chilledwater-piping loops, and site test facilities. These systems are supplied from dedicated process water wells ranging in capacity from 100 to 1,500 gallons per minute. In K-Area, the process water system is supplied from the domestic water wells. At some locations, the process water wells pump to groundlevel storage tanks, where the water is treated for corrosion control. At other locations, the wells directly pressurize the process water distribution piping system without supplemental treatment.

The site groundwater protection program integrates information learned about the properties of SRS aquifers with site demand for drinking and process water. SRS ensures a high level of drinking water supply protection by (1) monitoring above and beyond SCDHEC requirements and (2) periodically evaluating production wells.

Virtually all site process and drinking water is pumped from the Crouch Branch and McQueen's Branch Aquifers. The amount of groundwater pumped at SRS has had only localized effects on water levels in these aquifers, and it is unlikely that water usage at the site ever will cause drawdown problems that could impact surrounding communities.

\section{Protecting SRS Groundwater}

SRS is committed to protecting the groundwater resource beneath the site. A variety of activities contribute to this goal, including

- construction, waste management, and monitoring efforts to prevent or control sources of groundwater contamination

- monitoring programs (both groundwater and surface water) to detect contamination

- a strong groundwater cleanup program through the site's Area Completion Projects (ACP) organization
Monitoring around known waste disposal sites and operating facilities provides the best means to detect and track groundwater contamination. To detect contamination from as-yet undiscovered sites, SRS depends on a sitewide groundwater monitoring and protection effort - the site Groundwater Surveillance Monitoring Program (GSMP). This program is an upgraded replacement of the site screening program.

Monitoring wells and production wells are properly abandoned when no longer needed. A typical abandonment involves placing a smaller diameter pipe ("tremie pipe") near the bottom of the well and pumping cement grout through it until the well is full. This ensures that grout reaches the bottom of the well. SRS abandoned 110 monitoring wells in 2008; additional abandonments are planned for 2009.

One goal of the GSMP is to protect potential offsite receptors from contamination by detecting the contamination in time to apply appropriate corrective actions. SRS is a large site, and most groundwater contamination is located in its central areas. However, the potential for offsite migration exists, and the consequences of such an outcome are serious enough to warrant a comprehensive prevention program.

SRS has evaluated flow in each aquifer and determined where there is potential for flow across the site boundary. This gives a conservative indication of where offsite contamination might be possible, and allows for a focused monitoring effort in those few areas. Another pathway for existing groundwater contamination to flow off site is by discharge into surface streams and subsequent transport into the Savannah River. SRS monitors site streams for contamination, and has installed wells along several site streams to (1) detect contamination before it enters the streams and (2) assess the contamination's concentration in groundwater.

The SRS groundwater monitoring program gathers information to determine the effects of site operations on groundwater quality. The program is designed to

- assist the site in complying with environmental regulations and DOE directives

- $\quad$ provide data to identify and monitor constituents in the groundwater

- provide data for evaluating new facility locations to ensure suitablity for the intended facilities 


\section{Sample Scheduling and Collection}

The Geochemical Monitoring group and the Environmental Protection Section schedule groundwater sampling either in response to specific requests from SRS personnel or as part of their ongoing groundwater monitoring program. Approximately 1,100 wells and numerous direct-push holes are sampled each year. Most of the wells are sampled semiannually, but many are sampled only annually. These groundwater samples provide data for reports required by federal and state regulations and for internal reports and research projects. The data are presented in spreadsheets on the attached CD, and fill approximately 170,000 lines.

Constituents that may be analyzed are commonly imposed by permit or work plan approval. These include metals, field parameters, and suites of herbicides, pesticides, volatile organics, and others. Radioactive constituents that may be analyzed by request include gross alpha and beta measurements, gamma emitters, iodine-129, strontium-90, radium isotopes, uranium isotopes, and other alpha and beta emitters.

Groundwater samples are collected from monitoring wells, generally with either pumps or bailers dedicated to each well to prevent cross-contamination among wells. Occasionally, portable sampling equipment is used; this equipment is decontaminated between wells.

Sampling and shipping equipment and procedures are consistent with EPA, SCDHEC, and U.S. Department of Transportation guidelines. EPA-recommended preservatives and sample-handling techniques are used during sample storage and transportation to both onsite and offsite analytical laboratories. Potentially radioactive samples are screened for total activity prior to shipment to determine appropriate packaging and labeling requirements.

Deviations from scheduled sampling and analysis for 2008 (caused by dry wells, inoperative pumps, etc.) were entered into the site's groundwater database and issued in appropriate reports.

- $\quad$ support basic and applied research projects

The groundwater monitoring program at SRS includes two primary components: (1) waste site monitoring associated with remediation, overseen by the Geochemical Monitoring group of ACP, and (2) groundwater surveillance monitoring, conducted by the Environmental Protection Section. To assist other departments in meeting their responsibilities, personnel of both organizations provide the services for installing monitoring wells, collecting and analyzing samples, and reporting results.

Monitoring data are evaluated each year to identify unexpected results in any SRS wells that might indicate new or changing groundwater contamination.

\section{Remediating Contaminated SRS Groundwater}

SRS has maintained an environmental remediation effort for many years. ACP personnel manage the cleanup of contaminated groundwater associated with Resource Conservation and Recovery Act (RCRA) hazardous waste management facilities and other non-RCRA contamination sites specified in SRS's Federal Facility Agreement. Their mission is to aggressively manage the inactive waste site and groundwater cleanup program so that

- $\quad$ schedules for environmental agreements are consistently met

- the utilization of financial and technological resources is continually improved

- the overall risk posed by existing contaminated sites is continually reduced

The ACP strategy revolves around developing an appropriate regulatory framework for each waste site, assessing the degree and extent of contamination, and remediating the contaminated groundwater to its original beneficial use. Remedial technologies being used include pump and treat, in situ $\mathrm{pH}$ adjustment, steam injection, phytoremediation, and barrier wall construction. In cases where remediation to background quality is impractical, the intent is to prevent plume migration and exposure and to evaluate alternate methods of risk reduction.

\section{Monitoring SRS Groundwater}

The first priority of the groundwater monitoring program at SRS is to ensure that contamination is 
not being transported from the site by groundwater flow. Contaminated groundwater at SRS discharges into site streams or the Savannah River. Nowhere have offsite wells been contaminated by groundwater from SRS, and only a few site locations have groundwater with even a remote chance of contaminating such wells.

One of these locations is near A-Area/M-Area, the site of a large chlorinated solvent plume. This area's groundwater monitoring program uses more than 200 wells, and some of the contaminated wells lie within a half-mile of the site's northeastern boundary. While it is believed that the major component of groundwater flow is not directly toward the site boundary, flow in the area is complex and difficult to predict. For this reason, particular attention is paid to data from wells along the site boundary and from those between A-Area/M-Area and the nearest population center, Jackson, South Carolina (figure 22 in the "SRS Maps" appendix on the CD accompanying this report). During 2008, the wells at the JAX-1, JAX-2 and MSB-84 clusters were free of chlorinated solvents. Three of the JAX wells did show trace amounts of methylene chloride and acetone, and one well, JAX-2LCB, contained trace amounts of toluene.

Since the early 1990s, considerable effort has been directed at assessing the likelihood of transriver flow from South Carolina to Georgia, and 44 wells have been drilled by the USGS and the Georgia Department of Natural Resources (figure 23 in the "SRS Maps" appendix on the CD accompanying this report). Despite the fact that the USGS groundwater model indicates there is no mechanism by which transriver flow could contaminate Georgia wells [Cherry, 2006], SRS continues to maintain and sample the Georgia monitoring wells annually. In 2008, none of the tritium results exceeded 1,000 $\mathrm{pCi} / \mathrm{L}$. Levels this low are consistent with aquifer recharge from rainfall. EPA's maximum contaminant level for tritium is $20,000 \mathrm{pCi} / \mathrm{L}$.

Although contaminated groundwater in most SRS areas does not approach the site boundary, it does have the potential to impact site streams. For this reason - and because of the need to meet the requirements of various environmental regulations- extensive monitoring is conducted around SRS waste sites and operating facilities, regardless of their proximity to the boundary.

Table 7-1 presents a general summary of the most contaminated groundwater conditions at SRS, based on 2007 and 2008 monitoring data. The table shows the 2008 maximum concentrations for major constituents in SRS areas that have contaminated groundwater-and how these concentrations compare to the drinking water standards and the 2006 maximums. As shown in the table, the two major contaminants of concern in groundwater are (1) common degreasers (trichloroethylene and perchloroethylene) and (2) radionuclides (tritium and gross alpha and nonvolatile beta emitters).

Table 7-1 also shows where the contaminated water most likely will outcrop. By the time the groundwater reaches a stream, it generally is much less contaminated because of natural attenuation processes such as dilution and biodegradation. As indicated above, results in the table are maximum values generally associated with wells very close to contaminant source areas, where little attenuation has taken place.

All groundwater monitoring data for 2008 are included in the "2008 Groundwater Data" table on the $\mathrm{CD}$ accompanying this report. It would be impractical to provide maps of all wells; however, Universal Transverse Mercator (UTM) coordinates are provided. These coordinates can be used in conjunction with figure 24 in the "SRS Maps" appendix on the $\mathrm{CD}$ to find the approximate locations of the wells.

Contaminant plumes of particular interest are depicted in a series of maps in the "SRS Maps" appendix on the CD. Figures 25-30 depict the trichloroethylene plumes in aquifers beneath $\mathrm{A}$ and M Areas. Figures 31-33 depict the tritium plumes in aquifers beneath E, F, and $\mathrm{H}$ Areas. For details about monitoring and conditions at individual sites, one should refer to site-specific documents, such as RCRA corrective action reports or RCRA/Comprehensive Environmental Response, Compensation, and Liability Act and RCRA facility investigation/ remedial investigation reports. 
Table 7-1

Summary of Maximum Well Monitoring Results for Major Areas Within SRS, 2007-2008

\begin{tabular}{|c|c|c|c|c|c|c|}
\hline Location & $\begin{array}{l}\text { Major } \\
\text { Contaminants }\end{array}$ & Units & $\begin{array}{l}2007 \\
\text { Max (near } \\
\text { source) }\end{array}$ & MCL & $\begin{array}{l}2008 \\
\text { Max (near } \\
\text { source) }\end{array}$ & $\begin{array}{l}\text { Likely Discharge } \\
\text { Point After } \\
\text { Transport and Attenuation }\end{array}$ \\
\hline $\begin{array}{l}\text { A-Area/ } \\
\text { M-Area }\end{array}$ & $\begin{array}{l}\text { TCE } \\
\text { PCE }\end{array}$ & $\begin{array}{l}\mathrm{ppb} \\
\mathrm{ppb}\end{array}$ & $\begin{array}{l}34,000 \\
85,500\end{array}$ & $\begin{array}{l}5 \\
5\end{array}$ & $\begin{array}{l}59,600 \\
128,000\end{array}$ & $\begin{array}{l}\text { Tims Branch/Upper Three } \\
\text { Runs Creek in Swamp in West }\end{array}$ \\
\hline C-Area & $\begin{array}{l}\text { TCE } \\
\text { Tritium }\end{array}$ & $\begin{array}{l}\mathrm{ppb} \\
\mathrm{pCi} / \mathrm{L}\end{array}$ & $\begin{array}{l}4,970 \\
1,190,000\end{array}$ & $\begin{array}{l}5 \\
50,000\end{array}$ & $\begin{array}{l}5,200 \\
2,550,000\end{array}$ & Tributaries of Fourmile Branch \\
\hline D-Area & $\begin{array}{l}\text { TCE } \\
\text { Tritium }\end{array}$ & $\begin{array}{l}\mathrm{ppb} \\
\mathrm{pCi} / \mathrm{L}\end{array}$ & $\begin{array}{l}120 \\
545,000\end{array}$ & $\begin{array}{l}5 \\
20,000\end{array}$ & $\begin{array}{l}300 \\
392,000\end{array}$ & Savannah River Swamp \\
\hline E-Area & $\begin{array}{l}\text { Tritium } \\
\text { TCE }\end{array}$ & $\begin{array}{l}\mathrm{pCi} / \mathrm{L} \\
\mathrm{PPB}\end{array}$ & $\begin{array}{l}30,800,00 \\
370\end{array}$ & $\begin{array}{l}20,000 \\
5\end{array}$ & $\begin{array}{l}29,200,000 \\
460\end{array}$ & $\begin{array}{l}\text { Upper Three Runs/ } \\
\text { Crouch Branch in North; } \\
\text { Fourmile Branch in South }\end{array}$ \\
\hline F-Area & $\begin{array}{l}\text { TCE } \\
\text { Tritium } \\
\text { Gross alpha } \\
\text { Beta }^{\text {b }}\end{array}$ & $\begin{array}{l}\mathrm{ppb} \\
\mathrm{pCi} / \mathrm{L} \\
\mathrm{pCi} / \mathrm{L} \\
\mathrm{pCi} / \mathrm{L}\end{array}$ & $\begin{array}{l}52.2 \\
73,000 \\
2,120 \\
380\end{array}$ & $\begin{array}{l}5 \\
20,000 \\
15 \\
4 \mathrm{mrem} / \mathrm{yr}^{\mathrm{a}}\end{array}$ & $\begin{array}{l}60 \\
130,000 \\
1,470 \\
628\end{array}$ & $\begin{array}{l}\text { Upper Three Runs/ } \\
\text { Crouch Branch in North } \\
\text { Fourmile Branch in South }\end{array}$ \\
\hline $\begin{array}{l}\text { F-Area } \\
\text { Seepage } \\
\text { Basin }\end{array}$ & $\begin{array}{l}\text { Tritium } \\
\text { Gross alpha } \\
\text { Beta }^{\text {b }}\end{array}$ & $\begin{array}{l}\mathrm{pCi} / \mathrm{L} \\
\mathrm{pCi} / \mathrm{L} \\
\mathrm{pCi} / \mathrm{L}\end{array}$ & $\begin{array}{l}5,710,000 \\
523 \\
1,870\end{array}$ & $\begin{array}{l}20,000 \\
15 \\
4 \mathrm{mrem} / \mathrm{yr}^{\mathrm{a}}\end{array}$ & $\begin{array}{l}4,810,000 \\
777 \\
2,100\end{array}$ & Fourmile Branch \\
\hline H-Area & $\begin{array}{l}\text { Tritium } \\
\text { Gross alpha } \\
\text { Beta }^{\text {b }}\end{array}$ & $\begin{array}{l}\mathrm{pCi} / \mathrm{L} \\
\mathrm{pCi} / \mathrm{L} \\
\mathrm{pCi} / \mathrm{L}\end{array}$ & $\begin{array}{l}67,200 \\
25.5 \\
55.6\end{array}$ & $\begin{array}{l}20,000 \\
15 \\
4 \mathrm{mrem} / \mathrm{yr}^{\mathrm{a}}\end{array}$ & $\begin{array}{l}74,800 \\
14.9 \\
81.9\end{array}$ & $\begin{array}{l}\text { Upper Three Runs/ } \\
\text { Crouch Branch in North; } \\
\text { Fourmile Branch in South }\end{array}$ \\
\hline $\begin{array}{l}\text { H-Area } \\
\text { Seepage } \\
\text { Basins }\end{array}$ & $\begin{array}{l}\text { Tritium } \\
\text { Gross alpha } \\
\text { Beta }^{\text {b }}\end{array}$ & $\begin{array}{l}\mathrm{pCi} / \mathrm{L} \\
\mathrm{pCi} / \mathrm{L} \\
\mathrm{pCi} / \mathrm{L}\end{array}$ & $\begin{array}{l}3,020,000 \\
88.4 \\
2,970\end{array}$ & $\begin{array}{l}20,000 \\
15 \\
4 \mathrm{mrem} / \mathrm{yr}^{\mathrm{a}}\end{array}$ & $\begin{array}{l}3,120,000 \\
85 \\
2,050\end{array}$ & Fourmile Branch \\
\hline R-Area & $\begin{array}{l}\text { Tritium } \\
\text { Strontium-90 }\end{array}$ & $\begin{array}{l}\mathrm{pCi} / \mathrm{L} \\
\mathrm{pCi} / \mathrm{L}\end{array}$ & $\begin{array}{l}1,410,000 \\
464\end{array}$ & $\begin{array}{l}20,000 \\
8\end{array}$ & $\begin{array}{l}1,740,000 \\
155\end{array}$ & $\begin{array}{l}\text { Mill Creek in Northwest; } \\
\text { tributaries of PAR Pond elsewhere }\end{array}$ \\
\hline K-Area & $\begin{array}{l}\text { Tritium } \\
\text { TCE }\end{array}$ & $\begin{array}{l}\mathrm{pCi} / \mathrm{L} \\
\mathrm{ppb}\end{array}$ & $\begin{array}{l}179,000 \\
23.5\end{array}$ & $\begin{array}{l}20,000 \\
5\end{array}$ & $\begin{array}{l}937,000 \\
22\end{array}$ & Indian Graves Branch \\
\hline L-Area & Tritium & $\mathrm{pCi} / \mathrm{L}$ & $1,070,000$ & 20,000 & 852,000 & L Lake \\
\hline P-Area & Tritium & $\mathrm{pCi} / \mathrm{L}$ & 39,700 & 20,000 & 90,700 & $\begin{array}{l}\text { Steel Creek in North; } \\
\text { Meyer's Branch in South }\end{array}$ \\
\hline $\begin{array}{l}\text { Sanitary } \\
\text { Landfil }\end{array}$ & $\begin{array}{l}\text { TCE } \\
\text { Vinyl Chloride }\end{array}$ & $\begin{array}{l}\mathrm{ppb} \\
\mathrm{ppb}\end{array}$ & $\begin{array}{l}14 \\
150\end{array}$ & $\begin{array}{l}5 \\
2\end{array}$ & $\begin{array}{l}14 \\
120\end{array}$ & Upper Three Runs Creek \\
\hline TNX & TCE & $\mathrm{ppb}$ & 735 & 5 & 195 & Savannah River Swamp \\
\hline CMP Pits & TCE & $\mathrm{ppb}$ & 851 & 5 & 853 & Pen Branch \\
\hline
\end{tabular}



Quality Assurance

Jay Hutchison

Environmental \& Bioassay Laboratory, Environmental Monitoring Laboratory

Donald Padgett and Monte Steedley

Regulatory Integration \& Environmental Services

Wendy Cruz and Rick Page

Data Management \& Waste Engineering

[During 2008, responsibility for the environmental Quality Assurance (QA) program continued to be divided among three groups-Environmental Monitoring Laboratory (EML), Environmental Monitoring (EM), and Data Management and Waste Engineering (DMWE).]

Qs

$R S$ 's environmental $Q A$ program is conducted to verify the integrity of analyses determined by onsite

and subcontracted offsite environmental laboratories, and to ensure that quality control program

requirements are met. The program's objectives are to ensure that samples are representative of the surrounding environment, and that analytical results are accurate.

\section{SRS and Environmental QA Programs Integration}

The SRS comprehensive environmental QA program follows the QA requirements defined in the WSRC Quality Assurance Manual (WSRC 1Q). Each environmental organization has developed and implemented QA procedures that address these requirements. In addition, a Cognizant Quality Function (CQF) from the site's independent QA organization is assigned responsibility for environmental program oversight for each organization. The CQF periodically performs QA reviews and assessments on environmental programs to ensure compliance with site requirements. In addition, each organization assigns QA responsibilities to individuals to oversee daily QA activities for the organization. Results, improvement opportunities, and corrective actions that come from assessments and reviews are documented in the Site Tracking, Analysis and Reporting (STAR) system. Site environmental professionals periodically conduct QA self-assessments on specific environmental program activities. The results of these assessments are documented in STAR. Site management participates in the Management Field Observation process, and the results from these reviews also are documented in STAR.

\section{QA for EM Program Samples} Internal Quality Assurance Program

EM has a documented QA program that meets SRS and U.S. Department of Energy (DOE) requirements (3Q1-2 Volume III, "Quality Assurance Plan"). Based on data reviews, no QA issues or corrective actions were identified during 2008.

\section{Laboratory Certification}

EM is certified by the South Carolina Department of Health and Environmental Control (SCDHEC) Office of Laboratory Certification for field $\mathrm{pH}$ and total residual chlorine measurements. Certification is renewed every three years; the current certification expires in June of this year.

\section{Blind pH Samples}

EM personnel routinely conduct blind sample programs for field measurements of $\mathrm{pH}$ to assess the quality and reliability of field data measurements.

During 2008, two blind $\mathrm{pH}$ field measurements were taken monthly, for a total of 24 samples. All field $\mathrm{pH}$ 


\section{Quality Control Sample Definitions}

Blank - A sample that has not been exposed to the sample stream in order to monitor contamination during sampling, transport, storage, or analysis. The blank is subjected to the usual analytical and measurement process to establish a zero-baseline or -background value, and sometimes is used to adjust or correct routine analytical results.

Blind Sample - A subsample for analysis with a composition known to the submitter. The analyst/laboratory may know the identity of the sample, but not its composition. It is used to test the analyst's or laboratory's proficiency in the execution of the measurement process.

Carrier - A stable isotope of a radionuclide (usually the analyte) added to increase the total amount of that element so that a measurable mass of the element is present.

Cross-talk - The fraction of all recorded pulses from alpha particles that are recorded in the beta channel due to degradation in their pulse height or the fraction of all recorded pulses from beta particles that are recorded in the alpha channel due to pulse pileup or other phenomenon.

Field Duplicates - Independent samples collected as closely as possible to the same point in space and time. They are two separate samples taken from the same source, stored in separate containers, and analyzed independently.

Laboratory Control Sample (LCS) - A sample matrix, free from the analytes of interest, spiked with verified known amounts of analytes or a material containing known and verified amounts of analytes. It generally is used to establish intralaboratory or analyst-specific precision and bias, or to assess the performance of all or a portion of the measurement system.

Laboratory Duplicate - Aliquot of a sample taken from the same container under laboratory conditions and processed and analyzed independently.

Spike - A known mass of target analyte added to a blank sample (see LCS) or subsample (a matrix spike); used to determine recovery efficiency, or for other QC purposes.

Tracer - A radioactive isotope that chemically mimics and does not interfere with the target analyte through radiochemical separations. Isotopic tracers typically are radioactive materials (e.g., U-232, Pu-242). Tracers are added to samples to determine the overall chemical yield for the analytical preparation steps.

measurements were within the U.S. Environmental Protection Agency's (EPA's) suggested acceptable control limit of $\pm 0.4 \mathrm{pH}$ units of the true (known) value. Blind $\mathrm{pH}$ sample results can be found in the data tables section of the CD accompanying this report ["Blind Sample Results for $\mathrm{pH}$ Field Measurements"].

\section{QA for EML Sample Analyses}

\section{Internal QA Program}

EML has a documented QA program (Procedure Manual L3.25, "Environmental Monitoring Quality Assurance Procedures") that meets SRS and DOE requirements. Analytical instrumentation includes liquid scintillation and gas flow proportional counters, alpha and gamma spectrometry, inductively coupled plasma atomic emission spectrometry
(ICP-AES), inductively coupled plasma mass spectrometry (ICP-MS), flow injection mercury system (FIMS) and gas chromatography mass spectrometry (GC-MS). Analyses include tritium, carbon-14, nickel-63, gamma isotopes (cesium-137, cobalt-60, potassium-40, etc.), iodine-129, strontium 89,90, strontium-90, americium-241, curium-244, neptunium-237, plutonium-238, plutonium-239, thorium-229, thorium-230, thorium-232, uranium-234, uranium235, uranium-238, inorganic metals, mercury, and volatile organic compounds. Total suspended solids are determined gravimetrically. Instruments are calibrated with known reference standards. Instrument performance is monitored through the use of check standards and control charts. Analytical batch performance is measured through the use of quality control (QC) samples (blanks, spikes, carriers, tracers, laboratory control samples, and laboratory duplicates). QC results that fall outside of speci- 
fied limits may result in analytical batch or sample reruns. For those batches or samples that fall outside of limits but for which the results are determined to be satisfactory, the reason is documented in the data package, which includes the QA cover sheet, instrument data printouts, and associated QC data.

Based on inspections of instrument records and analytical data packages, no corrective actions were identified during 2008.

\section{Laboratory Certification}

EML is certified by the SCDHEC Office of Laboratory Certification for analytical measurements using the following methods:

- total suspended solids (Standard Methods, 2540D), 27 metals by ICP-AES (EPA, 200.7), mercury by FIMS (EPA, 245.2), and 18 metals by ICP-MS (EPA, 200.8)

- 42 volatile organic compounds by GC-MS (EPA, 8260B), 28 metals by ICP-AES (EPA, 6010C), mercury by FIMS (EPA, 7470A and 7471B), and 18 metals by ICP-MS (EPA, 6020A)
Certification is renewed every three years; the current certification expires in June 2009.

\section{External QA Program}

In 2008, EML participated in the DOE Mixed Analyte Performance Evaluation Program (MAPEP), an interlaboratory comparison program that tracks performance accuracy and tests the quality of environmental data reported to DOE. The Radiological and Environmental Sciences Laboratory (RESL), under the direction of DOE-Headquarters Environmental Safety and Health (ES\&H), administers the MAPEP.

MAPEP samples include water, soil, air filter, and vegetation matrices with environmentally important stable inorganic, organic, and radioactive constituents.

In 2008, EML completed the analysis of 54 radioisotopes and 15 metals for MAPEP-18 (designation of a specific study set) and the analysis of 56 radioisotopes and 15 metals for MAPEP-19. Results show that the laboratory passed the 80 -percent-acceptable-results level for the study set (table 8-1). The

Table 8-1

EML Performance on Mixed-Analyte Performance Evaluation Program (MAPEP)

\begin{tabular}{|c|c|c|}
\hline Study Set & Matrix & $\mathrm{EML}^{1}$ \\
\hline MAPEP-07-GrF18 & Air Filter & $100 \%$ \\
\hline MAPEP-07-GrW18 & Water & $100 \%$ \\
\hline MAPEP-07-MaS18 & Solid & $100 \%$ \\
\hline MAPEP-07-MaW18 & Water & $100 \%$ \\
\hline MAPEP-07-RdF18 & Air Filter & $100 \%$ \\
\hline MAPEP-07-MaV18 & Vegetation & $100 \%$ \\
\hline MAPEP-08-GrF19 & Air Filter & $100 \%$ \\
\hline MAPEP-08-GrW19 & Water & $100 \%$ \\
\hline MAPEP-08-MaS19 & Solid & $100 \%$ \\
\hline MAPEP-08-MaW19 & Water & $97 \%{ }^{2}$ \\
\hline MAPEP-08-RdF19 & Air Filter & $100 \%$ \\
\hline MAPEP-08-MaV19 & Vegetation & $100 \%$ \\
\hline \multicolumn{3}{|c|}{${ }^{1}$ Column presents percentage of tests that exceeded $80 \%$-acceptable-results level } \\
\hline
\end{tabular}


percentage was calculated by dividing the acceptable and the acceptable-with-warning results by the total number of results.

MAPEP intercomparison study results for EML can be found in the data tables section of the CD accompanying this report ["MAPEP Performance Study Series 18" and "MAPEP Performance Study Series 19"]. The MAPEP information has been copied from the actual MAPEP final report; "NR" in the report stands for "not reported," which indicates that the laboratory did not submit data for that particular analysis. The Flag column is used to denote if a result is Acceptable (A), Not Acceptable (N), Warning (W), etc., and the Uncertainty (Unc) Flag column is used to note uncertainty values that may be High $(\mathrm{H})$ or $(\mathrm{L})$, etc.

\section{QA for EM Sample Analyses}

Onsite and subcontract environmental laboratories providing analytical services must have documented QA programs and meet the quality requirements defined in the WSRC Quality Assurance Manual (WSRC 1Q).

An annual DOE Consolidated Audit Program (DOECAP) evaluation of each subcontract laboratory is performed to ensure that all the laboratories maintain technical competence and follow the required QA programs. The evaluation includes an examination of laboratory performance with regard to sample receipt, instrument calibration, analytical procedures, data verification, data reports, records management, nonconformance and corrective actions, and preventive maintenance. Reports of the findings and recommendations are provided to each laboratory, and follow-up evaluations are conducted as necessary. Evaluations were conducted at four laboratories in 2008, resulting in a total of 22 Priority II findings. A Priority II finding documents a deficiency which in and of itself does not represent a concern of sufficient magnitude to render the audited facility unacceptable to provide services to DOE. Each laboratory submits a corrective action response that addresses each finding. The findings are reviewed and typically closed during the next laboratory audit.

\section{Nonradiological Liquid Effluents}

National Pollutant Discharge Elimination System (NPDES) samples are analyzed by four onsite laboratory groups - EML, EM, the Site Infrastructure
\& Services Department (I\&SD), and Washington Safety Management Solutions (WSMS) - and one offsite subcontract laboratory, Shealy Environmental Services (SES). All these laboratories are certified by SCDHEC for NPDES analyses.

\section{Interlaboratory Program}

During 2008, all laboratories performing NPDES analyses for SRS participated in the EPA-required Discharge Monitoring Report (DMR) and Proficiency Testing Studies. All laboratories utilized Environmental Resource Associates (ERA) as the accredited Proficiency Testing provider. ERA, as required by EPA, is accredited by the American Association of Laboratory Accreditation.

EPA and SCDHEC use the study results to certify laboratories for specific analyses. As part of the recertification process, these agencies require that laboratories investigate the unacceptable results and implement corrective actions as appropriate.

WSMS participated in the 2008 DMR-QA Study 28, while SES, EM, EML, and I\&SD participated in ERA's water proficiency (WP)-160, WP-161, and WP-162 studies. All the studies' results were determined to be acceptable. Interlaboratory program results can be found in the data tables section of the $\mathrm{CD}$ accompanying this report ["Discharge Monitoring Report - Proficiency Test Results"].

\section{Intralaboratory Program}

The environmental monitoring intralaboratory program reviews laboratory performance by analyzing field duplicate and blind samples throughout the year.

The onsite and offsite laboratories processed 67 field duplicate analyses during 2008. Zero-difference results were reported for 49 of these analyses. Thirteen field duplicate analyses were between the zero and $\leq 20$-percent difference. Only five of the 67 field duplicate analyses exceeded the relative-percent $\leq$ 20-percent) difference.

The onsite and offsite laboratories processed 77 blind analyses during 2008. Zero-difference results were reported for 53 of these analyses. Nineteen field duplicate analyses were between the zero and $\leq 20$-percent difference. Only five of the 77 blind analyses exceeded the relative percent $(\leq 20$-percent) difference.

Results for the field duplicate and blind sam- 
Table 8-2

Subcontract-Laboratory Percent Acceptable Performance for Environmental Resource

Associates (ERA) Water Pollution Studies

Note: Laboratories met or exceeded the 80-percent-acceptable-results level.

\begin{tabular}{|c|c|c|}
\hline Study & General Engineering & TestAmerica \\
\hline WS-141 & $93 \% 10,14,18,19$ & $97 \% \%^{1,17}$ \\
\hline WS-146 & $99 \%^{12}$ & \\
\hline WS-147 & & $100 \%$ \\
\hline WP-159 & $100 \%$ & \\
\hline WP-161 & & $98 \% 2,3,4,5,8,9,13$ \\
\hline WP-162 & & $89 \% \%^{6,7,11,15,16}$ \\
\hline WP-164 & $100 \%$ & \\
\hline \multicolumn{3}{|l|}{ Results Not Acceptable } \\
\hline${ }^{1} 1,2,3$ trichloropropane (TCP) & ${ }^{8}$ Cobalt & 15 Toluene \\
\hline${ }^{2}$ Aroclor 1242 & ${ }^{9}$ Dalapon & ${ }^{16}$ Total organic halides (TOX) \\
\hline${ }^{3}$ Aroclor 1016 & ${ }^{10} \mathrm{DOC}$ & 17 Tetrachloroethylene \\
\hline${ }^{4}$ Alkalinity as $\mathrm{CaCO} 3$ & ${ }^{11}$ Ethylbenzene & 18 Turbidity \\
\hline${ }^{5}$ Ammonia as $\mathrm{N}$ & ${ }^{12}$ Heterotrophic plate count & ${ }^{19}$ Vanadium \\
\hline${ }^{6}$ Benzene in (GRO) & ${ }^{13}$ Orthophosphate as $\mathrm{P}$ & \\
\hline${ }^{7}$ Benzene & ${ }^{14}$ TOC & \\
\hline
\end{tabular}

pling programs indicated no consistent problems with the laboratories. Field duplicate and blind sample program results can be found in the data tables section of the CD accompanying this report ["NPDES Duplicate Sample Results" and "NPDES Blind Sample Results"].

\section{Stream and River Water Quality}

SRS's water quality program requires checks of 10 percent of the samples to verify analytical results. Duplicate grab samples from SRS streams and the Savannah River were analyzed by SES and EML in 2008. SES and EML reported approximately 3,000 analyses for this program. Greater than 95 percent of the approximately 1,100 field duplicate results were within acceptable limits ( $\leq 20$-percent difference). Results for the field duplicate sampling program indicated no consistent problems with the laboratories. Detailed stream and Savannah River field duplicate sample results can be found in the data tables section of the CD accompanying this report ["Duplicate Sample Results"].

\section{QA for DMWE Sample Analyses}

Groundwater analyses at SRS are performed by offsite (subcontract) and onsite laboratories. During 2008, General Engineering Laboratories and TestA merica, Inc., were the primary full-service subcontractors. The EML performed groundwater analyses for DMWE during 2008. Eberline Services Oak Ridge Lab (radiological only) and Lionville Laboratory (nonradiological only) were subcontracted laboratories; however, each was minimally used during 2008.

During 2008, General Engineering and TestAmerica participated in various WP and water supply (WS) studies. The WP study results (table 8-2) show that the laboratories met or exceeded the 80 -percentacceptable-results level. The table reflects only the 
Table 8-3

Subcontract-Laboratory Performance on Mixed-Analyte Performance Evaluation Program (MAPEP)

\begin{tabular}{|c|c|c|c|}
\hline Study & Matrix & General Engineering & TestAmerica \\
\hline MAPEP-07-MaS18 & Soil & $97 \% 1,[7], 8$ & $97 \%^{2,9,13}$ \\
\hline MAPEP-07-MaW18 & Water & $97 \%^{9}$ & $97 \% 6$ \\
\hline MAPEP-07-OrW18 & Water & $96 \%{ }^{[10],(11), 12}$ & $97 \%{ }^{12,(14)}$ \\
\hline MAPEP-07-GrW18 & Water & $100 \%$ & $100 \%$ \\
\hline MAPEP-08-MaS19 & Soil & $98 \%{ }^{3,(5)}$ & $98 \%{ }^{3,9}$ \\
\hline MAPEP-08-MaW19 & Water & $100 \%$ & $97 \%(9)$ \\
\hline MAPEP-08-OrW19 & Water & $99 \% 7$ & $99 \% 4$ \\
\hline MAPEP-08-GrW19 & Water & $100 \%$ & $100 \%$ \\
\hline $\begin{array}{l}{ }^{1} \text { Results for selenium w } \\
{ }^{2} \text { Results for antimony w } \\
{ }^{3} \text { Results for mercury we } \\
{ }^{4} \text { Results for gamma-BH } \\
{ }^{5} \text { Results for endrin keto } \\
{ }^{6} \text { Results for hydrogen-3 } \\
{ }^{7} \text { Results for heptachlor } \\
{ }^{8} \text { Results for iron-55 wer } \\
{ }^{9} \text { Results for nickel-63 w }\end{array}$ & $\begin{array}{l}\text { ceptable. } \\
\text { ceptable. } \\
\text { eptable. } \\
\text { were not acceptable. } \\
\text { t acceptable. } \\
\text { acceptable. } \\
\text { cceptable. } \\
\text { ptable. } \\
\text { eptable. }\end{array}$ & $\begin{array}{l}{ }^{10} \text { Results for benzo(a)ar } \\
{ }^{11} \text { Results for chrysene } \\
{ }^{12} \text { Results for hexachloro } \\
{ }^{13} \text { Results for bis(2-ethyll } \\
\text { acceptable. } \\
{ }^{14} \text { Results for methoxych } \\
\text { () False positive } \\
{ }^{[]} \text {False negative }\end{array}$ & $\begin{array}{l}\text { re not acceptable. } \\
\text { ptable. } \\
\text { te not acceptable. } \\
\text { te were not } \\
\text { acceptable. }\end{array}$ \\
\hline
\end{tabular}

studies associated with contracted analyses performed for SRS.

Results from the subcontract-laboratory performance on MAPEP are summarized in table 8-3. The results show that all laboratories exceeded the 80 -percent-acceptable-results level for all studies for both the soil and groundwater matrices. The air filter and vegetation matrices are not included in the subcontract-laboratory performance summary because these matrices are not part of the contract scope.

To help participants identify, investigate, and resolve potential quality concerns, the MAPEP issues a letter of concern to a participating laboratory upon identification of a potential analytical data quality problem in the MAPEP results. Letters of concern have been issued since 1996, shortly after the beginning of the MAPEP program. A copy of the letter is sent to DOE/contractor oversight points of contact (POCs), including DOE Field Office and Headquarters POCs and contractor sample management POCs. Intended to be informative and not punitive, each letter states,
"This letter is solely intended to alert your laboratory to a potential quality concern that you may wish to investigate for corrective action." Table 8-4 summarizes MAPEP concerns from 2008 for the primary full-service subcontracted laboratories.

\section{Soil/Sediment}

Environmental investigations of soils and sediments, primarily for RCRA/Comprehensive Environmental Response, Compensation, and Liability Act units, are performed by subcontract laboratories. Data are validated by DMWE according to EPA standards for analytical data quality, or as specified by SRS onsite customers.

The environmental validation program is based in part on two EPA guidance documents, "Guidance for the Data Quality Objectives Process for Superfund" (EPA-540-R-93-071) and "Systematic Planning: A Case Study for Hazardous Waste Site Investigations" (QA/CS-1) (EPA/240/B-06/004). These documents identify QA issues to be addressed, but they do not 
formulate a procedure for data evaluation or provide pass/fail criteria to apply to data and document acceptance. Hence, the SRS validation program contains elements from - and is influenced by - several other references, including

- "Guidance on Environmental Data Verification and Data Validation" (QA/G-8), EPA-240/R-02/004

- "USEPA Contract Laboratory Program National Functional Guidelines for Organic Data Review," EPA-540/R-99/008

- "USEPA Contract Laboratory Program National Functional Guidelines for Chlorinated Dioxin/ Furan Data Review," EPA-540/R-05/001

- "USEPA Contract Laboratory Program National Functional Guidelines for Inorganic Data Review," EPA-540/R-04/004

- "Test Methods for Evaluating Solid Waste, Physical/ Chemical Methods," EPA, November 1986, SW-846, Third Edition; Latest Update, February 2008

- "DOE Quality Systems for Analytical Services," Revision 2.4, October 2008

Many QA parameters are evaluated by automated processing of electronically reported data. Others are selectively evaluated by manual inspection of associated analytical records. A summary of findings is presented in each project narrative or validation report prepared by DMWE personnel.

\section{Data Review}

The QA program's detailed data review for groundwater and soil/sediment analyses is described in WSRC-3Q1-2, Section 1100.

One item that still required resolution in 2008 was closed as follows:

- Gas-flow proportional counting without daily cross-talk checks was resolved at two laboratories.

Items that are ongoing each year and are resolved on a case-by-case basis with each laboratory include

- incomplete record packages for validation

- omissions and logic failures in electronically reported data

The identification and resolution of quality and technical issues illustrates that, although laboratory procedures are well defined, analytical data quality does benefit from technical scrutiny.

Table 8-4

Subcontract-Laboratory Performance MAPEP Letters of Concern

\section{General Engineering}

Selenium (series 18)

\section{TestAmerica}

Antimony (series 18)

Hydrogen-3 (series 18)

Strontium-90 (series 18)

Nickel-63 (series 19) 



\title{
Applicable Guidelines, Standards, and Regulations
}

\author{
Jack Mayer
}

Savannah River National Laboratory
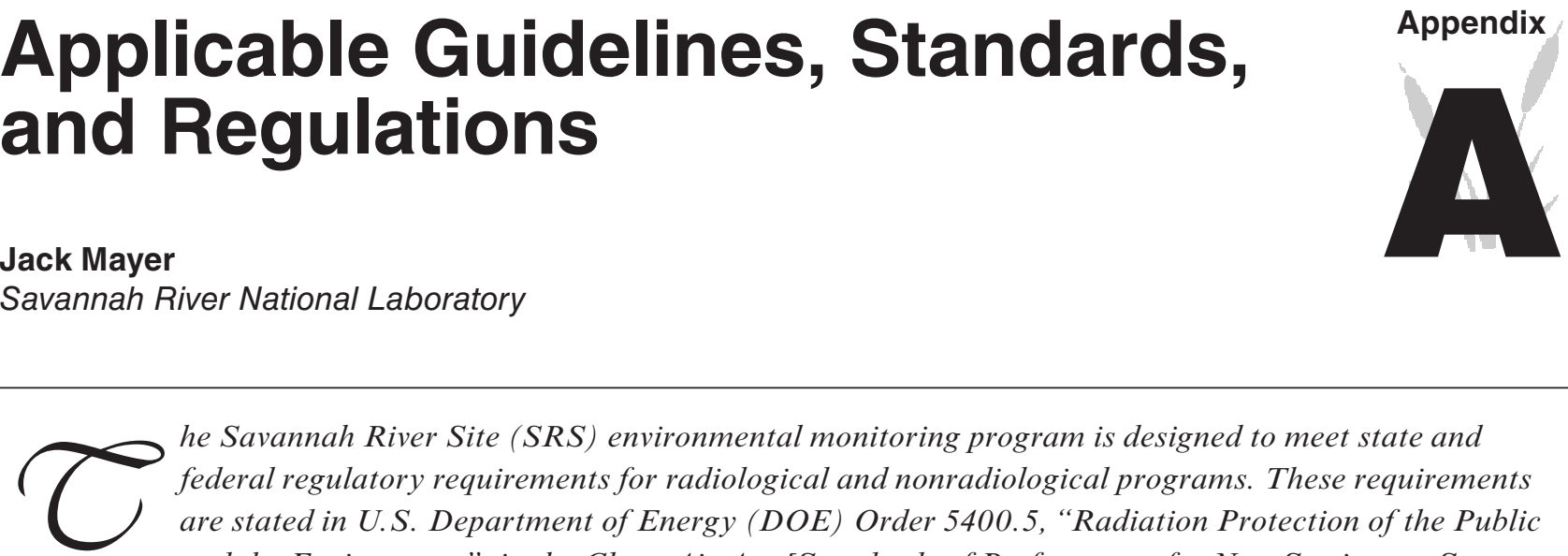

he Savannah River Site (SRS) environmental monitoring program is designed to meet state and federal regulatory requirements for radiological and nonradiological programs. These requirements are stated in U.S. Department of Energy (DOE) Order 5400.5, "Radiation Protection of the Public and the Environment"; in the Clean Air Act [Standards of Performance for New Stationary Sources, also referred to as New Source Performance Standards, and the National Emission Standards for Hazardous Air Pollutants (NESHAP)]; in the Comprehensive Environmental Response, Compensation, and Liability Act (CERCLA-also known as Superfund); in the Resource Conservation and Recovery Act (RCRA); in the Clean Water Act (i.e., National Pollutant Discharge Elimination System-NPDES); and in the National Environmental Policy Act (NEPA).

SRS compliance with environmental requirements is assessed by the DOE-Savannah River Operations Office (DOE-SR), the South Carolina Department of Health and Environmental Control (SCDHEC), and the U.S. Environmental Protection Agency (EPA).

The SRS environmental monitoring program's objectives incorporate recommendations of

- the International Commission on Radiological Protection (ICRP) in Principles of Monitoring for the Radiation Protection of the Public, ICRP Publication 43

\section{- $\quad$ DOE Order 5400.5}

- DOE/EH-0173T, "Environmental Regulatory Guide for Radiological Effluent Monitoring and Environmental Surveillance"

Detailed information about the site's environmental monitoring program is documented in Section 1100 (SRS Environmental Monitoring Program) of the SRS Environmental Monitoring Plans and Procedures, WSRC-3Q1-2, Volume 1. This document is reviewed annually and updated every 3 years.

SRS has implemented and adheres to the SRS Environmental Management System (EMS) Policy. Implementation of a formal EMS, such as that described in the International Organization for Standardization (ISO) 14001 standard, is an Executive Order 13148 ("Greening the Government Through Leadership in Environmental Management") and DOE Order 450.1A ("Environmental Protection Program") requirement. SRS maintains an EMS that fully meets the requirements of ISO 14001. The full text of the SRS EMS Policy appears in chapter 2, "Environmental Management System."

\section{Air Effluent Discharges}

DOE Order 5400.5 establishes derived concentration guides (DCGs) for radionuclides in air. DCGs, calculated by DOE using methodologies consistent with recommendations found in ICRP publications 26 (Recommendations of the International Commission on Radiological Protection) and 30 (Limits for Intakes of Radionuclides by Workers), are used as reference concentrations for conducting environmental protection programs at DOE sites. DCGs are not considered release limits. DCGs for radionuclides in air are discussed in more detail on page A-7.

Radiological airborne releases also are subject to EPA regulations cited in 40 CFR 61, "National Emission Standards for Hazardous Air Pollutants," Subpart H ("National Emission Standards for Emissions of Radionuclides Other than Radon from Department of Energy Facilities"). 
Table A-1

Criteria Air Pollutant Standards

\begin{tabular}{|c|c|c|}
\hline Pollutant & Measuring Interval & Concentration $\mathrm{a}, \mathrm{b}$ \\
\hline Sulfur Dioxide & $\begin{array}{l}3 \text { hours } \\
24 \text { hours } \\
\text { annual }\end{array}$ & $\begin{array}{l}1,300 \mu \mathrm{g} / \mathrm{m}^{3} \mathrm{c} \\
365 \mu \mathrm{g} / \mathrm{m}^{3} \mathrm{c} \\
80 \mu \mathrm{g} / \mathrm{m}^{3}\end{array}$ \\
\hline Total Suspended Particulates & annual geometric mean & $75 \mu \mathrm{g} / \mathrm{m}^{3}$ \\
\hline PM10 & 24 hours & $150 \mu \mathrm{g} / \mathrm{m}^{3} \mathrm{~d}$ \\
\hline PM2.5 (Primary and Secondary Standards) & 24 hours & $35 \mu \mathrm{g} / \mathrm{m}^{3 \mathrm{~d}}$ \\
\hline Carbon Monoxide & 1 hour & $40 \mathrm{mg} / \mathrm{m}^{3}$ \\
\hline Ozone & 8 hours & $0.08 \mathrm{ppm}^{\mathrm{d}}$ \\
\hline Gaseous Fluorides (as HF) & $\begin{array}{l}\text { 12-hour average } \\
\text { 24-hour average } \\
\text { 1-week average } \\
\text { 1-month average }\end{array}$ & $\begin{array}{l}3.7 \mu \mathrm{g} / \mathrm{m}^{3} \\
2.9 \mu \mathrm{g} / \mathrm{m}^{3} \\
1.6 \mu \mathrm{g} / \mathrm{m}^{3} \\
0.8 \mu \mathrm{g} / \mathrm{m}^{3}\end{array}$ \\
\hline Nitrogen Dioxide & annual & $100 \mu \mathrm{g} / \mathrm{m}^{3}$ \\
\hline Lead & calendar quarterly mean & $1.5 \mu \mathrm{g} / \mathrm{m}^{3}$ \\
\hline $\begin{array}{l}\text { a Arithmetic average except in case of total susper } \\
{ }^{\mathrm{b}} \text { At } 25^{\circ} \mathrm{C} \text { and } 760 \mathrm{~mm} \mathrm{Hg} \\
{ }^{\mathrm{c}} \text { Not to be exceeded more than once a year } \\
{ }^{\mathrm{d}} \text { Attainment determinations will be made based or }\end{array}$ & $\begin{array}{l}\text { articulate matter } \\
\text { riteria contained in } 40 \text { CFR50, }\end{array}$ & $\mathrm{H}, \mathrm{I}, \mathrm{K}$, and $\mathrm{N}$. \\
\hline
\end{tabular}

Regulation of radioactive and nonradioactive air emissions - both criteria pollutants and toxic air pollutants - has been delegated to SCDHEC. Therefore, SCDHEC must ensure that its air pollution regulations are at least as stringent as federal regulations required by the Clean Air Act. This is accomplished by SCDHEC Regulation 61-62, "Air Pollution Control Regulations and Standards." As with many regulations found in the Code of Federal Regulations (CFR), many of SCDHEC's regulations and standards are source specific. Each source of air pollution at SRS is permitted or exempted by SCDHEC, with specific emission rate limitations or special conditions identified. The bases for the limitations and conditions are the applicable South Carolina air pollution control regulations and standards. In some cases, specific applicable CFRs also are cited in the permits issued by SCDHEC. The applicable SCDHEC regulations are too numerous to discuss here, so only the most significant are listed.
Two SCDHEC standards, which govern criteria and toxic air pollutants and ambient air quality, are applicable to all SRS sources. Regulation 61-62.5, Standard No. 2, "Ambient Air Quality Standards," identifies eight criteria air pollutants commonly used as indices of air quality (e.g., sulfur dioxide, nitrogen dioxide, and lead) and provides allowable site boundary concentrations for each pollutant, as well as the measuring intervals. Compliance with the various pollutant standards is determined by conducting air dispersion modeling for all sources of each pollutant, using EPA-approved dispersion models and then comparing the results to the standard. The pollutants, measuring intervals, and allowable concentrations are provided in table A-1.

A total of 258 toxic air pollutants and their respective allowable site boundary concentrations are identified in Regulation 61-62.5, Standard No. 8, "Toxic Air Pollutants." As with Standard No. 2, compliance 
is determined by air dispersion modeling.

SCDHEC airborne emission standards for each SRS permitted source may differ, based on size and type of facility, type and amount of expected emissions, and the year the facility was placed into operation. For example, SRS powerhouse coal-fired boilers are regulated by Regulation 61-62.5, Standard No. 1, "Emissions from Fuel Burning Operations." This standard specifies that for powerhouse stacks built before February 11, 1971, the opacity limit is 40 percent. For new sources constructed after this date, the opacity limit typically is 20 percent. The standards for particulate and sulfur dioxide emissions are shown in table A-2.

Regulation 61-62.5, Standard No. 4, "Emissions from Process Industries," is applicable to all SRS sources except those regulated by a different sourcespecific standard. For some SRS sources, particulate matter emission limits depend on the weight of the material being processed and are determined from a table in the regulation. For process and diesel engine stacks in existence on or before December 31, 1985, emissions shall not exhibit an opacity greater than 40 percent. For new sources, where construction began after December 31, 1985, the opacity limit is 20 percent.

As previously noted, some SRS sources have both SCDHEC and CFRs applicable and identified in their permits. For the package steam generating boilers in K-Area and two portable package boilers, both SCDHEC and federal regulations apply. The standard for sulfur dioxide emissions is specified in 40 CFR 60, Subpart Dc, "Standards of Performance for Small Industrial-Commercial-Institutional Steam

Table A-2

Airborne Emission Limits for SRS Coal-Fired Boilers

\begin{tabular}{|ll|}
\hline Sulfur Dioxide & $3.5 \mathrm{lb} / 10^{6} \mathrm{Btu}^{\mathrm{a}, \mathrm{b}}$ \\
$\begin{array}{l}\text { Total Suspended } \\
\text { Particulates }\end{array}$ & $0.6 \mathrm{lb} / 10^{6} \mathrm{Btu}^{\mathrm{a}, \mathrm{b}}$ \\
Opacity & $40 \%$ \\
\hline British thermal unit & \\
\hline
\end{tabular}

Table A-3

Airborne Emission Limits for SRS Fuel Oil-Fired Package Boilers

\begin{tabular}{|c|c|}
\hline Sulfur Dioxide & $0.5 \mathrm{lb} / 10^{6} \mathrm{Btu}^{\mathrm{a}, \mathrm{b}}$ \\
\hline \multicolumn{2}{|l|}{ Total Suspended } \\
\hline Particulates & $0.6 \mathrm{lb} / 10^{6} \mathrm{Btu}^{\mathrm{a}, \mathrm{b}}$ \\
\hline Opacity & $20 \%$ \\
\hline \multicolumn{2}{|l|}{${ }^{a}$ British thermal unit } \\
\hline${ }^{\mathrm{b}}$ Heat input per hour & \\
\hline
\end{tabular}

Generating Units," while the standard for particulate matter is found in Regulation 61-62.5, Standard No. 1.

Because these units were constructed after applicability dates found in both regulations, the opacity limit for the units is the same in both regulations. The emissions standards for these boilers are presented in table A-3.

In September 2008, the existing coal-fired A-Area boilers were replaced with a new steam facility that uses a smaller, less polluting, biomass boiler and a backup oil-fired boiler. The new facility complies with 40 CFR 63, Subpart DDDDD standards. Both particulate and sulfur dioxide emissions at the new facility are projected to be considerably lower than at the existing coal-fired facility. The emission standards for these two new boilers are presented in tables A-4 and A-5.

\section{(Process) Liquid Effluent Discharges}

DOE Order 5400.5 establishes DCGs for radionuclides in process effluents. (DCGs for radionuclides in liquid are discussed in more detail on page 75.) DCGs were calculated by DOE using methodologies consistent with recommendations found in ICRP, 1987, and ICRP, 1979, and are used

- as reference concentrations for conducting environmental protection programs at DOE sites

- as screening values for considering best available technology for treatment of liquid effluents 


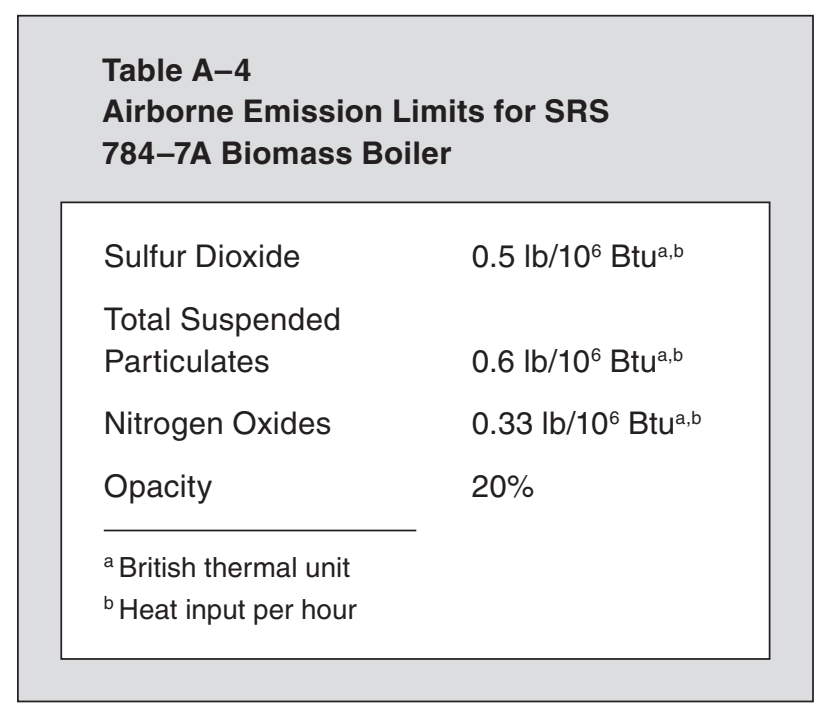

- DOE Order 5400.5 exempts aqueous tritium releases from best available technology requirements but not from ALARA (as low as reasonably achievable) considerations.

Four NPDES permits are in place that allow SRS to discharge water into site streams and the Savannah River: two industrial wastewater permits (SC0047431 and SC0000175) and two stormwater runoff permits (SCR000000 for industrial discharges and SCR100000 for construction discharges).

A fifth permit (ND0072125) is a no-discharge waterpollution-control land application permit that regulates sludge generated at onsite sanitary waste treatment plants.

Detailed requirements for each permitted discharge point - including parameters sampled for, permit limits for each parameter, sampling frequency, and method for collecting each sample — can be found in the individual permits, which are available to the public through SCDHEC's Freedom of Information Office at 803-898-3882.

\section{Site Streams}

SRS streams are classified as "Freshwaters" by South Carolina Regulation 61-69, "Classified Waters." Freshwaters are defined in Regulation 61-68, "Water Classifications and Standards," as surface water suitable for

- primary- and secondary-contact recreation and as a drinking water source after conventional treatment in accordance with SCDHEC requirements
- fishing and the survival and propagation of a balanced indigenous aquatic community of fauna and flora

- industrial and agricultural uses

Table A-6 provides some of the specific South Carolina freshwater standards used in water quality surveillance, but because some of these standards are not quantifiable, they are not tracked in response form (i.e., amount of garbage found).

\section{Savannah River}

Because the Savannah River is defined under South Carolina Regulation 61-69 as a freshwater system, the river is regulated in the same manner as site streams (table A-6).

\section{Drinking Water}

The federal Safe Drinking Water Act—enacted in 1974 to protect public drinking water supplies - was amended in 1977, 1979, 1980, 1986, and 1996.

SRS drinking water systems are tested routinely by SRS and SCDHEC to ensure compliance with SCDHEC State Primary Drinking Water Regulations (R61-58) and EPA National Primary Drinking Water Regulations (40 CFR 141).

Table A-5

Airborne Emission Limits for SRS 784-7A Oil-Fired Package Boiler

\begin{tabular}{|ll|}
\hline $\begin{array}{l}\text { Sulfur Dioxide } \\
\text { Sulfur Dioxide }\end{array}$ & $3.5 \mathrm{lb} / 10^{6} \mathrm{Btu}^{\mathrm{a}, \mathrm{b}}$ \\
$\begin{array}{l}\text { Total Suspended } \\
\text { Particulates }\end{array}$ & $0.5 \%$ Sulfur \\
Total Suspended & $0.6 \mathrm{lb} / 10^{6} \mathrm{Btu}^{\mathrm{a}, \mathrm{b}}$ \\
Particulates & $0.03 \mathrm{lb} / 10^{6} \mathrm{Btu}^{\mathrm{a}, \mathrm{b}}$ \\
$\begin{array}{l}\text { Nitrogen Dioxide } \\
\text { Opacity }\end{array}$ & $0.15 \mathrm{lb} / 10^{6} \mathrm{Btu}^{\mathrm{a}, \mathrm{b}}$ \\
$\begin{array}{l}{ }^{\mathrm{a}} \text { British thermal unit } \\
{ }^{\mathrm{b}} \text { Heat input per hour }\end{array}$ & $20 \%$ \\
\hline
\end{tabular}


Table A-6

South Carolina Water Quality Standards for Freshwaters ${ }^{a}$

Parameters

Fecal coliform

$\mathrm{pH}$

Temperature

Dissolved oxygen

Garbage, cinders, ashes, sludge, or other refuse

Treated wastes, toxic wastes, deleterious substances, colored or other wastes, except in the parameter immediately above

Toxic pollutants listed in South Carolina Regulation 61-68, "Water Classifications and Standards"

\section{Standards}

Not to exceed a geometric mean of $200 / 100 \mathrm{~mL}$, based on five consecutive samples during any 30-day period; nor shall more than 10 percent of the total samples during any 30 -day period exceed 400/100 mL

Range between 6.0 and 8.5

Generally, shall not be increased more than $5^{\circ} \mathrm{F}$ $\left(2.8^{\circ} \mathrm{C}\right)$ above natural temperature conditions or be permitted to exceed a maximum of $90^{\circ} \mathrm{F}\left(32.2^{\circ} \mathrm{C}\right)$ as a result of the discharge of heated liquids; for more details, see E.12, Regulation 61-68, "Water Classifi cations and Standards" (April 25, 2008)

Daily average not less than $5.0 \mathrm{mg} / \mathrm{L}$, with a low of $4.0 \mathrm{mg} / \mathrm{L}$

None allowed

None alone or in combination with other substances of wastes in sufficient amounts to make the waters unsafe or unsuitable for primary-contact recreation or to impair the waters for any other best usage as determined for the specific waters assigned to this class

See Appendix: Water Quality Numeric Criteria for the Protection of Aquatic Life and Human Health, Regulation 61-68, "Water Classifications and Standards" (April 25, 2008)

${ }^{a}$ This is a partial list of water quality standards for freshwaters.

SRS drinking water is supplied by seven regulated systems, all of which utilize groundwater sources. The A-Area, D-Area, and K-Area systems are actively regulated by SCDHEC, while the remaining four site water systems receive a reduced level of regulatory oversight.

The A-Area, D-Area, and K-Area drinking water systems are sampled periodically for lead and copper; however, none of these systems were sampled for these constituents in 2008. The D-Area and K-Area systems will be resampled for lead and copper in 2009, while the A-Area system is scheduled to be resampled in 2010 .

The B-Area Bottled Water Facility, which requires periodic inspections to continue operating, was shut down permanently in September 2008. Maintenance upgrades required to continue operating the facility were determined to be too costly, so it was decided that SRS's bottled water needs could be met more cost-effectively through use of an offsite vendor. The facility was not in operation during 2008, but SCDHEC Bureau of Environmental Health person- 
nel did conduct two quarterly inspections (in March and June). No significant issues were identified during those inspections.

\section{Groundwater}

Groundwater is a valuable resource and is the subject of both protection and cleanup programs at SRS. More than 1,000 wells are monitored each year at the site for a wide range of constituents. Monitoring in the groundwater protection program is performed to detect new or unknown contamination across the site, and monitoring in the groundwater cleanup program is performed to meet the requirements of state and federal laws and regulations. Most of the monitoring in the cleanup program is governed by SCDHEC's administration of RCRA regulations.

The analytical results of samples taken from SRS monitoring wells are compared to various standards. The most common are final federal primary drinking water standards (DWS) — or other standards if DWS do not exist. The DWS are considered first because groundwater aquifers are defined as potential drinking water sources by the South Carolina Pollution Control Act. DWS can be found at http://www.epa. gov/safewater/standards.html on the Internet. Other standards sometimes are applied by regulatory agencies to the SRS waste units under their jurisdiction. For example, standards under RCRA can include DWS, groundwater protection standards, background levels, or alternate concentration limits.

SRS responses to groundwater analytical results require careful evaluation of the data and relevant standards. Results from two constituents having DWS - dichloromethane and bis (2-ethylhexyl) phthalate - are evaluated more closely than other constituents and are commonly dismissed. Both are common laboratory contaminants and are reported in groundwater samples with little or no reproducibility. Both are reported, with appropriate flags and qualifiers, in detailed groundwater monitoring results that can be obtained by contacting the manager of the Savannah River Nuclear Solutions (SRNS) Environmental Monitoring group at 803952-8247. Also, the SCDHEC standard used for lead is $50 \mu \mathrm{g} / \mathrm{L}$. The federal standard of $15 \mu \mathrm{g} / \mathrm{L}$ is a treatment standard for drinking water at the consumer's tap.

The regulatory standards for radionuclide discharges from industrial and governmental facilities are set under the Clean Water Act and under Nuclear Regulatory Commission and DOE regulations. In addition, radionuclide cleanup levels, which fall under the authority of DOE, are included in the site RCRA permit. The proposed drinking water maximum contaminant levels (MCLs) discussed in this report are only an adjunct to these release restrictions and are not used to regulate SRS groundwater.

Many potential radionuclide contaminants are beta emitters. The standard used for gross beta is a screening standard; when public drinking water exceeds this standard, the supplier is expected to analyze for individual beta and gamma emitters. A gross beta result above the standard is an indication that one or more radioisotopes are present in quantities that would exceed the EPA annual dose equivalent for persons consuming 2 liters daily. Thus, for the individual beta and gamma radioisotopes (other than strontium- 90 and tritium), the standard considered is the activity per liter that would, if only that isotope were present, exceed the dose equivalent. Similarly, the standards for alpha emitters are calculated to present the same risk at the same rate of ingestion.

The element radium has several isotopes of concern in groundwater monitoring. Although radium has a DWS of $5 \mathrm{pCi} / \mathrm{L}$ for the sum of radium-226 and radium-228, the isotopes have to be measured separately, and the combined numbers may not be representative of the total. Radium-226, an alpha emitter, and radium-228, a beta emitter, cannot be analyzed by a single method. Analyses for total alpha-emitting radium, which consists of radium-223, radium-224, and radium-226, are compared to the standard for radium-226.

Four other constituents without DWS are commonly used as indicators of potential contamination in wells.

These constituents are

- specific conductance at values equal to or greater than $100 \mu \mathrm{S} / \mathrm{cm}$

- alkalinity (as $\mathrm{CaCO}_{3}$ ) at values equal to or greater than $120 \mathrm{mg} / \mathrm{L}$

- total dissolved solids (TDS) at values equal to or greater than $500 \mathrm{mg} / \mathrm{L}$ 
- $\mathrm{pH}$ at values equal to or less than 6.5 or equal to or greater than 8.5

The selection of these values as standards for comparison is somewhat arbitrary; however, the values exceed levels usually found in background wells at SRS. The occurrence of elevated alkalinity (as $\mathrm{CaCO}_{3}$ ), specific conductance, $\mathrm{pH}$, and TDS within a single well also may indicate leaching of the grouting material used in well construction, rather than degradation of the groundwater.

\section{Potential Doses}

The radiation protection standards followed by SRS are outlined in DOE Order 5400.5 and include EPA regulations on the potential doses from airborne releases and treated drinking water.

The following radiation dose standards for protection of the public in the SRS vicinity are specified in DOE Order 5400.5:

Drinking Water Pathway Airborne Pathway 4 mrem per year All Pathway .10 mrem per year The EPA annual dose standard of $10 \mathrm{mrem}(0.1 \mathrm{mSv})$ for the atmospheric pathway, which is contained in 40 CFR 61, Subpart H, is adopted in DOE Order 5400.5 .

These dose standards are based on recommendations of the ICRP and the National Council on Radiation Protection and Measurements.

The DOE dose standard enforced at SRS for drinking water is consistent with the criteria contained in "National Interim Primary Drinking Water Regulations, 40 CFR Part 141." Under these regulations, persons consuming drinking water shall not receive an annual total body or organ dose-DOE Order 5400.5 interprets this dose as committed effective dose equivalent — of more than $4 \mathrm{mrem}(0.04 \mathrm{mSv})$.

In 2000, EPA promulgated 40 CFR, Parts 9, 141, and 142, "National Primary Drinking Water Regulations; Radionuclides; Final Rule." This rule, which is applicable only to community drinking water systems, finalized MCLs for radionuclides, including uranium. In essence, it reestablishes the MCLs from EPA's original 1976 rule. Most of these MCLs are derived from dose conversion factors that are based on early ICRP-2 methods.

However, when calculating dose, SRS must use the more current ICRP-30-based dose conversion factors provided by DOE. Because they are based on different methods, most EPA and DOE radionuclide dose conversion factors differ. Therefore, a direct comparison of the drinking water doses calculated for showing compliance with DOE Order 5400.5 to the EPA drinking water MCLs cannot be made.

\section{Comparison of Average Concentrations in Airborne Emissions to DOE Derived Concentration Guides}

Average concentrations of radionuclides in airborne emissions are calculated by dividing the yearly release total of each radionuclide from each stack by the yearly stack flow quantities. These average concentrations then can be compared to the DOE DCGs, which are found in DOE Order 5400.5 for each radionuclide.

DCGs are used as reference concentrations for conducting environmental protection programs at all DOE sites. DCGs, which are based on a $100-\mathrm{mrem}$ exposure, are applicable at the point of discharge (prior to dilution or dispersion) under conditions of continuous exposure (assumed to be an average inhalation rate of 8,400 cubic meters per year). This means that the DOE DCGs are based on the highly conservative assumption that a member of the public has direct access to, and continuously breathes (or is immersed in), the actual air effluent 24 hours a day, 365 days a year. However, because of the large distance between most SRS operating facilities and the site boundary, this scenario is improbable.

Average annual radionuclide concentrations in SRS air effluent can be referenced to DOE DCGs as a screening method to determine if existing effluent treatment systems are proper and effective.

\section{Comparison of Average Concentrations in Liquid Releases to DOE Derived Concentration Guides}

In addition to dose standards, DOE Order 5400.5 imposes other control considerations on liquid releases. These considerations are applicable to direct discharges but not to seepage basin and Solid Waste Disposal Facility migration discharges. The DOE order lists DCG values for most radionuclides. 
DCGs are used as reference concentrations for conducting environmental protection programs at all DOE sites. These DCG values are not release limits but screening values for best-available-technology investigations and for determining whether existing effluent treatment systems are proper and effective.

Per DOE Order 5400.5, exceedance of the DCGs at any discharge point may require an investigation of best-available-technology waste treatment for the liquid effluents. Tritium in liquid effluents is specifically excluded from best available technology requirements; however, it is not excluded from other ALARA considerations. DOE DCG compliance is demonstrated when the sum of the fractional DCG values for all radionuclides detectable in the effluent is less than 1.00, based on consecutive 12-month average concentrations.

DCGs, based on a 100-mrem exposure, are applicable at the point of discharge from the effluent conduit to the environment (prior to dilution or dispersion). They are based on the highly conservative assumption that a member of the public has continuous direct access to the actual liquid effluents and consumes 2 liters of the effluents every day, 365 days a year. Because of security controls and the considerable distances between most SRS operating facilities and the site boundary, this scenario is highly improbable, if not impossible.

For each SRS facility that releases radioactivity, the site's Environmental Monitoring group compares the monthly liquid effluent concentrations and 12-month average concentrations against the DOE DCGs.

\section{Environmental Management}

SRS began its cleanup program in 1981. Two major federal statutes provide guidance for the site's environmental restoration and waste management activities-RCRA and CERCLA. RCRA addresses the management of hazardous waste and requires that permits be obtained for facilities that treat, store, or dispose of hazardous or mixed waste. It also requires that DOE facilities perform appropriate corrective action to address contaminants in the environment. CERCLA (also known as Superfund) addresses the uncontrolled release of hazardous substances and the cleanup of inactive waste sites. This act established a National Priority List of sites targeted for assessment and, if necessary, corrective/remedial action. SRS was placed on this list December 21,
1989 [EPA, 1989]. In August 1993, SRS entered into the Federal Facility Agreement (FFA) [FFA, 1993] with EPA Region IV and SCDHEC. This agreement governs the corrective/remedial action process from site investigation through site remediation. It also describes procedures for setting annual work priorities, including schedules and deadlines, for that process [FFA under section 120 of CERCLA and sections 3008(h) and 6001 of RCRA].

Additionally, DOE is complying with Federal Facility Compliance Act requirements for mixed waste management - including high-level waste, most transuranic waste, and low-level waste with hazardous constituents. This act requires that DOE develop and submit site treatment plans to the EPA or state regulators for approval.

The disposition of facilities after they are declared excess to the government's mission is managed by Site Area Completion Projects. The disposition process is conducted in accordance with DOE Order 430.1B, "Real Property Asset Management," and its associated guidance documents. The major emphases are reducing risks to workers and the public and minimizing real property asset lifecycle costs.

\section{Quality Assurance/Quality Control}

DOE Order 414.1C, "Quality Assurance," sets requirements and guidelines for departmental quality assurance (QA) practices. To ensure compliance with regulations and to provide overall quality requirements for site programs, the previous site management and operations contractor, Washington Savannah River Company (WSRC), developed its Quality Assurance Management Plan, Rev. 21 (WSRC-RP92-225). The plan's requirements are implemented by the WSRC Quality Assurance Manual (WSRC 1Q).

The SRS Environmental Monitoring Section Quality Assurance Plan (WSRC-3Q1-2, Volume 3, Section 8000), was written to apply the QA requirements of WSRC 1Q to the environmental monitoring and surveillance program. The WSRC-3Q1 series includes procedures on sampling, radiochemistry, and water quality that emphasize the quality control requirements for the Environmental Monitoring group.

QA requirements for monitoring radiological air emissions are specified in 40 CFR 61, "National Emission Standards for Hazardous Air Pollutants." For radiological air emissions at SRS, the respon- 
sibilities and lines of communication are detailed in National Emission Standards for Hazardous Air Pollutants Quality Assurance Project Plan for Radionuclides (U) (WSRC-IM-91-60).

To ensure valid and defensible monitoring data, the records and data generated by the monitoring program are maintained according to the requirements of DOE Guide 1324.5B, "Implementation Guide for Use with 36 CFR Chapter XII - Subchapter B Records Management," and of WSRC 1Q. QA records include sampling and analytical procedure manuals, logbooks, chain-of-custody forms, calibration and training records, analytical notebooks, control charts, validated laboratory data, and environmental reports. These records are maintained and stored per the requirements of WSRC Retention Schedule Matrix (WSRC-EM-96-00023).

Environmental Monitoring group assessments are implemented according to the following documents:

- DOE Order 414.1C

- DOE/EH-0173T
- DOE Environmental Management Consolidated Audit Program (EMCAP)

- WSRC 1Q, Quality Assurance Manual

- WSRC 12Q, Assessment Manual

Figure A-1 illustrates the hierarchy of relevant guidance documents that support the SRS QA program.

\section{Reporting}

DOE Orders 231.1A, "Environment, Safety and Health Reporting," and 5400.5, "Radiation Protection of the Public and Environment," require that SRS submit an annual environmental report.

This report, the SRS Environmental Report for 2008, is an overview of effluent monitoring and environmental surveillance activities conducted on and in the vicinity of SRS from January 1 through December 31, 2008. 


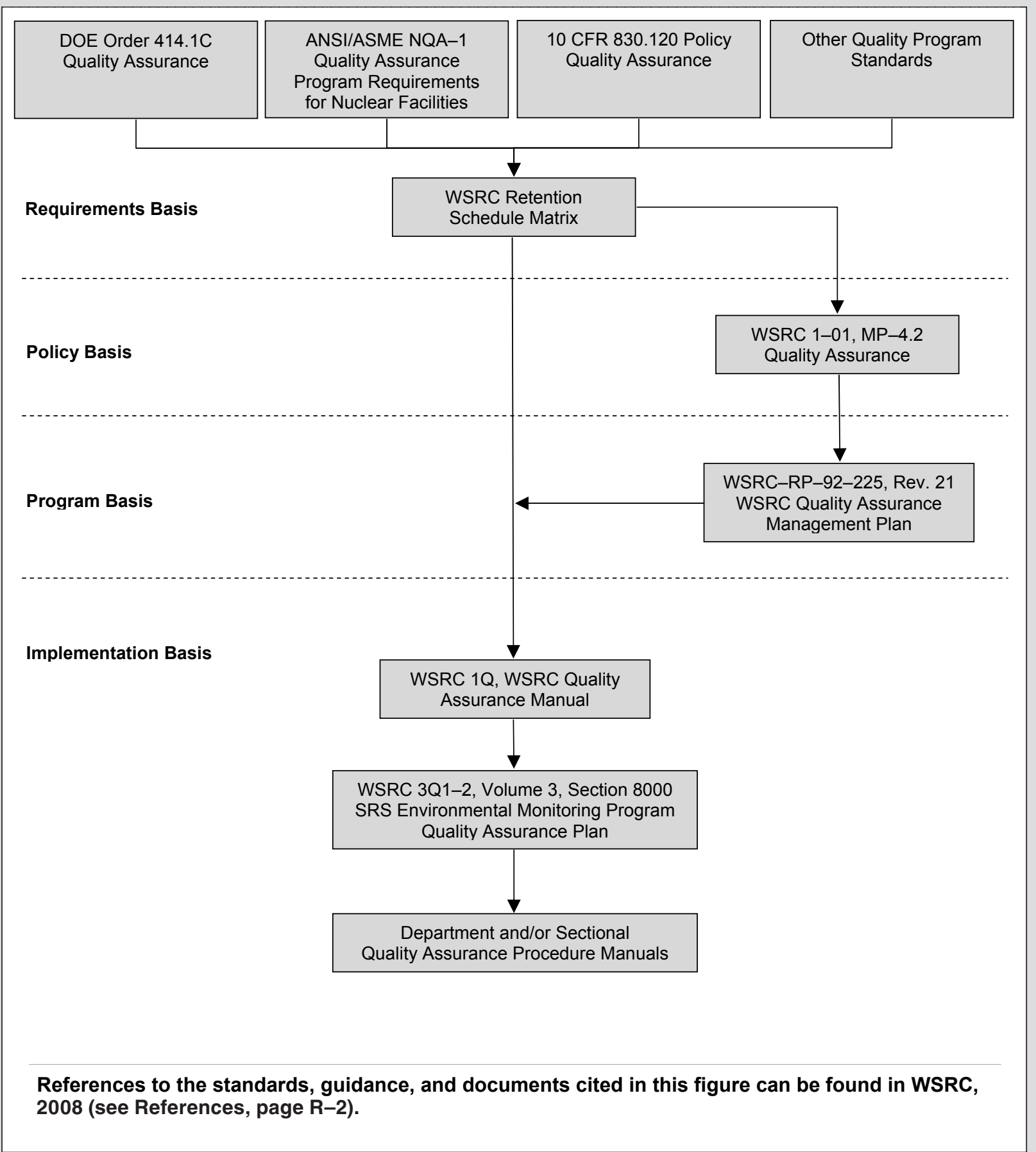

Figure A-1 SRS EM Program QA Document Hierarchy

This diagram depicts the hierarchy of relevant guidance and supporting documents for the SRS QA program. 


\section{Radionuclide and Chemical Nomenclature}

\begin{tabular}{|c|c|c|c|c|c|}
\hline \multirow[b]{2}{*}{ Radionuclide } & \multicolumn{4}{|c|}{ Nomenclature and Half-Life for Radionuclides } & \multirow[b]{2}{*}{ Half-life $e^{a, b}$} \\
\hline & Symbol & Half-life ${ }^{a, b}$ & Radionuclide & Symbol & \\
\hline Actinium-228 & Ac-228 & $6.15 \mathrm{~h}$ & lodine-129 & $\mathrm{I}-129$ & 1.57E7 y \\
\hline Americium-241 & Am-241 & $432.7 \mathrm{y}$ & lodine-131 & $\mid-131$ & $8.020 \mathrm{~d}$ \\
\hline Americium-243 & Am-243 & $7370 y$ & lodine-133 & $\mid-133$ & $20.8 \mathrm{~h}$ \\
\hline Antimony-124 & Sb-124 & $60.20 \mathrm{~d}$ & Krypton-85 & $\mathrm{Kr}-85$ & $10.76 \mathrm{y}$ \\
\hline Antimony-125 & Sb-125 & 2.758 y & Lead-212 & $\mathrm{Pb}-212$ & $10.64 \mathrm{~h}$ \\
\hline Argon-39 & Ar-39 & 269 y & Lead-214 & $\mathrm{Pb}-214$ & $27 \mathrm{~m}$ \\
\hline Barium-133 & Ba-133 & $10.53 y$ & Manganese-54 & Mn-54 & $312.1 d$ \\
\hline Beryllium-7 & $\mathrm{Be}-7$ & $53.3 d$ & Mercury-203 & $\mathrm{Hg}-203$ & $46.61 \mathrm{~d}$ \\
\hline Bismuth-212 & $\mathrm{Bi}-212$ & $1.009 \mathrm{~h}$ & Neptunium-237 & Np-237 & $2.14 \mathrm{E} 6 \mathrm{y}$ \\
\hline Bismuth-214 & $\mathrm{Bi}-214$ & $19.9 \mathrm{~m}$ & Neptunium-239 & Np-239 & $2.355 d$ \\
\hline Carbon-14 & $C-14$ & $5715 y$ & Nickel-59 & $\mathrm{Ni}-59$ & $7.6 \mathrm{E} 4 \mathrm{y}$ \\
\hline Cerium-141 & Ce-141 & $32.50 \mathrm{~d}$ & Nickel-63 & $\mathrm{Ni}-63$ & $101 \mathrm{y}$ \\
\hline Cerium-144 & Ce-144 & $284.6 \mathrm{~d}$ & Niobium-94 & $\mathrm{Nb}-94$ & $2.0 \mathrm{E} 4 \mathrm{y}$ \\
\hline Cesium-134 & Cs-134 & $2.065 \mathrm{y}$ & Niobium-95 & $\mathrm{Nb}-95$ & $34.99 \mathrm{~d}$ \\
\hline Cesium-137 & Cs-137 & $30.07 y$ & Plutonium-238 & Pu-238 & 87.7 y \\
\hline Chromium-51 & Cr-51 & $27.702 \mathrm{~d}$ & Plutonium-239 & Pu-239 & $2.41 \mathrm{E} 4 \mathrm{y}$ \\
\hline Cobalt-57 & Co-57 & $271.8 d$ & Plutonium-240 & Pu-240 & $6560 y$ \\
\hline Cobalt-58 & Co-58 & $70.88 d$ & Plutonium-241 & Pu-241 & $14.4 \mathrm{y}$ \\
\hline Cobalt-60 & Co-60 & $5.271 \mathrm{y}$ & Plutonium-242 & Pu-242 & 3.75E5 y \\
\hline Curium-242 & $\mathrm{Cm}-242$ & $162.8 d$ & Potassium-40 & $\mathrm{K}-40$ & $1.27 \mathrm{E} 9 \mathrm{y}$ \\
\hline Curium-244 & $\mathrm{Cm}-244$ & $18.1 \mathrm{y}$ & Praseodymium-144 & Pr-144 & $17.28 \mathrm{~m}$ \\
\hline Curium-245 & $\mathrm{Cm}-245$ & 8.5E3 y & Praseodymium-144m & Pr-144m & $7.2 \mathrm{~m}$ \\
\hline Curium-246 & $\mathrm{Cm}-246$ & 4.76E3 y & Promethium-147 & Pm-147 & $2.6234 \mathrm{y}$ \\
\hline Europium-152 & Eu-152 & 13.54 y & Protactinium-231 & $\mathrm{Pa}-231$ & $3.28 \mathrm{E} 4$ y \\
\hline Europium-154 & Eu-154 & 8.593 y & Protactinium-233 & $\mathrm{Pa}-233$ & $26.967 d$ \\
\hline Europium-155 & Eu-155 & $4.75 y$ & Protactinium-234 & Pa-234 & $6.69 \mathrm{~h}$ \\
\hline
\end{tabular}




\begin{tabular}{|c|c|c|c|c|c|}
\hline \multicolumn{6}{|c|}{ Nomenclature and Half-Life for Radionuclides } \\
\hline Radionuclide & Symbol & Half-life ${ }^{a, b}$ & Radionuclide & Symbol & Half-life ${ }^{a, b}$ \\
\hline Radium-226 & $\mathrm{Ra}-226$ & 1599 y & Thorium-234 & Th-234 & $24.10 \mathrm{~d}$ \\
\hline Radium-228 & Ra-228 & 5.76 y & Tin-113 & Sn-113 & $115.1 \mathrm{~d}$ \\
\hline Ruthenium-103 & $\mathrm{Ru}-103$ & $39.27 \mathrm{~d}$ & Tin-126 & Sn-126 & 2.3E5 y \\
\hline Ruthenium-106 & $\mathrm{Ru}-106$ & 1.020 y & Tritium (Hydrogen-3) & $\mathrm{H}-3$ & 12.32 y \\
\hline Selenium-75 & Se-75 & $119.78 \mathrm{~d}$ & Uranium-232 & U-232 & 69.8 y \\
\hline Selenium-79 & Se-79 & $2.9 \mathrm{E} 5 \mathrm{y}$ & Uranium-233 & U-233 & 1.592E5 y \\
\hline Sodium-22 & Na-22 & 2.604 y & Uranium-234 & U-234 & 2.46E5 y \\
\hline Strontium-89 & Sr-89 & $50.52 \mathrm{~d}$ & Uranium-235 & U-235 & 7.04E8 y \\
\hline Strontium-90 & Sr-90 & 28.78 y & Uranium-236 & U-236 & 2.342E7 y \\
\hline Technetium-99 & Tc-99 & 2.13E5 y & Uranium-238 & U-238 & 4.47E9 y \\
\hline Thallium-208 & TI-208 & $3.053 \mathrm{~m}$ & Xenon-135 & Xe-135 & $9.10 \mathrm{~h}$ \\
\hline Thorium-228 & Th-228 & 1.912 y & Zinc-65 & Zn-65 & $243.8 d$ \\
\hline Thorium-230 & Th-230 & 7.54E4 y & Zirconium-85 & Zr-85 & $7.9 \mathrm{~m}$ \\
\hline Thorium-232 & Th-232 & 1.40E10 y & Zirconium-95 & Zr-95 & $64.02 \mathrm{~d}$ \\
\hline $\begin{array}{l}{ }^{\mathrm{a}} \mathrm{m}=\text { minute; } \mathrm{h}=\mathrm{l} \\
{ }^{\mathrm{b}} \text { Reference: Char }\end{array}$ & $\begin{array}{l}y ; y=\text { yea } \\
\text { lides, 16th }\end{array}$ & ition, revise & ockheed Martin Com & & \\
\hline
\end{tabular}


The following entry corrects information that was reported inaccurately in the Savannah River Site Environmental Report for 2007 (WSRC-STI-2008-00057):

- Two values were entered incorrectly in the MAXDOSE-SR calculations for the 2007 SRS radiological releases. The $\mathrm{Cm}-224$ release value was entered as 1.49E-60 curies; the correct value is $1.49 \mathrm{E}-06$ curies. The alpha release value was entered as 6.24E-04 curies; the correct value is 6.24E-06 curies. MAXDOSE-SR was used to calculate dose considering cow milk and goat milk. The values were entered incorrectly in both cow and goat milk calculations. The dose considering cow milk was reported as $4.21 \mathrm{E}-02 \mathrm{mrem}$; the correct dose is $3.98 \mathrm{E}-02 \mathrm{mrem}$. The dose considering goat milk was reported as $4.75 \mathrm{E}-02 \mathrm{mrem}$; the correct dose is $4.52 \mathrm{E}-02$ mrem. 



\section{Glossary}

$\mathbf{A}$

accuracy - Closeness of the result of a

measurement to the true value of the quantity.

actinide - Group of elements of atomic number 89 through 103. Laboratory analysis of actinides by alpha spectrometry generally refers to the elements plutonium, americium, uranium, and curium but may also include neptunium and thorium.

activity - See radioactivity.

air flow - Rate of flow, measured by mass or volume per unit of time.

air stripping - Process used to decontaminate groundwater by pumping the water to the surface, "stripping" or evaporating the chemicals in a specially designed tower, and pumping the cleansed water back to the environment.

aliquot - Quantity of sample being used for analysis.

alkalinity - Alkalinity is a measure of the buffering capacity of water, and since $\mathrm{pH}$ has a direct effect on organisms as well as an indirect effect on the toxicity of certain other pollutants in the water, the buffering capacity is important to water quality.

alpha particle - Positively charged particle emitted from the nucleus of an atom having the same charge and mass as that of a helium nucleus (two protons and two neutrons).

ambient air - Surrounding atmosphere as it exists around people, plants, and structures.

analyte - Constituent or parameter that is being analyzed.

analytical detection limit - Lowest reasonably accurate concentration of an analyte that can be detected; this value varies depending on the method, instrument, and dilution used.

aquifer - Saturated, permeable geologic unit that can transmit significant quantities of water under ordinary hydraulic gradients.

aquitard - Geologic unit that inhibits the flow of water.

Atomic Energy Commission - Federal agency created in 1946 to manage the development, use, and control of nuclear energy for military and civilian application. It was abolished by the Energy Reorganization Act of 1974 and succeeded by the Energy Research and Development Administration. Functions of the Energy Research and Development Administration eventually were taken over by the U.S. Department of Energy and the U.S. Nuclear Regulatory Commission.

B background radiation - Naturally occurring radiation, fallout, and cosmic radiation. Generally, the lowest level of radiation obtainable within the scope of an analytical measurement, i.e., a blank sample.

bailer - Container lowered into a well to remove water. The bailer is allowed to fill with water and then is removed from the well.

best management practices - Sound engineering practices that are not required by regulation or by law.

beta particle - Negatively charged particle emitted from the nucleus of an atom. It has a mass and charge equal to those of an electron.

blank - Control sample that is identical, in principle, to the sample of interest, except that the substance being analyzed is absent. In such cases, the measured value or signal for the substance being analyzed is believed to be due to artifacts. Under certain 
circumstances, that value may be subtracted from the measured value to give a net result reflecting the amount of the substance in the sample. The U.S. Environmental Protection Agency does not permit the subtraction of blank results in Environmental Protection Agency-regulated analyses.

blind blank - Sample container of deionized water sent to a laboratory under an alias name as a quality control check.

blind replicate - In the Environmental Services Section groundwater monitoring program, a second sample taken from the same well at the same time as the primary sample, assigned an alias well name, and sent to a laboratory for analysis (as an unknown to the analyst).

blind sample - Control sample of known concentration in which the expected values of the constituent are unknown to the analyst

C calibration - Process of applying correction factors to equate a measurement to a known standard. Generally, a documented measurement control program of charts, graphs, and data that demonstrate that an instrument is properly calibrated.

Carolina bay - Type of shallow depression commonly found on the coastal Carolina plains. Carolina bays are typically circular or oval. Some are wet or marshy, while others are dry.

Central Savannah River Area (CSRA) - Eighteencounty area in Georgia and South Carolina surrounding Augusta, Georgia. The Savannah River Site is included in the Central Savannah River Area. Counties are Richmond, Columbia, McDuffie, Burke, Emanuel, Glascock, Jenkins, Jefferson, Lincoln, Screven, Taliaferro, Warren, and Wilkes in Georgia and Aiken, Edgefield, Allendale, Barnwell, and McCormick in South Carolina.

chemical oxygen demand - Indicates the quantity of oxidizable materials present in a water and varies with water composition, concentrations of reagent, temperature, period of contact, and other factors.

chlorocarbons - Compounds of carbon and chlorine, or carbon, hydrogen, and chlorine, such as carbon tetrachloride, chloroform, tetrachloroethylene, etc. They are among the most significant and widespread environmental contaminants. Classified as hazard- ous wastes, chlorocarbons may have a tendency to cause detrimental effects, such as birth defects.

cleanup - Actions taken to deal with release or potential release of hazardous substances. This may mean complete removal of the substance; it also may mean stabilizing, containing, or otherwise treating the substance so that it does not affect human health or the environment.

Comprehensive Environmental Response, Compensation, and Liability Act (CERCLA)-reportable release - Release to the environment that exceeds reportable quantities as defined by the Comprehensive Environmental Response, Compensation, and Liability Act.

concentration - Amount of a substance contained in a unit volume or mass of a sample.

conductivity - Measure of water's capacity to convey an electric current. This property is related to the total concentration of the ionized substances in a water and the temperature at which the measurement is made.

contamination - State of being made impure or unsuitable by contact or mixture with something unclean, bad, etc.

count - Signal that announces an ionization event within a counter; a measure of the radiation from an object or device.

counting geometry - Well-defined sample size and shape for which a counting system has been calibrated.

criteria pollutant - Any of the pollutants commonly used as indices for air quality that can have a serious effect on human health and the environment, including sulfur dioxide, nitrogen dioxide, total suspended particulates, PM10, carbon monoxide, ozone, gaseous fluorides, and lead.

curie - Unit of radioactivity. One curie is defined as $3.7 \times 1010$ (37 billion) disintegrations per second. Several fractions and multiples of the curie are commonly used:

kilocurie (kCi) - $103 \mathrm{Ci}$, one thousand curies; $3.7 \mathrm{x}$ 1013 disintegrations per second.

millicurie (mCi) - 10-3 Ci, one-thousandth of a curie; 3.7 x 107 disintegrations per second. 
microcurie $(\mu \mathrm{Ci})$ - 10-6 Ci, one-millionth of a curie; 3.7 x 104 disintegrations per second.

picocurie (pCi) - 10-12 Ci, one-trillionth of a curie; 0.037 disintegrations per second.

closure - Control of a hazardous waste management facility under Resource Conservation and Recovery Act requirements.

compliance - Fulfillment of applicable requirements of a plan or schedule ordered or approved by government authority.

composite - A blend of more than one portion to be used as a sample for analysis.

Comprehensive Environmental Response, Compensation, and Liability Act (CERCLA) - This act addresses the cleanup of hazardous substances and establishes a National Priority List of sites targeted for assessment and, if necessary, restoration (commonly known as "Superfund").

D decay (radioactive) - Spontaneous transformation of one radionuclide into a different radioactive or nonradioactive nuclide, or into a different energy state of the same radionuclide.

decay time - Time taken by a quantity to decay to a stated fraction of its initial value.

deactivation - The process of placing a facility in a stable and known condition, including the removal of hazardous and radioactive materials to ensure adequate protection of the worker, public health and safety, and the environment - thereby limiting the long-term cost of surveillance and maintenance.

decommissioning - Process that takes place after deactivation and includes surveillance and maintenance, decontamination, and/or dismantlement.

decontamination - The removal or reduction of residual radioactive and hazardous materials by mechanical, chemical, or other techniques to achieve a stated objective or end condition.

decommissioning and demolition - Program that reduces the environmental and safety risks of surplus facilities at SRS.

derived concentration guide - Concentration of a radionuclide in air or water that, under conditions of continuous exposure for one year by one exposure mode (i.e., ingestion of water, submersion in air, or inhalation), would result in either an effective dose equivalent of $0.1 \mathrm{rem}(1 \mathrm{mSv})$ or a dose equivalent of $5 \mathrm{rem}(50 \mathrm{mSv})$ to any tissue, including skin and lens of the eye. The guides for radionuclides in air and water are given in U.S. Department of Energy Order 5400.5 .

detection limit - See analytical detection limit, lower limit of detection, minimum detectable concentration.

detector - Material or device (instrument) that is sensitive to radiation and can produce a signal suitable for measurement or analysis.

diatometer - Diatom collection equipment consisting of a series of microscope slides in a holder that is used to determine the amount of algae in a water system.

diatoms - Unicellular or colonial algae of the class Bacillariophyceae, having siliceous cell walls with two overlapping, symmetrical parts. Diatoms represent the predominant periphyton (attached algae) in most water bodies and have been shown to be reliable indicators of water quality.

disposal - Permanent or temporary transfer of U.S. Department of Energy control and custody of real property to a third party, which thereby acquires rights to control, use, or relinquish the property.

disposition - Those activities that follow completion of program mission-including, but not limited to, surveillance and maintenance, deactivation, and decommissioning.

dissolved oxygen - Desirable indicator of satisfactory water quality in terms of low residuals of biologically available organic materials. Dissolved oxygen prevents the chemical reduction and subsequent leaching of iron and manganese from sediments.

dose - Energy imparted to matter by ionizing radiation. The unit of absorbed dose is the rad, equal to 0.01 joules per kilogram in any medium.

absorbed dose - Quantity of radiation energy absorbed by an organ, divided by the organ's mass. Absorbed dose is expressed in units of $\mathrm{rad}$ (or gray) $(1 \mathrm{rad}=0.01 \mathrm{~Gy})$. 
dose equivalent - Product of the absorbed dose (rad) in tissue and a quality factor. Dose equivalent is expressed in units of rem (or sievert) (1 rem $=0.01$ sievert).

committed dose equivalent - Calculated total dose equivalent to a tissue or organ over a 50-year period after known intake of a radionuclide into the body. Contributions from external dose are not included. Committed dose equivalent is expressed in units of rem (or sievert).

committed effective dose equivalent - Sum of the committed dose equivalents to various tissues in the body, each multiplied by the appropriate weighting factor. Committed effective dose equivalent is expressed in units of rem (or sievert).

effective dose equivalent - Sum of the dose equivalents received by all organs or tissues of the body after each one has been multiplied by an appropriate weighting factor. The effective dose equivalent includes the committed effective dose equivalent from internal deposition of radionuclides and the effective dose equivalent attributable to sources external to the body.

collective dose equivalent/collective effective dose equivalent - Sums of the dose equivalents or effective dose equivalents of all individuals in an exposed population within a $50-$ mile $(80-\mathrm{km})$ radius, and expressed in units of person-rem (or person-sievert). When the collective dose equivalent of interest is for a specific organ, the units would be organ-rem (or organ-sievert). The 50 -mile distance is measured from a point located centrally with respect to major facilities or U.S. Department of Energy program activities.

dosimeter - Portable detection device for measuring the total accumulated exposure to ionizing radiation.

downgradient - In the direction of decreasing hydrostatic head.

drinking water standards - Federal primary drinking water standards, both proposed and final, as set forth by the U.S. Environmental Protection Agency.

duplicate result - Result derived by taking a portion of a primary sample and performing the identical analysis on that portion as is performed on the primary sample. effluent - Any treated or untreated air emission or liquid discharge to the environment.

$\mathbf{E}$ effluent monitoring - Collection and analysis of samples or measurements of liquid and gaseous effluents for purpose of characterizing and quantifying the release of contaminants, assessing radiation exposures of members to the public, and demonstrating compliance with applicable standards.

environmental compliance - Actions taken in accordance with government laws, regulations, orders, etc., that apply to site operations' effects on onsite and offsite natural resources and on human health; used interchangeably in this document with regulatory compliance.

environmental monitoring - Program at Savannah River Site that includes effluent monitoring and environmental surveillance with dual purpose of (1) showing compliance with federal, state, and local regulations, as well as with U.S. Department of Energy orders, and (2) monitoring any effects of site operations on onsite and offsite natural resources and on human health.

environmental restoration - U.S. Department of Energy program that directs the assessment and cleanup of inactive waste units and groundwater (remediation) contaminated as a result of nuclearrelated activities.

environmental surveillance - Collection and analysis of samples of air, water, soil, foodstuffs, biota, and other media from U.S. Department of Energy sites and their environs and the measurement of external radiation for purpose of demonstrating compliance with applicable standards, assessing radiation exposures to members of the public, and assessing effects, if any, on the local environment.

exceedance - Term used by the U.S. Environmental Protection Agency and the South Carolina Department of Health and Environmental Control that denotes a report value is more than the upper guide limit. This term is found on the discharge monitoring report forms that are submitted to the Environmental Protection Agency or the South Carolina Department of Health and Environmental Control.

exposure (radiation) - Incidence of radiation on living or inanimate material by accident or intent. Background exposure is the exposure to natural back- 
ground ionizing radiation. Occupational exposure is the exposure to ionizing radiation that takes place during a person's working hours. Population exposure is the exposure to the total number of persons who inhabit an area.

exposure pathway - Route that materials follow to get to the environment and then to people.

fallout - See worldwide fallout.

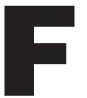

Federal Facility Agreement (FFA) - Agreement negotiated among the U.S. Department of Energy, the U.S. Environmental Protection Agency, and the South Carolina Department of Health and Environmental Control, specifying how the Savannah River Site will address contamination or potential contamination to meet regulatory requirements at site waste units identified for evaluation and, if necessary, cleanup.

feral hog - Hog that has reverted to the wild state from domestication.

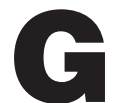
gamma ray - High-energy, short-wavelength electromagnetic radiation emitted from the nucleus of an excited atom. Gamma rays are identical to X-rays except for the source of the emission.

gamma-emitter - Any nuclide that emits a gamma ray during the process of radioactive decay. Generally, the fission products produced in nuclear reactors.

gamma spectrometry - System consisting of a detector, associated electronics, and a multichannel analyzer that is used to analyze samples for gammaemitting radionuclides.

grab sample - Sample collected instantaneously with a glass or plastic bottle placed below the water surface to collect surface water samples (also called dip samples).

$\mathbf{H}$ half-life (radiological) - Time required for half of a given number of atoms of a specific radionuclide to decay. Each nuclide has a unique half-life.

heavy water - Water in which the molecules contain oxygen and deuterium, an isotope of hydrogen that is heavier than ordinary hydrogen. hydraulic gradient - Difference in hydraulic head over a specified distance.

hydrology - Science that treats the occurrence, circulation, distribution, and properties of the waters of the earth, and their reaction with the environment.

in situ - In its original place. Field measurements taken without removing the sample from its origin; remediation performed while groundwater remains below the surface.

inorganic - Involving matter other than plant or animal.

instrument background - Instrument signal due to electrical noise and other interferences not attributed to the sample or blank.

ion exchange - Process in which a solution containing soluble ions is passed over a solid ion exchange column that removes the soluble ions by exchanging them with labile ions from the column's surface. Process is reversible so that trapped ions are removed (eluted) from column and column is regenerated.

irradiation - Exposure to radiation.

isotopes - Forms of an element having the same number of protons in their nuclei but differing in the number of neutrons.

long-lived isotope - Radionuclide that decays at such a slow rate that a quantity of it will exist for an extended period (half-life greater than three years).

short-lived isotope - Radionuclide that decays so rapidly that a given quantity is transformed almost completely into decay products within a short period (half-life is two days or less).

$\mathbf{L}$ laboratory blank - Deionized water sample generated by the laboratory; a laboratory blank is analyzed with each batch of samples as an in-house check of analytical procedures. Also called an internal blank.

legacy - Anything handed down from the past; inheritance, as of nuclear waste. 
lower limit of detection - Smallest concentration/ amount of an analyte that can be reliably detected in a sample at a 95-percent confidence level.

M

macroinvertebrates - Size-based classifica-

tion used for a variety of insects and other small invertebrates; as defined by the U.S. Environmental Protection Agency, those organisms that are retained by a No. 30 (590-micron) U.S Standard Sieve.

macrophyte - A plant that can be observed with the naked eye.

manmade radiation - Radiation from sources such as consumer products, medical procedures, and nuclear industry.

maximally exposed individual - Hypothetical individual who remains in an uncontrolled area and would, when all potential routes of exposure from a facility's operations are considered, receive the greatest possible dose equivalent.

maximum contaminant level - The maximum allowable concentration of a drinking water contaminant as legislated through the Safe Drinking Water Act

mean relative difference - Percentage error based on statistical analysis.

mercury - Silver-white, liquid metal solidifying at $-38.9^{\circ} \mathrm{C}$ to form a tin-white, ductile, malleable mass. It is widely distributed in the environment and biologically is a nonessential or nonbeneficial element. Human poisoning due to this highly toxic element has been clinically recognized.

migration - Transfer or movement of a material through the air, soil, or groundwater.

minimum detectable concentration - Smallest amount or concentration of a radionuclide that can be distinguished in a sample by a given measurement system at a preselected counting time and at a given confidence level.

moderate - To reduce the excessiveness of; to act as a moderator.

moderator - Material, such as heavy water, used in a nuclear reactor to moderate or slow down neutrons from the high velocities at which they are created in the fission process. monitoring - Process whereby the quantity and quality of factors that can affect the environment and/or human health are measured periodically to regulate and control potential impacts.

$\mathbf{N}$ nonroutine radioactive release - Unplanned or nonscheduled release of radioactivity to the environment.

nuclide - Atom specified by its atomic weight, atomic number, and energy state. A radionuclide is a radioactive nuclide.

$\mathbf{0}$ opacity - The reduction in visibility of an object or background as viewed through the diameter of a plume.

organic - Of, relating to, or derived from living organisms (plant or animal).

outcrop - Place where groundwater is discharged to the surface. Springs, swamps, and beds of streams and rivers are the outcrops of the water table.

outfall - Point of discharge (e.g., drain or pipe) of wastewater or other effluents into a ditch, pond, or river.

$\mathbf{P}$ parameter - Analytical constituent; chemical compound(s) or property for which an analytical request may be submitted.

permeability - Physical property that describes the ease with which water may move through the pore spaces and cracks in a solid.

person-rem - Collective dose to a population group. For example, a dose of one rem to 10 individuals results in a collective dose of 10 person-rem.

pH - Measure of the hydrogen ion concentration in an aqueous solution. Acidic solutions have a $\mathrm{pH}$ from 0 to 6 , basic solutions have a $\mathrm{pH}>7$, and neutral solutions have a $\mathrm{pH}=7$.

piezometer - Instrument used to measure the potentiometric surface of the groundwater. Also, a well designed for this purpose.

plume - Volume of contaminated air or water originating at a point-source emission (e.g., a smokestack) or at a waste source (e.g., a hazardous waste disposal site). 
point source - Any defined source of emission to air or water such as a stack, air vent, pipe, channel, or passage to a water body.

population dose - See collective dose equivalent under dose.

process sewer - Pipe or drain, generally located underground, used to carry off process water and/or waste matter.

purge - To remove water prior to sampling, generally by pumping or bailing.

purge water - Water that has been removed prior to sampling; water that has been released to seepage basins to allow a significant part of tritium to decay before the water outcrops to surface streams and flows to the Savannah River.

Q quality assurance (QA) - In the Environmental Monitoring System program, QA consists of the system whereby the laboratory can assure clients and other outside entities, such as government agencies and accrediting bodies, that the laboratory is generating data of proven and known quality.

quality control (QC) - In the Environmental Monitoring System program, QC refers to those operations undertaken in the laboratory to ensure that the data produced are generated within known probability limits of accuracy and precision.

$\mathbf{R}$ rad - Unit of absorbed dose deposited in a volume of material.

radioactivity - Spontaneous emission of radiation, generally alpha or beta particles, or gamma rays, from the nucleus of an unstable isotope.

radioisotopes - Radioactive isotopes.

radionuclide - Unstable nuclide capable of spontaneous transformation into other nuclides by changing its nuclear configuration or energy level. This transformation is accompanied by the emission of photons or particles.

real-time instrumentation - Operation in which programmed responses to an event essentially are simultaneous to the event itself.

reforestation - Process of planting new trees on land once forested. regulatory compliance - Actions taken in accordance with government laws, regulations, orders, etc., that apply to Savannah River Site operations' effects on onsite and offsite natural resources and on human health; used interchangeably in this document with environmental compliance.

release - Any discharge to the environment. Environment is broadly defined as any water, land, or ambient air.

rem - Unit of dose equivalent (absorbed dose in rads $x$ the radiation quality factor). Dose equivalent frequently is reported in units of millirem (mrem), which is one-thousandth of a rem.

remediation - Assessment and cleanup of U.S. Department of Energy sites contaminated with waste as a result of past activities. See environmental restoration.

remediation design - Planning aspects of remediation, such as engineering characterization, sampling studies, data compilation, and determining a path forward for a waste site.

replicate - In the Environmental Services Section groundwater monitoring program, a second sample from the same well taken at the same time as the primary sample and sent to the same laboratory for analysis.

\section{Resource Conservation and Recovery Act (RCRA)} Federal legislation that regulates the transport, treatment, and disposal of solid and hazardous wastes. This act also requires corrective action for releases of hazardous waste at inactive waste units.

\section{Resource Conservation and Recovery Act (RCRA)} site - Solid waste management unit under Resource Conservation and Recovery Act regulation. See Resource Conservation and Recovery Act.

retention basin - Unlined basin used for emergency, temporary storage of potentially contaminated cooling water from chemical separations activities.

RFI/RI Program - RCRA Facility Investigation/ Remedial Investigation Program. At the Savannah River Site, the expansion of the RFI Program to include Comprehensive Environmental Response, Compensation, and Liability Act and hazardous substance regulations. 
routine radioactive release - Planned or scheduled release of radioactivity to the environment.

$\mathbf{S}$ seepage basin - Excavation that receives wastewater. Insoluble materials settle out on the floor of the basin and soluble materials seep with the water through the soil column, where they are removed partially by ion exchange with the soil. Construction may include dikes to prevent overflow or surface runoff.

sensitivity - Capability of methodology or instruments to discriminate between samples with differing concentrations or containing varying amounts of analyte.

settling basin - Temporary holding basin (excavation) that receives wastewater that subsequently is discharged.

sievert - The International System of Units (SI)derived unit of dose equivalent. It attempts to reflect the biological effects of radiation as opposed to the physical aspects, which are characterized by the absorbed dose, measured in gray. One sievert is equal to $100 \mathrm{rem}$.

site stream - Any natural stream on the Savannah River Site. Surface drainage of the site is via these streams to the Savannah River.

source - Point or object from which radiation or contamination emanates.

source check - Radioactive source (with a known amount of radioactivity) used to check the performance of the radiation detector instrument.

source term - Quantity of radioactivity (released in a set period of time) that is traceable to the starting point of an effluent stream or migration pathway.

spent nuclear fuel - Used fuel elements from reactors.

spike - Addition, to a blank sample, of a known amount of reference material containing the analyte of interest.

stable - Not radioactive or not easily decomposed or otherwise modified chemically.

stack - Vertical pipe or flue designed to exhaust airborne gases and suspended particulate matter. standard deviation - Indication of the dispersion of a set of results around their average.

stormwater runoff - Surface streams that appear after precipitation.

Superfund - See Comprehensive Environmental Response, Compensation, and Liability Act (CERCLA).

supernate - Portion of a liquid above settled materials in a tank or other vessel.

surface water - All water on the surface of the earth, as distinguished from groundwater.

\section{T} tank farm - Installation of interconnected underground tanks for storage of high-level radioactive liquid wastes.

temperature - Thermal state of a body, considered with its ability to communicate heat to other bodies.

thermoluminescent dosimeter (TLD) - Device used to measure external gamma radiation.

total dissolved solids - Dissolved solids and total dissolved solids are terms generally associated with freshwater systems; they consist of inorganic salts, small amounts of organic matter, and dissolved materials.

total phosphorus - May occasionally stimulate excessive or nuisance growths of algae and other aquatic plants when concentrations exceed $25 \mathrm{mg} / \mathrm{L}$ at the time of the spring turnover on a volume-weighted basis in lakes or reservoirs.

total suspended particulates - Refers to the concentration of particulates in suspension in the air, regardless of the nature, source, or size of the particulates.

transport pathway - Pathway by which a released contaminant is transported physically from its point of discharge to a point of potential exposure to humans. Typical transport pathways include the atmosphere, surface water, and groundwater.

transuranic waste - Solid radioactive waste containing primarily alpha-emitting elements heavier than uranium. 
trend - General drift, tendency, or pattern of a set of data plotted over time.

turbidity - Measure of the concentration of sediment or suspended particles in solution.

$\mathbf{U}$ unspecified alpha and beta emissions - The unidentified alpha and beta emissions that are determined at each effluent location by subtracting the sum of the individually measured alphaemitting (e.g., plutonium-239 and uranium-235) and beta-emitting (e.g., cesium-137 and strontium-90) radionuclides from the measured gross alpha and beta values, respectively.

$\mathbf{V}$ vitrify - Change into glass.

vitrification - Process of changing into glass.

volatile organic compounds - Broad range of organic compounds, commonly halogenated, that vaporize at ambient, or relatively low, temperatures (e.g., acetone, benzene, chloroform, methyl alcohol).

$\mathbf{W}$

waste management - The U.S. Department of Energy uses this term to refer to the safe, effective management of various kinds of nonhazardous, hazardous, and radioactive waste generated at Savannah River Site.

waste unit - An inactive area known to have received contamination or to have had a release to the environment. water table - Planar, underground surface beneath which earth materials, such as soil or rock, are saturated with water.

weighting factor - Value used to calculate dose equivalents. It is tissue specific and represents the fraction of the total health risk resulting from uniform, whole-body irradiation that could be attributed to that particular tissue. The weighting factors used in this report are recommended by the International Commission on Radiological Protection (Publication 26).

wetland - Lowland area, such as a marsh or swamp, inundated or saturated by surface or groundwater sufficiently to support hydrophytic vegetation typically adapted for life in saturated soils.

wind rose - Diagram in which statistical information concerning wind direction and speed at a location is summarized.

worldwide fallout - Radioactive debris from atmospheric weapons tests that has been deposited on the earth's surface after being airborne and cycling around the earth. 



\section{References}

Aadland et al., 1995 Aadland, R.K., J.A. Gellici, and P.A. Thayer, 1995, "Hydrogeologic Framework of WestCentral South Carolina," Report 5, Water Resources Division, South Carolina Department of Natural Resources, Columbia, S.C.

Carlton et al., 1994 Carlton, W.H., C.E. Murphy, Jr., and A.G. Evans, 1994, "Radiocesium in the Savannah River Site Environment," Health Physics, Volume 67, Number 3, Williams \& Wilkins, Baltimore, Md.

Cherry, 2006 Cherry, G.S., 2006, "Simulation and Particle-Tracking Analysis of Ground-Water Flow near the Savannah River Site, Georgia and South Carolina, 2002, and for Selected Ground-Water Management Scenarios, 2002 and 2020," Scientific Investigations Report, 2006-5195, U.S. Geological Survey, Reston, Virginia.

Clarke and West, 1998 Clarke, J.S., and C.T. West, 1998, "Ground-Water Levels, Predevelopment Ground-Water Flow, and Stream-Aquifer Relations in the Vicinity of the Savannah River Site, Georgia and South Carolina," U.S. Geological Survey Water-Resources Investigations Report 974197, U.S. Geological Survey, Reston, Va.

DOE, 1988 U.S. Department of Energy, 1988, External and Internal Dose Conversion Factors for Calculation of Dose to the Public, DOE/EH-0070 \& 71, Washington, D.C.

DOE, 2002 U.S. Department of Energy, 2002, A Graded Approach for Evaluating Radiation Doses to Aquatic and Terrestrial Biota, DOE Standard, DOE-STD-1153-2002, July 2002, Washington, D.C.

EPA, 1989 U.S. Environmental Protection Agency, 1989, "National Priorities List for Uncontrolled Hazardous Waste Sites," Federal Register, Volume 54, Number 223, November 21, pp. 48184-48189, Washington, D.C.

EPA, 1999 U.S. Environmental Protection Agency, 1999, Cancer Risk Coefficients for Environmental Exposure to Radionuclides, Federal Guidance Report No.13, EPA 402-R-99-001, September 1999, Washington, D.C.

EPA, 2002 U.S. Environmental Protection Agency, 2002, "National Emission Standards for Hazardous Air Pollutants," Title 40 Code of Federal Regulations, Part 61, Subpart H, September 2002, Washington, D.C.

Fallaw and Price, 1995 Fallaw, W.C., and V. Price, 1995, "Stratigraphy of the Savannah River Site and Vicinity," Southeastern Geology, Vol. 35, No. 1, March 1995, pp. 21-58, Duke University, Durham, N.C.

FFA, 1993 Federal Facility Agreement for the Savannah River Site, 1993, Administrative Docket Number 89-05-FF, August 16, 1993, WSRC-OS-94-42, Savannah River Site, Aiken, S.C.

Fledderman, 2007 Fledderman, P.D., G.T. Jannik, and M.H. Paller, 2007, "An Overview of Cesium-137 Contamination in a Southeastern Swamp Environment," Operational Radiation Safety 93(3), pp. S160-S164, November 2007, Hagerstown, Md.

Hamby, 1991 Hamby, D.M., 1991, Land and Water Use Characteristics in the Vicinity of the Savannah River Site (U), WSRC-RP-91-17, Savannah River Site, Aiken, S.C. 
Hamby and Bauer, 1994 Hamby, D.M., and L.R. Bauer, 1994, "The Vegetation-to-Air Concentration Ratio in a Specific Activity Atmospheric Tritium Model," Health Physics, Volume 66, Number 3, Williams \& Wilkins, Baltimore, Md.

NRC, 1977 U.S. Nuclear Regulatory Commission, 1977, Regulatory Guide 1.109, Calculation of Annual Doses to Man from Routine Releases of Reactor Effluents for the Purpose of Evaluating Compliance with 10 CFR 50, Appendix I, Revision 1, Washington, D.C.

SCDHEC, 2008 South Carolina Department of Health and Environmental Control, 2008, "Water Classifications and Standards," South Carolina Code of Regulations, R.61-68, Columbia, S.C.

Smits et al., 1996 Smits, A.D., M.K. Harris, K.L. Hawkins, and G.P. Flach, 1996, "Integrated Hydrogeological Model of the General Separations Area, Volume 1: Hydrogeological Framework," WSRC-TR-96-0399, Revision 0, Westinghouse Savannah River Company, Aiken, S.C.

SRS EM Program, 2002 Savannah River Site Environmental Program, 2002, WSRC-3Q1-2, Volume 1, Revision 4, Section 1100, Savannah River Site, Aiken, S.C.

WSRC, 2008 Washington Savannah River Company, 2008, WSRC Quality Assurance Manual, WSRC-1Q, Savannah River Site, Aiken, SC.

Yu et al., 2001 C. Yu, A.J. Zielen, J.J. Cheng, D.J. LePoire, E. Gnanapragasam, S. Kamboj, Arnish, A. Wallo III, W.A. Williams, and H. Peterson, Users Manual for RESRAD Version 6, Argonne National Laboratory Report, ANL/EAD/4, July 2001, Argonne, Ill. 


\begin{tabular}{|c|c|c|c|}
\hline \multicolumn{2}{|c|}{ Units of Measure } & \multicolumn{2}{|c|}{ Units of Measure } \\
\hline Symbol & Name & Symbol & Name \\
\hline Temperature & & Concentration & \\
\hline${ }^{\circ} \mathrm{C}$ & degrees Centigrade & $\mathrm{ppb}$ & parts per billion \\
\hline${ }^{\circ} \mathrm{F}$ & degrees Fahrenheit & $\mathrm{ppm}$ & parts per million \\
\hline \multicolumn{4}{|l|}{ Time } \\
\hline$d$ & day & Rate & \\
\hline $\mathrm{h}$ & hour & cfs & cubic feet per second \\
\hline$y$ & year & gpm & gallons per minute \\
\hline \multicolumn{4}{|l|}{ Length } \\
\hline $\mathrm{cm}$ & centimeter & Conductivity & \\
\hline $\mathrm{ft}$ & foot & $\mu \mathrm{mho}$ & micromho \\
\hline in & inch & & \\
\hline $\mathrm{km}$ & kilometer & & \\
\hline $\mathrm{m}$ & meter & Radioactivity & \\
\hline $\mathrm{mm}$ & millimeter & $\mathrm{Ci}$ & curie \\
\hline \multirow[t]{2}{*}{$\mu \mathrm{m}$} & micrometer & $\mathrm{cpm}$ & counts per minute \\
\hline & & $\mathrm{mCi}$ & millicurie \\
\hline Mass & & $\mu \mathrm{Ci}$ & microcurie \\
\hline$g$ & gram & $\mathrm{pCi}$ & picocurie \\
\hline $\mathrm{kg}$ & kilogram & $\mathrm{Bq}$ & becquerel \\
\hline $\mathrm{mg}$ & milligram & & \\
\hline \multirow[t]{2}{*}{$\mu \mathrm{g}$} & microgram & & \\
\hline & & Radiation Dose & \\
\hline Area & & mrad & millirad \\
\hline $\mathrm{mi}^{2}$ & square mile & mrem & millirem \\
\hline \multirow[t]{2}{*}{$\mathrm{ft}^{2}$} & square foot & Sv & sievert \\
\hline & & $\mathrm{mSv}$ & millisievert \\
\hline Volume & & $\mu \mathrm{Sv}$ & microsievert \\
\hline gal & gallon & $\mathrm{R}$ & roentgen \\
\hline L & liter & $\mathrm{mR}$ & milliroentgen \\
\hline \multirow[t]{2}{*}{$\mathrm{mL}$} & milliliter & $\mu \mathrm{R}$ & microroentgen \\
\hline & & Gy & gray \\
\hline
\end{tabular}




\begin{tabular}{|lclll|}
\hline \multicolumn{5}{c}{ Fractions and Multiples of Units } \\
\hline Multiple & Decimal Equivalent & Prefix & Symbol & $\begin{array}{c}\text { Report } \\
\text { Format }\end{array}$ \\
\hline $10^{6}$ & $1,000,000$ & mega- & $\mathrm{M}$ & $\mathrm{E}+06$ \\
$10^{3}$ & 1,000 & kilo- & $\mathrm{k}$ & $\mathrm{E}+03$ \\
$10^{2}$ & 100 & hecto- & $\mathrm{h}$ & $\mathrm{E}+02$ \\
10 & 10 & deka- & $\mathrm{da}$ & $\mathrm{E}+01$ \\
$10^{-1}$ & 0.1 & deci- & $\mathrm{d}$ & $\mathrm{E}-01$ \\
$10^{-2}$ & 0.01 & centi- & $\mathrm{c}$ & $\mathrm{E}-02$ \\
$10^{-3}$ & 0.001 & milli- & $\mathrm{m}$ & $\mathrm{E}-03$ \\
$10^{-6}$ & 0.000001 & micro- & $\mu$ & $\mathrm{E}-06$ \\
$10^{-9}$ & 0.000000001 & nano- & $\mathrm{n}$ & $\mathrm{E}-09$ \\
$10^{-12}$ & 0.0000000000001 & pico- & $\mathrm{p}$ & $\mathrm{E}-12$ \\
$10^{-15}$ & 0.000000000000001 & femto- & $\mathrm{f}$ & $\mathrm{E}-15$ \\
$10^{-18}$ & 0.000000000000000001 & atto- & $\mathrm{a}$ & $\mathrm{E}-18$ \\
\hline
\end{tabular}

\begin{tabular}{|lll|}
\hline \multicolumn{3}{|c|}{ Conversion Table (Units of Radiation Measure) } \\
\hline Current System & Systéme International & Conversion \\
\hline curie (Ci) & becquerel $(\mathrm{Bq})$ & $1 \mathrm{Ci}=3.7 \times 10^{10} \mathrm{~Bq}$ \\
rad (radiation absorbed dose) & gray (Gy) & $1 \mathrm{rad}=0.01 \mathrm{~Gy}$ \\
rem (roentgen equivalent man) & sievert (Sv) & $1 \mathrm{rem}=0.01 \mathrm{~Sv}$ \\
\hline
\end{tabular}

\begin{tabular}{|lll|lcl|}
\hline \multicolumn{5}{c|}{ Conversion Table } \\
\hline Multiply & By & To Obtain & Multiply & By & To Obtain \\
\hline in. & 2.54 & $\mathrm{~cm}$ & $\mathrm{~cm}$ & 0.394 & $\mathrm{in}$. \\
$\mathrm{ft}$ & 0.305 & $\mathrm{~m}$ & $\mathrm{~m}$ & 3.28 & $\mathrm{ft}$ \\
$\mathrm{mi}$ & 1.61 & $\mathrm{~km}$ & $\mathrm{~km}$ & 0.621 & $\mathrm{mi}$ \\
$\mathrm{lb}$ & 0.4536 & $\mathrm{~kg}$ & $\mathrm{~kg}$ & 2.205 & $\mathrm{lb}$ \\
$\mathrm{liq} \mathrm{qt-U.S.}$ & 0.946 & $\mathrm{~L}$ & $\mathrm{~L}$ & 1.057 & $\mathrm{liq}$ qt-U.S. \\
$\mathrm{ft}^{2}$ & 0.093 & $\mathrm{~m}^{2}$ & $\mathrm{~m}^{2}$ & 10.764 & $\mathrm{ft}^{2}$ \\
$\mathrm{mi}^{2}$ & 2.59 & $\mathrm{~km}^{2}$ & $\mathrm{~km}$ & $\mathrm{mi}^{2}$ \\
$\mathrm{ft}^{3}$ & 0.028 & $\mathrm{~m}^{3}$ & $\mathrm{~m}^{3}$ & 0.386 & $\mathrm{ft}$ \\
$\mathrm{d} / \mathrm{m}$ & 0.450 & $\mathrm{pCi}$ & $\mathrm{pCi}$ & 35.31 & $\mathrm{~d} / \mathrm{m}$ \\
$\mathrm{pCi}$ & $10^{-6}$ & $\mu \mathrm{Ci}$ & $\mu \mathrm{Ci}$ & 2.22 & $\mathrm{pCi}$ \\
$\mathrm{pCi} / \mathrm{L}$ (water) & $10^{-9}$ & $\mu \mathrm{Ci} / \mathrm{mL}$ (water) & $\mu \mathrm{Ci} / \mathrm{mL}$ (water) & $10^{9}$ & $\mathrm{pCi} / \mathrm{L}$ (water) \\
$\mathrm{pCi} / \mathrm{m}^{3}$ (air) & $10^{-12}$ & $\mu \mathrm{Ci} / \mathrm{mL}$ (air) & $\mu \mathrm{Ci} / \mathrm{mL}$ (air) & $10^{12}$ & $\mathrm{pCi} / \mathrm{m}^{3}$ (air) \\
& & & & \\
\hline
\end{tabular}

